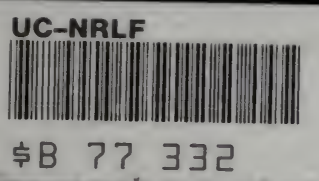



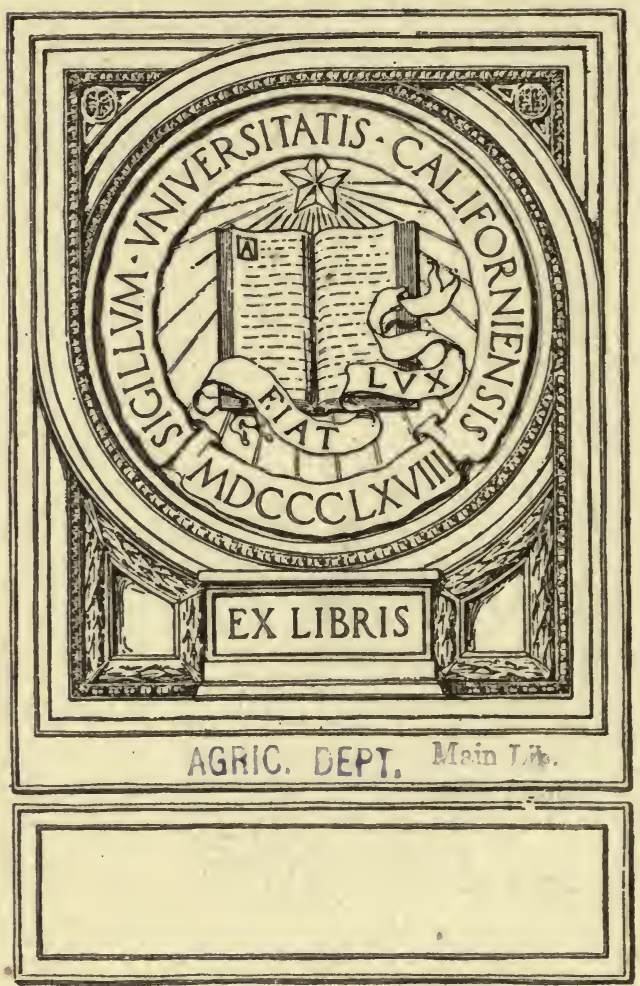

Digitized by the Internet Archive in 2007 with funding from Microsoft Corporation 




\section{- Eaa}

THE OREGON FARMER

WHAT HE HAS ACCOMPLISHED IN EVERY

PART OF THE STATE

A Preliminary Agricultural Survey Under the

Direction of an Advisory Committee

From the Faculty of

Oregon Agricultural College

Conducted by

Oregon Statistical Bureau

J. A. BEXELL, Director

E. B. Lemon, Assistant Statistician

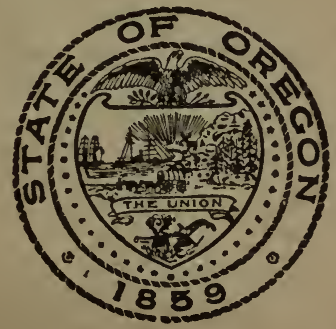

1913

Published by

Oregon State Immigration Commission

c. C. CHAPMAN

State Immigration Agent

PORTLAND, OREGON 
List of publications of Oregon Immigration Commission: THE OREGON FARMER: 136 pages telling what the average farmer has accomplished in every County of the State.

OREGON ALMANAC: 144 pages giving statistics of area, agricultural industry, opportunity and detailed description with maps of every County and district in Oregon.

OREGON ALBUM: 144 pages. Nearly 200 views of farms in every County of Oregon.

IMIMIGRANTS' GUIDE: 96 pages. Hand-book published in German.

ANNUAL REPORT: 16 pages indicating purposes and methods of Immigration Commission.

\section{Address :}

Oregon State Immigration Office

Commercial Club Building

Portland, Oregon 


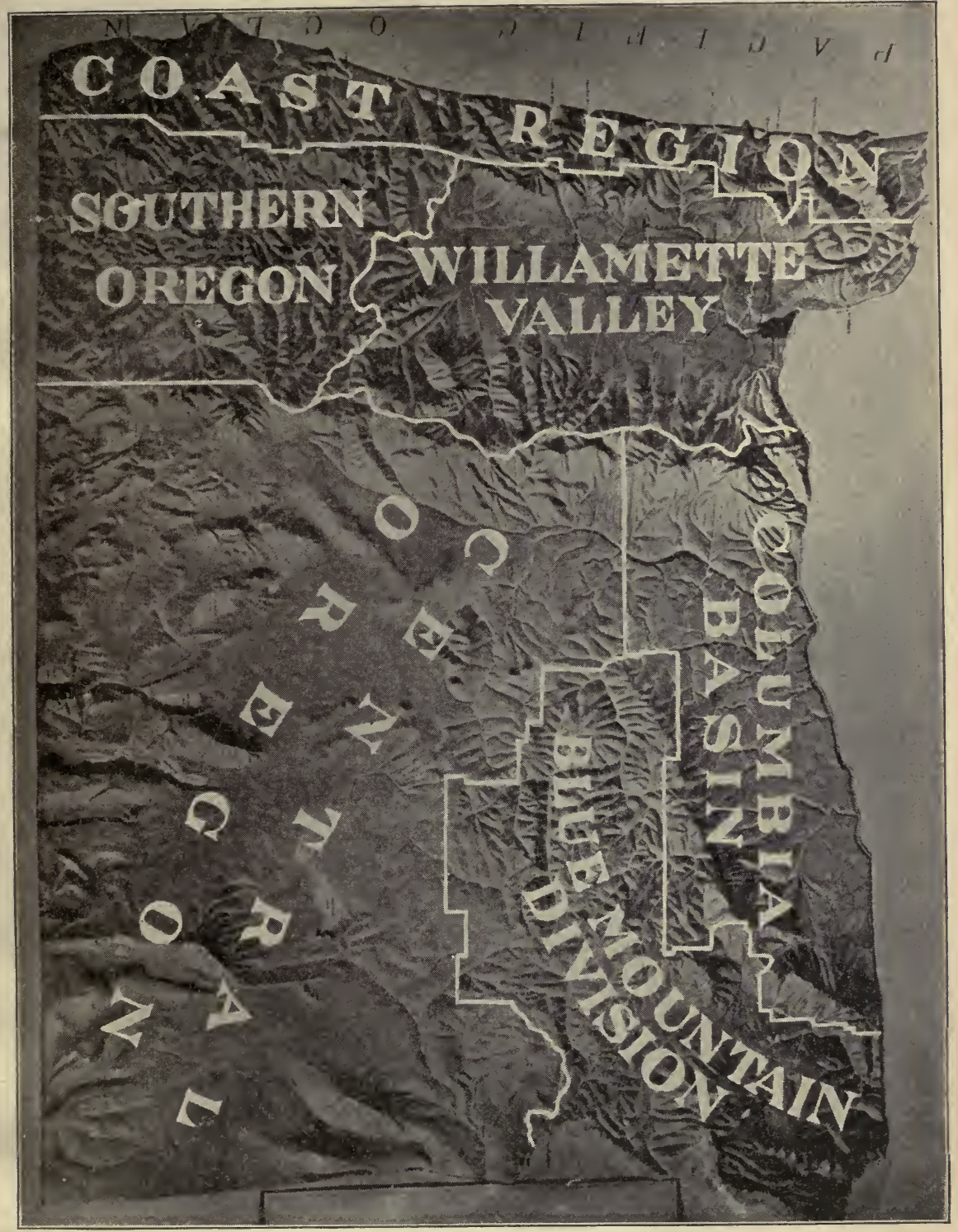

The climate of the State of Oregon is widely varied as between the six geographical subdivisions, governed by the physical conditions as shown in the accompanying topographic map, and embraces all of the desirable elements necessary for successful agricultural development, from the humid region along the Pacific Coast to the high and semi-arid plateau region of Central Oregon. The mountainous regions are covered with a dense growth of merchantable timber and perform the highly important double function of serving as immense water sheds and Nature's storehouse for millions of tons of Winter snows to supply the needed moisture for the broad and fertile valleys during the Summer months. 



\title{
THE OREGON FARMER
}

WHAT HE HAS ACCOMPLISHED IN EVERY PART OF THE STATE

\author{
A Preliminary Agricultural Survey Under the \\ Direction of an Advisory Committee \\ From the Faculty of \\ Oregon Agricultural College \\ CORVALLIS
}

\author{
Conducted by \\ Oregon Statistical Bureau \\ J. A. BEXELL, Director \\ E. B. Lemon, Assistant Statistician
}

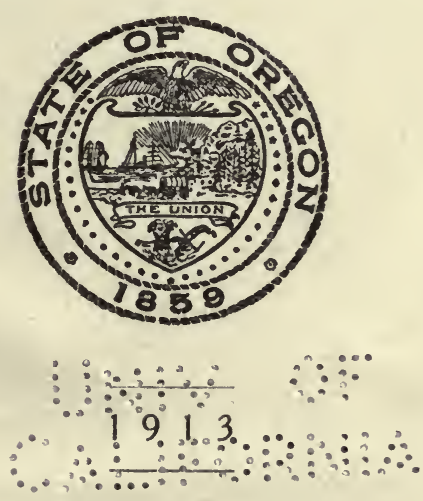

\section{Published by}

Oregon State Immigration Commission

C. C. CHAPMAN

State Immigration Agent

PORTLAND, OREGON 


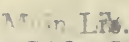 \\ AGRIC. DEPT. \\ CONTTNTS.}

Study this Book

C. C. Chapman

Page.

Introduction.

A. B. Cordley.

3

5

Agricultural Opportunities James Withycombe............ 13

The Live Stock Industry....E. L. Potter ................. 15

The Dairy Industry. ....... I. I. Kent................. $\quad 25$

Soils and Farm Crops .......H. D. Scuddor............... 33

The Climate of Oregon......W. L. Powers. .............. 65

Fruits and Vegetables......C. I. Lowis................. 71

The Poultry Industry..... James Dryden.............. $\quad 85$

Bee Culture................ F. Wilson................ 95

Farm Finance............J. A. Bexell................ 99

Country Life in Oregon .....Hector Macpherson........... 109

The Oregon Rural Home....Henrietta Calvin .............. 121

Typical Successful Farms ...E. B. Lemon ................. $\quad 125$

\section{MAPS, CHARTS AND DIAGRAMS.}

\section{MAPS.}

Page.

Sectional of the State.

Topographic of the State..................... Insert Front Cover

Precipitation Map ................................... 64

Distribution of Beef Cattle............................ 15

Distribution of Swine................................. 17

Distribution of Horses ................................ 19

Distribution of Sheep................................ ${ }_{22}$

Value of Poultry Prodúcts. . . . . .

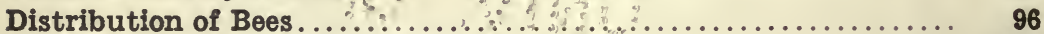

Distribution of Rural Populatinn ins...................... 114

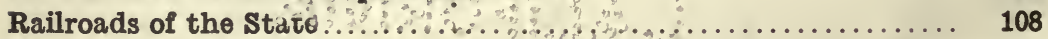

Educational Institutions............................... 118

DIAGRAMS.

Temperature and Precipitation......................... $\quad 69$

Showing Percentages of Investment....................... 98

Financing the Farm ..................................100

Land Area of State (a comparison) ..................... 114 


\section{STUDY THIS BOOK A.}

$63^{\text {LOWING reports telling of the wondrous success }}$ achieved by some one specialist in a new country, are of little value to the homeseeker of modest means.

What you and I and nearly all of us want to knowthe questions we want answered-are:

What has the average, serious, earnest, hard-working man accomplished? What kind of a home has he built for his family? How much money has he saved? What are his living conditions? What is his average income, year in and year out? What his expenses?

These are the common sense inquiries all of us make about the farmer in a new country. The traveler or tourist who is visiting Oregon, can get these answers for himself by stopping at each farm house and asking the questions. The homeseeker, however, often cannot afford to spend a lot of time and money making a personal investigation. The State of Oregon feels a responsibility to the bona-fide homeseeker. The responsibility of placing the facts before him just as clearly and plainly as they can be presented on paper in an official report.

This book has the facts in it,- - the averages as to what the average industrious man has accomplished here in the State of Oregon.

A corps of trained workers, investigators, was sent out by the State, into every County to interview farmers in every district. A list of questions was asked; these questions including nearly everything that a homeseeker would ask or would like to know as to what the average farmer had actually done since establishing himself in the State of Oregon. These answers were all tabulated and classified by expert statisticians, and have been analyzed by the practical men at the heads of the different bureaus or departments of our State Agricultural College. Every investigator and every department chief 
who had any part in the production of this book felt a deep sense of responsibility. Many of these men have devoted the better part of their lives to the service of the State of Oregon in its Agricultural College. Painstaking attention to detail and high devotion to the purpose to be served by this report, have characterized their work.

The facts are here and speak for themselves. While they indicate an amazing record of success and widespread prosperity on the part of the farmer-while they show that the Oregon farmer on an average is about as independent and well-fixed as the average of any class of people anywhere in the world-it is not the purpose of this book to invite anyone to come to Oregon or to argue as to the comparative merits of this and any other State. We simply feel that the homeseeker is entitled to the facts, and here they are.

Do not try to read this book continuously from beginning to end. Consult the sections in which you are most interested and analyze the statistics for yourself, a little at a time. Study the tables and read the explanations. It is hard to assimilate a vast accumulation of facts at a glance, or at one reading. This book will richly repay the most careful attention and study from the homeseeker who looks towards Oregon as a possible land of opportunity.

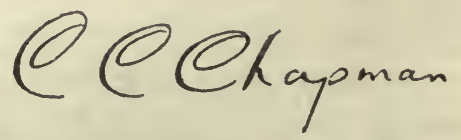

Oregon State Immigration Agent. 


\title{
INTRODUCTION
}

\section{OBJECT AND SCOPE OF THE SURVEY}

\author{
By A. B. Cordley
}

Dean of School of Agriculture

2 HE agricultural survey, of which this bulletin is a summary, was undertaken primarily for the purpose, not of adding to a knowledge of rural economics or sociology, but to obtain definite information of agricultural conditions in Oregon for the benefit of prospective settlers.

Oregon, with an area greater than that of Illinois and Indiana or of New York and Pennsylvania and with a population scarcely equal to that of Boston or St. Louis, has less than one-fifth of its tillable land under cultivation. Development of the latent wealth of the remainder, with its resultant effect upon the entire State, thus waits on immigration. Knowledge of the opportunities thus afforded, together with definite and accurate information of what Oregon farmers are now doing on these lands, should serve to attract the attention both of investors and settlers. The object of the survey was to obtain such information; the purpose of this bulletin is to present the information thus obtained in a plain statement of facts without the glittering generalities of the average advertising pamphlet.

Provision for this work was made by the Twenty-Sixth Legislative Assembly by an appropriation of $\$ 5,000$ for statistical research by the Bureau of Statistics in connection with the publicity work of the State Immigration Commission.

The Bureau of Statistics was organized by the appointment of Dean Bexell of the School of Commerce as Director, E. B. Lemon as Assistant Statistician, Neil B. Baldwin as Office Assistant, and the following advisory committee:

J. A. Bexell, Dean School of Commerce (Ex-Officio).

James Withycombe, Director of the Oregon Experiment Station.

A. B. Cordley, Dean of Agriculture.

G. A. Covell, Dean of Engineering.

Henrietta W. Calvin, Dean of Domestic Science and Art.

C. I. Lewis, Professor of Horticulture.

H. D. Scudder, Professor of Agronomy.

F. L. Kent, Professor of Dairy Husbandry.

E. L. Potter, Professor of Animal Husbandry.

James Dryden, Professor of Poultry Husbandry.

H. M. Parks, Professor of Mining Engineering.

G. W. Peavy, Professor of Forestry.

Hector Macpherson, Assistant Professor of Political Economy.

This committee met with the State Immigration Agent, C. C. Chapman, May 18, 1912, and perfected tentative plans for the work, and again on October 28,1912, when it was decided to co-operate 
with the State Immigration Commission and the State Immigration Agent in publishing this digest of the survey in an edition of 25,000 copies. Professors Cordley, Lewis and Bexell were appointed as an editing committee. The total cost of the survey, including the tabulation of the report and the preparation of the copy for this bulietin, but not including the cost of publication, was $\$ 3,900.11$. (See Annual Report of Oregon State Immigration Commission, 1912.) That so much has been accomplished at such slight expense is due in no little degree to the various railroad companies of the State who generously furnished transportation over their respective lines for all men engaged in this work.

The scope of the work is well indicated by the following letter which was sent out to a large number of citizens in various parts of the State:

"Dear Sir:

"The Oregon Statistical Bureau, in co-operation with the Agricultural College, is making a preliminary agricultural survey of a number of leading farms in every county in the State. The object of this survey is primarily to determine the opportunities in each locality for new settlers and, if possible, to find some of the difficulties in agricultural development.

"A number of farms in your locality will be visited during the summer by $\mathrm{Mr}_{\mathrm{A}}$. Such questions as the following will be asked: The value of land, machinery, stock on hand June 1; the acreage and yield of each crop in 1911; the amount of these crops sold and the receipts; the amount of other farm products, such as milk, butter, eggs, fruit, etc., sold during the year, and the receipts; the expenses for labor, seed, feed, fertilizer, machinery, threshing, etc.; the methods of cultivation used and your observation of the results.

"As your answer will be used for the benefit of your community and of the entire State, accuracy of statement is of the utmost importance. All of the informatiou received from you and your neighbors will be compiled in making up a final report on the general conditions in your community. Your statement will be considered strictly confidential. The reports of individuals will not be published without their consent.

"We hope that the farmers will assist our representatives in securing the information desired and that in turn the College and the Immigration Commission may aid the farmers by giving advice to all those who wish it."

During the preliminary discussions regarding the scope of the survey it soon became evident that a number of separate questionnaires would be necessary in order to accumulate the desired information relative to the various types of farming. The preparation of these was assigned to the various members of the advisory committee, under the general supervision of the Director, who edited and published them in pamphlet form for the use of the field agents. The field work began June 17, 1912, and was prosecuted vigorously until October. Upon receipt of the earlier reports, the work of tabulation was begun in order to detect and correct any possible errors that might be made by any of the agents at the earliest possible moment. All data as it came in was tabulated first by counties and then by districts. When all the reports had been received and tabulated the information thus accumulated was referred to the 
Geographically the state is divided into two sections, commonly known as Eastern and Western Oregon. Climatologically it is sub-divided into five sections (indicated by the heavy boundary lines on the map, outlining each sub-division) in which a wide variety of climatic conditions prevail to meet the requirements of every branch of agricultural pursuit and the demands of the individual resident from the standpoint of healtp and comfort.

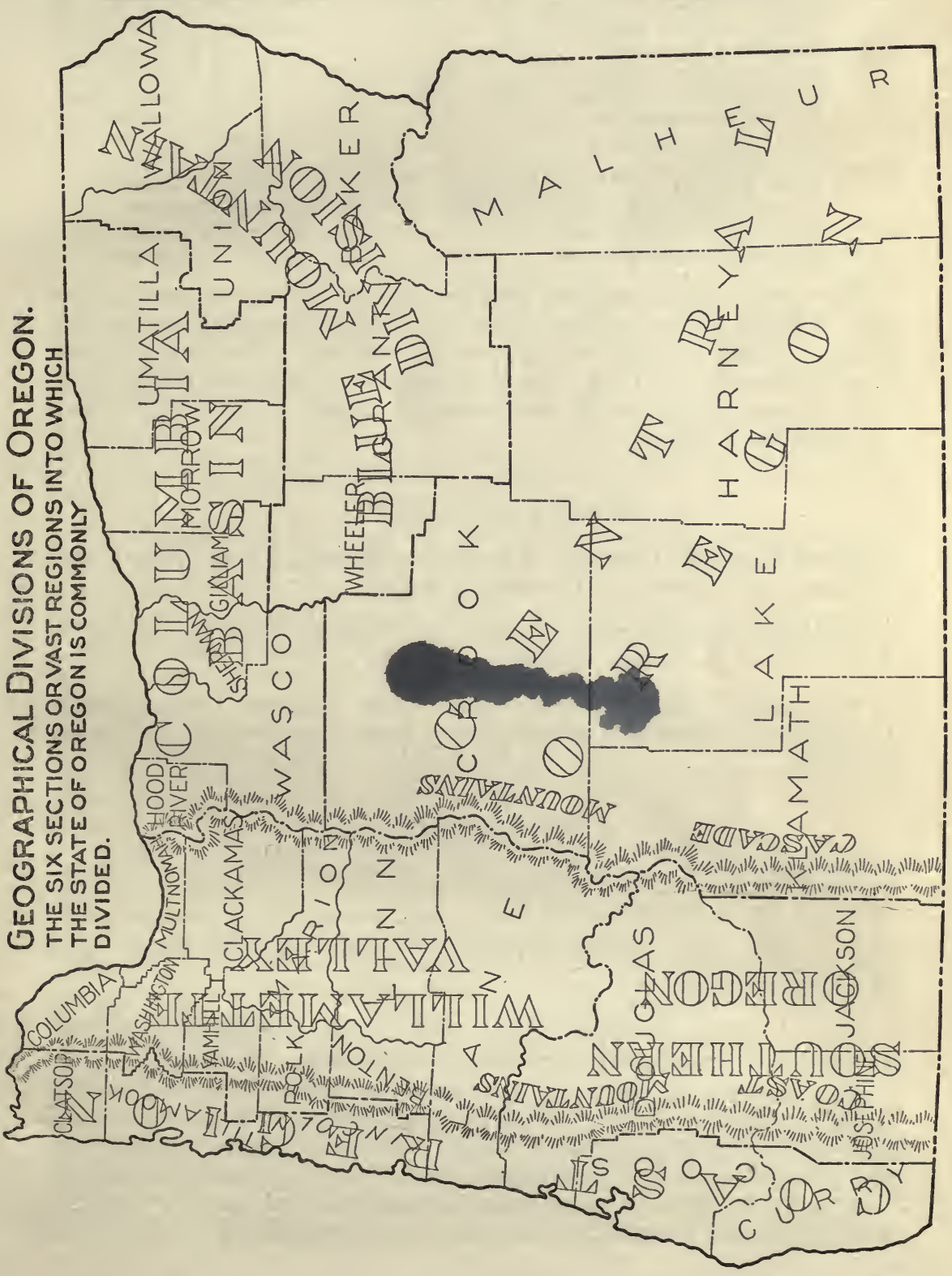


various members of the advisory committee to be used in the preparation of their respective reports. Thus all data relative to the live stock industry was referred to Professor Potter; that which related to horticulture, to Professor Lewis, etc., and upon this data their respective papers were based. They are as follows:

Agricultural Opportunities.................James Withycombe

The Live Stock Industry ...................... L. Potter

The Dairy Industry................................... Kent

Soils and Farm Crops........................ D. Scudder

The Climate of Oregon....................... I. Powers

Fruits and Vegetables....................................

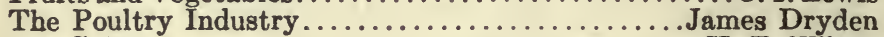

Bee Culture............................. F. Wilson

Farm Finance................................ Bexell

Country Life in Oregon................. Hector Macpherson

The Oregon Rural Home..................Henrietta Calvin

Typical Successful Farms................... B. Lemon

For comparative purposes and for convenience in tabulating the data relative to the various types of farming, the information was grouped first by counties and then by districts. The State divides itself naturally into two great divisions as regards topography, soil, climate and state of development, namely: Western Oregon and Eastern Oregon.

\section{WESTERN OREGON.}

Coast Division-Clatsop, Tillamook, Lincoln, Coos, Curry, part of Lane, and part of of Douglas counties.

Southern Oregon Division (Rogue and Umpqua Valleys)-Douglas, Jackson and Josephine counties.

Willamette Valley Division-Linn, Lane, Benton, Polk, Marion, Clackamas, Yamhill, Washington, Multnomah and Columbia counties.

\section{EASTERN OREGON.}

Columbia Basin Division-Hood River, Wasco, Sherman, Gilliam, Morrow and Umatilla counties.

Blue Mountain Division-Wheeler, Grant, Baker, Union, and Wallowa counties.

Central Oregon Division-That vast empire embraced in Crook, Klamath, Lake, Harney, and Malheur counties.

For purposes of more just and accurate comparisons the reports from the various districts were grouped according to size of farms as indicated in the following table. This is evidently necessary as the results obtained by extensive methods on the larger farms are not justly comparable with those obtained by the more intensive methods which are usually practiced on the smaller ones. 
CLASSIFICATION OF REPORTS.

\begin{tabular}{|c|c|c|c|c|c|c|}
\hline Division & $\underset{\text { reports. }}{5-20}$ & $\begin{array}{l}21-80 \\
\text { reports. }\end{array}$ & $\begin{array}{l}81-160 \\
\text { repes-ports. }\end{array}$ & $\begin{array}{l}161-320 \\
\text { acres-ports. }\end{array}$ & $\begin{array}{l}\text { 321-over } \\
\text { acres- } \\
\text { reports. }\end{array}$ & $\begin{array}{c}\text { Total } \\
\text { reports. }\end{array}$ \\
\hline 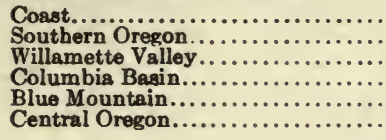 & $\begin{array}{r}6 \\
38 \\
36 \\
25 \\
13 \\
3\end{array}$ & $\begin{array}{r}24 \\
59 \\
152 \\
40 \\
12 \\
19\end{array}$ & $\begin{array}{r}56 \\
45 \\
137 \\
28 \\
16 \\
42\end{array}$ & $\begin{array}{r}55 \\
46 \\
129 \\
22 \\
35 \\
49\end{array}$ & $\begin{array}{r}35 \\
43 \\
102 \\
147 \\
125 \\
98\end{array}$ & $\begin{array}{l}175 \\
231 \\
556 \\
262 \\
201 \\
211\end{array}$ \\
\hline State... & 121 & 306 & 324 & 336 & 550 & 1,637 \\
\hline
\end{tabular}

TABLE SHOWING PERCENTAGE OF DIFFERENT TYPES OF FARMS EXAMINED IN THE AGRICULTURAL SURVEY.

\begin{tabular}{|c|c|c|c|c|c|c|c|}
\hline Division & $\begin{array}{l}\text { General } \\
\text { per cent. }\end{array}$ & $\begin{array}{c}\text { Hay } \\
\text { per cent. }\end{array}$ & $\begin{array}{c}\text { Grain } \\
\text { per cent. }\end{array}$ & $\begin{array}{c}\text { Stock } \\
\text { per cent. }\end{array}$ & $\begin{array}{c}\text { Dairy } \\
\text { per cent. }\end{array}$ & $\begin{array}{c}\text { Fruit } \\
\text { per cent. }\end{array}$ & $\begin{array}{c}\text { Truck } \\
\text { per cent. }\end{array}$ \\
\hline 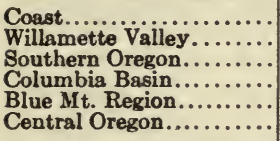 & $\begin{array}{l}12.0 \\
46.0 \\
29.0 \\
17.0 \\
18.0 \\
46.0\end{array}$ & $\begin{array}{r}\ddot{2.0} \\
9.0 \\
8.0 \\
8.6 \\
3.8\end{array}$ & $\begin{array}{r}1.2 \\
3.7 \\
6.0 \\
27.0 \\
6.5 \\
14.0\end{array}$ & $\begin{array}{r}20.2 \\
5.3 \\
9.3 \\
17.0 \\
50.3 \\
28.0\end{array}$ & $\begin{array}{r}66.0 \\
19.0 \\
11.0 \\
3.8 \\
3.3 \\
4.4\end{array}$ & $\begin{array}{r}0.6 \\
16.0 \\
25.0 \\
24.6^{*} \\
13.3 \\
1.9\end{array}$ & $\begin{array}{r}8.0 \\
10.7 \\
2.6 \\
1.9\end{array}$ \\
\hline State averages...... & 25.3 & 8.3 & 9.4 & 20.1 & 17.5 & 13.7 & 5.8 \\
\hline
\end{tabular}

"On account of the large number of fruit farms reported from Hood River County and Umatilla County.

Throughout the survey every effort was made to insure accuracy - the desire was to obtain facts and facts only. Every field agent was provided with the following letter of instruction and later as the work progressed each was repeatedly urged to exercise the greatest care to insure that each interview was as complete and accurate as it was possible to make it.

"Mr.

"The industrial survey which you are to assist in carrying out this summer is of the utmost importance to Oregon and her citizens. The statistics which you are to obtain, if they are painstakingly and honestly gathered, will aid materially in solving many of the agricultural problems of the State and to locate to the best advantage prospective settlers.

"Every one engaged in this work should aim to make every interview as complete and thorough as possible so that when the final results are published they will make the best showing for Oregon that the facts will justify. The facts, no more, no less, are wanted.

"Do not slight any feature of the questionnaire, but endeavor to secure each item. Negligence will materially lessen the value of the final results. Make it clear to every individual called upon that giving information you ask for has nothing whatever to do with assessment or taxation.

"It is impossible to lay down fixed rules for each solicitor since conditions differ materially in every locality. The following suggestions, however, will probably prove helpful:

"1. Interview the officers of the commercial club (or other organizationin places having no commercial club secure the co-operation of the banker, postmaster or other leading citizens) in the locality you are about to solicit and secure a list of representative and successful farmers to be interviewed. Bear in mind that what is wanted is data from successful farmers, under average conditions. 
"The principal questions are: On what have they succeeded, and why? From ten to twenty farmers will generally be sufficient in each locality. The minimum number to be interviewed in a county is fifty, and those should be scattered throughout the county. Do not make mistake of confining your attention to a popular and easily accessible locality, to the exclusion of localities less known, since the primary object of the survey is to find the opportunities open to settlers in every part of the county, and especially in those parts that are least developed.

"2. Send a form letter to each of the farmers selected. Be sure to fill in your name and date.

"3. Arrange your route so as to secure the greatest economy of time. The best results will be obtained by arranging to stop at farm houses over night, whenever practicable, since in this way you will save time and obtain considerable valuable information.

"4. Call on the newspapers of the town and introduce yourself by presenting a form letter and a questionnaire. Explain your mission and suggest that a mention will be appreciated.

"5. All interviews should be made on the farm, and your own impression as well as the specific information should be carefully noted. Whenever possible, secure the information from records and do not accept statements intended purely for local advertising. The object of this survey is to secure facts.

"6. It will often be found impracticable to fill out the entire list of questions in the presence of the farmer interviewed. All omissions, however, should be filled in completely before the interview is mailed.

“7. Until further notice, mail interviews every day if you are within mail connections. Remember that this requires first class postage. Keep this office informed of your plans and movements at all times.

"8. Expense vouchers must be fully itemized and a receipt taken for every item of one dollar and above. Forward expense bills to this office not later than the last day of each month.

"9. After completing the agricultural survey of a given locality, fill out and send in your private locality report. Whenever practicable it would be instructive to attend Sunday services in the country churches, and thus learn by your own observation something of their influence in the country.

"10. Farmers will frequently ask for professional information of great importance to themselves and their community. In most cases it is advisable that you refer such matters to the proper department of the College, and that you represent yourself only as a solicitor.

"11. Bear in mind particularly that while each field agent is sent into localities devoted principally to his own specialty, he is to complete the survey in each county before leaving it. That is, while interviews on the Hood River district, for instance, will be devoted very largely to fruit, yet there will be found very successful general farms, and these should be properly represented in the total number of interviews of the county, otherwise the survey will not show properly the range of opportunities in each county.

"12. For comparative purposes it is important that both the large and the small farms be about equally represented in the survey. Kindly bear this in mind in selecting the farms to be interviewed."

The active field work was done by thirteen agents, all of whom were senior or graduate students or members of the faculty of the Oregon Agricultural College; and each of whom was assigned to one or more counties, depending upon area and density of population. 


\section{FIELD AGENTS}

Mr. R. B. Thompson-Parts of Polk, Yamhill and Washington.

Mr. E. B. Stanley-Wheeler, Grant, Wallowa, and part of Umatilla.

Mr. F. R. Stockwell-Columbia, Clatsop, and Tillamook.

Dr. B. W. Hollis-Lincoln.

Mr. W. L. Powers-Part of Crook.

Mr. Walter E. Morris-Coos and Curry.

Mr. H. A. Morgenstern-Lake.

Mr. Morris Koon-Lane, Marion, and part of Linn.

Mr. Harry Hetzel-Union, Hood River, Multnomah, and parts of Wasco, Washington and Yamhill.

Mr. M. O. Evans, Jr.-Jackson, Josephine, Douglas, Clackamas, and parts of Polk, Linn and Benton.

Mr. E. W. Curtis-Harney, Klamath, and part of Crook.

Mr. Orren Beaty-Sherman, Morrow, and Gilliam.

Mr. E. B. Lemon-Parts of Benton and Wasco.

Acting under the above instructions these agents held the interviews for and filed a total of 1637 approved reports. The reports which were tabulated were distributed among the various counties as follows:

Baker 51, Benton 52, Clackamas 69, Clatsop 37, Columbia 45, Coos 33, Crook 48, Curry 19, Douglas 82, Gilliam 40, Grant 31, Harney 19, Hood River 27, Jackson 96, Josephine 53, Klamath 71, Lake 59, Lane 91, Lincoln 38, Linn 48, Marion 67, Malheur 15, Morrow 39, Multnomah 18, Polk 47, Sherman 41, Tillamook 49, Umatilla 63, Union 46, Wallowa 31, Wasco 52, Washington 65, Wheeler 42, Yamhill 54 .

It will be seen that the survey is an honest effort to represent the actual condition of country life in Oregon. Absolute accuracy is not claimed for the large mass of figures exhibited in the various tables. The reader is left largely to draw his own conclusions from the material at hand. In most cases, the number of reports is stated in connection with the averages, which indicates what confidence may be placed on the figures. That the averages are not far from the truth appears from a comparison with certain data found in the last census reports. For instance, Dean Bexell says in regard to the value of live stock: "The State averages are $\$ 341, \$ 878$, $\$ 1887, \$ 2255$, and $\$ 8030$, according to the several sizes of farms. These amounts are 3.6 per cent, 4.7 per cent, 8.2 per cent, 8.1 per cent, and 14.9 per cent of the respective total investments, as shown in the table on page 102 . When it is remembered that the large farms greatly predominate in the survey these ratios are confirmed by the last census, which places the value of live stock at 11.3 per cent of the total value of farm property." A more striking confirmation is found in the value of implements and machinery. The rates found in the survey are 2.4 per cent, 2.4 per cent, 2.3 per cent, 2.4 per cent, and 2.1 per cent, according to the different sizes of farms. The census finds the State average to be 2.5 per cent. In a survey of Tompkins County, New York, it was found that 45 per cent of the farmers based their reports on records, while in this survey 48 per cent make a similar claim. 
While the primary purpose of this bulletin is to furnish to prospective settlers information of what is actually being done by Oregon farmers, doubtless it also contains much that is of interest to these farmers themselves. However, it should undoubtedly be supplemented by further studies along similar lines. We now realize as never before that the rural problem is a problem of better business and better living as well as of better farming; but before much of value can be accomplished in solving the economic and social problems of the farm we shall have to recognize and act upon the idea that such problems offer as important a field for investigation as do those which relate merely to production. Definite information upon which to base improved methods of production became available only with the development of the research functions of the various State experiment stations, and it is evident, I think, that careful field studies of the factors involved must necessarily form the basis for any satisfactory solution of the social and economic problems of the open country. This work is so fundamental that I consider it most unfortunate that no provision has been made for continuing a line of investigation in which this bulletin represents the first step.

\section{Statistics Based on Averages.}

The tabulated statistics contained in this booklet are NOT based upon the average conditions prevailing generally throughout the state, but represent the AVERAGES based upon the number of reports received upon the different subjects, and the reader should not be misguided in this respect. It is not the purpose or intention to mislead the prospective homeseeker. Instances of unusual results are not cited in the composition of this booklet, but only the AVERAGES in all cases are taken into consideration so as to avoid all possibility of misrepresentation. Painstaking care has been exercised to present the conditions as they actually exist, in so far as the results of this survey are concerned, with the average farmer in the state. STATE AVERAGES represent the AVERAGE results taken from farms that were selected as representing average possibilities in each section. 


\section{AGRICULTURAL OPPORTUNITIES IN OREGON.}

By James Wrтhусомве

Director Experiment Station.

GENERAL STATISTICS (A)

\begin{tabular}{|c|c|c|c|c|c|c|c|c|c|}
\hline \multirow{3}{*}{ DIVISION } & \multirow{3}{*}{$\begin{array}{l}\text { Number } \\
\text { of } \\
\text { Reports }\end{array}$} & \multirow{3}{*}{$\begin{array}{c}\text { Average } \\
\text { Years on } \\
\text { this } \\
\text { Farm }\end{array}$} & \multirow{2}{*}{\multicolumn{2}{|c|}{$\begin{array}{l}\text { Years Ex- } \\
\text { perience as } \\
\text { Farmers. }\end{array}$}} & \multicolumn{5}{|c|}{ Average Acreage Operated. } \\
\hline & & & & & \multirow{2}{*}{$\begin{array}{l}\text { Total } \\
\text { Own- } \\
\text { ed. }\end{array}$} & \multirow{2}{*}{ Min. } & \multirow{2}{*}{ Max. } & \multirow{2}{*}{ Rent. } & \multirow{2}{*}{ Cultivated. } \\
\hline & & & Min. & Max. & & & & & \\
\hline 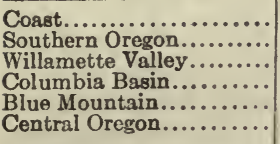 & $\begin{array}{l}176 \\
231 \\
555 \\
262 \\
201 \\
212\end{array}$ & $\begin{array}{l}12 \\
12 \\
15 \\
13 \\
13 \\
10\end{array}$ & $\begin{array}{l}1 \\
1 \\
1 \\
1 \\
1 \\
1\end{array}$ & $\begin{array}{l}42 \\
48 \\
57 \\
38 \\
34 \\
32\end{array}$ & $\begin{array}{r}250 \\
228 \\
178 \\
031 \\
1089 \\
548\end{array}$ & $\begin{array}{r}38 \\
3 \\
10 \\
35 \\
20 \\
33\end{array}$ & $\begin{array}{r}750 \\
2900 \\
866 \\
8220 \\
11280 \\
8350\end{array}$ & $\begin{array}{r}331 \\
156 \\
140 \\
1073 \\
1808 \\
396\end{array}$ & $\begin{array}{r}53 \\
70 \\
102 \\
414 \\
195 \\
165\end{array}$ \\
\hline STATE.............. & 1637 & 12 & 1 & 42 & 475 & 23 & 5394 & 651 & 149 \\
\hline
\end{tabular}

GENERAL STATISTICS (B)

\begin{tabular}{|c|c|c|c|c|c|c|c|}
\hline \multirow[t]{2}{*}{ DIVISION } & \multicolumn{2}{|c|}{$\begin{array}{c}\text { Required to } \\
\text { Operate Farm. }\end{array}$} & \multicolumn{3}{|c|}{$\begin{array}{l}\text { Number Reporting Good } \\
\text { Opportunities for Work. }\end{array}$} & \multirow{2}{*}{$\begin{array}{l}\text { Average } \\
\text { Depth of } \\
\text { Wells, } \\
\text { Feet. }\end{array}$} & \multirow{2}{*}{$\begin{array}{c}\text { Number of } \\
\text { Rural } \\
\text { Telephones. }\end{array}$} \\
\hline & Men & Horses. & $\begin{array}{c}\text { Carpen- } \\
\text { try. }\end{array}$ & Masonry. & $\begin{array}{c}\text { Black- } \\
\text { smithing. }\end{array}$ & & \\
\hline $\begin{array}{l}\text { Coast.................... } \\
\text { Southern Orregon....... } \\
\text { Willamette Valley...... } \\
\text { Columbia Basin ......... } \\
\text { Blue Mountain ......... } \\
\text { Central Oregon......... }\end{array}$ & $\begin{array}{r}3 \\
2 \\
11 \\
3 \\
3 \\
2\end{array}$ & $\begin{array}{r}4 \\
4 \\
4 \\
10 \\
8 \\
8\end{array}$ & $\begin{array}{r}29 \\
3 \\
142 \\
19 \\
37 \\
39\end{array}$ & $\begin{array}{r}20 \\
1 \\
38 \\
2 \\
13 \\
7\end{array}$ & $\begin{array}{r}41 \\
85 \\
190 \\
41 \\
32 \\
39\end{array}$ & $\begin{array}{l}22 \\
21 \\
36 \\
58 \\
23 \\
46\end{array}$ & $\begin{array}{l}137 \\
201 \\
500 \\
168 \\
153 \\
102\end{array}$ \\
\hline STATE........... & 4 & 7 & 269 & 81 & 428 & 34 & 1260 \\
\hline
\end{tabular}

(1)

REGON is a land of agricultural opportunities. The state is divided by the Cascade range of mountains into two grand physical divisions, known as Western and Eastern Oregon. The western division is a humid section and the eastern is mainly arid or semi-arid. These two sections of the state are subdivided by geographical, soil and climatic conditions into smaller divisions. In the western division, crop failure is unknown, and the same condition largely exists in the eastern section, where agriculture is not so well developed.

Much of Oregon is comparatively new in agriculture, nevertheless the industry is established upon a stable basis. Statistical data secured from 1637 farms show that the average time the present occupants have been in possession is twelve years. The range of occupancy of these 1637 farmers is from one to fifty-seven years. This average includes the newer settled portions of the state, thus showing there is no general unrest or pronounced land speculative tendencies among the farmers of Oregon.

Agricultural opportunities in Oregon are abundant. There are approximately 45,000 farmers in Oregon and the tillable agricultural area of the state is estimated at 23,000,000 acres. A considerable portion of this, however, at present is in forest, but after the forest 
will come the farms. The average size of an Oregon farm is 514 acres, but the average size of a farm in Western Oregon is only 112 acres. The general tendency in the humid and irrigated sections is toward smaller farms. In a number of sections, under intensive methods of crop production, farmers are making a good living from ten acres of ground.

Much of Oregon is a timbered country and a considerable area is used for pasture, thus while the average sized farm is 514 acres the average amount of cultivated land on each farm is 149 acres.

Another attractive feature of the average Oregon farm is the great abundance of good water. The greater portion of the state is well supplied with water from running streams. In addition to this, excellent water is within easy reach over a very large portion of the state. From the data secured from over 1600 farms, representing all sections of the state, the average depth of wells is shown to be 34 feet.

The farmers of Oregon are progressive, as shown by investments in farmstead improvements and the very general use of the telephone. Out of 1637 farmers interviewed 1260 reported having 'phones, or 77 per cent.

Farmers of Oregon are not only progressive but are also prosperous, judging from the amount of capital invested in farms, ranging from $\$ 7,150$ to $\$ 59,955$. The farmers also reside in good substantial homes, as indicated by the reported cost of dwellings, which range from $\$ 533$ to $\$ 2,096$.

Oregon is famous for its high class live stock, which is an important factor in farm revenues. Statistics show that the value of live stock upon Oregon farms ranges from $\$ 271$ to $\$ 13,423$.

The progressiveness of the Oregon farmer is shown in his farm equipment. It is shown by data of the agricultural survey that the value of implements and machinery maintained upon the farms of this state range from $\$ 100$ to $\$ 1,641$. Statistics also show that the annual gross receipts of individual farms are good, ranging from $\$ 786$ to $\$ 7,800$. The average income per family upon the farm is a good index as to the general prosperity of the farmer. This income ranges from $\$ 358$ to $\$ 4,307$. While the average income is good the standard of living is also good, but not in any way extravagant. The tables show that the average family expenses range from $\$ 267$ to $\$ 841$. These amounts should afford good wholesome living and at the same time it does not indicate that it is unreasonably expensive to live on a farm.

Farming is not a get-rich-quick occupation, but under intelligent systems of husbandry a good wholesome prosperity is assured. Under good systems of farm management the risk from loss upon capital invested is small, thus the percentage of profit on invested capital is not so great as in some other fields of industry. However, the data collected indicate that the percentage of profit, including the family labor, upon the capital invested ranges from 4.37 per cent to 14.28 per cent. 


\title{
THE LIVE STOCK INDUSTRY IN OREGON.
}

\author{
By E. L. PotTer
}

Professor of Animal Husbandry.

STATISTICS ON CATTLE.

\begin{tabular}{|c|c|c|c|}
\hline DIVISION. & $\begin{array}{l}\text { Per cent. } \\
\text { Increase. }\end{array}$ & $\begin{array}{l}\text { Acres per } \\
\text { head. }\end{array}$ & $\begin{array}{l}\text { Value per } \\
\text { Acre. }\end{array}$ \\
\hline 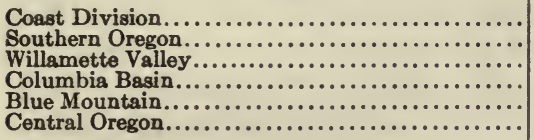 & $\begin{array}{r}100.00 \\
78.33 \\
90.00 \\
58.92 \\
68.05 \\
61.26\end{array}$ & $\begin{array}{r}4.00 \\
5.00 \\
6.93 \\
6.47 \\
5.50\end{array}$ & $\begin{array}{r}\$ 12.00 \\
41.25 \\
12.00 \\
10.96 \\
21.78 \\
2.50\end{array}$ \\
\hline 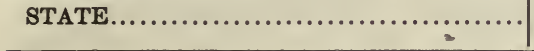 & 79.33 & 4.33 & $\$ 25.30$ \\
\hline
\end{tabular}

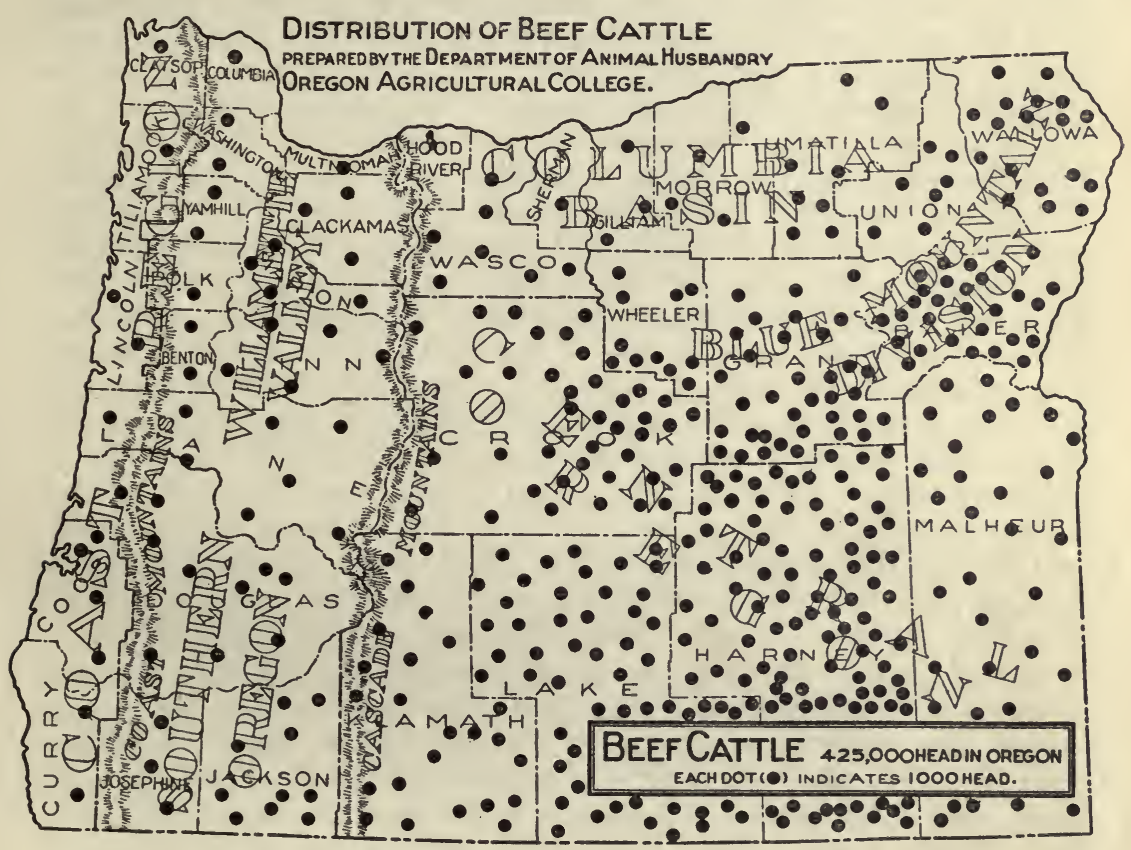

BEEF CATTLE.

(2CORDING to the 1910 census there are about 425 thousand 2 beef cattle in Oregon. There are no "exact figures available for the present year but it is well known by all stockmen that the number is much less than two years ago. It is very probable that 350 thousand would be about the correct number at the present time. It will be noted from the map that the cattle are scattered throughout the state, but are particularly numerous through the Blue Mountain 
and south central portions; in other words, they are most abundant in the range districts. In the south central portion, beef cattle is very decidedly the dominant industry. Harney county, for example, has 4000 people and 100,000 cattle or 25 cattle per capita. Wisconsin claims to be a great dairy state and has recently been featuring the fact that she has one cow for every two inhabitants.

The cattle industry in Oregon may be divided into four divisions; the range cattle industry; the raising of cattle on the grain and hay farms; the fattening of beef on alfalfa; and the raising of pure bred cattle.

Of these industries the range industry is by far the most important. The bulk of the cattle in Oregon are run on the Government ranges in much the same manner as the sheep. In the winter they are brought down on the low land to graze the grass which has been left from summer and in addition are given some hay. The range men are quite uniform in stating that it takes just about one ton of hay to winter a beef cow or steer. In summer these cattle are allowed to run out on the open ranges. In some cases they run on the lower and dryer hills which are not suitable for sheep raising. Many, however, are run on the forest reserves in the Blue Mountains. The cattle men own some land which they use for headquarters and where they raise hay and feed for winter. Many of them also own considerable areas of range land, especially for winter use. Very few own any considerable portion of the land which they use in the summer time. The size of the cattle men's holdings varies from thousands of acres of land and thousands of cattle down to the little ranch and a few cows. The great majority, however, of the smaller class own perhaps a few hundred acres of land, only a small portion of which is tillable and of any particular value, and from 100 to 400 head of cattle. The Blue Mountain district is particularly the home of the small cattle man. As with sheep it requires rather more capital to start up in the cattle business than on a small general farm, yet $\$ 10,000$ makes a good start.

The grain and hay farmers in the irrigated valleys in Eastern Oregon, particularly in the Blue Mountain section very commonly raise a few cattle as a side issue. They will have on these farms from 25 to 100 head which they will winter on the meadows, stubble fields, and straw stacks, supplemented with a little alfalfa or clover hay. In the summer time these cattle are put out on the hills, on the ranges, or on privately owned pastures. They are then given little attention through the summer; the owner in the meantime devoting his time to the raising of grain and hay. In the fall they are brought down again and wintered as has been outlined. This method of handling is not adaptable to large numbers but is quite profitable as a side issue to general farming.

The fattening of beef cattle in the winter time is confined entirely to the irrigated alfalfa districts. The practice in these localities is very uniform and the process quite simple. The steers are brought in in the fall, generally at weights from 1000 to 1100 pounds and put 
on alfalfa hay. They are given all the alfalfa they can be persuaded to eat, which will be about 40 pounds per head daily. Upon this feed they will gain from 1 to 2 pounds per day and at the end of from 3 to 5 months will show a fair degree of finish and will be sent to market. This industry makes a market for thousands of tons of good alfalfa hay, besides returning the manure to the land and providing Western markets with good beef at the time when it is most needed. A few feeders use a little grain in connection with the alfalfa, usually from 5 to 10 pounds per day. The use of grain, however, is very much the exception and most of the feeders use nothing but hay.

HOGS.

STATISTICS ON HOGS

\begin{tabular}{|c|c|c|c|}
\hline DIVISION. & $\begin{array}{l}\text { Average per } \\
\text { Litter. }\end{array}$ & $\begin{array}{l}\text { Per cent. of } \\
\text { Two Litters. }\end{array}$ & $\begin{array}{l}\text { Per cent. of } \\
\text { One Litter. }\end{array}$ \\
\hline \multirow[t]{2}{*}{ 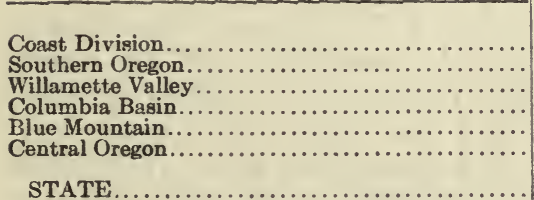 } & $\begin{array}{l}\text { No. } \\
9.25 \\
8.22 \\
7.44 \\
6.63 \\
7.52 \\
8.61\end{array}$ & $\begin{array}{c}\text { Per Cent. } \\
75.00 \\
69.43 \\
80.55 \\
58.74 \\
87.09 \\
80.00\end{array}$ & $\begin{array}{c}\text { Per Cent. } \\
25.00 \\
30.57 \\
19.45 \\
41.26 \\
12.81 \\
20.00\end{array}$ \\
\hline & 7.80 & 69.84 & 30.16 \\
\hline
\end{tabular}

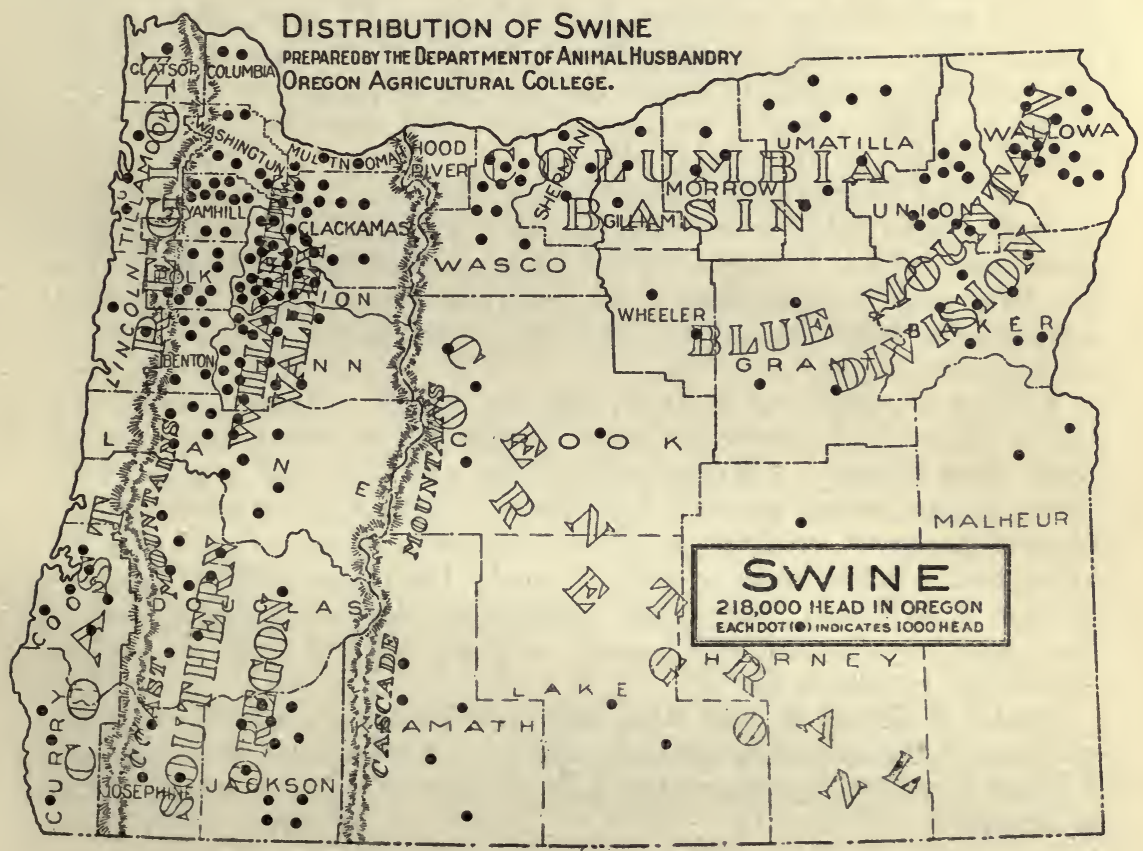


According to the census of 1910 there were 218,000 hogs in Oregon, distributed mainly through the grain and general farming sections as will be shown in the map. At the present time we have no accurate figures but the number in the state must be about 500,000. During the year of 1910, Oregon sent to the Portland Stock Yards, 26,000 head. In 1912, Oregon shipped 65,000 to Portland; considerably more than twice as many. It is interesting to note that five years ago three-fourths of the hogs used in Portland were shipped from Nebraska. Two years ago about two-fifths were from that state while in 1912 practically none were from Nebraska or any of the corn states. At the present time Oregon supplies about onehalf of the hogs used in Portland while the other half comes from Idaho, Washington, and Utah with a very few from the other neighboring states. There are still, however, large quantities of cured pork products shipped into Oregon and the Northwest from the corn states.

The average number of pigs per litter according to the investigations of this bureau is 7.51 in Eastern Oregon and 8.34 in Western Oregon. 76 per cent of the farmers raise two litters per year.

There are very few exclusive hog farms in Oregon at the present time. Nearly all of the hogs are raised in connection with the grain, stock, and dairy farms. The dairy farmers are feeding a large portion of their skim milk to hogs and find that it pays them well. The Oregon Experiment Station has found, as result of eleven different experiments, that where skim milk is fed with grain to hogs during the fattening period there is required 301 pounds of ground grain (wheat or barley) and 331 pounds of skim milk to make 100 pounds of pork. Where the grain was fed alone 456 pounds of grain was required to make 100 pounds of pork. As an average of these experiments it was found that 213 pounds of skim milk took the place of 100 pounds of grain.

In the Columbia Basin the wheat raisers find that they can raise a few hogs to clean up the thrashing yards and stubble fields and make several hundred pounds of pork at practically no cost. On the irrigated farms especially in the Blue Mountain district, large numbers of hogs are raised on alfalfa pasture with a little grain in addition.

Taking the state as a whole, the abundance of forage crops, the cooler climate, and freedom from disease make it possible to raise pork very cheaply. Wheat and barley are the chief grains used. These grains, when ground, have proven fully equal if not superior to corn for pork production. The corn belt farmers figure that it takes about 500 pounds of corn to make 100 pounds of pork. The Oregon Experiment Station has conclusively shown by about twentyfive experiments that 100 pounds of pork can be made from 450 pounds of wheat or barley.

On some farms in the state hogs are raised on alfalfa with no grain until the fattening period. Such a practice is not very successful and is not to be recommended although it does show the value of forage. 
It is commonly claimed that hogs in Oregon do not have the diseases which occasionally devastate the herd of the eastern states. While it cannot be truthfully claimed that none of these diseases are known in Oregon, it is undoubtedly true that in our cooler climate these diseases are less virulent and do not spread so rapidly. There are whole sections of Oregon where practically no disease has ever been present.

In the breeding of pure bred hogs Oregon has made rapid strides. The Willamette Valley has more good pure bred hogs than any other section of the West, but even then can hardly supply the demand.

\section{HORSES.}

\section{STATISTICS ON HORSES.}

\begin{tabular}{|c|c|c|c|c|c|c|c|c|c|c|c|}
\hline \multirow{2}{*}{ DIVISION. } & \multirow{2}{*}{$\begin{array}{l}\text { Total } \\
\text { Reports. }\end{array}$} & \multicolumn{9}{|c|}{$\begin{array}{l}\text { Number reporting the price necessary to make } \\
\text { a profit on a 4-year-old horse. }\end{array}$} & \multirow{2}{*}{$\begin{array}{l}\text { Rate of } \\
\text { Increase. }\end{array}$} \\
\hline & & $\begin{array}{c}\$ 40 \\
\text { to } \\
559\end{array}$ & $\mid \begin{array}{c}60 \\
\text { to } \\
579\end{array}$ & $\mid \begin{array}{c}80 \\
\text { to } \\
\$ 99\end{array}$ & $\begin{array}{c}\$ 100 \\
\text { to } \\
\$ 124\end{array}$ & $\begin{array}{l}\$ 125 \\
\text { to } \\
\$ 149\end{array}$ & $\mid \begin{array}{c}\$ 150 \\
\text { to } \\
\$ 174\end{array}$ & $\mid \begin{array}{c}\$ 175 \\
\text { to } \\
\$ 199\end{array}$ & $\begin{array}{c}\$ 200 \\
\text { to } \\
\$ 224\end{array}$ & $\begin{array}{l}\text { Above } \\
\$ 225\end{array}$ & \\
\hline $\begin{array}{l}\text { Coast Division.......... } \\
\text { Southern Oregon....... } \\
\text { Willamette Valley...... } \\
\text { Columbia Basin ........ } \\
\text { Blue Mountain ......... } \\
\text { Central Oregon........ }\end{array}$ & $\begin{array}{r}86 \\
8 \\
255 \\
145 \\
99 \\
142\end{array}$ & $\begin{array}{l}1 \\
\cdots \\
2 \\
5 \\
4\end{array}$ & $\begin{array}{r}\cdots \\
\cdots \\
6 \\
6 \\
16\end{array}$ & $\mid \begin{array}{r}\cdots \\
\cdots \\
\cdots \\
5 \\
6\end{array}$ & $\begin{array}{r}2 \\
13 \\
46 \\
27 \\
35\end{array}$ & $\begin{array}{r}3 \\
1 \\
13 \\
22 \\
15 \\
20\end{array}$ & $\begin{array}{r}15 \\
5 \\
104 \\
48 \\
29 \\
43\end{array}$ & $\begin{array}{r}12 \\
1 \\
32 \\
6 \\
3 \\
3\end{array}$ & $\begin{array}{r}22 \\
1 \\
60 \\
15 \\
9 \\
10\end{array}$ & $\begin{array}{c}31 \\
\cdots \\
27 \\
\cdots \cdots \cdots \\
\cdots\end{array}$ & $\begin{array}{l}76.25 \\
88.75 \\
81.50 \\
60.12 \\
70.05\end{array}$ \\
\hline STATE............. & 735 & 12 & 32 & 13 & 123 & 74 & 244 & 57 & 117 & 63 & 76.34 \\
\hline
\end{tabular}

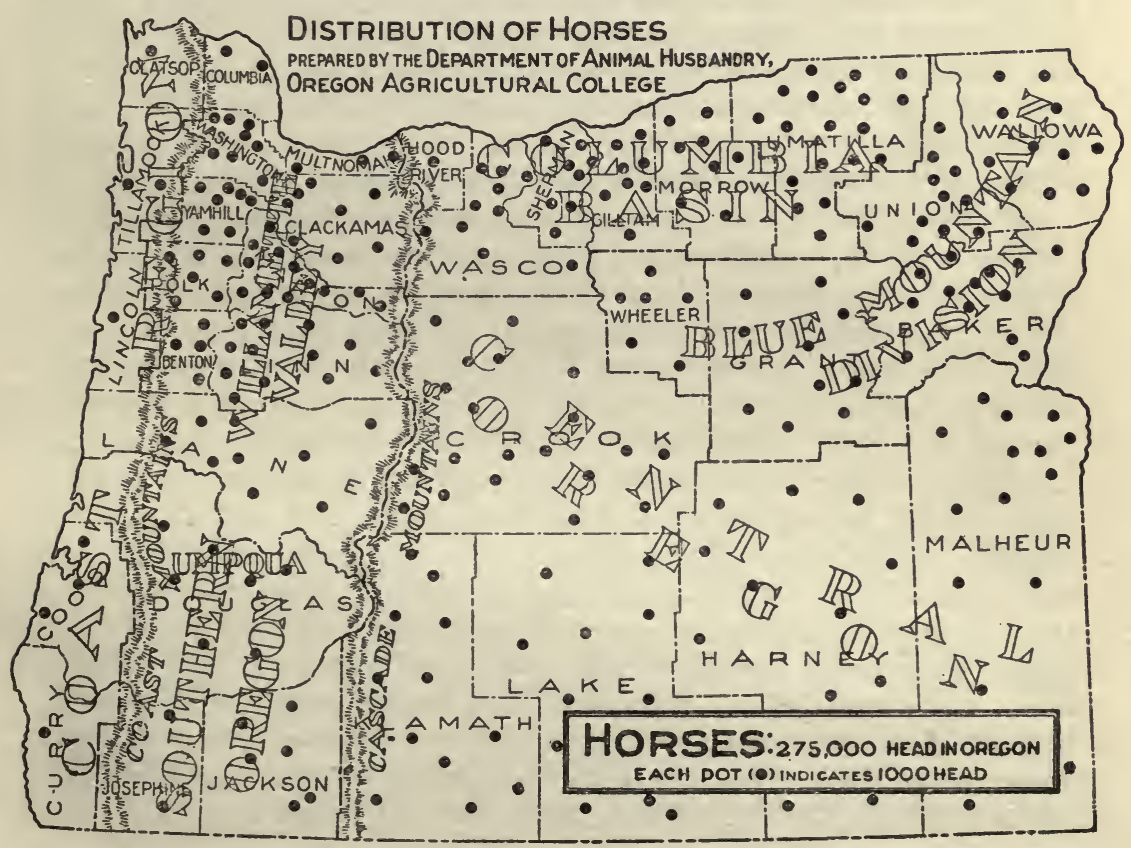


There are in the state of Oregon some 275,000 horses, with a total value of about 37 million dollars. These horses, as is shown by the accompanying map, are scattered pretty well throughout the state. They are rather more numerous in the more thoroughly tillable portions, such as in the Willamette Valley and Columbia basin, yet we find them everywhere; on the grain and hay farms, the fruit farms, the wheat farms, the alfalfa farms, and on the ranges. The larger portion of the horses in Oregon are raised by the farmer who has a few mares to do his farm work and who sells a few colts each year as a by-product. Nearly all of the farmers in the grain and hay districts raise a few colts, but there are not very many who are in the horse business on a large scale. The raising of colts on these small farms has always been a fruitful source of income. In Western Oregon, a large portion of the farmers interviewed reported that they could sell a four-year-old colt for $\$ 150$ or less and make a good profit. A considerable number stated that they could do well at selling colts at from $\$ 100$ to $\$ 125$. In actual practice it has been a good many years since a good four-year-old colt in Oregon was not worth more than $\$ 150$. By a little care in the selection of a good stallion it is possible to raise colts from common mares which will sell from $\$ 200$ to $\$ 250$ each. Most of our farmers, who have been breeding their common mares to good pure bred stallions for several years, are selling their colts for these prices. The wheat farms of the Columbia basin are among the most favorably situated for horse production. Nearly all of these farms have some waste land which in connection with the straw and stubble fields are especially useful in raising a few horses; second, the big, strong draft horses which the market demands are just the kind of horses which these farmers need to pull their heavy machinery; and third, the man who raises a good many horses can afford to keep enough to do his farm work at the right season and for that reason raises larger crops.

In Central Oregon we have horses raised on the farms in the manner outlined but in addition have large numbers raised on the ranges. It will be noted from the table that a good many farmers of Eastern Oregon reported the price necessary for a four-year-old horse at about $\$ 75$. The men giving this price were practically all range stockmen. These horses are allowed to run out on the open range for the greater part of the year. Some do not feed at all during the winter, but most feed a little hay. At the other extreme we find men who have their ranges fenced and who feed both grain and hay during the winter. Under the latter system the cost is greater than $\$ 75$ per head but the price actually received is much greater, in many cases twice as much. There are not a great number of stockmen raising horses exclusively but all of the cattle and sheep men raise a good many after the manner indicated. In former years, little attempt was made at better blood and such improved stock as was introduced was of the light breeds as the standard bred and thoroughbred. More recently, however, much draft blood is being introduced and 
the popular stallion at present is a grade drafter of the Percheron, Shire, or Clydesdale breed. The most progressive, however, are using pure breds and the others are beginning to see their advantages.

There are several nice studs of pure bred horses, especially in Western Oregon and the Blue Mountain region. Some of the finest pure breds to be found in the country are raised here. They are not, however, raised in sufficient numbers to meet the home demand for breeding stock and many stallions and mares are brought in each year from the eastern states and from Europe.

The report of the State Stallion Registration Board shows that $58 \%$ of the stallions of the state are pure bred whereas the average of the entire United States is less than $50 \%$ pure bred. $45 \%$ of the stallions in Oregon are pure bred draft horses, so it can be seen that the Oregon farmer is improving his horses along the most approved lines.

Mules have not proven popular with the farmers in the Western part of the state and few are used or raised. In the wheat fields of the Columbia basin they are quite popular and a large percentage of the mules in the state are found in this section. The wheat raisers find them very useful on their heavy machinery and they both buy and raise a good many. In Central Oregon, not many are worked, but there are a good many raised on the ranges. The mules seem particularly adapted to range conditions and it has been found possible to raise splendid mules on the ranges even from common mares. Central Oregon and the Blue Mountain section are about the only parts of the state which produce a surplus of mules. These are mostly shipped to California and the other states to the South. Most of the jacks come from the southern corn-belt states although there are a few herds of jennets in Oregon and some very good jacks are being raised. They meet with a good demand in the mule raising sections of the state.

\section{SHEEP.}

\section{STATISTICS ON SHEEP.}

\begin{tabular}{|c|c|c|c|c|c|c|c|}
\hline DIVISION & $\begin{array}{l}\text { Per Cent. } \\
\text { Increase. }\end{array}$ & $\begin{array}{l}\text { Loss From } \\
\text { Wild } \\
\text { Animals. }\end{array}$ & $\begin{array}{l}\text { Average. } \\
\text { Wool Clip }\end{array}$ & $\begin{array}{c}\text { Cost of } \\
\text { Winter- } \\
\text { ing. }\end{array}$ & $\begin{array}{l}\text { Pasture } \\
\text { per Head }\end{array}$ & $\begin{array}{c}\text { Value } \\
\text { Land per } \\
\text { Acre. }\end{array}$ & $\begin{array}{l}\text { Age Ewes } \\
\text { are sold. }\end{array}$ \\
\hline $\begin{array}{l}\text { Southern Division...... } \\
\text { Coast Division ......... } \\
\text { Willamette Valley....... } \\
\text { Columbia Basin....... } \\
\text { Blue Mountain .......... } \\
\text { Central Oregon........ }\end{array}$ & \begin{tabular}{|r|} 
Per Cent. \\
85.9 \\
102.5 \\
87.38 \\
88.25 \\
82.71 \\
83.75
\end{tabular} & $\begin{array}{r}\text { Per Cent. } \\
3.00 \\
1.20 \\
6.50 \\
3.25 \\
6.91 \\
\mathbf{5 . 6 2}\end{array}$ & $\begin{array}{r}\text { lb. } \\
8.66 \\
8.12 \\
10.50 \\
7.34 \\
8.35 \\
9.50\end{array}$ & $\begin{array}{l}.50 \\
.41 \\
.50 \\
.83 \\
.71 \\
.63\end{array}$ & $\begin{array}{l}\text { A. } \\
2.27 \\
2.42 \\
1.20 \\
1.40 \\
2.95 \\
2.50\end{array}$ & $\begin{array}{c}\$ 16.93 \\
28.54 \\
38.3 \\
8.40 \\
15.38 \\
6.00\end{array}$ & $\begin{array}{l}\text { Yrs. } \\
5.36 \\
7.12 \\
\mathbf{5} .38 \\
\mathbf{5 . 5 3} \\
7.11 \\
\mathbf{6 . 7 5}\end{array}$ \\
\hline STATE. & 88.36 & 5.25 & 9.11 & .65 & 2.23 & 22.16 & 6.1 \\
\hline
\end{tabular}




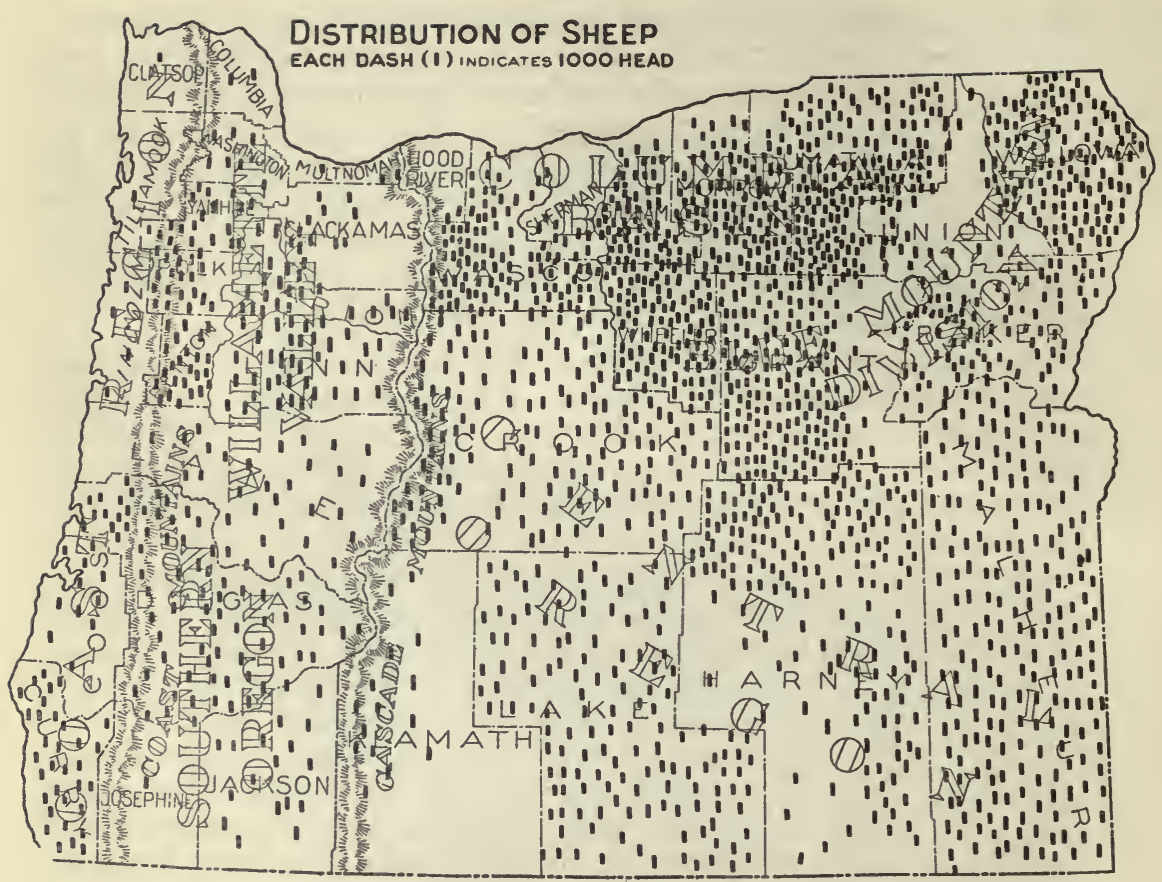

There are at the present time over 3 million sheep in the state of Oregon. Sheep are grown in all parts of the state, especially in Eastern Oregon, but as will be shown on the map, the sheep centers are along the border between the Columbia Basin and the Blue Mountain section. In Western Oregon most of the sheep are raised in the Willamette Valley.

Sheep raising in Oregon may be divided into three divisions; raising sheep on the range for mutton and wool; raising of spring lambs in the Willamette valley and other parts of Western Oregon; and the raising of pure bred sheep.

The range sheep industry is a very large one in this state. The report of the Tariff Board based upon accurate figures concerning 230 thousand sheep in this state gives the following interesting information: The average wool clip per head is 8.9 pounds, this wool being produced at a cost of somewhat less than 11 cents per pound after allowing for all expenses, salary of manager, cost of feed and pasture. The average per centage of increase was 79.6 per cent. The Oregon Statistical Bureau, however, shows for the farmers interviewed an average per centage increase of 84.3 per cent for Eastern Oregon, and an average wool clip of 9.38 pounds. It will thus be seen that the average wool clip and the average per centage of increase of both are considerably above the average of the whole United States, or even of the entire West. According to the Tariff Board report the average wool clip of the entire West is 7.3 pounds and an average increase of 70.3 per cent. 
Most of the range sheep are run on the lower lands in the winter time where they are grazed on the dry bunch grass left over from summer. Where there is an abundance of this grass, it cures down and makes a good nutritious feed. Such grass is, however, always supplemented with more or less hay during the winter. The Eastern Oregon sheep men report an annual average expenditure of 72 cents per head for hay and forage for wintering. During the summer these sheep are driven on the higher mountains where they can get green grass throughout the year. The lower sage brush hills become quite dry in July and August and are not suitable for pasture for ewes and lambs, although they may be splendid during other seasons of the year. In the higher mountains, however, there is much green grass, particularly in the forest reserves, and it is here that most of the sheep are kept during midsummer. There are immense bands of sheep throughout the Blue Mountains and on the eastern slope of the Cascades. The sheep are usually handled in bands from 2000 to 2500 . It has been found that they can be handled more economically and profitably in bands of this size. Very few men attempt to run sheep on the range with very many less than this. Where they have a larger number, they are subdivided into several bands of about this size. In Eastern Oregon, about 1600 sheep are run for each twelve months employee.

There are many large sheep men whose holdings run up to several thousands. The great majority, however, do not own nearly so many. There are hundreds of men throughout the state running just one band of ewes and doing very nicely with them. It takes little more money to start a band of sheep than to start a small farm, but at the same time it does not require any excessive amount of capital. In the early days there were many bands of sheep owned by men who had no real estate holdings whatever. This condition, however, no longer exists and all of the sheep men now have some land where they raise hay and provide winter quarters for their sheep. They may also own a good deal of their range, particularly their winter range. Their summer range is nearly always on Government land and commonly in the forest reserves.

The raising of spring lambs in Western Oregon is a radically different industry from the range sheep business east of the Cascade Mountains. A very large portion of the small farmers in Western Oregon handle a few sheep, generally from 10 to 50 head. These are allowed to rough it through the winter, picking up a little grass around the fences and being fed a little hay in the winter. The lambs come rather early and grow rapidly on pasture or forage crops, such as rye, vetch, clover, and rape. The springs are much earlier than in Eastern Oregon and there is a greater abundance of green forage so that the lambs are both born earlier and grow faster. They are usually ready for market before July. Many of them are put on the market at a much earlier time than this and it is entirely feasible and practicable to market these lambs in March or April, as some of the most progressive farmers are already doing. After the lambs are 
gone, the ewes are allowed to rough it and pick up their living around the stubble fields and meadows. Handled in this way a few sheep on the farm clean up a lot of weeds and waste material and so cost very little, but at the same time bring in quite an income. These sheep are practically all of the mutton breeds, mostly Cotswold and Shropshire. There are very few Merinos.

The raising of pure bred sheep has become quite an industry in Oregon and has made some parts of the state famous throughout the country. In Eastern Oregon there are a number of large flocks of very high grade sheep, particularly of the Merino and Rambouillet strains. One company has in Eastern Oregon probably spread more good Merino and Rambouillet stock through the Northwest than any other firm. Western Oregon and particularly the Willamette valley has become famous as a breeding ground for high class long wool sheep, particularly of Cotswold and Lincoln breeds. It seems that the climatic and forage conditions in this section are peculiarly adapted to these breeds and we find them developed to a degree of perfection which is not equaled anywhere else in the United States. Recently prominent importers of Cotswold and Lincoln sheep, who have been in the habit of sending to England every year for sheep for Eastern shows have come to the Willamette valley and have been able to get better stuff than they could import. Many of the best flocks of long wool sheep in the Willamette valley have been bred in this district for many years.

On the whole the raising of sheep in Oregon is one of the most extensive of the live stock industries. There is no other line of agriculture in the state which has already built up as many substantial fortunes and there is no other which offers a better promise of the future.

\section{GOAT RAISING IN OREGON.}

Goat raising has become a prominent industry in the western part of the state. Oregon ranks among the leading goat raising states of the Union, being about third as to numbers and distinctly first as to quality. The finest Angoras in America are produced in the Willamette valley and they are produced in large numbers. Throughout the foothill section of Western Oregon, especially in the coast district, we find considerable areas of brushy, rough, land. This condition combined with our mild winters and cool summers makes an ideal place for goats. The goats shear nearly as heavy a fleece as do sheep and the mohair has been selling at from 35 to 45 cents per pound. In addition to the income from the mohair there is a still greater income from clearing up the brush. Many of these brushy pastures which are practically worthless in the beginning are made into valuable land by pasturing with goats for a few years. There are still immense areas of Western Oregon which are at the present time producing little or nothing, but which would produce a good income with goats and after a few years of pasturing would be valuable for many other purposes. 


\title{
THE DAIRY INDUSTRY IN OREGON.
}

\author{
By F. L. Kant
}

Professor of Dairy Husbandry.

(2) stated elsewhere in this publication, it was deemed advisable 2 to consider the results of the survey by districts rather than to regard each county as a separate unit. The general scheme of making six divisions of the state has been followed in considering the data gathered relative to dairying. However, it was thought advisable to set forth certain facts relative to each county in the several divisions and accordingly the table on this page has been prcpared from the latest U.S. census figures. The special dairy item in this table states the number of dairy cows in each county, and incidentally shows the relation of dairy cows to population and acreage. It will be observed

\section{POPULATION, AREA, NUMBER DAIRY COWS. \\ Report U. S. Census for 1910.}

\begin{tabular}{|c|c|c|c|c|c|}
\hline & Population. & Area, Acres. & $\begin{array}{l}\text { Per Cent. } \\
\text { Land in } \\
\text { Farms. }\end{array}$ & No. Farms. & $\begin{array}{l}\text { No. } \\
\text { Dairy Cows. }\end{array}$ \\
\hline $\begin{array}{l}\text { Coast Division: } \\
\text { Clatsop............. } \\
\text { Coos................. } \\
\text { Curry } \ldots . . . . . . . . . \\
\text { Lincoln............ } \\
\text { Tillamook.......... }\end{array}$ & $\begin{array}{r}16,106 \\
17,959 \\
2,044 \\
5,587 \\
6,266\end{array}$ & $\begin{array}{r}525,440 \\
1,041,920 \\
958,720 \\
645,120 \\
720,000\end{array}$ & $\begin{array}{l}10.3 \\
19.4 \\
11.1 \\
24.5 \\
13.1\end{array}$ & $\begin{array}{r}369 \\
1,128 \\
292 \\
961 \\
651\end{array}$ & $\begin{array}{l}3,325 \\
8,544 \\
1,948 \\
3,385 \\
8,481\end{array}$ \\
\hline 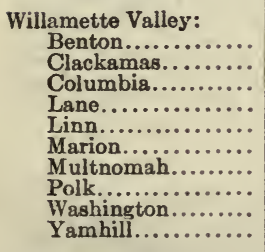 & $\begin{array}{r}10,663 \\
29,931 \\
10,580 \\
33,783 \\
22,662 \\
39,780 \\
226,261 \\
13,469 \\
21,522 \\
18,285\end{array}$ & $\begin{array}{r}440,320 \\
1,192,960 \\
423,680 \\
2,951,680 \\
1,435,520 \\
764,160 \\
288,640 \\
453,760 \\
467,840 \\
456,960\end{array}$ & $\begin{array}{l}53.5 \\
25.2 \\
21.6 \\
16.4 \\
32.2 \\
51.6 \\
29.9 \\
57.4 \\
51.4 \\
60.0\end{array}$ & $\begin{array}{l}1,098 \\
3,646 \\
813 \\
2,826 \\
2,751 \\
3,490 \\
1,478 \\
1,557 \\
2,871 \\
2,218\end{array}$ & $\begin{array}{r}5,083 \\
11,378 \\
4,515 \\
10,891 \\
13,802 \\
13,467 \\
7,777 \\
5,931 \\
12,678 \\
7,751\end{array}$ \\
\hline $\begin{array}{l}\text { Southern Oregon: } \\
\text { Douglas............. } \\
\text { Jackson } \ldots . . . \cdots \cdots \cdots \\
\text { Josephine.......... }\end{array}$ & $\begin{array}{r}19,674 \\
25,756 \\
9,567\end{array}$ & $\begin{array}{r}3,150,080 \\
\quad 1,815,040 \\
\quad 1,120,640\end{array}$ & $\begin{array}{l}18.3 \\
16.4 \\
10.9\end{array}$ & $\begin{array}{r}2,124 \\
1,714 \\
855\end{array}$ & $\begin{array}{l}6,666 \\
3,824 \\
2,011\end{array}$ \\
\hline $\begin{array}{l}\text { Columbia Basin: } \\
\text { Gilliam ............. } \\
\text { Hood River....... } \\
\text { Morrow............ } \\
\text { Sherman......... } \\
\text { Umatilla } \ldots \ldots \ldots \ldots \ldots \\
\text { Wasco............. }\end{array}$ & $\begin{array}{r}3,701 \\
8,016 \\
4,357 \\
4,242 \\
20,309 \\
16,336\end{array}$ & $\begin{array}{r}768,640 \\
347,520 \\
1,296,000 \\
535,040 \\
2,030,720 \\
1,499,520\end{array}$ & $\begin{array}{l}56.5 \\
10.9 \\
52.0 \\
69.6 \\
51.7 \\
36.3\end{array}$ & $\begin{array}{r}432 \\
744 \\
614 \\
486 \\
2,005 \\
1,331\end{array}$ & $\begin{array}{r}896 \\
780 \\
1,653 \\
953 \\
4,651 \\
2,386\end{array}$ \\
\hline 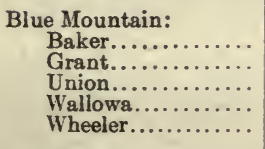 & $\begin{array}{r}18,076 \\
5,607 \\
16,191 \\
8,364 \\
2,484\end{array}$ & $\begin{array}{l}1,958,400 \\
2,892,800 \\
1,335,680 \\
2,012,800 \\
1,090,560\end{array}$ & $\begin{array}{l}15.2 \\
15.4 \\
29.6 \\
17.6 \\
38.1\end{array}$ & $\begin{array}{r}1,304 \\
773 \\
1,309 \\
1,058 \\
387\end{array}$ & $\begin{array}{l}4.802 \\
3,053 \\
4,681 \\
3.420 \\
1,277\end{array}$ \\
\hline 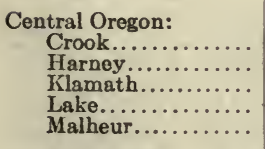 & $\begin{array}{l}9,315 \\
4,059 \\
8,554 \\
4,658 \\
8,601\end{array}$ & $\begin{array}{l}4,977,920 \\
6,357,120 \\
3,839,360 \\
5,068,800 \\
6,325,120\end{array}$ & $\begin{array}{r}11.5 \\
8.8 \\
11.8 \\
7.9 \\
3.6\end{array}$ & $\begin{array}{r}1,355 \\
443 \\
926 \\
712 \\
801\end{array}$ & $\begin{array}{l}2,908 \\
1,840 \\
3,166 \\
1,733 \\
2,888\end{array}$ \\
\hline THE STATE......... & 672,765 & $61,188,480$ & 19.1 & 45,502 & 172,550 \\
\hline
\end{tabular}


that, in the state as a whole, the table shows practically one cow for each four persons, and one cow for each 354 acres of the whole area, or one cow for each 67.6 acres of the reported area in farms. In one county only, Tillamook, is the number of cows greater than the population.

The ratio of dairy cows to population as shown in the foregoing table, practically one to four, is even higher at the present time because the human population has increased more rapidly than the "cow" population. Comparing the cows and population in some of the best known dairy states we find the following:

\begin{tabular}{|c|c|c|c|}
\hline STATE. & Population. & No. Cows. & $\begin{array}{l}\text { Population } \\
\text { Per Cow. }\end{array}$ \\
\hline $\begin{array}{l}\text { Wisconsin } \ldots \ldots \ldots \\
\text { Minnesota } \\
\text { Iowa }\end{array}$ & $\begin{array}{l}2,333,860 \\
2,075,708 \\
2,224,771\end{array}$ & $\begin{array}{l}1,473,505 \\
1,085,388 \\
1,406,792\end{array}$ & $\begin{array}{l}1.6 \\
2.0 \\
1.6\end{array}$ \\
\hline
\end{tabular}

It will be observed that the number of cows in proportion to population is about two and one-third times greater in the three states referred to than in the state of Oregon. This condition of affairs would seem to indicate that there need be no fear of dairy over-production in Oregon in the very near future. Further, the census figures show that the state of Washington on the North has $1,141,900$ people and 186,233 cows, or one cow to about every six people, and California, our Southern neighbor, has 2,377,549 people and 467,332 dairy cows, or practically one cow for every five people. With Oregon alone importing annually nearly 100 carloads of dairy products it does not appear that there can be any question as to the demand for the local product on the Pacific coast.

\section{NUMBER AND VALUE OF COWS AND HEIFERS.}

\begin{tabular}{|c|c|c|c|c|c|c|}
\hline & $\begin{array}{c}\text { Coast } \\
\text { Division. }\end{array}$ & $\begin{array}{l}\text { Willam- } \\
\text { ette } \\
\text { Valley. }\end{array}$ & $\begin{array}{l}\text { Southern } \\
\text { Oregon. }\end{array}$ & $\begin{array}{c}\text { Columbia } \\
\text { Basin. }\end{array}$ & $\begin{array}{l}\text { Blue } \\
\text { Mts. }\end{array}$ & Central \\
\hline 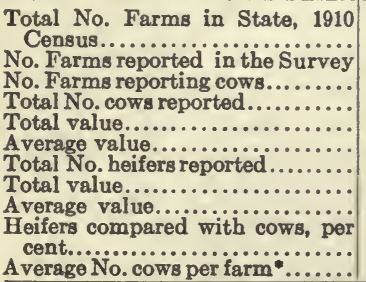 & \begin{tabular}{|r|}
4214 \\
176 \\
158 \\
3681 \\
$\$ 205,003.00$ \\
$\$ 55.70$ \\
1052 \\
$\$ 37,299.00$ \\
$\$ 35.45$ \\
\\
28.6 \\
22.7
\end{tabular} & $\begin{array}{r}21935 \\
556 \\
455 \\
3330 \\
\$ 228,416.00 \\
\$ 68.60 \\
1429 \\
\$ 53,166.00 \\
\$ 37.20 \\
43.5 \\
7.3\end{array}$ & $\begin{array}{r}4693 \\
231 \\
165 \\
883 \\
\$ 49,761.00 \\
\$ 56.35 \\
231 \\
\$ 7,992.00 \\
\$ 34.60 \\
\$ \quad 26.2 \\
5 \\
5.4\end{array}$ & \begin{tabular}{|r|}
5592 \\
235 \\
79 \\
448 \\
$\$ 28,176.00$ \\
$\$ 52.90$ \\
202 \\
$\$ 5,714.00$ \\
$\$ 28.29$ \\
45.1 \\
5.7
\end{tabular} & $\begin{array}{r}4831 \\
201 \\
76 \\
721 \\
\$ 41,227.00 \\
\$ 57.18 \\
164 \\
\$ 5,807.00 \\
\$ 35.41\end{array}$ & $\begin{array}{r}4237 \\
212 \\
140 \\
1004 \\
\$ 65,198.00 \\
\$ 64.94 \\
348 \\
\$ 14,428.00 \\
\$ 38.60\end{array}$ \\
\hline
\end{tabular}

Average number of cows per farm applies to number of farms reporting cows, not to whole number of farms reported.

Values as given for both cows and heifers are somewhat lower than actual prices at which sales are being made at this time (April, 1913). Good grade cows in the Willamette Valley are selling at $\$ 70.00$ to $\$ 75.00$ and choice grades $\$ 80.00$ to $\$ 90.00$. Pure bred animals are of course higher, the prices depending considerably on quality. 
In the Columbia Basin, Blue Mountain and Central Divisions, dairy cattle values are now considerably higher than shown in the table. Quite a number of young animals have been brought into these sections within twelve months, from Wisconsin, Illinois, Iowa, and probably other middle west states. The greater portion of this stock has been of the Holstein breed, and high grade twoyear-old heifers due to freshen in the spring have cost from $\$ 75.00$ to $\$ 90.00$ "laid down" in these sections. One shipment to one town in Umatilla County consisted of 145 head, nearly all high grade Holsteins, including five registered Holstein bulls.

\section{SIZE OF HERDS AND AVERAGE VALUE PER COW.}

\begin{tabular}{|c|c|c|c|c|c|c|}
\hline & $\begin{array}{c}\text { Coast } \\
\text { Division. }\end{array}$ & $\begin{array}{l}\text { Willam- } \\
\text { ette } \\
\text { Valley. }\end{array}$ & $\begin{array}{l}\text { Southern } \\
\text { Oregon. }\end{array}$ & $\begin{array}{c}\text { Columbia } \\
\text { Basin. }\end{array}$ & $\begin{array}{l}\text { Blue } \\
\text { Mts. }\end{array}$ & Central. \\
\hline 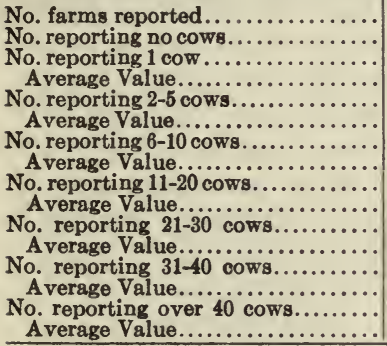 & $\begin{array}{r}14 \\
\$ 52.00 \\
25 \\
\$ 54.00 \\
47 \\
\$ 54.00 \\
29 \\
\$ 57.00 \\
25 \\
\$ 53.00 \\
18 \\
\$ 61.00\end{array}$ & $\begin{array}{r}556 \\
101 \\
39 \\
\$ 63.00 \\
234 \\
\$ 63.00 \\
102 \\
\$ 67.00 \\
53 \\
\$ 84.00 \\
15 \\
\$ 61.00 \\
5 \\
\$ 65.00 \\
\$ 84.00\end{array}$ & $\begin{array}{r}231 \\
66 \\
33 \\
\$ 57.00 \\
82 \\
\$ 58.00 \\
35 \\
\$ 55.00 \\
12 \\
\$ 53.00 \\
1 \\
\$ 50.00 \\
1 \\
\$ 70.00 \\
\$ 75.00\end{array}$ & $\begin{array}{r}235 \\
156 \\
7 \\
\$ 57.50 \\
43 \\
\$ 61.00 \\
20 \\
\$ 61.00 \\
7 \\
\$ 62.00 \\
1 \\
\$ 60.00 \\
1 \\
\$ 90.00 \\
0 .\end{array}$ & $\begin{array}{r}201 \\
125 \\
3 \\
\$ 50.00 \\
31 \\
\$ 56.00 \\
27 \\
\$ 53.00 \\
11 \\
\$ 56.00 \\
0\end{array}$ & $\begin{array}{r}212 \\
72 \\
19 \\
\$ 56.50 \\
58 \\
\$ 61.00 \\
39 \\
\$ 60.00 \\
18 \\
\$ 69.00 \\
1 \\
\$ 40.00 \\
3 \\
\$ 63.00 \\
\$ 75.00\end{array}$ \\
\hline
\end{tabular}

The purpose of the above table is to give some idea of the size of the herds kept in the various sections. It will be observed that in the Coast division, the largest number of farms keep from 11 to 20 cows, while in all other sections, on the majority of the farms five or less is the number usually found.

It will be observed that the 11-20 group is a high valuation one in the Willamette Valley. This is probably due to a consider able number of pure bred herds falling in this group.

FARMS REPORTING INCOME FROM COWS.

\begin{tabular}{|c|c|c|c|c|c|c|}
\hline & $\begin{array}{l}\text { Coast } \\
\text { Div. }\end{array}$ & $\begin{array}{l}\text { Willam- } \\
\text { ette } \\
\text { Valley }\end{array}$ & Southern & $\begin{array}{c}\text { Columbia } \\
\text { Basin. }\end{array}$ & $\begin{array}{l}\text { Blue } \\
\text { Mts. }\end{array}$ & Central. \\
\hline 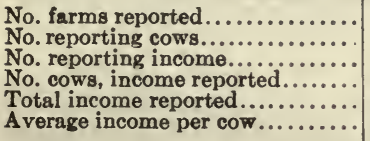 & $\begin{array}{r}176 \\
158 \\
151 \\
3609 \\
\$ 240,581.00 \\
\$ 66.66\end{array}$ & $\begin{array}{r}556 \\
445 \\
413 \\
3094 \\
\$ 219,600.00 \\
\mathbf{\$ 7 0 . 9 8}\end{array}$ & \begin{tabular}{|r|}
231 \\
165 \\
123 \\
774 \\
$\$ 44,946.00$ \\
$\$ 58.07$
\end{tabular} & \begin{tabular}{|r|}
235 \\
79 \\
34 \\
274 \\
$\$ 13,943.00$ \\
$\$ 50.88$
\end{tabular} & $\begin{array}{r}201 \\
76 \\
37 \\
353 \\
\$ 18,544.00 \\
\$ 52.53\end{array}$ & $\begin{array}{r}212 \\
140 \\
75 \\
679 \\
\$ 33,036.00 \\
\$ 48.65\end{array}$ \\
\hline
\end{tabular}

The item, "average income per cow" takes into consideration as a rule only the direct income from the sale of milk or cream as indicated by the monthly checks received. Due allowance should be made for the value of skim milk in addition, as the figures given are based on a butter fat price basis. 
While the average income as stated above probably represents average conditions pretty closely, many herds show a much higher income. An average of the three highest herds reported from each of several counties gives a figure in excess of $\$ 100.00$ per cow. For instance, in Clatsop County, three herds containing a total of 50 cows are reported as averaging $\$ 118.59$ per cow in one year. But the three herds reporting lowest income in Clatsop County, containing a total of 83 cows, show an average per cow of only $\$ 29.26$. It is probable that the figures just given include the sale of some sweet cream which can usually be sold at a price considerably in advance of ordinary prices paid for cream for butter making purposes.

In Tillamook County, where practically all milk sold is made into cheese an average of the three highest income producing herds reported, containing a total of 61 cows, shows an average per cow of $\$ 114.59$. But the three lowest producing herds, containing 71 cows, show an average per cow per year of only $\$ 37.61$. These averages are segregated from a total of 41 farms reporting incomes.

Tillamook County is the great cheese producing region of the Pacific coast, and the product has a great reputation for uniformly high quality. A co-operative selling association handles the greater portion of the product, and has proven a most effective selling agency from the standpoint of both seller and buyer. For the year 1912, the product of twenty-two factories is reported as follows:

Pounds of milk received.............. 36,534,575

Pounds of cheese made............... 4, 4, 016,150

Amount received for cheese sold........... \$646,132.90

Average price per pound............... \$ .161

Pounds cheese per 100 pounds milk........ 10.99

Information is not at hand to show how many cows produced the milk from which this four million pounds of cheese was made. But the latest U. S. census gives the total number of farms in Tillamook County as 651, and since the output of all the factories in the county is not included in the foregoing tabulation, we can safely say that the average per farm is considerably in excess of $\$ 1,000.00$.

While averages show what is actually being done by the many, the higher incomes of the few indicate what it is possible to accomplish. A bit of history of one Linn County dairy farm is of interest in this connection. About four years ago, this farm of some three hundred acres was purchased for less than $\$ 40.00$ per acre. The place had been poorly farmed and it was necessary to build a new cow barn as one of the first improvements. The family consisted of father, mother, and one grown son. They are "book farmers," that is, they keep account of the income and the expenditures of the farm and the account for the year 1912 shows a net profit of about $\$ 3,600.00$ after deducting all expenses, including an allowance of six per cent interest on the investment. The dairy herd consists of about equal numbers of pure bred and high grade Jerseys. The product is sold in the form of sweet cream, shipped nearly a hundred miles to Portland. Allowing 25 cents per hundred as the value of the skim milk, in addition to the receipts for butter fat, the average 
production per cow was $\$ 145.00$ for the year 1912 , and about $\$ 140.00$ for the year 1911, although nearly one half of the cows in 1911 were heifers with first calves. True this dairyman gets about 40 cents per pound for butter fat throughout the year, but two or three different firms were willing to pay the price for 1913, that he received in 1911 and 1912.

A less extensive report comes from Benton County, showing an income of $\$ 150.84$ for the month of March (1913), for butter fat alone sold to a creamery, from a herd of fifteen cows. Milk and cream for a family of four adults was also used on the farm. The cows in this herd for the most part freshened during September, so all were past their best milk flow. These cows are rather high grade Jerseys, but are no better than many other grade herds scattered over the state.

Cost of Milk Production: It was found to be next to impossible to secure definite data relative to the cost of producing milk and milk products. The cost of feed during the winter months as estimated by a very few dairymen ranged around $\$ 5.00$ or $\$ 6.00$ per month for cows fed a full winter ration. During the summer months in cases where pasture was available, the cost of keeping a cow was estimated at $\$ 1.00$ to $\$ 1.50$ per month. Where the soiling system was practiced the cost per cow per month was estimated at about $\$ 2.50$. If we assume that the cost of feeding the cow was $\$ 5.00$ per month for six months and $\$ 2.50$ per month for the remaining six months of the year, we bave a total feed cost of $\$ 15.00$ per cow per year. In some instances the cost would no doubt be higher than this figure and in others very much lower. But for good cows well fed for winter milk production, the feed costs would range pretty close around $\$ 45.00$ per head per year. Of course if the heaviest milk production occurs with the cows on good pasture, the feed cost will be greatly reduced.

\section{LABOR AND WAGES.}

\begin{tabular}{|c|c|c|c|c|c|c|}
\hline & $\begin{array}{l}\text { Coast } \\
\text { Div. }\end{array}$ & $\begin{array}{l}\text { Willam- } \\
\text { ette } \\
\text { Valley. }\end{array}$ & $\begin{array}{l}\text { Southern } \\
\text { Oregon. }\end{array}$ & $\begin{array}{c}\text { Columbia } \\
\text { Basin. }\end{array}$ & $\begin{array}{l}\text { Blue } \\
\text { Mts. }\end{array}$ & Central. \\
\hline 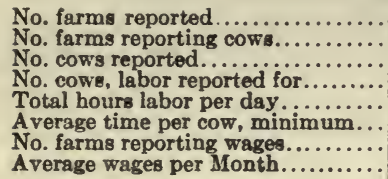 & $\begin{array}{r}176 \\
158 \\
3681 \\
3130 \\
1196 \\
23 \\
72 \\
\$ 38.30\end{array}$ & $\begin{array}{r}556 \\
455 \\
3330 \\
2698 \\
926 \\
21 \\
35 \\
\$ 38.00\end{array}$ & $\begin{array}{r}231 \\
165 \\
883 \\
761 \\
290 \\
23 \\
7 \\
734.65\end{array}$ & $\begin{array}{r}235 \\
79 \\
448 \\
286 \\
95 \\
20 \\
3 \\
\$ 35.00\end{array}$ & $\begin{array}{r}201 \\
76 \\
721 \\
260 \\
115 \\
27 \\
4 \\
438.75\end{array}$ & $\begin{array}{r}212 \\
140 \\
1004 \\
942 \\
360 \\
22 \\
6 \\
\$ 37.50\end{array}$ \\
\hline
\end{tabular}

Two systems are followed in the employment of labor on the dairy farm. The most common arrangement is to have each milker care for six to ten cows, thus putting in two or three hours per day in dairy work, and the greater part of his time in the field. As most of the dairy herds consist of less than ten cows, this plan must of necessity be the most common one. On the larger dairy farms many proprietors consider it best to have the men who do the milking spend their entire time at dairy work, and on such farms twenty 
to twenty-four cows are considered a "string", and by the time a man feeds, grooms, milks, and cleans stables for this number of cows he is considered as having done a fair day's work. In summer when the cows go to pasture, the work of feeding and cleaning stables is considerably reduced and a man will have time for some other work. On some dairy farms, it is the practice to pay hired help higher wages during the summer months and require more hours work per day than during the winter season. In some cases, as high as $\$ 50.00$ per month is paid during part of the summer, with the winter wage at $\$ 30.00$ per month. These wages as well as the averages given in the foregoing table, include board and lodging.

Quite a number of the larger dairymen, and particularly the breeders of pure bred stock, employ men with families, furnishing them with house and certain privileges in the line of garden, poultry, and dairy products. Where men are employed under this sort of arrangement, the wages range from $\$ 50.00$ to $\$ 75.00$ per month. In case the help is given a large measure of responsibility his compensation will be still higher. In still other cases a man and wife both are employed, the wife helping with the house work, and both having their board furnished by the management. Under such an arrangement, man and wife jointly receive $\$ 60.00$ to $\$ 90.00$ per month.

BREEDS OF CATTLE.

\begin{tabular}{|c|c|c|c|c|c|c|}
\hline & $\begin{array}{l}\text { Coast } \\
\text { Div. }\end{array}$ & $\begin{array}{c}\text { Willam- } \\
\text { ette } \\
\text { Valley. }\end{array}$ & $\begin{array}{l}\text { Southern } \\
\text { Oregon. }\end{array}$ & $\begin{array}{c}\text { Columbia } \\
\text { Basin. }\end{array}$ & $\begin{array}{l}\text { Blue } \\
\text { Mts. }\end{array}$ & Central. \\
\hline 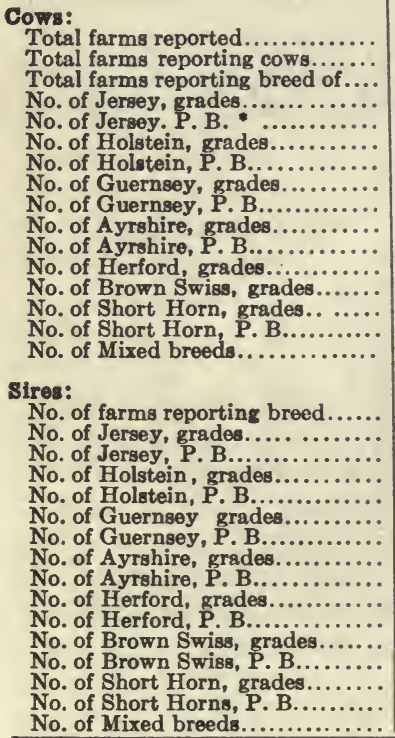 & 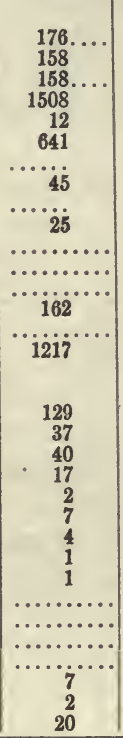 & $\begin{array}{c}556 \\
455 \\
446 \\
2106 \\
92 \\
200 \\
39 \\
46 \\
65 \\
43 \\
20 \\
\cdots 20 \cdots \\
237 \\
\ldots 333 \\
353\end{array}$ & 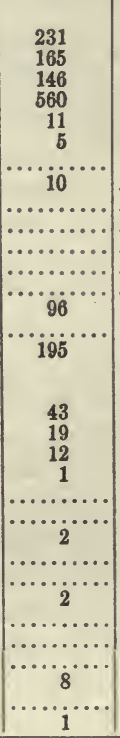 & 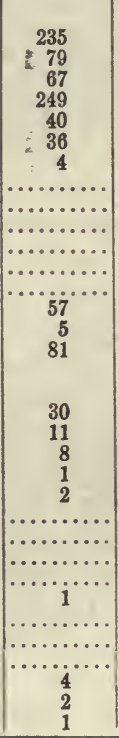 & 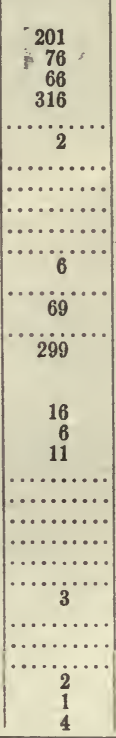 & 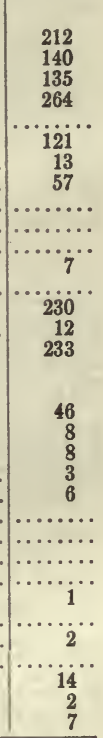 \\
\hline
\end{tabular}

*P. B. means pure bred.

In several cases two or more bulls were reported on one farm. 
A very undesirable condition of affairs with reference to dairy sires, is revealed by the table on the opposite page. It will be observed that in each of the six divisions, except the Willamette Valley division, the number of grade and mixed breeding (scrub) sires exceeds the number of pure bred sires. In the Coast division the pure bred sires are outnumbered two to one. The use of pure bred sires is the most potent factor in effecting improvement in the producing capacity of a dairy herd, and the dairyman who tries to economize by using an inferior bull is following a very short sighted policy.

Refcrence to the table will show a very large preponderance of Jerseys, among the grades as well as the pure breds. The Willamette division in particular is shown to be a decidedly Jersey district.

\section{NUMBER AND KINDS OF CREAM SEPARATORS.}

\begin{tabular}{|c|c|c|c|c|c|c|}
\hline - & $\begin{array}{l}\text { Coast } \\
\text { Div. }\end{array}$ & $\begin{array}{l}\text { Willam- } \\
\text { ette } \\
\text { Valley. }\end{array}$ & $\begin{array}{l}\text { Southern } \\
\text { Oregon. }\end{array}$ & $\begin{array}{c}\text { Columbia } \\
\text { Basin. }\end{array}$ & $\begin{array}{l}\text { Blue } \\
\text { Mts. }\end{array}$ & Central. \\
\hline 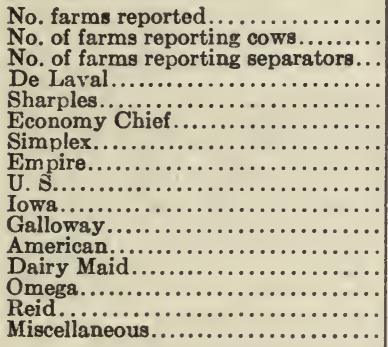 & $\begin{array}{r}176 \\
158 \\
90 \\
29 \\
16 \\
14 \\
15 \\
5 \\
3 \\
3 \\
4 \\
1 \\
1 \\
1\end{array}$ & $\begin{array}{r}556 \\
455 \\
303 \\
62 \\
72 \\
40 \\
32 \\
38 \\
26 \\
13 \\
2 \\
3 \\
4 \\
2 \\
3 \\
6\end{array}$ & $\begin{array}{c}231 \\
165 \\
83 \\
20 \\
23 \\
15 \\
9 \\
5 \\
7 \\
\ldots \ldots \\
2 \\
1 \\
1 \\
\ldots \ldots \ldots \\
1\end{array}$ & $\begin{array}{c}235 \\
79 \\
31 \\
13 \\
2 \\
11 \\
1 \\
\cdots \cdots \cdots \cdots \\
\cdots \cdots \cdots \\
1 \\
1 \\
1 \\
1\end{array}$ & $\begin{array}{r}201 \\
76 \\
39 \\
15 \\
4 \\
5 \\
6 \\
1 \\
3 \\
1 . \\
\ldots \ldots \\
1 \\
\ldots \ldots \ldots\end{array}$ & $\begin{array}{r}212 \\
140 \\
73 \\
22 \\
14 \\
15 \\
4 \\
5 \\
3 \\
1 \\
1 \\
1 \\
2\end{array}$ \\
\hline
\end{tabular}

Reference to the above table indicates to some extent the importance of the cream separator as a part of the dairy farm equipment. The use of the separator on farms selling the product to creameries is almost universal except in some parts of the Coast division, particularly Coos County, where whole milk is delivered to the creamery. In the cheese making districts there is not much use for the separator. The 49 farms reported in Tillamook County show only six cream separators.

The table shows something of the variety of cream separators now on the market. The "miscellnneous" portion of the tabulation represents nine different kinds oi separators in addition to the 12 individually listed.

Markets: The Oregon market for dairy products is one of the highest in the United States. Butter prices in Portland range from 3 to 6 cents higher than butter prices in Chicago, New York and other Eastern markets. The Portland price is also usually somewhat in advance of the San Francisco market. The state is well supplied with creameries, cheese factories and condensing establishments, so that the milk producer has little trouble in finding a ready sale for his product. Practically all milk and cream sold to 
factories of the various classes is sold on a butter-fat basis. Cheese factories and condensing establishments are able to pay a higher price for the fat than the creameries are, but there is a question in the minds of most milk producers as to whether the higher price compensates for the loss of the skim milk for feeding purposes. Prices paid for butter fat by one of the largest creameries in Western Oregon are shown in the following table:

BUTTER FAT PRICES.

\begin{tabular}{|c|c|c|c|c|}
\hline Month & 1909 & 1910 & 1911 & 1912 \\
\hline 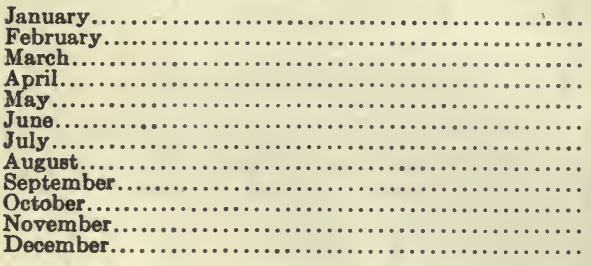 & $\begin{array}{l}\$ 0.37 \\
.343 \\
.36 \\
.28 \\
.261 \\
.263 \\
.28 \frac{1}{2} \\
.31 \frac{1}{31} \\
.35 \frac{1}{2} \\
.36 \\
.36 \\
.40\end{array}$ & $\begin{array}{l}50.40 \\
.40 \\
.38 \\
.321 \\
.28 \\
.29 \\
.301 \\
.341 \\
.36 \\
.37 \\
.371 \\
.10\end{array}$ & $\begin{array}{l}80.40 \\
.353 \\
.32 \\
.271 \\
.24 \\
.231 \\
.26 \\
.27 \\
.30 \\
.32 \\
.351 \\
.36\end{array}$ & $\begin{array}{l}80.38 \\
.36 \\
.34 \\
.33 \\
.27 \\
.28 \\
.293 \\
.32 \\
.33 \\
.362 \\
.37 \\
.39\end{array}$ \\
\hline Average $\ldots \ldots \ldots \ldots \ldots \ldots \ldots \ldots$ & .83 & $.35 t$ & $.30 t$ & $.33 \frac{1}{2}$ \\
\hline
\end{tabular}

The sale of surplus stock is an important source of income for the Oregon dairy farmer at the present time. The farmers in the Eastern portion of the State, being unable to get sufficient stock in the Western portion to supply the needs of a rapidly developing dairy section are sending representatives into Wisconsin, Illinois, and Iowa to secure foundation stock. Such Oregon dairymen as have stock for sale arc receiving most satisfactory prices.

The statement is sometimes made that the higher prices of feed stuffs in Oregon in a large measure offset the gain due to the higher price at which dairy products are sold, when comparison is made with Middle West conditions. While it is true that some of the concentrated feed stuffs are higher, a lower value should be assigned to hay, roots, and other coarse fodder, and the mild climate, particularly in the Western portion of the State, permits of a longer growing season-in fact, the growing of certain crops, kale, for instance, throughout the winter. The importance of dairying in connection with fruit growing is just beginning to be realized. Particularly is this true in the case of the small fruits. On most soils suited to small fruit production, fertilization soon becomes necessary, and stable manure is well suited to this use. One prominent small fruit grower says that the fertilizer produced by his cows fully pays for the feed and care of the animals so that the value of the dairy product may be regarded as all profit.

Acijectives are scarce in this book. It was not written to entertain but to present hard facts. 


\section{SOILS AND FARM CROPS IN OREGON.}

BY H. D. SCUDDER,

Professor of Agronomy.

\section{CONTENTS.}

1. Types of Farming in Oregon........................ Pages $33-35$

2. Selecting a Farm in Oregon.......................... Pages $35-46$

3. The Soils of Oregon..................................... $46-52$

4. The Farm Crops of Oregon............................... $52-63$

\section{TYPES OF FARMING IN OREGON.}

$\mathbb{C}^{\mathrm{n}}$ $\mathrm{HE}$ agricultural wealth of Oregon is derived very largely from its fields of grain and hay and from its livestock and dairy farms. The greater share, perhaps 90 per cent, of the tillable acreage of the state is better adapted to the growing of the common field crops than for any other use. Selected areas in many parts of the state have great advantages in soil and climatic conditions for the production of the various fruit and truck crops. Oregon has become so widely known, and properly so, as a grower of high grade fruits that it is only recently that the newcomer to the state has learned of equally advantageous conditions for the production of other crops.

A glance at the agricultural production of Oregon for 1912 will show that the great majority of the farming population of the state is employed in the growing of the staples of agriculture-field crops and livestock.

\section{AGRICULTURAL PRODUCTS IN OREGON IN 1912.}

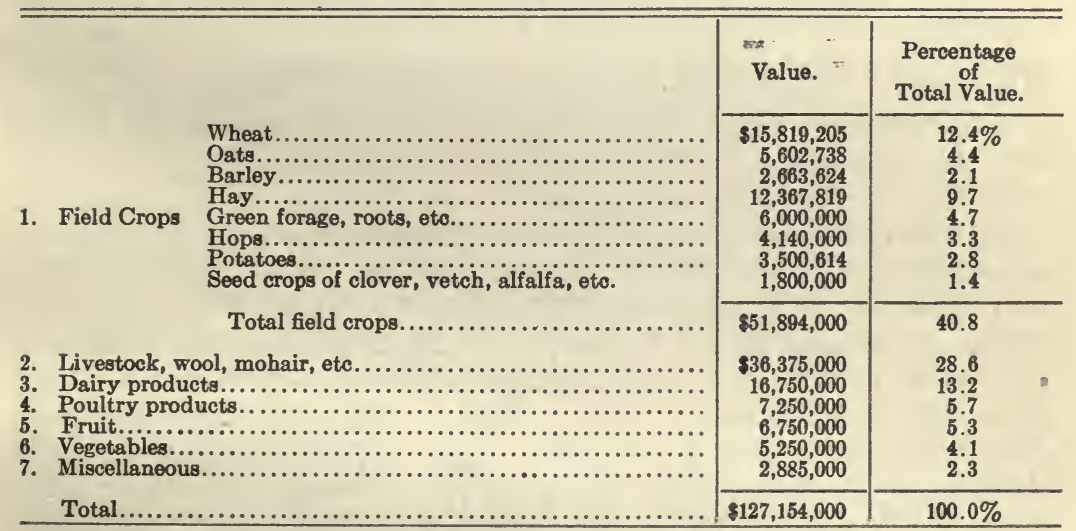

Because of the diversity in climate, soil, topography, transportation facilities, market conditions, and in the price of land, in the different portions of the state, nearly every type of farming common to the United states is successfully carried on in Oregon. Grain, hay, dairying, all classes of livestock (both under range and farm conditions), poultry, fruits, truck-all of these types, singly, or in 
every possible combination, are found. The most frequent specialized types of farming (where just one crop is produced) are: Wheat farming, cattle ranging, sheep ranging, fruit growing and perhaps dairying. The most frequent diversified types are: (1) Field crop and livestock combinations; (2) Dairy farming combinations; Diversified field crop production.

Of the types of farming named, those which offer the surest returns and the widest opportunity for success to the average farmer are well balanced combinations of the field crops together with a certain amount of any of the classes of livestock or forms of dairy production-diversified farming, in short, on a moderately and increasingly intensive basis. Examples of combinations for diversified farming well adapted to securing the highest and most permanent profits in the different natural divisions of the state are suggested below.

\section{Coast Division.}

(1) Diversified Dairy Farming - On the bottoms and tidelands or the red hill lands, for the production of cheese and butter. This is undoubtedly the most profitable type for this region, which is richly endowed for this kind of production.

(2) Diversified Livestock Farming-Cattle and sheep grazing on the hills with grain and hay in the valleys. The large areas of steep hill land offer the best of grazing throughout the year because of the summer rains and absence of winter snow, while the richness of the many small valleys permits maximum grain and hay crops.

(3) Truck or Small Fruit Farming-Certain classes of truck on the rich tidelands and of small fruit on selected hill lands are very successfully produced.

\section{Willamette Valley and Southern Oregon Divisions.}

(1) Diversified Field Crop Farming-Potatoes, grain and clover seed, for example. A very profitable type where livestock is not desired.

(2) Diversified Crop and Livestock-(a) Grain and hay, sheep or cattle; (b) Grain and forage, hogs and sheep. Both of these types are unusually profitable ones where properly carried out.

(3) Diversified Dairy Farming - (a) Butter, cream or milk production in combination with hogs or chickens or both, with hay, grain, soiling crops and pasture. This is one of the most common, surest and most widely successful types for these divisions. Dairying and small fruits-an especially profitable type for small farms on high priced land. (c) Dairying in combination with hogs and the growing of cash crops such as potatoes or clover seed. Excellent where so many cows are not desired.

(4) Fruit Growing-Diversified and Specialized-In no part of the state or Northwest are superior conditions found both as to climate and soil for fruit growing than in the Willamette Valley or Southern Oregon on selected areas. 
(5) Truck Farming-(a) Diversified; (b) Truck in combination with fruit growing. Limited areas and certain soil types are especially adapted to the growing of the more profitable truck crops such as onions, celery, etc.

(6) Poultry Farming-Diversified or specialized or in combination with dairying and small fruits. Exceptional market demand makes any form of poultry production, properly managed, successful.

Columbia Basin, Blue Mountain and Central Oregon Divisions.

(1) Diversified Grain and Legume Seed Production-On dry farming lands where livestock is not desired.

(2) Diversified-Grain, Forage, Hogs and Horses-A still better type for the dry farming lands.

(3) Diversified-Grain, Legume Seed, Forage, and Hogs or Sheep and Poultry - An equally good type for the dry farming lands and good also on the irrigated lands.

(4) Diversified-Grain, Forage and Hog Production-A profitable type for both the dry farms and the irrigated farms.

(5) Diversified-Dairy Farming with Hogs and Poultry-The best type for the irrigated lands.

(6) Diversified Fruit Production-On the irrigated lands in selected areas in the Columbia Basin and Blue Mountain divisions.

\section{Selecting The Type.}

\section{SELECTING A FARM IN OREGON.}

Of course, the type of farming to be selected must be determined largely by the personal experience, inclination and capacity of the individual for any certain line of production. From the economic standpoint, however, the capital required, the length of time before returns are received, the relative risks of failure involved, the chances for increased valuation of the property, the labor requirements for the different types-all must be considered in selecting the kind of farming to be undertaken. These points settled, a careful survey of the conditions in the different districts of the state as to the soil, climate, topography, transportation facilities, markets, community advantages, labcr supply, prices of land, etc., will disclose those sections where the largest number of these factors faror success for the particular type of farming chosen.

\section{Selecting the Region.}

Most newcomers as a rule give too little consideration to the relative advantages of the different sections of the state for the type of farming they wish to undertake. No matter what type is selected, no farmer need fail in Oregon if due care is used in selecting the most suitable section for his purpose. No better investment of a portion of the newcomer's capital can be made than in a careful examination of the chief farming districts, and then of the district itself for the individual land. 


\section{Change in Climate.}

In studying the various districts themselves, and as they are shown in tables of results herein, the climatic conditions will be found to play a very important part in the variation in production observed. Since very misleading statements are often expressed regarding "changes in climate" supposed to take place, it is well to state here that the climate of any locality does not change. A very common fallacy in new countries is the belief that the climate will alter, rainfall increase and frosts decrease with the change brought about by putting land under cultivation or irrigation, while in old settled countries it is very commonly stated that the climate is changing. Both of these ideas have been repeatedly proven untrue by the most authoritative and indisputable records of accurate weather observations. Precipitation and frosts in a region are not altered by cultivation or irrigation. In very small confined local areas, night temperatures may be slightly altered but never sufficiently to be of practical importance as far as crops are concerned. Nor does the climate grow steadily worse or steadily better. Weather varies greatly from year to year but there is an average or normal weather condition that may be depended upon to prevail the majority of years.

\section{Climatic Considerations.}

The important climatic considerations as affecting the production of a region are, normal total precipitation and its distribution through the year, (especially during the seeding and growing and harvest seasons), and frosts, (as regulating the length of season). The effect of the Japan current on the westerly winds and the great variation in the topography of the state are the chief factors causing Oregon's unusual climatic features and the wide climatic variations between the different regions. (Data for different districts of the state are given elsewhere). See page 65. Oregon is largely free from the torrential rains which cause floods and injurious soil erosion-free from injury by hard and violent winds-noted for her cool nights in summer, and, in Western Oregon especially, for the great mildness of all winter and summer temperatures and the exceptionally long growing seasons. The rainfall varies widely -it is heavy on the coast, ample in the Western Oregon interior, less in Southern Oregon, and scanty in the Columbia basin and Central Oregon, increasing again in the Blue Mountain region. The distribution of rainfall for spring seeding is good throughout the state, and for fall seeding excellent, except in portions of the Columbia Basin where it generally comes a little late. For the harvest of hay and grain the conditions are ideal, but for summer crops the precipitation is a little too light in the summer months unless thorough cultivation is given.

The temperature is mildest and the growing season longest on the coast, mild and long in the Willamette Valley, shorter in Southern Oregon as the elevation increases, still shorter in the Columbia Basin and Blue Mountain region, and shortest in Central Oregon 
at the higher elevations, so that in that district only the hardier crop varieties may be grown.

\section{Getting Started Right.}

Upon a wise selection of the farm itself more than on anything else, depends the farmer's opportunity for success. There are, in each district in the state, farmers who are always prosperous, who get paying crops in "off" years and good crops in ordinary years, who live in comfortable homes, and send their sons and daughters to college. These are the farmers who have selected a type of farming fitted to their individual capacities and chosen a region suitable to that type and then have located the right farm on which to carry out their plan. Other farmers in the same community will spend a lifetime working against unfavorable odds because of the poor selection of the type of farming, of land, or of methods.

\section{Size of Farm.}

A common mistake in purchasing a farm is selecting too large a size for the type of work to be done, investing too much of the capital in land and reserving an insufficient amount for equipment and operation. The successful modern farmers in Oregon are almost universally those who select the smaller farms, work them more intensively, and diversify their production. The newcomers to Oregon who fail are more often those who speculate in farm lands. The man who comes to Oregon as a speculator in land is in nearly all cases less successful than the man who comes to farm the land. Individual farm values here increase largely as production on the individual farm increases. Poorly farmed land increases in value slowly or not at all. The good farmer gets the double profits of successful production and increased land value. This means that the best opportunity in both directions lies with the farmer who selects the number of acres best adapted to his type of farming.

On the more successful Oregon farms of the different types the gross profits per acre and the best sizes of farms from which to get such profits are about as follows:

BEST SIZE OF FARM (CROPPING AREA) FOR DIFFERENT TYPES. On Basis of Annual Gross Income of $\$ 4000$.

\begin{tabular}{|c|c|c|c|c|}
\hline \multirow{2}{*}{ Type. } & \multicolumn{2}{|c|}{$\begin{array}{l}\text { Gross Income } \\
\text { per Acre. }\end{array}$} & \multirow{2}{*}{$\begin{array}{l}\text { Size of } \\
\text { Cropping } \\
\text { Area. }\end{array}$} & \multirow{2}{*}{$\begin{array}{c}\text { No. of } \\
\text { Work } \\
\text { Horses. }\end{array}$} \\
\hline & Ave. & High. & & \\
\hline 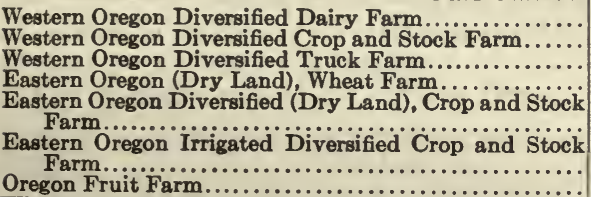 & $\begin{array}{r}50.00 \\
40.00 \\
150.00 \\
7.00 \\
12.00 \\
40.00 \\
200.00\end{array}$ & $\begin{array}{r}\$ 100.00 \\
70.00 \\
300.00 \\
15.00\end{array}$ & $\begin{array}{l}80 \text { acres. } \\
100 \text { acres. } \\
25 \text { acres. } \\
640 \text { acres. } \\
320 \text { acres. }\end{array}$ & $\begin{array}{r}4 \\
5 \\
2 \\
12\end{array}$ \\
\hline
\end{tabular}

The most successful farms are those of sufficient size and diversity of production to keep the farmer and his horses busy throughout the year, securing the best efficiency in the use of capital, labor, horses and machinery. Twenty to thirty acres per horse is the 
range for the most profitable production with modern machinery except on the dry farming lands, where larger acreage per horse is possible.

The purchase of larger sized farms than those given above would in most cases be justified only on the basis of the speculative value of the land or, too extensive a form of farming to get the best permanent results or the highest profits per acre.

\section{Examining tho Prospective Purchase.}

The proportion of land on the farm adapted to the kind of farming to be done, the shape and size of the fields as adapted to economy in cultivation and for fitting into a rotation, the convenience of location of the farmstead to the fields-all these must be considered. The fewer division fences, the less chopped up and irregular the fields are, and the closer the farmstead is to the center of the farm, the better. The topography is very important both as to the absolute elevation above sea level and the relative elevation above surrounding lands. After elevation increases above 2500 feet the growing seasons become markedly shorter and frosts more frequent. The relative elevation above surrounding lands as affecting the air drainage bears upon the protection from local frosts and in Western Oreyon especially, bears upon the natural drainage of excess moisture. Only a little slope is needed as a rule to give good natural water drainage. The exposure of the slope as far as temperature is concerned is less important in Oregon than in more extreme climates but the soil on the hill lands in this state varies considerably with exposure, being quite commonly less good in quality on the south slopes, especially where the slopes are more steep. In some regions in Eastern Oregon and along the coast the exposure of the slope also bears upon the protection from strong winds.

The natural drainage of the land for excess moisture should be given careful attention especially in Western Oregon where the rainfall is very heavy and in Eastern Oregon where the land is irrigated and through seepage, may become "alkalied". Where artificial drainage is required the cost per acre should be considered in judging the value of the land.

The condition of the land as to cover of brush, stumps, stones, weeds, etc., should be given special attention. Too frequently Eastern farmers unaccustomed to timber or other cover greatly under-estimate the cost of clearing. It is often better to buy land already cleared. When land is not cleared the price should be correspondingly much lower. Clearing sagebrush land in Eastern and Central Oregon costs about $\$ 5$ per acre, juniper land $\$ 15$ per acre, and in Western Oregon oak grub land or cut-over timber land from $\$ 50$ to $\$ 100$ per acre.

Of all the points considered in selecting a farm, the most important is the fertility of the soil, and by this is meant the natural fertility. Building up the farm with commercial fertilizers and otherwise increasing the fertility through artificial means is costly and slow and greatly reduces the profits in farming. Nor does the artificial 
fertility induced ever fully take the place of natural fertility. Oregon farming lands for the most part have great natural fertility. This is of special importance to the general farmer who must depend mainly upon natural fertility rather than upon costly commercial fertilizers. While some Oregon farms because of poor drainage or long abuse have soils that are out of condition, they are not out of fertility, even though the present crop yields are low. The soils are neglected, not poor, and with good tillage methods and rotations or a little under drainage or liming, quickly respond. There are very few soil types or areas in the state that could be called poor or worthless.

So then, before the farm is purchased the soil should be examined most carefully for fertility. Soil survey maps of the state or government should be used where obtainable as they give a great deal of valuable information, but unfortunately Oregon has no state soil survey as yet and government maps are for very limited areas only. Such as there are, can be secured by writing the Bureau of Soils, Washington, D. C.

The crops growing upon the land, if there be such and if all the conditions as to season, treatment, etc., are normal, should of course give considerable information as to the fertility of the soil, but in many cases the crop is not a sure guide; nor on the other hand can any man, no matter how wise he be, determine the fertility from the character of the natural vegetation, especially by the presence or absence of any one plant. Oaks four feet through will sometimes be found on soil only a foot and a half deep. However, the natural vegetation does give some indication of quality. Soils on which the pines grow and other trees do not, are as a rule inferior in quality, while soils where the basswood, walnut, ash and maple grow well, are generally of the best quality. On the Western Oregon hill lands a dense growth of vigorous scrub oak is generally a good indication, while a light scattering growth usually means lack of depth or quality. The growth of fir seems to be regulated more by the moisture conditions than by other soil qualities. On the hills the growth of the "fern" or brake is often deceiving. A very heavy growth will generally indicate merely a greater abundance of moisture from seepage, and a light growth does not by any means indicate a lack of fertility. In Eastern Oregon a dense growth of heavy black sage indicates the better, more fertile soils, while the absence of this brush and the presence of greasewood, saltbush and saltgrass indicate poor natural drainage and the presence of excessive alkali. Sedges or slough grass mixed with other grasses in a field indicate poor under drainage. The poor growth of the clovers and the presence of an abundance of sorrel and moss indicate, in Western Oregon, acid soils in need of lime, while along the coast the growth of huckleberries, blueberries and salal brush to the exclusion of others indicates lack of lime.

The color of the soil is generally a fair indicator of fertility, the darker red or darker gray or brown shades indicating the richer soils. A black color, however, does not always indicate great 
fertility. The soil should be seen dry as well as wet as nearly always it becomes darker and richer looking when wet. The darker a soil becomes on wetting the richer it is as a rule.

Chemical and physical analyses of soils are of service in aiding the scientist in judging fertility. They are of little value to the farmer who cannot interpret them. Unfortunately, chemical analysis cannot show the availability of the plant food contained in the soil. It is chiefly valuable in showing a marked deficiency in the total supply of any important element in soils where some deficiency is apparent. A physical analysis is more readily interpreted and in most cases is of greater value, as it determines the proportion of the mechanical components in a soil and thus bears immediately on the aeration and drainage and upon the chemical and bacterial activities which have so much to do with the rate at which plant food becomes available. Physical analysis shows also the ease of handling and the crop adaption possibilities of a soil. The interpretation of a soil expert familiar with the soil and other conditions in the different localities of the state, is necessary, to make any analysis of the greatest value. The best thing for the newcomer who is in doubt about the fertility, value and use of a soil in which he is interested, is to take with considerable care, pint samples representing the average surface soil to a depth of 10 inches and the average subsoil to a depth of 30 inches, and send these with a complete description of the land, its exact location, topography, previous cropping, sub-strata, etc., to the Soil Department of the State Experiment Station for examination and advice.

In no case should the farmer fail to make borings with a post hole augur or spade to determine the character of the subsoil, depth to rock, gravel, "soapstone", or other underlying strata-presence and character of hardpans, distance to standing water in poorly drained land, etc. There is no man so expert in judging fertility who can estimate it by looking at the surface soil alone. Subsoil conditions are seldom indicated by surface appearances. For many forms of production the depth and character of the subsoil is more important than anything else. In Western Oregon the depth of soil and natural drainage are the most important points to be observed, and in Eastern and Central Oregon-degree of sandiness, hardpan, and drainage, as indicated by alkali excess. Presence of alkali is readily shown during the summer months by brownish stains or whitish salts- by "slick" spots where the soil is badly run together and cracked, or by saltgrass or greasewood and the absence of black sage.

The physical character of the soil-its lightness or heavinessaffects farming operations more than any other single feature-in ease of soil handling, earliness of seeding and quickness in maturing; as well as in retentiveness of plant food and moisture or the opposite, inclination toward acidity, the kinds of crops best adapted, etc. Hence, the physical qualities should be given close attention in selecting the land.

The climatic conditions on the individual farm must also be considered. A slight elevation on the long, gently sloping flanks of 
the hills in Central Oregon where the soil is of good depth, often gives sufficient air drainage to protect field crops from killing frosts, while the level lands one-half mile away, will suffer. In this same section a slight relative elevation often gives additional precipitation or extra moisture from seepage, etc., while in other parts of the state the elevation makes an especially great difference in the frost protection of fruits. Individual farms may differ considerably as to wind exposure, affecting fruit trees, or evaporation or soil blowing, etc.

Healthfulness in the selection of an Oregon farm is not a factor. There is probably not an unhealthful location in the state.

Marketing conditions must be carefully considered. Is there a good local market for products raised or for buying supplies? What is the distance to haul? Hauling costs vary immensely with different products. Some products, such as alfalfa seed, can be hauled one hundred miles where for others such as hay all the profits would be consumed in only a few miles. Distance alone does not regulate the cost of hauling. The character of the roads as to surface, grade and drainage is even more important. Road conditions in Oregon, however, are rapidly improving. Transportation and shipping facilities to the more distant markets-freight rates, frequency of train service, number of transfers, warehouse accommodations, terminal facilities, etc., should be observed. The opening of the Panama Canal will undoubtedly do a great deal for the Oregon farms in bringing them nearer to the eastern or foreign markets. The great development of electric railroads in Western Oregon in the last few years and the extension of the steam railroads to Central Oregon have effected great improvements for both the long and short hauls of the farmer's goods.

The labor supply of the locality should not be overlooked. In most districtsit is reasonably good and promises to be much improved with the influx of immigrants with the opening of the Canal. Farm wages are not unduly high even at the present time. (See Table 2, page 44.)

Community conditions play an important part in the selection of a farm. Co-operative organizations for the growing, advertising, preparation for market, storing, selling and shipping of products, as well as for the buying of supplies are essential for nearly every form of production, whether it be apples, cows, onions, grain or other goods. The Oregon farmer has made a good beginning in the matter of co-operation, is fully aroused, and well in advance of most of the other states in the Union in this modern development. The social and business conveniences of the community and the living cost are also factors in the selection of the farm.

Water for livestock and domestic use is often one of the most costly necessities on the farm. The average depth of wells in the different districts of Oregon is shown in Table 2, page 44. It varies locally in the Columbia Basin and Central Oregon more than elsewhere, all the way from 20 to 500 feet. Throughout Western Oregon, water of fine quality is easily obtained from springs, streams or wells.

The fertility of the soil and the location for marketing are the two most vital factors so far discussed; the third, is the amount and 
character of improvements. As a rule both extremes, either the farm that is altogether unimproved or the opposite case, one that is over improved, are over-valued or over-priced. A good house is the most important building improvement to seek. It can generally be purchased more cheaply than built. Costly farm houses, however, may be out of proportion to the capital invested in the rest of the farm, for they produce no income. Comfort and modern conveniences, in any case, are an essential part of modern rural life that any farmer can have if his business success justifies it. Other farm buildings are desirable only if suitable. Otherwise, they are of little value. Oregon farms are as yet rarely over-loaded with building improvements. Good buildings on good land are generally bought at their real value. Good buildings on poor land are valued too high.

The kind, condition and arrangement of fences is important. Good woven wire boundary fences are a valuable part of the purchase. Rail or other inferior fences are often purchased at a loss, as are also division fences. Such fences waste land, increase labor and harbor pests and in modern systems must be removed.

In Western Oregon most farms have the advantage of a wood lot thrown in at no cost. Wood is especially valuable where located on waste land so that it does not mean eventual cost of clearing.

Good family orchards are very common and effect an important saving in the living cost.

The acreage and quality of the area of the farm actually under cultivation or cleared should be used in determining the real price per acre. Waste land should be cut out entirely in figuring the price. It generally will do no more than pay its own taxes. All undrained land or poorly drained or alkali spots should also be eliminated or cost of reclamation included in figuring the real value per acre compared with the price asked. Little money should be paid for waste land and uncleared or unreclaimed areas should be figured correspondingly low. In irrigated lands the amount, cost, upkeep, and right to water, and danger of alkali, should be considered.

Land in Western Oregon to which one is a stranger should be examined in March when bare and the physical conditions and the drainage are easily discerned. Land in Eastern or Central Oregon should be examined in July - at the dryest season and during harvest. Known land should be examined at harvest time and the character of the season and the weather should be taken into consideration. Never should land be purchased after only one trip of inspection. A second inspection alone, from a different direction, always pays. The conditions on surrounding lands, crop yields obtained and opinions of neighbors will often disclose additional facts.

It should be remembered that land values are variable within relatively short distances. Advertising often creates high prices in certain sections. Often land equally as good a short distance away may be found at much lower prices.

Buy on real value as guaged by production, not on trading or speculative value. Study a region or even live in it a while before buying. The 
writer has often advised newcomers to hire out or rent a farm in a region a year before buying.

Land values in different divisions are shown according to the U. S. census and for representative farms as determined by the Agricultural Survey (see Table 1, below). The price varies largely as the location is close in or further out.

Improved dairy land or diversified crop or stock farming land or fruit land unplanted (as good as there is, as far as productivity is concerned) may be purchased in Western Oregon at from $\$ 50$ to $\$ 150$ per acre, depending on the location and improvements. Truck land may be purchased for from $\$ 100$ to $\$ 200$, and irrigated land in Eastern Oregon for from $\$ 50$ to $\$ 150$.

The best homestead lands are already taken.- Most of the remaining homestead lands are in Central Oregon. There is practically no homesteading land in Western Oregon. Most homesteads are worth what the owner makes of them. In many cases, though not all, the homesteader who has a small amount of money and good farming ability would do better to invest it in deeded land or in renting land until his capital is increased. From tenant to owner is a change that takes place rapidly in Oregon. Rental terms are reasonable and crop conditions steady, so that renting is an attractive opportunity for the farmer of small capital as it permits the handling of far larger acreage and operations than would the same capital invested in his own land. See Table 2, page 44.

PRESENT OCCUPATION OF LANDS IN OREGON.

Table 1.

(U. S. Census).

\begin{tabular}{|c|c|c|c|c|c|c|c|c|c|}
\hline Division. & 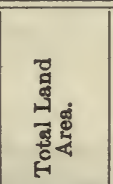 & 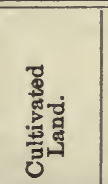 & 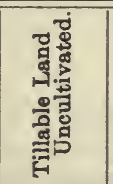 & 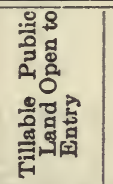 & 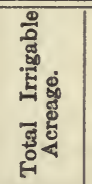 & 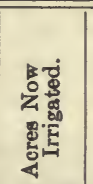 & 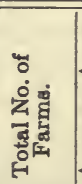 & 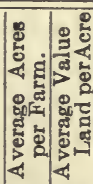 & 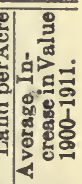 \\
\hline $\begin{array}{l}\text { Coast.............. } \\
\text { Willamette Valiey } \\
\text { Southern Oregon. } \\
\text { Columbia Basin.. } \\
\text { Blue Mountain... } \\
\text { Central Oregon... }\end{array}$ & $\begin{array}{r}3,891,200 \\
8,875,520 \\
6,085,760 \\
6,477,440 \\
9,290,240 \\
26,568,320\end{array}$ & \begin{tabular}{r|}
46,004 \\
$6,059,064$ \\
216,387 \\
$1,592,503$ \\
386,289 \\
791,857
\end{tabular} & $\begin{array}{l}1,291,629 \\
2,517,941 \\
2,202,112 \\
1,879,679 \\
1,976,770 \\
9,483,108\end{array}$ & $\begin{array}{r}2,842 \\
41,502 \\
102,234 \\
234,321 \\
5,827,646\end{array}$ & $\begin{array}{r}77,98 \mathrm{i} \\
81,164 \\
261,743 \\
149,588\end{array}$ & $\begin{array}{r}300 \\
500 \\
42,813 \\
26,742 \\
247,196 \\
356,714\end{array}$ & $\begin{array}{r}3,401 \\
22,748 \\
4,693 \\
5,592 \\
4,831 \\
4,237\end{array}$ & \begin{tabular}{|l|l|}
196 & $\$ 34$ \\
130 & 76 \\
196 & 53 \\
$* 676$ & $* 22$ \\
503 & 22 \\
607 & 20 \\
\end{tabular} & $\begin{array}{l}6177 \% \\
6183 \% \\
3220 \% \\
2231 \% \\
215 \% \\
2238 \%\end{array}$ \\
\hline State Total.... & $|61,188,480|$ & $4,092,104$ & $19,452,129$ & $6,158,555$ & 830,527 & 686,129 & 45,502 & $256 \$ 35$ & $5206 \%$ \\
\hline
\end{tabular}

Present Occupation of Lands in Oregon. (Table 1, above).

This table shows at a glance the acreage in the state that is tillable -23,500,000 acres - and the large proportion of this still unplowedabout $80 \%$-also the considerable area of tillable public land still open for entry. The large amount of land that is irrigable and the proportion of this now under water speaks well for the development of this phase of farming. It should be understood that while small areas in the Willamette Valley and Coast regions are irrigated, that irrigation in these districts is not at all necessary for maximum production but that in very intensive forms of farming such as truck gardening, irrigation may be used with profit even in these humid regions. 


\section{Is there Room for You in Oregon?}

The extremely small number of farms and the large size of the same shows very distinctly the accommodations the state has to offer for a great increase in its farming population. Tillable land nearly $24,000,000$ acres and number of farms only 45,000 are two figures that explain a great deal as to the opportunity for further agricultural development and the reason for $80 \%$ of the tillable land being uncultivated.

Comparing the number of farms in the Willamette valley with the number in other regions of equal or greater tillable areas, Central Oregon for instance, shows at once where the land has been most fully settled and where the greatest development is yet to take place. It should be remembered, too, that the sizes of farms as shown are in most cases in all regions, twice as large as is desirable for the most profitable forms and methods of production. This and the large proportion of tillable land still uncultivated accounts for the extremely low prices of land in all regions of the state, notwithstanding the increase in value shown for the past decade.

With the facts shown in this table and elsewhere and a full knowledge of the possibilities for agricultural production in all parts of the state - it is not too much for anyone to say that there is ample opportunity in Oregon for five or even ten times its present farming population and with even greater prosperity for all than her present peoples enjoy. With the continuing westward trend of the farming population of the United States, with the added influx through the Canal, and with Oregon on the very shores of the Pacific-it is not too much to believe that the state will double the number of its farmers within the next five years.

\section{MISCELLANEOUS DATA.}

From Agricultural Survey of Representative Oregon Farms.

(Note: The columns headed "No. Rep." indicate the number of farms Table 2. reporting on each subject tabulated.)

\begin{tabular}{|c|c|c|c|c|c|c|c|c|c|c|}
\hline \multirow{2}{*}{ Division. } & \multicolumn{4}{|c|}{$\begin{array}{l}\text { Average Rental For General } \\
\text { Farms. }\end{array}$} & \multicolumn{2}{|c|}{$\begin{array}{l}\text { Average Clear- } \\
\text { ing Cost. }\end{array}$} & \multicolumn{2}{|c|}{$\begin{array}{l}\text { Average Depth } \\
\text { of Wells. }\end{array}$} & \multirow{2}{*}{\multicolumn{2}{|c|}{$\begin{array}{l}\text { Average No. } \\
\text { Work Horses } \\
\text { per Farm. }\end{array}$}} \\
\hline & $\begin{array}{l}\text { No. } \\
\text { Rep. }\end{array}$ & $\begin{array}{c}\text { Cash } \\
\text { per }\end{array}$ & $\begin{array}{l}\text { No. } \\
\text { Rop. }\end{array}$ & Share. & $\begin{array}{l}\text { No. } \\
\text { Rep. }\end{array}$ & $\begin{array}{l}\text { Per } \\
\text { Acre. }\end{array}$ & $\begin{array}{l}\text { No. } \\
\text { Rep. }\end{array}$ & $\begin{array}{l}\text { Depth } \\
\text { in } \mathrm{ft} .\end{array}$ & & \\
\hline $\begin{array}{l}\text { Coast....... Vail...... } \\
\text { Willamette Viley... } \\
\text { Southern Oregon.... } \\
\text { Columbia Basin .... } \\
\text { Blue Mountains..... } \\
\text { Central Oregon...... }\end{array}$ & $\begin{array}{r}14 \\
129 \\
\cdots 9 \\
20 \\
27\end{array}$ & $\begin{array}{r}\$ 8.00 \\
5.50 \\
\because \% .30 \\
6.00 \\
4.00\end{array}$ & $\begin{array}{r}1 \\
69 \\
3 \\
90 \\
6 \\
65\end{array}$ & $\begin{array}{r}1 / 3 \\
1 / 3 \\
1 / 3 \\
1 / 3 \\
1 / 3-1 / 2 \\
1 / 4\end{array}$ & $\begin{array}{r}98 \\
170 \\
40 \\
16 \\
31 \\
148\end{array}$ & $\begin{array}{r}\$ 80.00 \\
55.00 \\
53.00 \\
35.00 \\
13.00 \\
6.00\end{array}$ & $\begin{array}{r}66 \\
323 \\
23 \\
142 \\
77 \\
184\end{array}$ & $\begin{array}{l}22 \\
36 \\
21 \\
69 \\
23 \\
45\end{array}$ & $\begin{array}{r}4 \\
4 \\
3 \\
12 \\
7 \\
8\end{array}$ & $\begin{array}{l}4 \\
3 \\
3 \\
3 \\
3\end{array}$ \\
\hline State Average.... & & $\$ 6.00$ & & $1 / 3$ & & $\$ 46.00$ & & 33 & 6 & 8 \\
\hline \multirow[t]{2}{*}{ Division. } & \multicolumn{2}{|c|}{$\begin{array}{l}\text { A verage Acres } \\
\text { Irrigated. }\end{array}$} & \multicolumn{2}{|c|}{$\begin{array}{c}\text { Average per } \\
\text { cent Using } \\
\text { Irrigation. }\end{array}$} & \multicolumn{2}{|c|}{$\begin{array}{c}\text { Average per } \\
\text { cent Using } \\
\text { Rotation. }\end{array}$} & \multicolumn{2}{|c|}{$\begin{array}{l}\text { Average Amt. } \\
\text { Manure used. }\end{array}$} & \multicolumn{2}{|c|}{$\begin{array}{c}\text { Average Crop } \\
\text { Sales } \\
\text { Per Acre. }\end{array}$} \\
\hline & $\begin{array}{l}\text { No. } \\
\text { Rop. }\end{array}$ & Acres. & & Cent. & \#Per & Cent. & $\begin{array}{l}\text { No. } \\
\text { Rop. }\end{array}$ & $\begin{array}{l}\text { Loads per } \\
\text { Farm. }\end{array}$ & No. & Amt. \\
\hline $\begin{array}{l}\text { Coast.................. } \\
\text { Willametto Valiey.... } \\
\text { Southern Oregon..... } \\
\text { Columbia Basin...... } \\
\text { Blue Mountains...... } \\
\text { Central Oregon...... }\end{array}$ & $\begin{array}{l}128 \\
120 \\
158 \\
135 \\
\end{array}$ & $\begin{array}{r}332 \\
65 \\
142 \\
312 \\
\end{array}$ & & $\begin{array}{l}75 \\
53 \\
48 \\
81 \\
66\end{array}$ & & $\begin{array}{l}40 \\
65 \\
28 \\
8 \\
18 \\
15 \\
\end{array}$ & $\begin{array}{r}145 \\
412 \\
197 \\
17 \\
19 \\
158 \\
\end{array}$ & \begin{tabular}{|r|}
76 \\
103 \\
55 \\
41 \\
118 \\
85 \\
\end{tabular} & \begin{tabular}{|c|}
47 \\
404 \\
139 \\
158 \\
109 \\
153 \\
\end{tabular} & $\begin{array}{r}8.33 \\
13.46 \\
13.57 \\
8.86 \\
9.88 \\
13.17 \\
\end{array}$ \\
\hline State Average...... & & 110 & & 49 & & 29 & & 90 & & 11.17 \\
\hline
\end{tabular}


Table 2-Continued.

\begin{tabular}{|c|c|c|c|c|c|c|c|c|}
\hline \multirow{3}{*}{ Division. } & \multicolumn{8}{|c|}{ AVERAGE WAGES. } \\
\hline & \multicolumn{4}{|c|}{ With Board. } & \multicolumn{4}{|c|}{ Without Board. } \\
\hline & $\begin{array}{l}\text { No. } \\
\text { Rep. }\end{array}$ & Day. & $\begin{array}{l}\text { No. } \\
\text { Rep. }\end{array}$ & Month. & $\begin{array}{l}\text { No. } \\
\text { Rep. }\end{array}$ & Day. & $\begin{array}{l}\text { No. } \\
\text { Rep. }\end{array}$ & Month. \\
\hline $\begin{array}{l}\text { Coast................. } \\
\text { Willamette Valley...... } \\
\text { Southern Oregon...... } \\
\text { Columbia Basin....... } \\
\text { Blue Mountains........ } \\
\text { Central Oregon........ }\end{array}$ & $\begin{array}{l}127 \\
428 \\
148 \\
204 \\
113 \\
183\end{array}$ & $\begin{array}{r}\$ 1.75 \\
1.50 \\
1.50 \\
1.75 \\
1.75 \\
2.00\end{array}$ & $\begin{array}{r}111 \\
133 \\
23 \\
211 \\
173 \\
130\end{array}$ & $\begin{array}{r}\$ 27.00 \\
29.00 \\
26.00 \\
36.00 \\
36.00 \\
36.00\end{array}$ & $\begin{array}{r}52 \\
180 \\
52 \\
82 \\
47 \\
16\end{array}$ & $\begin{array}{r}\$ 2.25 \\
2.00 \\
2.00 \\
2.00 \\
2.25 \\
2.50\end{array}$ & $\begin{array}{r}21 \\
32 \\
7 \\
14 \\
5 \\
9\end{array}$ & $\begin{array}{l}\$ 55.00 \\
45.00 \\
50.00 \\
48.00 \\
52.00 \\
52.00\end{array}$ \\
\hline State Average..... & & $\$ 1.75$ & & $\$ 35.00$ & & $\$ 2.25$ & & $\$ 49.00$ \\
\hline
\end{tabular}

\section{Miscellaneous Data on Farming Conditions in Oregon. (Table}

2, herewith).

The higher cost of clearing in Western Oregon is due to the heavier growth of trees-chiefly fir or oak. The average cost shown for the Columbia Basin is for the clearing of lands having tree growth. Sage brush covered lands in this division cost no more to clear than elsewhere, about $\$ 5$ per acre. In the Blue Mountain division the clearing consists of sage brush and scattered trees and sometimes floating rock-although the latter is more common in the Central Oregon division. The low cost for Central Oregon is because only sage brush lands have been cleared there as yet to any extent. Scattered juniper tree growth and sage brush together in that division cost about $\$ 15$ per acre to clear.

The smaller number of irrigated acres per farm in Southern Oregon and the Columbia Basin is due to the higher price of irrigated lands and more restricted irrigable areas of those regions, while the large number of irrigated acres per farm in Central Oregon is due to the crude method of irrigation from winter overflow from streams and to the more extensive type of farming done. The per cent using irrigation, shown, is, like all other figures shown in the tables from the Agricultural Survey - only the per cent of representative farms visited and reported upon by the Survey-not the per cent of the total number of farms of the region. Hence, in the Willamette Valley, where almost no irrigation is done and none is necessary, and in the Columbia Basin, where most of the lands are dry farmedthe figures might be misleading.

The percentage of representative farms using rotations and the amount of manure used per farm show the greater development in the use of better farming methods and of dairy cows in the Willamette Valley than elsewhere but still leaves much to be desired, for what the average Oregon farmer calls a rotation is not a definite cropping system for increasing fertility and farm economy and profits per acre, but merely an occasional variation in the crop grown. It is this, together with the fact that much of the crop is fed and sold as livestock, that makes the average crop sales per acre rather low, the chief crops sold direct, being grain. Because of the large amount of dairying this is especially true for the Coast region, while the bare 
summer fallow each alternate year, followed on the Eastern Oregon dry farming lands, accounts for the smaller annual sales per acre in the Columbia Basin and Blue Mountain region.

\section{SOILS OF OREGON.}

\section{Chiel Soil Types in Oregon.}

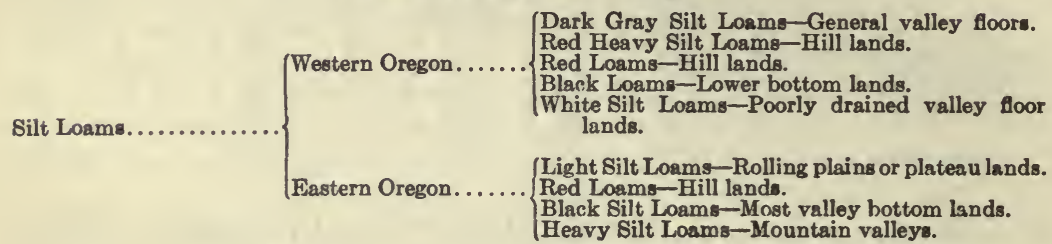

Western Oregon...... \{ $\begin{aligned} & \text { Light Sandy Loams-Coast bluff. } \\ & \text { Gray or Brown Sandy Loams-Rivor flood } \\ & \text { plains. }\end{aligned}$ Sandy Loams.. ..........

(Brown Coarse Sandy Loams-Columbia Bain river bluffs and tributary river bottoms.

Brown or Gray Medium Sandy Loams-Central Oregon rolling plateau land.

Marsh Soils.

(Black "Beaver Dam"-Old marsh soils-Willamette Valley.

Silty; Marsh Muck-Tideland marshes of const and Columbis River.

Raw Peaty Mucks-Tideland marshes and Central Oregon interior marshes.

"Adobe"-Heavy sticky clay soils-black, red, gray-Southern Oregon and in spots throughout the state. Special Types............................. "Granitic Soils"-Coarse sandy oils-yellow,

"Pumice Soils" - Whito or yellow, coarse pumice and sands-Central Oregon towards head of Deschutes River.

"Alkali Soils"-Generally silt loams-local area" in Eastern Oregon only.

\section{Approximate Composition of Some of Chief Oregon Soil Types.}

\begin{tabular}{|c|c|c|c|c|c|c|}
\hline \multirow{2}{*}{ t } & \multirow[b]{2}{*}{ Clay } & \multirow[b]{2}{*}{$\underset{\%}{\text { Silt }}$} & \multicolumn{2}{|c|}{ Sands. } & \multirow[b]{2}{*}{$\begin{array}{c}\text { Total } \\
\text { Rock } \\
\text { Particles } \\
\% \\
\end{array}$} & \multirow[b]{2}{*}{$\begin{array}{c}\text { Organic } \\
\text { Matter } \\
\%\end{array}$} \\
\hline & & & $\begin{array}{c}\text { Very Fine } \\
\text { and } \\
\text { Fine } \%\end{array}$ & $\begin{array}{c}\text { Medium } \\
\text { and } \\
\text { Coarse } \%\end{array}$ & & \\
\hline $\begin{array}{l}\text { silt Loams } \\
\text { Heavy Type (Silt Clay)....... } \\
\text { Average Type............... } \\
\text { Light Type (Loam)......... }\end{array}$ & $\begin{array}{l}31 \\
22 \\
11 \\
\end{array}$ & $\begin{array}{l}62 \\
68 \\
44 \\
\end{array}$ & $\begin{array}{r}5 \\
7 \\
38 \\
\end{array}$ & $\begin{array}{l}2 \\
3 \\
7 \\
\end{array}$ & $\begin{array}{l}100 \\
100 \\
100 \\
\end{array}$ & $\begin{array}{l}8 \\
8 \\
3 \\
\end{array}$ \\
\hline 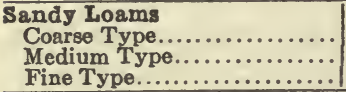 & $\begin{array}{l}2 \\
6 \\
9\end{array}$ & $\begin{array}{r}6 \\
12 \\
21\end{array}$ & $\begin{array}{l}41 \\
60 \\
63\end{array}$ & $\begin{array}{r}51 \\
22 \\
7\end{array}$ & $\begin{array}{l}100 \\
100 \\
100\end{array}$ & $\begin{array}{l}1 \\
3 \\
4\end{array}$ \\
\hline 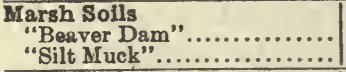 & $\begin{array}{r}8 \\
15 \\
\end{array}$ & $\begin{array}{l}16 \\
43 \\
\end{array}$ & $\begin{array}{l}14 \\
10 \\
\end{array}$ & $\begin{array}{r}11 \\
6\end{array}$ & $\begin{array}{l}49 \\
74 \\
\end{array}$ & $\begin{array}{l}51 \\
28 \\
\end{array}$ \\
\hline $\begin{array}{l}\text { "Adobe" or "Sticky" } \\
\text { (Clay)............................. }\end{array}$ & 53 & 19 & -21 & 7 & 100 & 11 \\
\hline "Granitic".................. & 13 & 17 & 27 & 43 & 100 & 3 \\
\hline
\end{tabular}

The greatest factor in the agricultural wealth of any country is the fertility of its soils. Oregon is widely known for the mildness of temperature, ample rainfall and long growing season prevailing in certain of its districts, yet the state is even more fortunate in 
the possession of a soil cover of unusual natural fertility and great endurance under cropping. Great natural fertility or "strength" of soil is the most valuable agricultural asset a country may possess.

The soils of the state may be roughly divided into four great classes, which in order of importance are as follows:

The Silt Loams. This is the most widespread and most important soil class. The silt loams are found in large areas in practically every county in the state. For total production; for adaption to the widest variety of crops; for natural fertility and for most other desirable farming qualities; this class of soils is the most valuable in Oregon. While the silt loams vary in composition in different parts of the state, their important qualities remain fairly constant. They are universally of high plant food content, particularly in total potassium and phosphorus, yet their greatest claim to productivenes's is their physical character. The average Oregon silt loams are a happy medium between the sandy loam on the one hand and the clay loam on the other, having the bad qualities of neither and the good qualities of both. Often called "volcanic ash" soils, particularly in Eastern Oregon, because of their origin and uniformly fine, powdery texture - they are derived largely from the volcanic basalt, a fine grained dark gray rock high in the mineral plant food elements. The weathered products of this rock, alluvially deposited and mixed with organic matter in greater or less degree, according to the precipitation of the region, form the soil cover of the great valley floors of Western Oregon, the rolling plateau lands of the Columbia Basin, and the inter-mountain valleys of Eastern Oregon.

As their name implies, the chief component of the soils of this class is silt, which is intermediate in texture or size of particles between the clay component on the one hand and the finest grade of sand on the other. Analyses of many samples of Oregon silt loams show their general composition to be, roughly, as shown in table, page 46.

As shown, they are a very uniformly fine grained powdery soil having the desirable qualities of clay for the retention of moisture and plant foods and large surface area for the breaking down of plant foods through chemical and bacterial activities and for feeding plant roots, but because of the relatively small amount of the clay component contained as compared with the amount of silt, these soils drain quickly, warm up and become mellow earlier and handle more easily through a longer working and growing season than the clay loam type. The cold slowness, puddling, clodding, baking, and cracking qualities common to clay soils are absent. On the other hand, they contain little sand and do not dry out during drouth or leach of plant foods as do the sandy loams. Physically this class of soil requires for its maintenance in the highest state of fertility additions of (1) humus forming material through good rotations and (2) ample cultivation. To both extra humus additions and extra tillage, silt loams respond quick and generously. The 
natural fertility of the silt loams is so high that where good rotations are used commercial fertilizers are not required.

In Western Oregon where the rainfall is heavy the silt loams are lacking somewhat in lime and become acid if not amended with applications of the ground - limestone, which material is now available in Oregon and may be used with great profit.

The silt loams of the valley floors or rolling table lands vary in color through all the shades of gray to black, while those of the hill lands range through the shades of red to a deep chocolate or brownish black color.

The silt loams of the valleys of humid Western Oregon or irrigated Eastern Oregon are notable for their high production under intensive handling, especially of forage crops for dairying or diversified farming such as the clovers, alfalfa, vetch, kale, roots, potatoes, corn, grasses, grain, etc., and for high grade fruit production. In the dry farming area of Eastern Oregon these silt loams find great favor because of their remarkable qualities for moisture retention, ease of tillage and availability of plant food.

The Sandy Loams. The sandy loams cover a considerable area in the state, in all cases lying immediately adjacent to present or former water bodies. The low bluff lands immediately on the coast; the flood plains of the rivers throughout the state; old river washes and alluvial fans; the low wind-blown bluffs extending back from the Columbia River; and the great rolling plateau lands of Central Oregon, former bottom of a great inland sea-these are the areas where the sandy loams obtain.

The river flood plains naturally have the richest of these sandy loams-mixed of fine sediments, sands and silts varying from coarse sands at the stream to the finest sandy loams further back. These soils are of good plant food content but under heavy cropping without proper rotation do not have the endurance of the silt loams, as they do not have so great a total plant food supply. Because of their earliness, ease of tillage, quick maturing, and high availability of the plant foods contained, they are adapted to the most intensive methods-trucking, intensive dairying, small fruits, etc. On this account the fertility can be maintained easily enough at the highest state by the use of legumes, manures and fertilizers. For growth of any succulent crop such as roots, kale, cabbage, potatoes, corn, etc., heavy fertilizing will give very profitable and quick returns. This is equally true of the irrigated sandy loams of the Columbia Basin and Central Oregon. Legumes, manure and applications of potassium in commercial form, give splendid results. This type is one of the best in both Western and Eastern Oregon for alfalfa growing.

On the dry farming lands this type is less desirable but still a productive soil as no leaching has occured under the semi-arid conditions and the plant food supply, highly available, has been retained. It must be more carefully farmed than the silt loams 
under these conditions, however, in order to maintain fertility, with good rotations and more or less livestock production, as commercial fertilizers may not be used. (Composition, sandy loams, table, page 46.)

The Marsh Soils. As their name suggests, these soils are the results of the accumulations from the decay of generations of the rank growth of the fresh water marshes, sedges, rushes, "tules", etc.-mixed with more or less silt and other sediments brought in by the adjoining stream. The largest areas of these soils are found along the coast on the rivers below tidewater - such as the Columbia, Coquille and Coos rivers-and surrounding some of the interior lakes east of the Cascades-such as Klamath and Silver Lakes. Smaller former marsh areas are found in the lower Willamette Valley where the beavers, damming up small streams, caused marshesgiving rise to the local name "beaver dam" soils. These "beaver dams", like all marsh soils, are very high in organic matter content, intensely black in color, rich in nitrogen, but deficient in lime and potash, acid in reaction, and nearly always lacking in drainage. Where lying between the stream and higher ground, as practically always they do, these soils vary from (according to the drainage) either deep, black, well decayed organic matter or deep, raw, brown, peaty muck, at the center of the marsh-to a sandy loam at the bank of the stream and a silty muck or clay muck as the higher lands back of the marsh are approached. The rawness of these soils depends altogether on the drainage. While the Western Oregon marsh soils are all acid in reaction, in Eastern and Central Oregon, the reverse is the case, some of the Central Oregon marshes being strongly alkaline.

The first step with marsh soils is reclamation through drainage or, along the coast, through dyking and drainage. These soils are then cleared of their rank growth of marsh grasses, burned, deeply plowed, cropped with oats several years, then to such intensive dairy crops as mangels, turnips, kale, corn, hay and grains, and still later in smaller units to more intensive crops such as potatoes, cabbage, celery, onions, etc., becoming wonderful truck producers. Deficiencies in lime and potash may be very profitably corrected with commercial applications because of the intensive use of these soils. When reclaimed and developed these are among the richest, easiest working and highest priced soils in the state. (Composition, marsh soils, table, page 46.)

The "Adobe" Soils. This type of soil, sometimes called also "black sticky" or "red sticky", according to the color, is found only in limited amounts as compared with the great soil types of the state previously discussed. It occurs in spots, however, in nearly every section of the state, these patches varying in area from a couple of acres to as high as a quarter section in some cases. Many farms in Western Oregon, especially those in portions of the valleys adjacent to the hills, will have a few acres of this type of soil. Probably the largest areas of "sticky" soils are found in the Southern 
Oregon division in the Rogue River Valley and the Umpqua Valley.

As might be inferred, this soil is extreme in nearly all of its qualities. It is very difficult to plow or handle when wet and equally difficult to put in a good state of tilth when dry. It does not drain well and warms up slowly in the spring. On the other hand, it is extremely rich in plant foods, especially in potassium and phosphorous. As shown in the table, page 46, practically all of the extreme qualities of this so-called "adobe", which is really a clay, are due to the extraordinarily high percentage of the clay itself contained, of which component a considerable amount is colloidal or glue-like in character. The most common color of this type is a deep black, but frequently it is red or light gray.

Notwithstanding its objectionable features, this soil is one of the most valuable found in the state when properly handled, and the farmer is well repaid for the additional care it must receive in the splendid returns it gives. Some of the finest quality and heaviest yields of such fruits as pears and apples and of vegetables of many kinds, of field corn, and other cultivated crops, are obtained from this peculiarly rich land. The handling qualities of this soil, which rolls off of the moldboard like putty when too moist and becomes as hard as iron, baking and cracking like joint clay, when too dry, may be greatly improved by heavy additions of barnyard manure and green manures to increase the humus content, together with heavy applications of ground limestone. As this type frequently occurs at the base of hills where there is considerable seepage, very commonly under-drainage with tile is required to permit of its redemption in the way suggested. Care in plowing at just the right time, when it is not too wet to puddle or smear, and to complete the plowing quickly before it gets so dry as to become cloddy, is an important essential. Good rotations devoted largely to thoroughly cultivated crops should be followed.

The "Granitic" Soils. This type of soil occurs only in Southern Oregon, largely in the Rogue River Valley, where considerable areas of it are found on portions of the rolling hill lands and in the valleys. While much of the soil of the Rogue River Valley is derived from the granite rock, the soils commonly designated by the term "granitic" and referred to here, are the very coarse sandy areas, nearly white, light gray, yellow, or light red in color, which are as yet but little used for agriculture. As indicated, these "granitic" soils are very coarse in texture, having large amounts of coarse sands and only relatively small amounts of silt and clay. As might be expected, this soil is lacking in natural strength, being low in nitrogen and organic matter and potassium and phosphorus. The plant food contained, however, is in a fairly available form and with proper handling these areas will undoubtedly become valuable. The sandiness of the soil makes it early and desirable for rapid growing crops such as vegetables, peaches, strawberries, and the like, where early maturity is desired. Further, the soil responds wonderfully to the application of fertilizers and the use of good 
rotations. Barnyard and green "manures together with the growing of leguminous crops such as will add large amounts of humus, give splendid results. With this sort of treatment and the addition of reasonable amounts of commercial fertilizers, the fertility of this soil will be greatly increased and its producing strength may be permanently maintained for profitable cropping. Some of these lands already farmed, have grown products of splendid quality. (Composition, Table, Page 46.)

The "Pumice" Soils. This peculiar type covers only a limited area at the head of the Deschutes River in Central Oregon. It is white, gray, yellow, or light brown in color and very coarse and porous in texture, being made up largely of partially disintegrated pumice. Pumice is a very soft, exceedingly light and fine grained porous rock of volcanic origin, which might be most aptly described as volcanic spume. The qualities and agricultural value of this "pumice" soil are as yet largely undetermined. The plant food content appears to be reasonably good, but the peculiar physical character (lightness in weight, and great porosity), combined with the rather high altitudes at which it is found, make the best use and production possibilities of this soil, problematic, and its ultimate use and value are yet to be determined. Because of its peculiar physical qualities, its mechanical composition is not given here.

The "Alkali" Soils. Because of the heavy rainfall, alkali soils do not occur west of the Cascades in Oregon. In Eastern Oregon practically all of the soils are moderately alkaline in reaction, but only sufficiently so to make this quality of great value in offering desirable soil conditions for crop production. Only in those areas of the semi-arid districts where the land lies so flat or pan-like as to lack good natural drainage does the alkali become so excessive in amount as to be injurious to crop production. The presence of injurious amounts of alkali is indicated in dry weather by the appearance on the surface soil of the whitish powder or crystals of the "white" alkalies, or the blackish brown stains of the "black" alkali; but at any time of the year the absence of the heavy black sage and the presence of such alkali-resistant plants as greasewood, saltbush, saltgrass, etc., together with the observable lack of natural drainage, are good indications of the presence of excessive amounts of salts. Such areas are to be avoided, unless the land can be artifificially drained and irrigated. On irrigable lands, artificial drainage followed by flooding with irrigation water will wash out excessive alkali, and the use of heavy dressings of barnyard manure and green manures together with deep plowing and thorough summer cultivation to stop surface evaporation of moisture, will reduce and distribute the alkali so that profitable production may become possible.

On dry farming lands strong alkali areas are very undesirable. While deep plowing and the addition of organic matter, greatly improve such areas and in many cases entirely reclaim them, yet for the most part strongly alkaline spots in the soil are to be avoided for this type of farming. In portions of Central Oregon, alkali 
hardpans are not uncommon in the subsoil. Such lands should always be examined by making borings to determine the presence of this undesirable condition. It has been found in many cases in the Central Oregon dry farming lands, where such hardpans occur that the conservation of moisture resultant from the use of good dry farming methods tends to dissolve and melt down these hard pans so that they are no longer injurious to crop growth, but where possible it is better to avoid this condition.

\section{FARM CROPS OF OREGON}

\section{Oregon and Other States.}

That the opportunity for the grower of field crops in Oregon is unusual there are authoritative records to prove. A comparison of Oregon crops with those of other well known states which lead in the total production of the chief field crops shows almost without exception that with the rate at which Oregon soils produce-in yield per acre and also very commonly, in price per bushel or value of the goods produced - this state is superior to the largest producers in the Union. This remains true whether the average yield per acre for the past ten years be taken or the yield of the last crop year.

(See Tables 3 and 4, pages 53 and 54.)

\section{Oregon Crop Production by Regions.}

The counties in the state in which the largest amounts of each crop is produced is shown on page 55. Comparison of the total production of the most important crops in the different districts of the state is shown on page 54. It will be noted that the Willamette Valley leads in the production of Oats, Potatoes, Hops, Corn, Clover Hay and Seed, Vetch Hay and Seed, Timothy and Clover, Grain cut green, Kale, and total Hay of all kinds. The Columbia Basin leads in Wheat and Barley. Central Oregon is first in Alfalfa and in Grass Hay, and the Blue Mountain region is a close second in Alfalfa, Clover and Timothy, and in Grass Hay.

The average size of the acreage on the individual farm, the average yield per acre, and the average price and value for each important crop in each different district is shown in the data obtained in the Agricultural Survey of representative farms of the state. (See pages 56 to 59). In studying these tables it should be remembered how the various sections differ as to rainfall, irrigation, price of land, etc., in making comparison of yields. The crop yields named are average yields in all cases; taken from farms that were selected as representing average possibilities in each region. Further, the year 1911 in most parts of Oregon was below normal both for yields and prices. The averages, yields and prices are all the actual figures obtained on these farms for 1911. It should be observed that the figures under AVERAGE VALUE PER ACRE are not obtained by multiplying AVERAGE YIELD by AVERAGE PRICE but are the average of values actually obtained and may include the value of straw, 
etc. The yields where the best methods are used and in more favorable seasons are much higher, in most cases, than those given in the tables.

\section{OREGON YIELDS AND PRICES COMPARED WITH STATES LEADING IN TOTAL PRODUCTION.}

(Note: In each table the first three states named lead in total production in the order named. Figures taken from last U. S. Census.)

Table 1

WHEAT

\begin{tabular}{|c|c|c|}
\hline Largest Producers. & $\begin{array}{c}\text { Yield in Bushels. } \\
\text { Average } 10 \text { Years. } \\
1900-1909 .\end{array}$ & $\begin{array}{c}\text { Yield in Bushels. } \\
\text { Average } \\
1912 .\end{array}$ \\
\hline
\end{tabular}

Table 2

BARLEY.

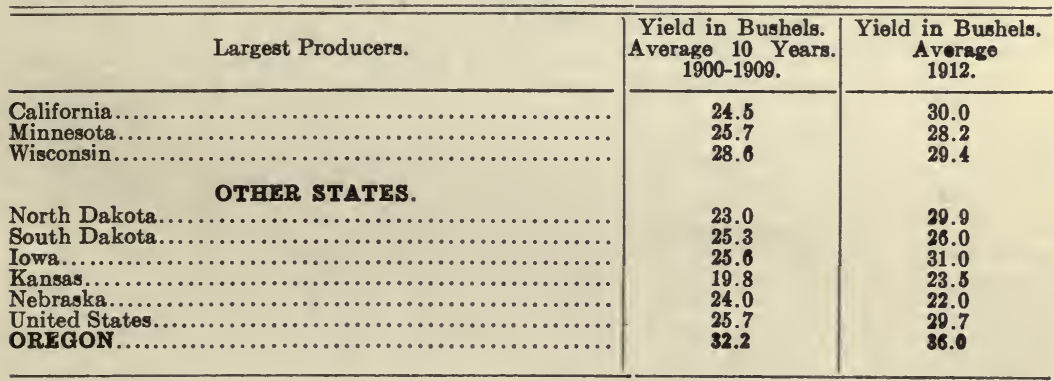

\begin{tabular}{|c|c}
\hline $\begin{array}{c}\text { Yield in Bushels. } \\
\text { Average } 10 \text { Years. } \\
1800-1009 .\end{array}$ & $\begin{array}{c}\text { Yield in Bushels. } \\
\text { Average } \\
1012 .\end{array}$ \\
\hline 92.0 & 120.0 \\
88.0 & 105.0 \\
88.0 & 107.0 \\
& \\
88.0 & 135.0 \\
79.0 & 114.0 \\
76.0 & 82.0 \\
84.0 & 112.0 \\
85.0 & 101.0 \\
91.4 & 11.0 \\
109.0 & 15.50 \\
\hline
\end{tabular}




\begin{tabular}{|c|c|c|}
\hline Largest Producers. & $\begin{array}{l}\text { Yield in Tons. } \\
\text { Average } 10 \text { Years. } \\
\text { 1900-1909. }\end{array}$ & $\begin{array}{l}\text { Yield in Tons. } \\
\text { Average } \\
\text { 1912. }\end{array}$ \\
\hline 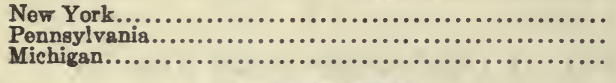 & $\begin{array}{l}1.22 \\
1.32 \\
1.34\end{array}$ & $\begin{array}{l}1.25 \\
1.43 \\
1.33\end{array}$ \\
\hline 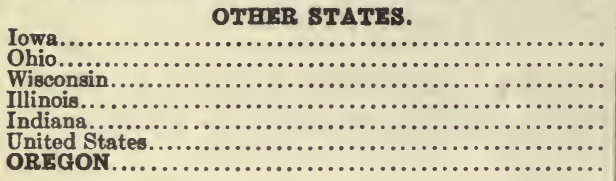 & $\begin{array}{l}1.55 \\
1.38 \\
1.56 \\
1.35 \\
1.36 \\
1.44 \\
2.11\end{array}$ & $\begin{array}{l}1.40 \\
1.86 \\
1.60 \\
1.30 \\
1.37 \\
1.47 \\
2.20\end{array}$ \\
\hline
\end{tabular}

FIELD PEAS.

\begin{tabular}{|c|c|c|}
\hline Largest Producers. & Yield in Bushels. & $\begin{array}{c}\text { Value Per } \\
\text { Bushel } \\
1909 .\end{array}$ \\
\hline 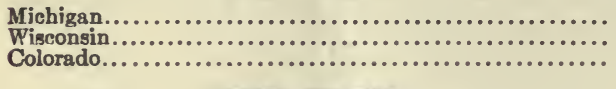 & $\begin{array}{l}12.24 \\
16.2 \\
10.65\end{array}$ & $\begin{array}{l}1.15 \\
1.41 \\
1.53\end{array}$ \\
\hline 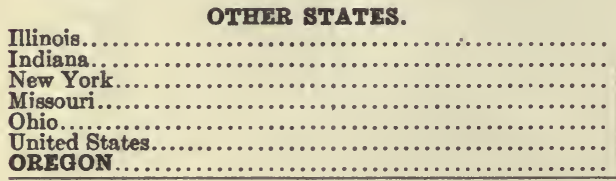 & $\begin{array}{r}4.5 \\
6.74 \\
17.84 \\
4.74 \\
9.41 \\
5.46 \\
21.4\end{array}$ & $\begin{array}{l}1.48 \\
1.51 \\
1.64 \\
1.64 \\
1.74 \\
1.50 \\
1.71\end{array}$ \\
\hline
\end{tabular}

OATS.

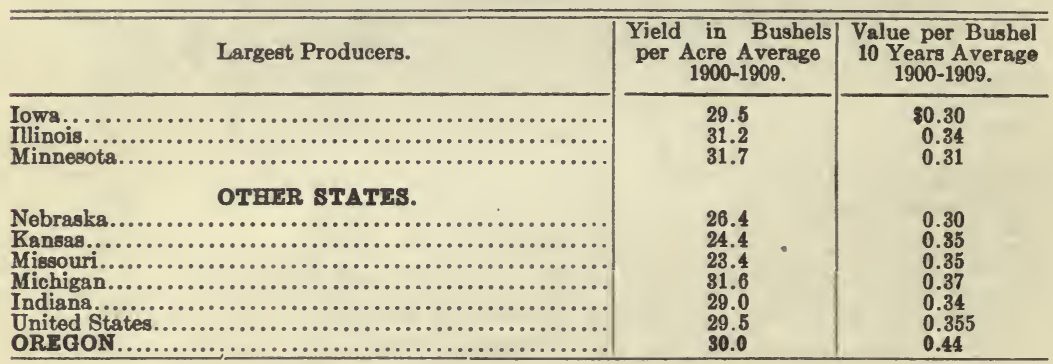

OREGON LEADS IN HOP PRODUCTION. (From U. S. Census).

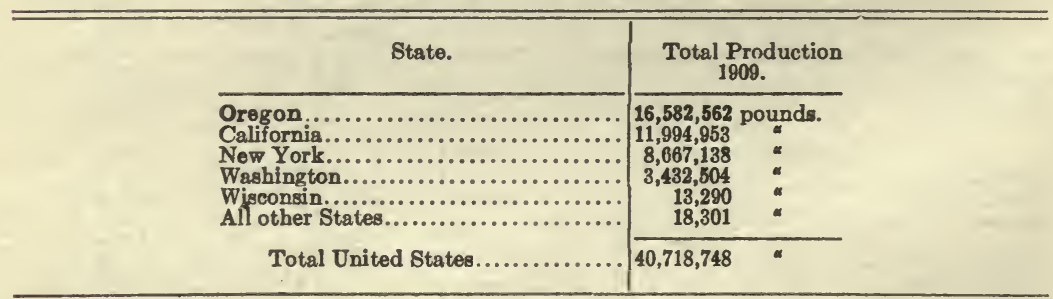




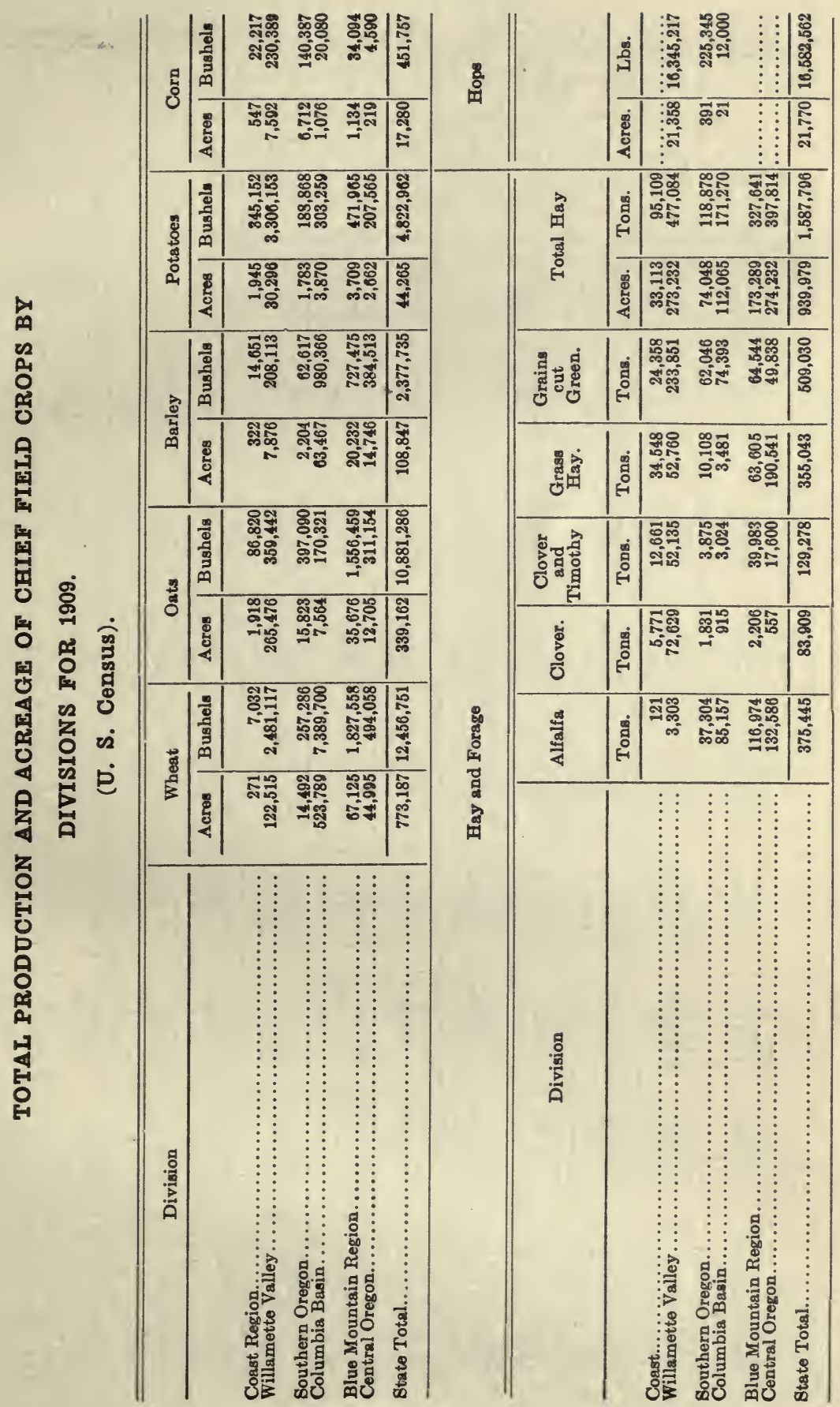




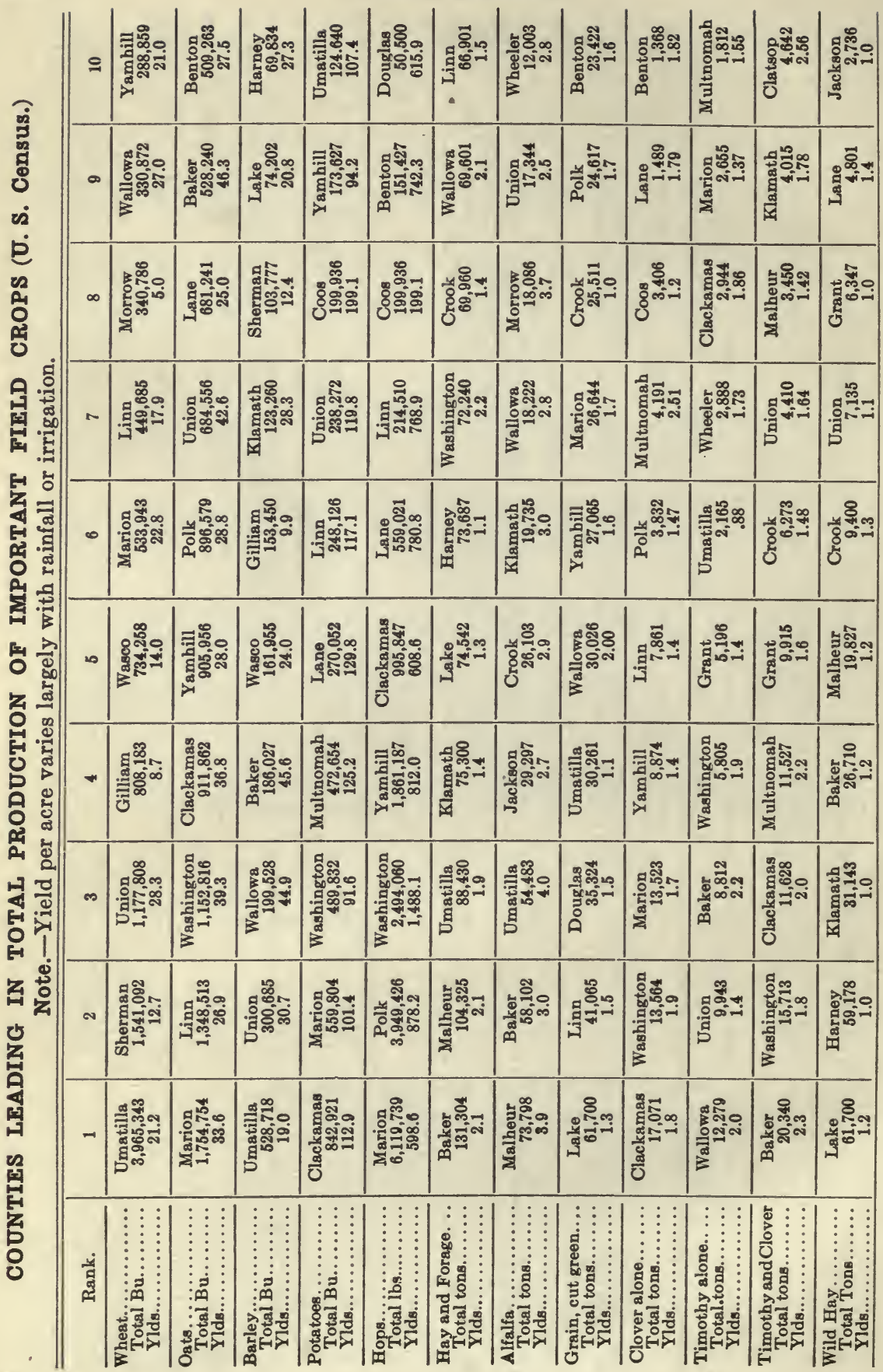


AVERAGE FARM ACREAGE, PRICE, YIELD AND VALUE OF EACH OF THE CHIEF FIELD CROPS IN THE DIFFERENT REGIONS OF

\section{OREGON-AS GROWN ON REPRESENTATIVE FARMS}

IN 1911.

\section{From Agricultural Surreg.}

Note: In all these tables the size of the farm acreage indicates to a considerable extent the relative importance of the crop in the different regions.

WINTER WHEAT.

\begin{tabular}{|c|c|c|c|c|c|c|c|c|}
\hline Division. & $\begin{array}{l}\text { No. } \\
\text { Reports. }\end{array}$ & $\begin{array}{c}\text { Ave. } \\
\text { Acreage. }\end{array}$ & $\begin{array}{c}\text { No. } \\
\text { Reports. }\end{array}$ & $\begin{array}{l}\text { Ave. } \\
\text { Price. }\end{array}$ & $\begin{array}{c}\text { No. } \\
\text { Reports. }\end{array}$ & $\begin{array}{l}\text { Ave. } \\
\text { Yield. }\end{array}$ & $\begin{array}{c}\text { No. } \\
\text { Reports. }\end{array}$ & $\begin{array}{l}\text { Ave } \\
\text { Value per } \\
\text { Acre. }\end{array}$ \\
\hline $\begin{array}{l}\text { Coast...... Vialiey } \\
\text { Willamette Valog } \\
\text { Southern Oregon. } \\
\text { Columbia Basin.. } \\
\text { Blue Mountain... } \\
\text { Central Oregon... }\end{array}$ & $\begin{array}{r}4 \\
247 \\
20 \\
103 \\
40 \\
22\end{array}$ & $\begin{array}{r}4 \\
26 \\
20 \\
377 \\
373 \\
63\end{array}$ & $\begin{array}{r}2 \\
167 \\
13 \\
87 \\
24 \\
16\end{array}$ & $\begin{array}{r}81.00 \\
.84 \\
1.17 \\
.73 \\
.75 \\
.97\end{array}$ & $\begin{array}{r}3 \\
236 \\
18 \\
98 \\
30 \\
17\end{array}$ & $\begin{array}{l}31 \\
26 \\
22 \\
29 \\
27 \\
21\end{array}$ & $\begin{array}{r}2 \\
104 \\
9 \\
53 \\
2 \\
13\end{array}$ & $\begin{array}{l}\$ 28.00 \\
21.00 \\
23.00 \\
12.00 \\
27.00 \\
25.00\end{array}$ \\
\hline State Average.... & ........... & 96 & $\ldots \ldots, \ldots$ & $\$ 0.86$ & & 26 & ……… & $\$ 20.00$. \\
\hline
\end{tabular}

The winter wheat, the leading grain crop of the state, is grown largely (See above table) in the Columbia Basin and Central Oregon and Blue Mountain regions under the dry farming systems, as shown by the size of the average individual farm acreage. The best common varieties are the Turkey Red, Forty-Fold, on the lighter soils and dryer areas, and Red Chaff and Dale's Gloria, on the heavier and moister areas. The range in dry farming yields in the different parts of these regions is from 10 bushels to 50 bushels per acre, with the land "summer fallowed" alternate years. The seeding rate is $\mathbf{4 5}$ pounds to the acre, except in Central Oregon, where 20 pounds is the prevailing rate. Wheat growing in Western Oregon is on the decline, giving place to barley and oats and more intensive crops.

SPRING WHEAT.

\begin{tabular}{|c|c|c|c|c|c|c|c|c|}
\hline Division. & $\begin{array}{c}\text { No. } \\
\text { Reports. }\end{array}$ & $\begin{array}{l}\text { Ave. } \\
\text { Acreage. }\end{array}$ & $\begin{array}{c}\text { No. } \\
\text { Reports. }\end{array}$ & $\begin{array}{l}\text { Ave. } \\
\text { Price. }\end{array}$ & $\begin{array}{c}\text { No. } \\
\text { Reports. }\end{array}$ & $\begin{array}{l}\text { Ave. } \\
\text { Yield. }\end{array}$ & $\begin{array}{c}\text { No. } \\
\text { Reports. }\end{array}$ & $\begin{array}{c}\text { Ave } \\
\text { Value per } \\
\text { Acre. }\end{array}$ \\
\hline $\begin{array}{l}\text { Coast.... Taliey } \\
\text { Willamette Valiey } \\
\text { Southern Oregon. } \\
\text { Columbia Basin.. } \\
\text { Blue Mountain... } \\
\text { Central Oregon.. }\end{array}$ & $\begin{array}{r}12 \\
126 \\
7 \\
35 \\
94 \\
51\end{array}$ & $\begin{array}{r}4 \\
15 \\
23 \\
128 \\
41 \\
48\end{array}$ & $\begin{array}{r}3 \\
93 \\
5 \\
20 \\
99 \\
43\end{array}$ & $\begin{array}{r}\$ 1.00 \\
.77 \\
1.08 \\
.72 \\
.85 \\
.95\end{array}$ & $\begin{array}{r}5 \\
122 \\
6 \\
23 \\
32 \\
47\end{array}$ & $\begin{array}{l}31 \\
26 \\
23 \\
21 \\
26 \\
29\end{array}$ & $\begin{array}{r}3 \\
68 \\
1 \\
14 \\
6 \\
32\end{array}$ & $\begin{array}{l}\$ 32.00 \\
20.00 \\
36.00 \\
20.00 \\
33.00 \\
25.00\end{array}$ \\
\hline State Average.. & . & 39 & 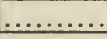 & 580.86 & & 27 & ....... & $\$ 23.00$ \\
\hline
\end{tabular}

Spring wheat is also grown largely in Eastern Oregon, but in not nearly so large acreages as winter wheat. It is sown on such land as cannot be seeded in the fall. It is giving way to other spring-sown crops such as emmer, field peas, etc. Blue-stem is the best common variety. 
OATS.

\begin{tabular}{|c|c|c|c|c|c|c|c|c|}
\hline Division. & $\begin{array}{c}\text { No. } \\
\text { Reports. }\end{array}$ & $\begin{array}{c}\text { Ave. } \\
\text { Acreage. }\end{array}$ & $\begin{array}{c}\text { No. } \\
\text { Reports. }\end{array}$ & $\begin{array}{l}\text { Ave. } \\
\text { Price. }\end{array}$ & $\begin{array}{c}\text { No. } \\
\text { Reports. }\end{array}$ & $\begin{array}{l}\text { Ave. } \\
\text { Yield. }\end{array}$ & $\begin{array}{c}\text { No. } \\
\text { Reports. }\end{array}$ & $\begin{array}{l}\text { Ave } \\
\text { Value per } \\
\text { Acre. }\end{array}$ \\
\hline $\begin{array}{l}\text { Coast.... Wï Vailey } \\
\text { Willamette } \\
\text { Southern Oregon. } \\
\text { Columbia Basin.. } \\
\text { Blue Mountain... } \\
\text { Central Oregon... }\end{array}$ & $\begin{array}{r}22 \\
340 \\
63 \\
44 \\
61 \\
28\end{array}$ & $\begin{array}{l}11 \\
37 \\
16 \\
45 \\
35 \\
29\end{array}$ & $\begin{array}{r}17 \\
214 \\
28 \\
14 \\
37 \\
19\end{array}$ & $\begin{array}{r}50.36 \\
.41 \\
.57 \\
.54 \\
.55 \\
.66\end{array}$ & $\begin{array}{r}21 \\
278 \\
62 \\
28 \\
50 \\
26\end{array}$ & $\begin{array}{l}46 \\
40 \\
37 \\
42 \\
53 \\
33\end{array}$ & $\begin{array}{r}14 \\
107 \\
8 \\
6 \\
16 \\
9\end{array}$ & $\begin{array}{l}\$ 24.00 \\
17.00 \\
18.00 \\
13.00 \\
30.00 \\
18.00\end{array}$ \\
\hline State Average.... & . & 31 & $\ldots$ & $\$ 0.51$ & 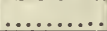 & 42 & $\ldots$ & 18.00 \\
\hline
\end{tabular}

The production of oats is increasing in amount and yield as better rotations and varieties are used, the bulk of the crop being grown in the Willamette Valley and considerable amounts in irrigated sections of Eastern Oregon. (See above table). Oat prices are always very good. The best common varieties are Swedish Select, Silvermine, Improved American, Shadeland Climax, and on the dry lands, Sixty-Day.

BARIEY.

\begin{tabular}{|c|c|c|c|c|c|c|c|c|}
\hline Division. & $\begin{array}{l}\text { No. } \\
\text { Reports. }\end{array}$ & $\begin{array}{l}\text { Ave. } \\
\text { Acreage. }\end{array}$ & $\begin{array}{c}\text { No. } \\
\text { Reports. }\end{array}$ & $\begin{array}{l}\text { Ave. } \\
\text { Price. }\end{array}$ & $\begin{array}{c}\text { No. } \\
\text { Reports. }\end{array}$ & $\begin{array}{l}\text { Ave. } \\
\text { Yield. }\end{array}$ & $\begin{array}{c}\text { No. } \\
\text { Reports. }\end{array}$ & $\begin{array}{l}\text { Ave } \\
\text { Value per } \\
\text { Acre. }\end{array}$ \\
\hline $\begin{array}{l}\text { Coast..... } \\
\text { Willametio Viliey } \\
\text { Southern Oregon. } \\
\text { Columbia Basin.. } \\
\text { Blue Mountain... } \\
\text { Central Oregon... }\end{array}$ & $\begin{array}{l}11 \\
50 \\
20 \\
45 \\
45 \\
55\end{array}$ & $\begin{array}{r}3 \\
12 \\
7 \\
73 \\
35 \\
37\end{array}$ & $\begin{array}{r}2 \\
22 \\
4 \\
17 \\
32 \\
44\end{array}$ & $\begin{array}{r}\$ 0.78 \\
.76 \\
.76 \\
.65 \\
.90 \\
.84\end{array}$ & $\begin{array}{l}1 \\
48 \\
17 \\
28 \\
39 \\
50\end{array}$ & $\begin{array}{l}50 \\
40 \\
37 \\
33 \\
39 \\
31\end{array}$ & $\begin{array}{r}1 \\
18 \\
3 \\
7 \\
9 \\
96\end{array}$ & $\begin{array}{l}\$ 25.00 \\
36.00 \\
24.00 \\
20.00 \\
27.00 \\
28.00\end{array}$ \\
\hline State A verage.. & 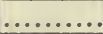 & 28 & …...... & $\$ 0.78$ & 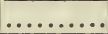 & 46 & ........ & 27.00 \\
\hline
\end{tabular}

Nearly all the barley is grown in Eastern Oregon on both dry farming and irrigated lands. (See above table). The demand for both brewing and feed barley is excellent. Much improved varieties are being introduced of late. The crop gives very large yields in Western Oregon where good rotations are used. The best varieties are the Swan Neck and Hannchen for dry farms and the Wisconsin Pedigreed elsewhere.

POTATOES

\begin{tabular}{|c|c|c|c|c|c|c|c|c|}
\hline Division. & $\begin{array}{c}\text { No. } \\
\text { Reports. }\end{array}$ & $\begin{array}{c}\text { Ave. } \\
\text { Acreage. }\end{array}$ & $\begin{array}{c}\text { No. } \\
\text { Reports. }\end{array}$ & $\begin{array}{l}\text { Ave. } \\
\text { Price. }\end{array}$ & $\begin{array}{c}\text { No. } \\
\text { Reports. }\end{array}$ & $\begin{array}{l}\text { Ave. } \\
\text { Yield. }\end{array}$ & $\begin{array}{c}\text { No. } \\
\text { Reports. }\end{array}$ & $\begin{array}{l}\text { Ave } \\
\text { Value per } \\
\text { Acre. }\end{array}$ \\
\hline $\begin{array}{l}\text { Cosast.............. } \\
\text { Willametio Valiey } \\
\text { Southern Oregon. } \\
\text { Columbia Basin.. } \\
\text { Blue Mountain... } \\
\text { Central Oregon... }\end{array}$ & $\begin{array}{r}100 \\
370 \\
77 \\
58 \\
29 \\
81\end{array}$ & $\begin{array}{l}2 \\
3 \\
2 \\
3 \\
4 \\
3\end{array}$ & $\begin{array}{r}48 \\
276 \\
26 \\
8 \\
24 \\
68\end{array}$ & $\begin{array}{r}\$ 0.86 \\
.85 \\
.97 \\
1.03 \\
1.11 \\
.82 \\
\end{array}$ & $\begin{array}{r}70 \\
208 \\
13 \\
31 \\
15 \\
66\end{array}$ & $\begin{array}{l}194 \\
156 \\
262 \\
146 \\
127 \\
196\end{array}$ & $\begin{array}{r}19 \\
123 \\
2 \\
10 \\
7 \\
42\end{array}$ & $\begin{array}{l}\$ 116.00 \\
152.05 \\
287.00 \\
203.00 \\
104.00 \\
141.00\end{array}$ \\
\hline State A verage.... & …..... & 3 & $\ldots \ldots$ & $\$ 0.92$ & ........ & 175 & .. & $\$ 148.00$ \\
\hline
\end{tabular}

The Willamette Valley produces the bulk of the potato crop on its sandy river loams or rich red hill lands. (See above table). There is a considerable amount produced in the irrigated sections of Eastern Oregon. Probably the potatoes of the finest quality and 
flavor are grown on the dry farming lands. The market is nearly always good, 1912 being an "off" year for Oregon as well as the rest of the United States. Yields are very high where good methods are used. The best common varieties are the American Wonder and the Burbank.

ALFALFA.

\begin{tabular}{|c|c|c|c|c|c|c|c|c|}
\hline Division. & $\begin{array}{c}\text { No. } \\
\text { Reports. }\end{array}$ & $\begin{array}{c}\text { Ave. } \\
\text { Acreage. }\end{array}$ & $\begin{array}{c}\text { No. } \\
\text { Reports. }\end{array}$ & $\begin{array}{l}\text { Ave. } \\
\text { Price. }\end{array}$ & $\begin{array}{c}\text { No. } \\
\text { Reports. }\end{array}$ & $\begin{array}{l}\text { Ave. } \\
\text { Yield. }\end{array}$ & $\begin{array}{c}\text { No. } \\
\text { Reports. }\end{array}$ & $\begin{array}{c}\text { Ave } \\
\text { Value per } \\
\text { Acre. }\end{array}$ \\
\hline $\begin{array}{l}\text { Coast...... } \\
\text { Willamotio Viliey } \\
\text { Southern Oregon. } \\
\text { Colung bia Basin.. } \\
\text { Blue Mountain... } \\
\text { Central Oregon... }\end{array}$ & $\begin{array}{l}357 \\
148 \\
204 \\
112 \\
183\end{array}$ & $\begin{array}{l}\text { 1i } \\
17 \\
33 \\
59 \\
59\end{array}$ & $\begin{array}{r}31 \\
116 \\
87 \\
105 \\
98\end{array}$ & $\begin{array}{r}\$ 9.00 \\
13.50 \\
9.50 \\
7.50 \\
8.00\end{array}$ & $\begin{array}{l}713 \\
50 \\
65 \\
64 \\
73\end{array}$ & $\begin{array}{l}\dddot{3} .10 \\
3.8 \\
4.0 \\
2.8 \\
2.5\end{array}$ & $\begin{array}{r}93 \\
110 \\
81 \\
90 \\
82\end{array}$ & $\begin{array}{l}\$ 33.00 \\
50.00 \\
44.00 \\
24.00 \\
26.00\end{array}$ \\
\hline tate Average.... & & 35 & 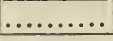 & $\$ 9.50$ & ..... & 3.5 & …...... & $\$ 35.00$ \\
\hline
\end{tabular}

Alfalfa is grown practically altogether in Eastern Oregon on irrigated lands. (See above table). On the Coast a few experimental acres are grown and in the Willamette Valley a number of small plantings are doing well under intensive management as a soiling (green feeding) crop for the dairy cows during the summer months. In Southern Oregon the crop does well under irrigation without special treatment. Northeast Malheur County on the Snake River is the heaviest yielding alfalfa section in the state. Alfalfa has been grown very successfully on the dry farms in rows for seed, and this use of the crop is spreading as such seed is of the highest quality.

CLOVER.

\begin{tabular}{|c|c|c|c|c|c|c|c|c|}
\hline Division. & $\begin{array}{c}\text { No. } \\
\text { Reports. }\end{array}$ & $\begin{array}{c}\text { Ave. } \\
\text { Acreage. }\end{array}$ & $\begin{array}{c}\text { No. } \\
\text { Reports. }\end{array}$ & $\begin{array}{l}\text { Ave. } \\
\text { Price. }\end{array}$ & $\begin{array}{c}\text { No. } \\
\text { Reports. }\end{array}$ & $\begin{array}{c}\text { Ave. } \\
\text { Yield. }\end{array}$ & $\begin{array}{c}\text { No. } \\
\text { Reports. }\end{array}$ & $\begin{array}{c}\text { Ave } \\
\text { Value per } \\
\text { Acre. }\end{array}$ \\
\hline $\begin{array}{l}\text { Coast............. } \\
\text { Willamette Valley } \\
\text { Southern Oregon. } \\
\text { Columbia Basin.. } \\
\text { Blue Mountain... } \\
\text { Contral Oregon... }\end{array}$ & $\begin{array}{l}13 \\
24 \\
50 \\
34 \\
68\end{array}$ & $\begin{array}{r}16 \\
17 \\
5 \\
26 \\
42 \\
61\end{array}$ & $\begin{array}{r}130 \\
190 \\
19 \\
5 \\
6 \\
24\end{array}$ & $\begin{array}{r}\$ 9.50 \\
9.00 \\
12.00 \\
17.00 \\
9.00 \\
12.50\end{array}$ & $\begin{array}{r}25 \\
87 \\
5 \\
2 \\
4 \\
13\end{array}$ & $\begin{array}{l}2.90 \\
2.50 \\
2.80 \\
3.30 \\
2.40 \\
1.90\end{array}$ & $\begin{array}{r}109 \\
174 \\
18 \\
5 \\
5 \\
20\end{array}$ & $\begin{array}{l}\$ 34.00 \\
18.00 \\
27.00 \\
54.00 \\
15.00 \\
18.00\end{array}$ \\
\hline State Average... & $\ldots \ldots \ldots$ & 22 & $\ldots \ldots \ldots \ldots$ & $\$ 10.50$ & .......... & 2.60 & $\ldots \ldots \ldots \ldots$ & $\$ 22.00$ \\
\hline
\end{tabular}

Clover is the great Willamette Valley hay and seed crop. (See above table). Much is grown on the Central Oregon irrigated lands. High yielding both as hay and seed crop and very valuable as hay, pasture, soiling, seed and fertility-restoring crop, no country anywhere, excells Oregon in clover growing and few equal her. Four tons per acre is not an uncommon yield. The common or medium red clover is the chief variety, although a great deal of alsike is grown on the wetter lands. These two are grown both for seed and hay and soiling purposes - the seed crops being especially profitable. Yields of six or seven bushels of red clover seed per acre are frequent. White clover is in the pastures everywhere and crimson clover is grown as a winter cover and green manuring crop. 
TIMOTHY.

\begin{tabular}{|c|c|c|c|c|c|c|c|c|}
\hline Division. & $\begin{array}{c}\text { No. } \\
\text { Reports. }\end{array}$ & $\begin{array}{c}\text { Ave. } \\
\text { Acreage. }\end{array}$ & $\begin{array}{l}\text { No. } \\
\text { Reports. }\end{array}$ & $\begin{array}{l}\text { Ave. } \\
\text { Price. }\end{array}$ & $\begin{array}{c}\text { No. } \\
\text { Reports. }\end{array}$ & $\begin{array}{l}\text { Ave. } \\
\text { Yield. }\end{array}$ & $\begin{array}{l}\text { No. } \\
\text { Roports. }\end{array}$ & $\begin{array}{l}\text { Ave. } \\
\text { Value per } \\
\text { Acre. }\end{array}$ \\
\hline $\begin{array}{l}\text { Coast.............. } \\
\text { Willamette Valley } \\
\text { Southern Oregon. } \\
\text { Columbia Basin.. } \\
\text { Blue Mountain... } \\
\text { Central Oregon... }\end{array}$ & $\begin{array}{r}8 \\
53 \\
9 \\
11 \\
26 \\
13\end{array}$ & $\begin{array}{l}15 \\
19 \\
14 \\
48 \\
67 \\
72\end{array}$ & $\begin{array}{r}2 \\
25 \\
4 \\
4 \\
20 \\
11\end{array}$ & $\begin{array}{r}\$ 10.00 \\
13.13 \\
13.75 \\
12.67 \\
9.87 \\
9.68\end{array}$ & $\begin{array}{r}6 \\
48 \\
9 \\
7 \\
25 \\
13\end{array}$ & $\begin{array}{l}2.8 \\
2.8 \\
1.9 \\
2.6 \\
2.1 \\
1.8\end{array}$ & $\begin{array}{r}2 \\
11 \\
3 \\
1 \\
12 \\
12\end{array}$ & $\begin{array}{r}\$ 25.00 \\
20.00 \\
31.00 \\
15.00 \\
18.00 \\
20.00\end{array}$ \\
\hline State Average.... & & 38 & & $\$ 11.67$ & & 2.2 & & $\$ 21.00$ \\
\hline
\end{tabular}

The Blue Mountain region under irrigation produces the largest amounts and finest quality of timothy alone and considerable amounts of timothy and clover mixed. The Willamette Valley leads in the production of the latter, however. This is another hay crop which yields exceptionally well, especially under irrigation. Timothy seed is also a profitable Oregon crop.

GRAIN HAY.

\begin{tabular}{|c|c|c|c|c|c|c|c|c|}
\hline Division. & $\begin{array}{c}\text { No. } \\
\text { Reports. }\end{array}$ & $\begin{array}{c}\text { Ave. } \\
\text { Acreage. }\end{array}$ & $\begin{array}{c}\text { No. } \\
\text { Roports. }\end{array}$ & $\begin{array}{c}\text { Ave. } \\
\text { Price. }\end{array}$ & $\begin{array}{l}\text { No. } \\
\text { Roports. }\end{array}$ & $\begin{array}{l}\text { Ave. } \\
\text { Yield. }\end{array}$ & $\begin{array}{c}\text { No. } \\
\text { Reports. }\end{array}$ & $\begin{array}{l}\text { Ave. } \\
\text { Value per } \\
\text { Acre. }\end{array}$ \\
\hline $\begin{array}{l}\text { Coast.............. } \\
\text { Willamette Valley } \\
\text { Southern Oregon. } \\
\text { Columbia Basin.. } \\
\text { Blue Mountain... } \\
\text { Central Oregon... }\end{array}$ & $\begin{array}{r}81 \\
95 \\
80 \\
120 \\
38 \\
113\end{array}$ & $\begin{array}{r}12 \\
12 \\
7 \\
48 \\
29 \\
43\end{array}$ & $\begin{array}{l}25 \\
46 \\
34 \\
38 \\
10 \\
79\end{array}$ & $\begin{array}{r}\$ 10.96 \\
10.20 \\
13.73 \\
11.25 \\
8.62 \\
10.57\end{array}$ & $\begin{array}{r}75 \\
91 \\
78 \\
75 \\
29 \\
102\end{array}$ & $\begin{array}{l}4.0 \\
1.8 \\
1.9 \\
1.6 \\
2.3 \\
1.3\end{array}$ & $\begin{array}{r}29 \\
40 \\
17 \\
33 \\
6 \\
87\end{array}$ & $\begin{array}{r}\$ 50.00 \\
17.00 \\
28.00 \\
17.00 \\
17.00 \\
15.00\end{array}$ \\
\hline State A verage.... & ..... & 25 & $\ldots \ldots \ldots$ & $\$ 10.71$ & & 2.0 & ....... & $\$ 22.00$ \\
\hline
\end{tabular}

In the dry farming sections of Eastern Oregon, grain cut green for hay is the most common hay used and probably the best under those conditions for several reasons. In Western Oregon where most of this crop is cut, there is little excuse for the practice and it is diminishing in favor of the superior vetch or clover. Grain hay is used largely at home, on the farm, not marketed. A common mistake in Oregon is to cut grain hay too ripe to get the best quality.

WILD HAY.

\begin{tabular}{|c|c|c|c|c|c|c|c|c|}
\hline Division. & $\begin{array}{c}\text { No. } \\
\text { Reports. }\end{array}$ & $\begin{array}{c}\text { Ave. } \\
\text { Acreage. }\end{array}$ & $\begin{array}{c}\text { No. } \\
\text { Reports. }\end{array}$ & $\begin{array}{c}\text { Ave. } \\
\text { Price. }\end{array}$ & $\begin{array}{l}\text { No. } \\
\text { Reports. }\end{array}$ & $\begin{array}{c}\text { Ave. } \\
\text { Yield. }\end{array}$ & $\begin{array}{c}\text { No. } \\
\text { Reports. }\end{array}$ & $\begin{array}{l}\text { Ave. } \\
\text { Value per } \\
\text { Acre. }\end{array}$ \\
\hline $\begin{array}{l}\text { Coast...... Yialiey } \\
\text { Willamette Vrallen. } \\
\text { Southern Oregon. } \\
\text { Columbia Basin.. } \\
\text { Blue Mountain... } \\
\text { Central Oregon... }\end{array}$ & $\begin{array}{r}23 \\
26 \\
13 \\
2 \\
43 \\
40\end{array}$ & $\begin{array}{r}13 \\
13 \\
27 \\
80 \\
216 \\
181\end{array}$ & $\begin{array}{r}12 \\
4 \\
5 \\
1 \\
12 \\
22 \\
27\end{array}$ & $\begin{array}{r}86.50 \\
8.25 \\
14.00 \\
6.00 \\
8.80 \\
8.21\end{array}$ & $\begin{array}{r}23 \\
23 \\
13 \\
2 \\
2 \\
38 \\
35\end{array}$ & $\begin{array}{l}2.3 \\
1.3 \\
1.8 \\
2.9 \\
1.8 \\
1.2\end{array}$ & $\begin{array}{c}12 \\
2 \\
4 \\
4 . \cdots \\
15 \\
36\end{array}$ & $\begin{array}{r}\$ 10.00 \\
17.00 \\
22.00 \\
\cdots 12.00 \\
12.00 \\
10.00\end{array}$ \\
\hline State Average.... & ........ & 53 & ......... & $\$ 8.30$ & ........ & 1.8 & ......... & $\$ 14.00$ \\
\hline
\end{tabular}


This is still an important crop in the Central Oregon and Blue Mountain meadows where the winter overflow of streams is utilized and where careful irrigation systems have not yet been developedwhere rail transportation is not available and cattle are the chief product. (See table, page 60). This mountain valley wild hay is generally of excellent quality and cheaply produced, but in time it will give way to the higher yielding and better alfalfa, as better irrigation systems are developed.

MISCELLANEOUS CROPS.

Grown Only in Certain Regions.

\begin{tabular}{|c|c|c|c|c|}
\hline Division. & $\begin{array}{l}\text { Average } \\
\text { Acres per } \\
\text { Farm. }\end{array}$ & Average Price. & $\begin{array}{l}\text { Average } \\
\text { Yield } \\
\text { Per Acre. }\end{array}$ & $\begin{array}{l}\text { Average } \\
\text { Value } \\
\text { Per Acre. }\end{array}$ \\
\hline 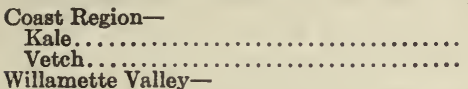 & $\begin{array}{l}1 \\
8\end{array}$ & $\begin{array}{l}\$ 2.50 \text { per Ton. } \\
8.50 \text { per Ton. }\end{array}$ & $\begin{array}{l}31 \text { Tons. } \\
4 \text { Tons. }\end{array}$ & $\begin{array}{r}\$ 87.00 \\
22.00\end{array}$ \\
\hline 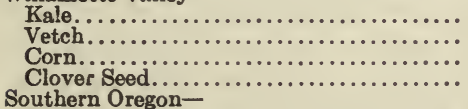 & $\begin{array}{r}2 \\
16 \\
4 \\
20\end{array}$ & $\begin{array}{l}2.50 \text { per Ton. } \\
9.50 \text { per Ton. } \\
.84 \text { per } \mathrm{Bu} \text {. } \\
.15 \text { per } \mathrm{Lb} \text {. }\end{array}$ & $\begin{aligned} & 25 \text { Tons. } \\
& 3 \text { Tons. } \\
& 28 \text { Bu. } \\
& 303 \text { Lbs. }\end{aligned}$ & $\begin{array}{l}53.00 \\
22.00 \\
27.00 \\
31.00\end{array}$ \\
\hline 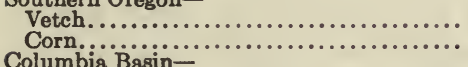 & $\begin{array}{r}19 \\
6\end{array}$ & $\begin{array}{l}12.00 \text { per Ton. } \\
.59 \text { per } \mathrm{Bu} \text {. }\end{array}$ & $\begin{array}{l}2 \text { Tons. } \\
27 \text { Bu. }\end{array}$ & $\begin{array}{l}16.00 \\
28.00\end{array}$ \\
\hline 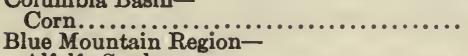 & 20 & .60 per $\mathrm{Bu}$ & $25 \mathrm{Bu}$. & 25.00 \\
\hline 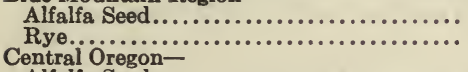 & $\begin{array}{l}35 \\
19\end{array}$ & $\begin{array}{l}.14 \text { per } \mathrm{Lb} \text {. } \\
.93 \text { per } \mathrm{Bu} \text {. }\end{array}$ & $\begin{array}{l}+150 \mathrm{Lbs} . \\
16 \mathrm{Bu} \text {. }\end{array}$ & $\begin{aligned} 20.00 \\
\cdots\end{aligned}$ \\
\hline 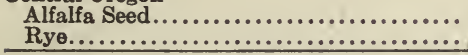 & $\begin{array}{l}14 \\
39 \\
\end{array}$ & $\begin{array}{l}.14 \text { per } \mathrm{Lb} . \\
.93 \text { per } \mathrm{Bu} \text {. }\end{array}$ & $\begin{array}{rl}310 & \mathrm{Lbs} . \\
14 \mathrm{Bu} .\end{array}$ & $\begin{array}{l}40.00 \\
16.00 \\
\end{array}$ \\
\hline
\end{tabular}

"Note:-This yield is below the average of the region.

The crops recorded in this table are grown extensively only in the regions shown, yet are some of the most valuable the state produces. The Thousand-Headed Kale and Smooth Vetch especially are crops peculiar to Oregon and little grown elsewhere, while the clover seed and alfalfa seed are two of the most valuable cash crops of the state.

\section{Field Crops Adapted to Different Districts.}

1. For Humid Districts-Coast, Willamette Valley and Southern Oregon.

\section{A. For Dairy Cows.}

Vetch for hay, green feed or silage.

Clover for hay, green feed or silage.

Alfalfa for hay Southern Oregon, or green feed Willamette Valley and Southern Oregon.

Field peas for hay or green feed.

Kale for winter or summer green feed.

Corn for green feed and silage.

Mangels and turnips for winter green feed.

Field squash for green feed.

Oats and barley for grain feed. 
Rye, oats, barley and wheat in mixtures with vetch for hay or green feed.

Grasses of all kinds and white clover for pasture.

\section{B. For Hogs, Sheep and Poultry.}

All those crops named above for hay, soiling or grain, and in addition, rape, artichokes and emmer.

\section{For Cash Field Crops.}

Clover seed, vetch seed, grass seeds, field pea seed, and field beans, except on the coast.

Potatoes and all other grains and hays, except alfalfa on the coast.

2. For the Irrigated Districts-Eastern Oregon.

All the same crops as those named for the humid districts except kale as fall feed only and excepting smooth vetch, field beans and clover seed.

3. For the Dry Farming Districts-Eastern Oregon.

All the crops named for the humid districts but kale only as a fall feed, no vetch, no field beans, no clover and no mangels. Under the dry farming conditions alfalfa and field peas are grown in cultivated rows largely for seed or hog pasture, and field corn for "hogging off," and flax for seed, white turnips and field squash are little grown. The small grains are the major crops, among which the emmer is displacing the oats, while the hardier sorghums are developing as fodder crops.

\section{Field Crops Not Grown in Oregon.}

There are few field crops that are not successfully produced in Oregon. In Western Oregon, flax for fibre of unusual quality and in Eastern Oregon first class sugar beets have been grown, but both of these crops require an abundant supply of cheap labor not found here as yet. Cow peas are not grown successfully but field peas are one of the very best of Oregon crops. Soy beans are just beginning to be grown but are not fully adapted as yet to Oregon conditions. Field beans are raised very profitably in the Southern Oregon section. Corn, especially for green feed, silage and "hogging off," is in recent years grown very profitably, but since most of the crop is utilized in these forms instead of in the ear, the tables of production do not show the importance of the crop.

\section{Rotations and Cropping Systems for Oregon.}

All the essential legumes, cultivated crops, cover crops, green manures, catch crops, nurse crops, etc., required to form rotations adapted to every purpose and to every soil and climatic condition in the state,-are available to Oregon. The best of rotations for maintaining fertility are possible in every section and Oregon soils, still with a wealth of natural fertility, respond quickly to good rotations. Such soils as have been cropped continuously for many years show the abuse only in a decreased 'humus content and undesirable physical condition, both of which are quickly restored by the use of a good rotaion. Practically no commercial fertilizers are 
required and this is of special importance to the general farmer who cannot afford costly fertilizers. Phosphorus, the plant food element which must generally first be replaced through commercial fertilization, is unusually abundant in most Oregon soils. Lime, which plays an important part in fertility, is abundant in all Eastern Oregon soils, but in Western Oregon-as in nearly all humid soils-is scanty. But large lime deposits are available for correcting this deficiency.

Cropping systems for supplying green feed for dairy cows continuously throughout the year are one of the unique features of the Western Oregon dairy farm. On the higher priced lands closer in, such a system permits very intensive dairying, maintaining a cow to every acre where the system is fully developed, and steadily increasing fertility. Under favorable conditions it requires only four cropssmooth vetch, alfalfa, corn and kale-to furnish such continuous green feed.

Rotations or cropping systems for hogs, which carry the animals from farrowing through the finishing period without leaving the pasture until they go to market, are possible both in Western and Eastern Oregon-the "hogging off" of vetch, clover, alfalfa, field peas, rape, artichokes and corn being very profitably practiced. Similar rotations for sheep and poultry permit handling all of these animals on a like intensive scale. The irrigated areas as well as the dry farming lands have available such cropping systems and fertility rotations as fit their special requirements.

For the farmer who wishes to grow field crops only (and this is most attractive of all types of farming for the man of small capital who must have immediate returns) the list of cash crops successfully grown in Oregon is unusually good. No better crops than clover seed, vetch seed, grass seeds, ficld pea seed, field beans, alfalfa seed or potatoes can be found either for profits or fertility.

Note the map indicating the six great geographical subdivisions of the State. This is something like dividing animals into general families; the cat family, the dog family, the horse family, etc. There is still a big difference between the lion and a house-cat, and you must not expect uniform conditions throughout the whole of any of these great subdivisions of our State. For detailed descriptions of each section in each County, consult the Oregon Almanac.

The disappointed homeseeker is worse than a poor advertisement. He discourages his neighbors and scatters seeds of failure. The State of Oregon does not wish to bring people here only to disappoint them. We want everybody to know the facts and prefer to under-state rather than to over-state. 
WIDE VARIATION OF RAINFAIT.

In the thickly populated interior vallejs of Western Oregon, the precipitation is about the same as in the Atlantic and Central states (New York, 44.8; Chicago, 33.4; Des Moines, 32.4).

In Eastern and Central Oregon the rainiall is about the same as in Colorado, Montana, Utah, Western Texas and the Coast counties of Southern California. (Donver, 13.7; S\&lt Iake City, 15.8).

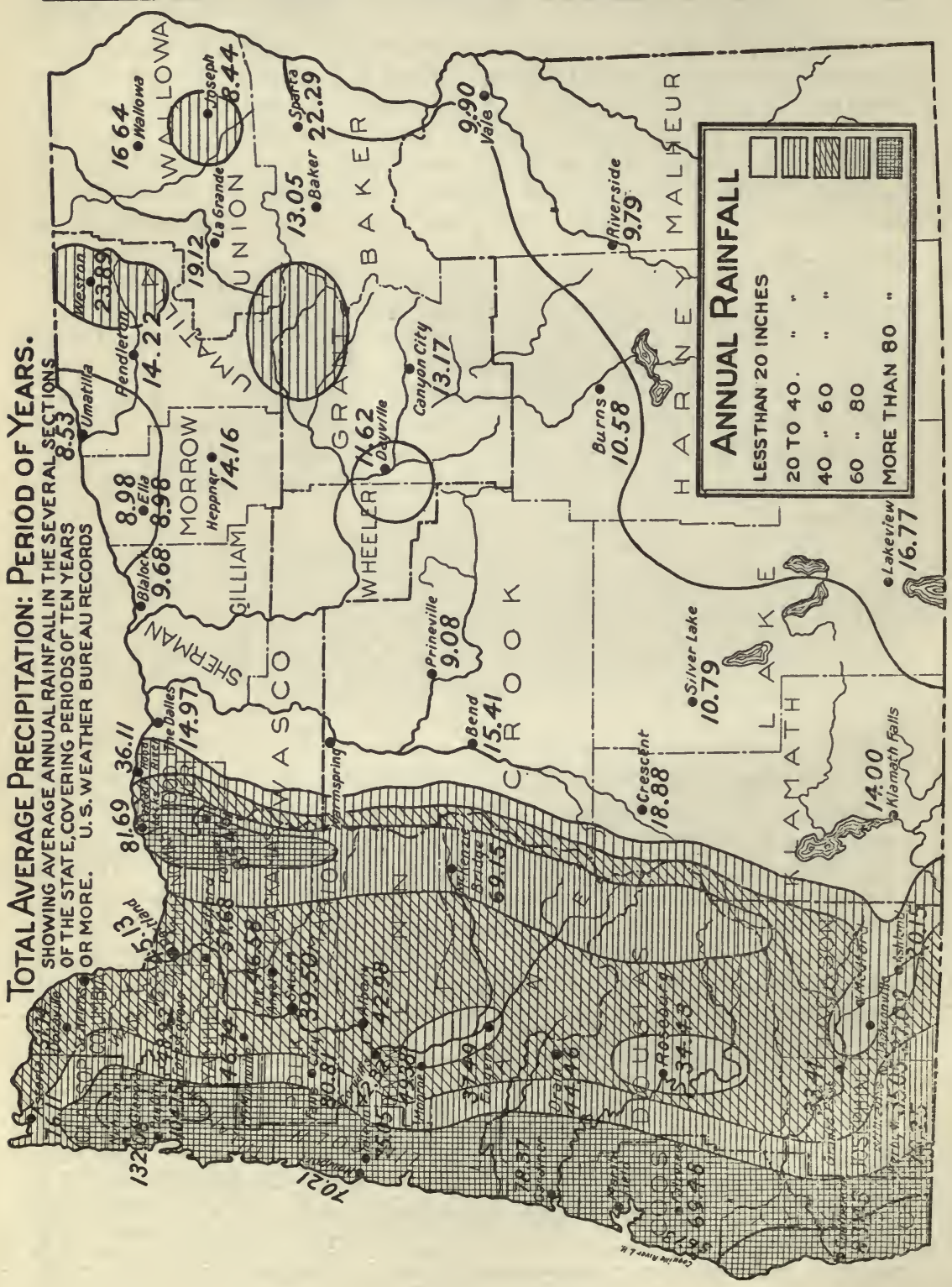




\section{THE CLIMATE OF OREGON.}

By W. L. Powers,

Assistant Professor of Irrigation and drainage.

(2MONG the factors influencing the agriculture and healthfulness of a state none is more important than climate. The determining factors of a climate in Oregon are chiefly the altitude, nearness to the ocean, prevailing winds, and movements of general storm areas. The wide variations of these conditions in Oregon cause a great diversity of climate and makes possible the production of practically everything grown outside the tropics.

\section{General Topographic and Climatic Conditions.}

The chief topographic features of the state are portrayed by the accompanying rainfall chart of the Weather Bureau, page 64, and the topographic map, which we are permitted to reproduce thru the courtesy of our District Forecaster, E. A. Beals, of Portland (Enclosed). The natural drainage for most parts of the state is northerly into the Columbia or else westward into the ocean. The lofty snowcapped Cascade Range, 5,000 to 10,000 feet in elevation divides the state north and south and serves as a natural barrier in winter between the warm air of the western valleys and the cool air of the plateaus to the east. East of this range the climate is continental in character and is semi-arid with large daily range of temperature, cool nights and a preponderance of clear days. The climate of Western Oregon is characterized by its mild moist winter season and bright mild summers with a remarkably long growing season. The Cascade and Coast Ranges cause heavy precipitation in winter from the moist winds and storm areas which blow prevailingly from the southwest off of the ocean.

The mean annual rainfall from stations of the United States Weather Bureau with records over 10 years in length is shown on the topographic map. In general the rainfall decreases from northwest to southeast across the state and increases on the windward slopes of all mountains. The range is from 132 inches at Glenora on the coast mountains in the northwest part of the state to 10 inches at Vale in Malheur, the southeastern county. The mean rainfall of the valleys in Western Oregon is similar to that of New York; while that of Eastern Oregon is about the same as Denver and Boise.

The main distinguishing feature of the temperature of the state is the cool nights of summer which insures complete rest after hard labor. The mean temperature varies with altitude and distance inland. In the agricultural valleys in Western Oregon and below 2,000 feet elevation the mean temperature is about 52 degrees, which is the same as at Bloomington, Ill., and Columbus, Ohio. The mean temperature of Eastern Oregon ranges from 56 degrees along the Columbia to 44 degrees in Southeastern Oregon.

Most parts of the state are free from high winds. The absolute maximum velocity recorded is 55 miles per hour. The heavy winter rainfall of western sections of the state is well distributed, the greater 


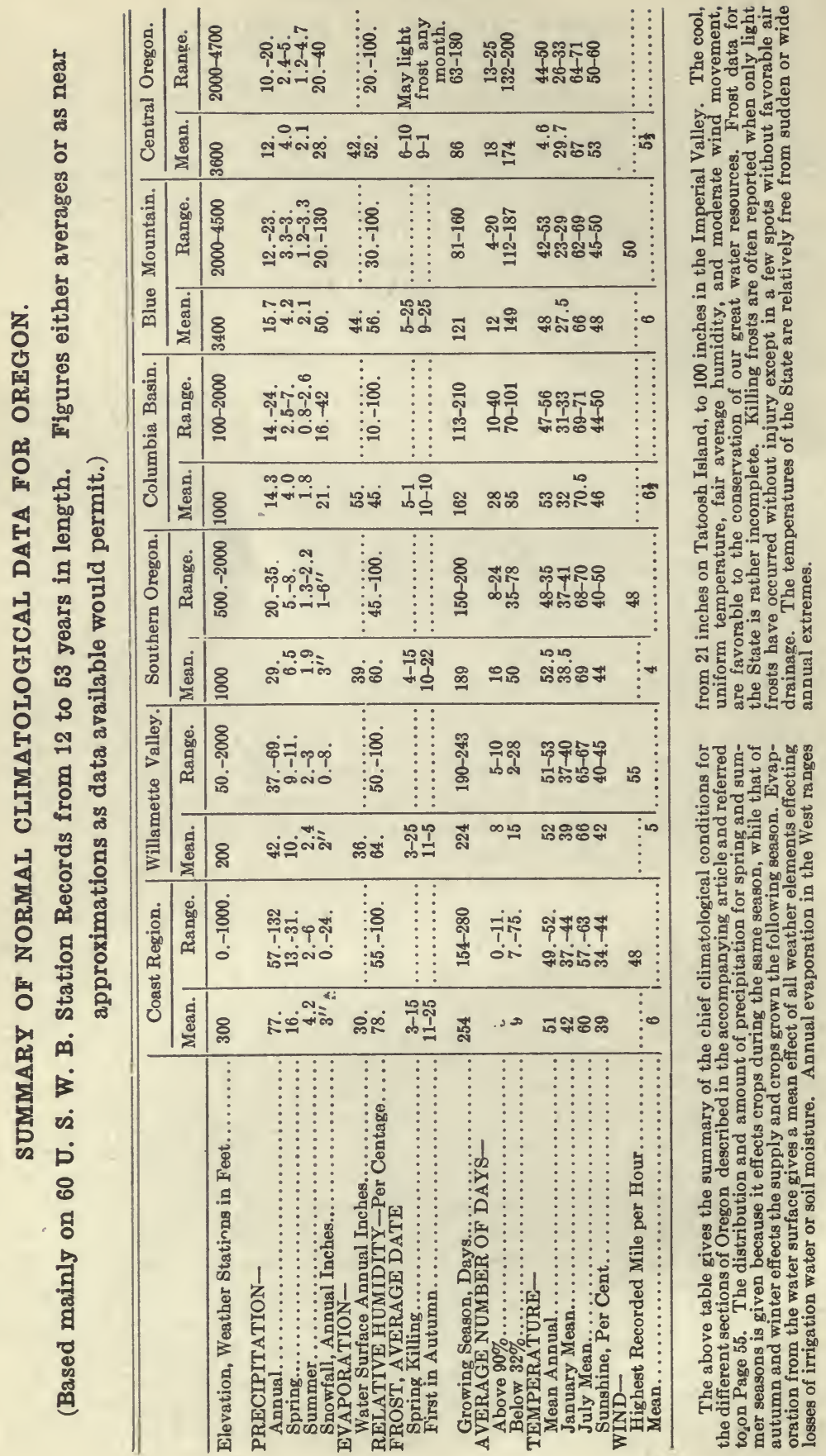


part falling at night, so that disastrous floods are practically unknown. The weather records show but one severe wind, and few injurious hail-storms, which were of a local character. The state is free from tornadoes, earthquakes and electric storms.

The yearly average number of thunder storms is 8 for Eastern Oregon and 3 for Western Oregon. They usually consist of but two or three flashes and are observed in mountainous districts. Data in the accompanying table is arranged to show the average and range of climatic conditions for the 6 chief sections of the state (page 66).

\section{The Coast Region.}

The Coast Range has an average altitude of 2,000 feet and parallels the sea at a distance of 30 to 40 miles separating the humid coast region from the semi-humid valleys to the east. The agricultural districts of the coastal plain vary in elevation from near sea level to 1,500-2,000 feet. The annual rainfall averages some 77 inches and varies with altitude.

It reaches a maximum at Glenora of 132 inches and a secondary maximum of 83 inches in the southwest coast hills. There is a high relative humidity and fogs are frequent and the grass is green throughout the year. The chief characteristics of the climate is the strikingly uniform temperature which permits a remarkably long growing season, averaging 265 days, or about 8 months. The season is longest near the shore and decreases with altitude. The temperature along the coast has never been higher than 97 degrees or lower than 10 degrees above zero. The mean July temperature, 65 degrees, is about the same as at Duluth, Toronto and Montpelier. The mean January temperature, 40 degrees, is the same as that of Vicksburg and Montgomery. There is no snow except on the hills and that goes off in a day or two except on the highest peaks.

\section{The Willamette Valley.}

Between the Coast and Cascade Ranges lies the great valley of the Willamette which flows north emptying into the Columbia near Portland and has a drainage area of 12,000 square miles. The mean elevation of the floor of this valley is about 200 feet, ranging from 57 feet at Portland to 450 feet at Eugene. Rainfall averages about 42 inches, similar to that of Springfield, Missouri, and Indianapolis, Indiana. Rainfall decreases slightly as we go up the floor of the valley and increases rapidly going up the mountain slopes to the east. The winter rain is of sufficient abundance to more than saturate the deep soil. There is a few inches of snow some winters but it melts away in a day or two. The growing season is remarkably long, averaging 210 days. The minimum January temperature is similar to that of Chattanooga, Tenn., Lynchburg, Va., or New Haven, Conn. The absolute range of mean temperatue for July is 8 degrees, while for Iowa this is 13 degrees. The average annual number of days above 90 degrees is 8 and below 32 degrees is 15 . There is about the same percentage of sunshine as in New York state. The climate is moist 
and mild in winter and cool in summer, but is a little more seasonal than on the coast.

\section{Southern Oregon.}

Irregular offshoots and spurs of the Coast and Cascade Ranges spread out in the southwestern part of the state, forming a more elevated undulating section with somewhat less humid and more sunny climate. The rainfall averages about 30 inches and runs from 35 at Roseburg to 21 at Ashland. About 2 inches falls during the three summer months. There is an average of about 185 days between killing frosts, being similar to that of Central Illinois. The length of season depends on the altitude and the natural air drainage, and ranges from 150 to 200 davs. The mean temperature for January is about 40 degrees and for July about 60 degrees. There are 16 days in a year when the temperature rises above 90 degrees and 50 days when if falls below 32 degrees. The climate is somewhat more seasonal than for the Willamette Valley but it is free from extremes of any kind. The winters here are mild and the summer nights cool.

\section{Columbia Basin.}

East of the Cascades is the Columbia River Basin, 50 to 75 miles wide and about 150 miles long. It has a mean elevation of about 1,000 feet and a general northernly dip towards the river. Here the climate is dry and sunny. The relative humidity is low and evaporation from a water surface is high. The annual rainfall for the district averages some 14 inches ranging from about 10 inches near the river on the Umatilla irrigation project to 24 inches at Weston. Rainfallincreases with altitude and distance from the river. While the heaviest rains are in winter there is a secondary maximum in May and June. In the foothill districts these early summer rains come as torrential showers. The mean annual temperature near the river reaches 56 degrees, the highest for the state. It decreases with altitude to 47 degrees in the foothills of the Blue Mountains. There is a very long growing season along the Columbia, averaging about 200 days. The average for the district is about 157 days, corresponding to that of southern Wisconsin. Strong breezes are common along the river but decrease upon going back from the river and to higher altitudes. The nights are cool, the days clear and the air fresh and invigorating.

\section{Blue Mountain District.}

In Northeastern Oregon is situated the high irregular range of the Blue Mountains, between the various groups of which very productive elevated valleys are situated. These and the other scattering mountains of Eastern Oregon cause precipitation of the limited supply of moisture which escapes the Coast and Cascade Ranges. The rainfall ranges from 12 to 23 inches and averages about 16 inches annually The growing season ranges from 100 to 150 days, averaging about 140 days in the valleys and decreasing with the altitude. There are many sheltered valleys where the season permits commercial fruit growing. The mean summer temperature corresponds to central Wisconsin and that of winter is similar to northern Iowa. 


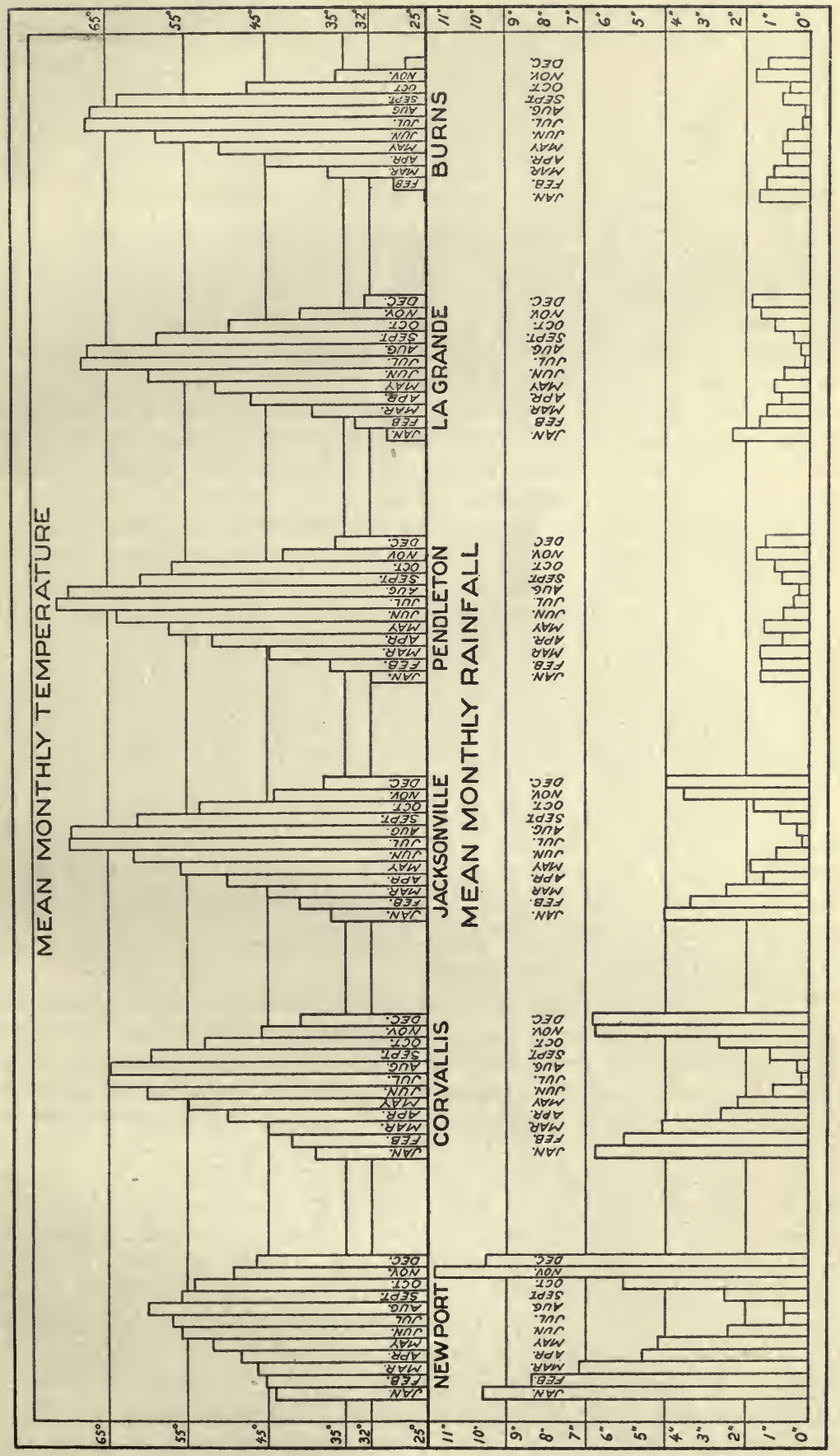


The mean annual temperature is about 48 degrees. The temperature rises above 90 degrees about 12 different days in the year and reaches the freezing point on about 150 days. There is more rainfall and less sunshine than in the Columbia Basin but the temperatures average lower at the higher altitudes and are subject to greater range.

\section{Central Oregon.}

The Central Oregon country is mainly a great elevated plain with an average altitude of about 4,000 feet. The summer nights are cool, the rainfall is low and the sunshine abundant. The air is fine and the climate corrective to tuberculosis tendencies and more invigorating than the hot semi-arid sections of the southwestern states. On these plains the growing season is from 65 to 135 days and the rainfall 11 to 14 inches. In the interior part of this region are numerous lakes without any natural outlet and these modify the temperatures of the immediately adjacent lands, so that fruit is produced in favored spots.

The northern edge of the region is drained by the Deschutes River. This valley averages about 3,000 feet in elevation and has a growing season of ten weeks to four months and a rainfall of about 12 inches in the floor of the valley. Rainfall increases up stream and up the foothills at the sides of the valley. Large areas are irrigated.

The lower irrigated valley and bench lands of northern Malheur County have a mean elevation of about 2,200 feet and this together with their favorable latitude causes a growing season of five to six months, so the data in the table does not apply. The rainfall is about 10 inches.

In the southwestern part of this region the Lake district has an altitude of about 4,100 feet. At Lakeview and Klamath Falls the growing season is some 130 days. The rainfall at Klamath Falls is 13.5 inches, 17 inches at Lakeview and 11 inches at Burns. Large areas tributary to these points are irrigated.

\section{The Chief Districts Compared.}

The mean monthly and yearly temperatures from selected stations of the Weather Bureau in each of the chief geographic sections of the state are compared graphically in the accompanying diagram (Page 69). The bars show an increase in range of temperature as we go to the south and east to higher altitudes and to regions more distant from the ocean.

The lower bars show the relative amount and distribution of rainfall for the same stations. The rainfall for La Grande is about 2.2 inches below average for the district and is misleading in that the average rainfall for the Blue Mountain district is about 2 inches above that of the Columbia Basin. In the western sections of the state the bulk of the rainfall comes between October and March and there is but light rainfall in summer, caused by the shifting of the storm areas and areas of high pressure or clear weather. In Eastern Oregon the maximum rainfall is in winter with a secondary maximum as shown for May and June. 


\section{FRUITS AND VEGETABLES IN OREGON.}

By C. I. Lewis,

Professor of Horticulture.

TG ORTICULTURALLY speaking, Oregon is a state of great diversity. Apples, pears, prunes, walnuts, Loganberries, small fruits, and garden truck are grown in great abundance. While it is true that the apple has been advertised more than any other fruit in the state, nevertheless according to the latest census, the apple is surpassed in increased production during the last decade by the pear, prune, and cherry.

From the earliest plantings to the present time, the fruit of this state has attracted world-wide attention and the industry has grown in magnitude and profit until it is now becoming one of considerable importance, and in a few years fruit promises to become one of the leading outputs of the state. The development of the fruit industry in this state is due to a genial combination of climate and soil conditions which insure regular heavy crops containing a large percentage of fruit of high color, good size, and free from blemish. Such fruit is commanding the top prices in the world's markets.

Co-operation is a great factor in Oregon fruit production. Probably no region in the United States has had a more successful demonstration of the possibilities of co-operation in fruit production. The opportunity for co-operation, coupled with the general personnel of those engaged in fruit growing, are very important factors in the development of horticulture in this state. In addition to this the fact that horticulture has become highly specialized has given a combination of producing and handling that is hard to excel.

FRUIT-STATE AVERAGE 1910-11.

\begin{tabular}{|c|c|c|c|c|c|c|}
\hline & Reports. & Acres. & Total Crop. & Per Acre. & $\begin{array}{c}\text { Average } \\
\text { Price. }\end{array}$ & $\begin{array}{c}\text { Income } \\
\text { Per Acre. }\end{array}$ \\
\hline 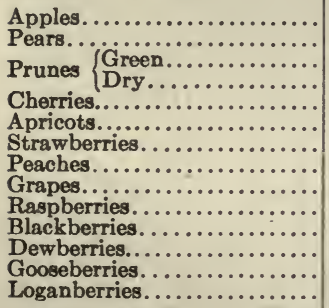 & $\begin{array}{r}364 \\
91 \\
187 \\
116 \\
2 \\
82 \\
103 \\
23 \\
31 \\
7 \\
3 \\
5 \\
2\end{array}$ & $\begin{array}{r}1,658 \\
380 \\
1,778 \frac{1}{4} \\
91 \frac{1}{4} \\
2 \\
126 \frac{3}{4} \\
409 \frac{1}{2} \\
95 \\
16 \\
7 \\
4 \\
1 \frac{3}{2} \\
83 \frac{1}{4}\end{array}$ & 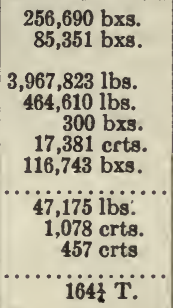 & $\begin{array}{r}155 \mathrm{bxs} . \\
224 \mathrm{bxs} . \\
2,231 \mathrm{lbs} . \\
5,092 \mathrm{lbs} . \\
150 \mathrm{bxs} . \\
136 \mathrm{crts} . \\
254 \mathrm{bxs} . \\
2,947 \mathrm{lbs} . \\
168 \mathrm{crts} . \\
114 \mathrm{crts} \\
2 \mathrm{~T} .\end{array}$ & $\begin{array}{c}.041 \\
.045 \\
1.00 \\
1.85 \\
.734 \\
\ldots .09 \\
1.05 \\
2.00 \\
\ldots 82.45\end{array}$ & $\begin{array}{r}\$ 241.10 \\
262.08 \\
129.33 \\
91.47 \\
229.14 \\
150.00 \\
251.60 \\
186.44 \\
283.93 \\
247.35 \\
275.52 \\
228.00 \\
378.80 \\
164.90\end{array}$ \\
\hline
\end{tabular}

The Oregon apple is known the world over. Especially is this true with such varieties as the Yellow Newtown, and Esopus Spitzenberg. Other varieties, such as Arkansas Black, Winter Banana, Delicious, Rome Beauty, Jonathan, Winesap, and Gravenstein, are 
grown commercially. Nearly every fruit valley of the state is producing apples, it being merely a question of securing a good location and adopting the proper varieties. There are only a relatively small percentage of the apple trees in the state in bearing and the next decade promises a remarkable increase in bearing trees and in the apple output.

In pear production Oregon stands fourth in the Union in yield and second in number of young trees. It is only a question of a short time before this state will prohably lead the Union in the production of this fruit. The state is peculiarly fortunate in having a considerable area of land coupled with favorable climatic conditions, making it possible to grow this fruit. In most regions of the country pear growing is on the decline and those regions therefore which are specially adapted to the production of this fruit are finding it to be very profitable. Up to the present time a large proportion of the crop has been boxed and sent to the leading markets in this country and in Europe. The next decade will see considerable development in the growing of pears for canning.

Seventy-five per cent of the tart prunes that are grown in the United States are produced in Oregon, the Italian being the leading variety. Some of this fruit is shipped green to eastern markets, but the larger percentage is evaporated and sent to those portions of the world that prefer a tart to a sweet prune. With a closer organization of growers and a standardization of product, both of which are being attempted, the prune industry should in the near future develop even greater than it has in the past. This is one of the easiest tree fruits to grow and one which adapts itself nicely to diversified farming, the prune being on many an Oregon farm the best cash crop produced. It also lends itself nicely to diversified horticulture, while on the other hand some sections of the state are making prunes the special crop.

Only two or three states in the entire Union are building up a sweet cherry industry. As regards the excellence of the sweet cherry produced in Oregon, it is unsurpassed by that of any region in the United States. The Bing in Eastern Oregon, the Napoleon (Royal Anne) along the Columbia Basin, and the Lambert in Western Oregon, grow to perfection. These cherries grow to a very large size, have firm flesh, and small pit, and have been shipped to Mexico City, Liverpool, and Alaska successfully.

The sour, or pie, cherry industry as yet has not developed very materially in this state, but it is only a question of a short time before the industry will be of considerable importance. The fruit grows very easily in practically all fruit districts of the state and canning factories are demanding much larger quantities of this fruit than can be supplied.

In the Loganberry we practically have a new fruit. This is a cross between the blackberry and raspberry. Canned it is most excellent, being splendid for pies and sauces, makes a fine jelly, and its juice by 
many people is thought to be superior to that of the grape. This berry is adapted to only a few Pacific Coast localities, and in Western Oregon reaches its highest degree of perfection. This berry the past few years has proved to be one of the most profitable crops grown in the entire state of Oregon. With proper organization of growers and distribution it will mean millions annually to the state. It is a crop which can be combined very nicely with prune production, as it can be easily evaporated in the same buildings that are used for the drying of prunes. Some men are specializing in Loganberries entirely, but the crop is one which lends itself to diversified farming very nicely.

English walnuts and filberts are being planted quite extensively throughout the state. The French strains of the walnut, like the Franquette, Mayette, and Meylan are the favorites at the present time and the industry promises to become much larger in Western Oregon. While at present the output is small, in the near future it will be materially increased, as a large acreage of young trees is just coming into bearing. Oregon walnuts are noted for superiority in flavor, and those so far produced have brought much above average prices on the nut markets.

Peaches are grown largely as fillers, there being only a few sections where this fruit is grown as a specialized crop. While shipments have been made to Mississippi River points, the bulk of the crop is grown largely for local consumption or for canning.

In the production of cane fruits the state is unexcelled. Red raspberries yield regular heavy crops, as high as 600 crates per acre being reported. Blackberries, gooseberries, currants, and strawberries are all grown readily and cheaply. Strawberries and raspberries are shipped from Pacific Coast points as far east as Chicago.

Other fruits, such as almonds and apricots, are grown in limited quantities, and those interested in them can find regions specially suited for their successful production.

The by-products industry is one which promises in the very near future to reach a considerable magnitude. Thus far the development has been largely in Western Oregon in such cities as Eugene, Corvallis, Salem, Portland, and vicinity. In the cherry districts there is a very heavy demand for Napoleon (Royal Anne) cherries for Maraschino. Many of the canneries in the state are co-operative. The great diversity of crops, the abundance and ease with which they can be produced, combined with the co-operative plan, whereby the producers share all the profits, gives very satisfactory results, and extensive plantings are taking place wherever the canneries and byproducts plants are being established.

In dried fruits, especially the prune, the state has built up a very strong industry. Apples, pears, and peaches are being dried in limited quantities. 
VEGETABLES-STATE AVERAGE 1910-11.

\begin{tabular}{|c|c|c|c|c|c|c|}
\hline & Reports. & Acres. & Total Crop. & Per Acre. & $\begin{array}{c}\text { Average } \\
\text { Price. }\end{array}$ & $\begin{array}{l}\text { Income } \\
\text { PerAcre. }\end{array}$ \\
\hline 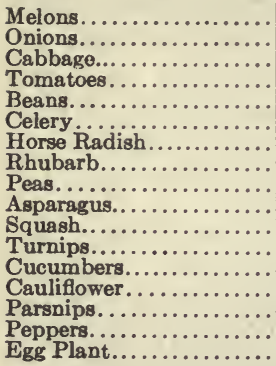 & $\begin{array}{r}27 \\
65 \\
37 \\
28 \\
41 \\
8 \\
1 \\
11 \\
1 \\
6 \\
13 \\
20 \\
1 \\
7 \\
2 \\
5 \\
2 \\
2\end{array}$ & $\begin{array}{c}85 \frac{1}{2} \\
137 \\
27 \frac{3}{6} \\
11 \frac{1}{2} \\
68 \\
11 \frac{8}{6} \\
16 \\
9 \frac{1}{4} \\
9 \frac{1}{2} \\
8 \frac{1}{47} \\
2 \\
1 \\
1 \\
7 \\
.7 \\
.62\end{array}$ & $\begin{array}{c}12,910 \text { crts. } \\
40,017 \text { sks. } \\
270 \text { tons. } \\
9,286 \text { bxs. } \\
63,967 \text { lbs. } \\
17,900 \text { dz.bun } \\
48 \text { tons. } \\
208,000 \text { lbs. } \\
21,492 \text { lbs. } \\
29,057 \text { lbs. } \\
75,000 \text { lbs. } \\
250 \text { sks. } \\
173 \text { bu. } \\
175 \text { crts. } \\
14,100 \text { lbs. } \\
203 \text { crts. } \\
200 \text { crts. }\end{array}$ & $\begin{array}{c}151 \text { crts. } \\
292 \text { sks. } \\
9.7 \text { tons. } \\
807 \text { bxs. } \\
940.6 \text { lbs. } \\
1,512 \mathrm{dz} \text {. bun } \\
3 \text { tons. } \\
22,486 \text { lbs. } \\
2,262 \mathrm{lbs} . \\
8,940 \mathrm{lbs} . \\
15,284 \text { lbs. } \\
125 \text { sks. } \\
173 \text { bu. } \\
175 \text { crts. } \\
16,114 \text { lbs. } \\
271 \text { crts. } \\
322.6 \text { crts. }\end{array}$ & $\begin{array}{c}\$ 1.67 \\
1.94 \\
31.73 \\
.57 \\
.044 \\
.63 \\
140.00 \\
.024 \\
.043 \\
.055 \\
.093 \\
1.00 \\
1.41 \\
1.35 \\
.015 \\
.60 \\
1.00\end{array}$ & $\begin{array}{r}\$ 252.17 \\
566.48 \\
307.78 \\
459.99 \\
413.86 \\
952.56 \\
420.00 \\
539.66 \\
97.26 \\
491.70 \\
46.15 \\
125.00 \\
243.93 \\
236.25 \\
241.71 \\
163.90 \\
322.60\end{array}$ \\
\hline
\end{tabular}

Note:-Some of the yields are a little high owing to the fact that many patches were small and given extra good care.

In some cases prices are above the average owing to the fact that the produce was disposed of locally to good advantage.

Truck gardening has not been developed to the same extent as has fruit growing. In the production of onions, however, the state surpasses, and most years this industry is found to be very profitable. Most of the onions are produced on what is known as the beaverdam lands, which abound in Western Oregon. Broccoli, or winter cauliflower, grows exceedingly well and it is only a question of a short time before the state should ship out a large amount of this vegetable. The opening of the Panama Canal should make it possible to place vegetables in eastern cities in good condition at low costs. While the markets are fairly well supplied with rather low grade vegetables, there is a splendid opportunity in the state for the production of high class vegetabes.

There are at the present time relatively few truck gardeners who have made this subject a specialty. Only occasionally does one meet the intensive growers found in the environments of large eastern cities.

The greenhouse business has grown very rapidly the last few years and offers a most attractive field of investment for people who have been trained in this line of work. All over Western and Southern Oregon, especially where the centers of population are increasing rapidly, there is a brisk demand for greenhouse products. The business is twofold, flowers such as the carnation and chrysanthemum on the one hand, and vegetables such as tomatoes and cucumbers on the other hand. For the latter there is a very strong demand, owing to the fact that the climatic conditions are such in many portions of the state that there is a good profit in growing tomatoes under glass, much more so than when grown outside. In most parts of the state the climatic conditions are so mild that greenhouse production is cheaper than in most eastern states. There are a number of cases in the state where men with a capital of $\$ 600$ to 
$\$ 2,000$ have built up an industry which is making them independent.

The nursery business during the past few years has assumed enormous proportions. One of the largest nurseries in the United States is located in this state. The diversity of horticulture has made the nursery business a good one, there being a demand for many kinds of fruit and ornamental trees and plants. The reputation of the state for fruit production has induced many people in various parts of the United States to patronize Oregon nurseries for their stock. (In Eastern Oregon, under irrigated conditions, piece root trees are grown very successfully, while in Western Oregon, the whole root or budded trees grow to better advantage.)

The prospective settler is always interested in the prices of fruit lands, and it is generally believed by many that it is impossible to buy cheap lands in Oregon. It is true that in some sections of this state land has probably been sold for prices that were unwarranted. However, orchards which have been well selected and properly cared for are producing good interest on a valuation of $\$ 1,000$ per acre, and some on an even greater valuation. The price of land is fixed by many factors, such as transportation, nearness to rapidly growing centers, the size of the area that is being planted to fruit, all have a bearing on the price.

In regions where horticulture has become highly specialized the prospective settier must naturally expect to pay more for land than in those localities where less development has taken place. However, it is not necessarily true that the cheaper lands are the best to buy. There is to be found in this state today, an abundance of splendid fruit land for sale for less than $\$ 100$ per acre. In fact, large areas can still be purchased for as low as $\$ 50$ per acre. The region in which one will wish to purchase will depend first of all on the choice of an irrigated or non-irrigated tract, climatic preference, or the greatness of the desire to be near magnificient scenery.

Failure in the fruit business is not unknown. Such failures as occur are due to such factors as improper choice of orchard site, the adoption of questionable horticultural methods, the planting of unsuitable varieties, and the use of poor business judgment. Where suitable locations are chosen, proper orchard methods employed, and sound business methods practiced, fruit growing is found to be a very profitable business.

Many prospective fruit growers contemplate buying too small holdings. It is true that under proper conditions the small tract of say ten acres is found to be very satisfactory. This is true in those regions of good soil where irrigation can be obtained to supplement the rainfall, or on the non-irrigated river bottom soil, which is alluvial and somewhat sandy in nature, and has a wide range of adaptability. Under such conditions ten acres can be made to produce a relatively large income. To the average man, of limited means, it will be better to try and secure a larger acreage. Forty acres in many cases will be a desirable tract to purchase, this being approximately about a oneteam unit. That is, one man and a pair of horses could do the greater 
part of the work from early spring to early August, this being the rush season. The first few years a portion of the land can be set to tree fruits, and an area reserved for vegetable gardening and small fruits. Chickens, hogs, and the family cow can be used in this combination to very good advantage. After the entire acreage has been planted and has come into bearing, twenty acres could be disposed of and the capital thus secured invested in better buildings and needed improvements.

When the settler starts in this way he is assured of a good living, a steady income, and a rapid increase in value of the land in which he has invested and which ultimately will become a unit which should insure success. Where feasible it will be well to grow more than one type of fruit, though, in some regions soil and climatic conditions are more favorable to the production of a relatively few varieties.

Irrigation is a factor in fruit production in the state of Oregon. In such regions as the Umatilla Project, including Hermiston and Stanfield, and in parts of Eastern Oregon, irrigation becomes a necessity where commercial fruit growing is to be undertaken. On the other hand in most of the fruit valleys, such as the Grande Ronde, Walla Walla, Hood River, and Rogue River, irrigation is used to supplement the rainfall and in these regions many orchards have never been irrigated. Fruit growing can be undertaken successfully in such regions without irrigation provided good soil is chosen and proper cultural methods are adopted. In many cases, however, supplemental irrigation will be found to be of great help.

The question of varieties to plant is largely a local one. There is not a fruit valley in this state but what can produce fruit to a high degree of perfection. Choose good soil, put into play up-to-date methods, and choose the varieties which are succeeding the best in your locality, should be the rule to follow. The Experiment Station issues, from time to time, lists of varieties which are recommended for various parts of the state.

In no region of the world is horticulture becoming more specialized and intensified than in the state of Oregon. Fvery effort is made by the growers to apply the most up-to-date and improved methods. The most common method used in handling the soils of the orchards is that of clean tillage. Nearly all the orchards are plowed and harrowed carefully each year and are cultivated at such frequent intervals as to prevent the ground baking, the escape of moisture or growth of weeds. The amount of tillage varies in the different localities, and is controlled by such factors as, climate, soil, variety of fruit, and age of "tree.

- Cover crops are used very extensively in bearing orchards in nonirrigated districts, while in the irrigated districts either cover crops are grown, or else orchards are permanently seeded to clover, alfalfa and similar crops. This system is adapted only to regions where they are "supplied "with irrigation water.

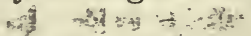

Spraying is a universal practice and nearly every orchard is provided with a power sprayer, and the orchard is given a regular, systematic 
series of sprayings. Many pests, however, that are common in the east are not found in Oregon, such as the plum curculio, for example, which makes it so difficult in some sections of the United States to produce stone fruits.

The thinning of tree fruit is a universal practice. With apples, pears and peaches, thinning is done by hand, while with cherries and prunes most of the thinning is done by pruning.

Oregon was the first state in the Union to perfect the box system of packing, and its system of grading and packing is now recognized as the best in the world and is being copied to a certain extent by many other fruit growing regions.

A recent development in fruit production in this state is the erection of large cold storage houses. These will enable the fruit growers to hold their crops until such times as they can dispose of them on the market to the best advantage. Up to the present time the state has been very fortunate in meeting with very hearty cooperation on the part of all transportation companies in the way of rates, storage in transit facilities, icing facilities, and in rolling stock.

Those who love attractive home surroundings will find Oregon an ideal location. In the greater part of the state the climatic conditions are such as to insure the successful culture of a wide range of plants. Not only is the state rich in beautiful native trees, shrubs and flowers, but practically everything grown in the temperate zone will succeed here. This wealth of material offers superb combinations of plants that give a pleasing landscape picture. This coupled with a magnificent view through a vista of tall fir trees of perpetual snow-capped peaks, tinted rose by the setting sun, appeals to all lovers of the beautiful in nature. Rare sunset effects are found in our beautiful foothills; combinations of shades of green, blue, purple, and rose such as are indescribable are seen daily.

\section{Coast Division.}

\section{DISTRICT REPORTS.}

The Coast Division has not been developed horticulturally as much as some other districts in the state However, there are splendid opportunities for increased production along certain lines.

Gravenstein apples are grown to an unsurpassed degree of excellence and are noted for their fine color and wonderful keeping qualities. Such apples have been shipped from Coos Bay to New Zealand, Australia, and Alaska. This region also has splendid opportunities for cranberry growing, there being considerable wild area having the natural requirements of soil and moisture. These peat bogs quite often are supplied with living streams of water and generally have an abundance of sand in their vicinity, thus giving ideal conditions. Wherever the cranberry has been tried under suitable conditions it is giving very satisfactory returns, now indicating that cranberry growing in the Coast Division will become an 
industry of considerable importance to the state. The greatest development at the present time is in Coos, Tillamook, and Clatsop Counties.

Probably no region of the state can surpass the Coast Division in the production of small fruits. The bench lands produce strawberries from May until late in the fall and early winter, and the rich moist loams are unexcelled for the growing of cane fruits such as blackberries, Loganberries, and raspherries. Such fruits should be produced in large quantities cheaply for canning factories or evaporators.

Certain types of truck, such as turnips, cabbage, cauliflower, and broccoli, do specially well on the bottom lands.

\section{Southern Oregon District.}

This is divided into two sections; first, Douglas County, which includes the Umpqua Valley, and Jackson and Josephine Counties, which include the Rogue River Valley.

Douglas County is in one of the earliest regions in the state and offers an inviting field for the production of early garden produce and fruits. Early strawberries, cherries, and vegetables that reach many of our markets come from this section. It is also noted for the production of French prunes, and a considerable industry in apples and pear growing is being built up.

Jackson and Josephine Counties are noted for their pear production. In no section of the state has the pear been developed to the extent that it has in this region. Bartlett, Howell, Anjou, Bosc, Comice, and Winter Nelis are the principal varieties. In addition to pears a considerable apple acreage is found in the valley, Yellow Newtowns, Spitzenbergs, and Jonathans being the leading varieties. In some sections, such as Merlin and Ashland, peach growing is an industry of importance. A few French prunes and apricots are produced. Small fruit and truck growing is very profitable on the alluvial river bottom lands. The vinifera grapes, such as Muscat, Tokay, and Malaga, succeed in the red hills with sunny exposures. This industry in a number of cases is proving to be very profitable.

FRUIT-SOUTHERN OREGON DIVISION-1910-11.

\begin{tabular}{|c|c|c|c|c|c|c|}
\hline - & Reports. & Acres. & Total Crop. & Per Acre. & $\begin{array}{c}\text { Average } \\
\text { Price. }\end{array}$ & $\begin{array}{l}\text { Income } \\
\text { Per Acre. }\end{array}$ \\
\hline 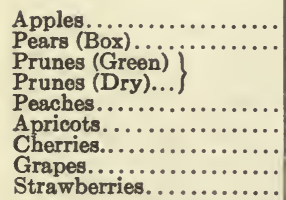 & $\begin{array}{r}73 \\
53 \\
28 \\
43 \\
2 \\
2 \\
7 \\
3 \\
15\end{array}$ & $\begin{array}{r}664 \\
3643 \\
54 \\
342 \\
1,495 \\
2 \\
5 \\
55 \\
173\end{array}$ & $\begin{array}{r}104,112 \text { bxs. } \\
81,961 \text { bxs. } \\
734 \text { bu. } \\
849,300 \text { lbs. } \\
38,851 \text { bxs. } \\
300 \text { bxs. } \\
8,000 \text { lbs. } \\
5,000 \text { crts. } \\
1,395 \text { crts. }\end{array}$ & 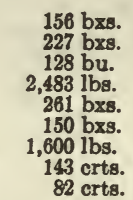 & $\begin{array}{c}\$ 1.48 \\
1.48 \\
.73 \\
.052 \\
.58 \\
1.00 \\
.12 \\
.60 \\
1.72\end{array}$ & $\begin{array}{r}\$ 230.88 \\
335.96 \\
93.44 \\
128.89 \\
156.12 \\
150.00 \\
192.00 \\
85.00 \\
141.04\end{array}$ \\
\hline
\end{tabular}


VEGETABLES-SOUTHERN OREGON DIVISION-1910-11.

\begin{tabular}{|c|c|c|c|c|c|c|}
\hline & Reports. & Acres. & Crop. & Per Acre. & $\begin{array}{c}\text { Average } \\
\text { Price. }\end{array}$ & $\begin{array}{l}\text { Income } \\
\text { Per Acre. }\end{array}$ \\
\hline 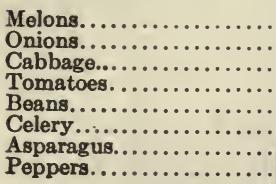 & $\begin{array}{r}16 \\
17 \\
9 \\
14 \\
18 \\
4 \\
1 \\
1\end{array}$ & $\begin{array}{c}57 \frac{1}{2} \\
3 \frac{3}{3} \\
6 \\
6 \\
46 \\
1 \frac{3}{2} \\
. \frac{3}{2} \\
. \frac{1}{4}\end{array}$ & $\begin{array}{c}8,620 \text { crts. } \\
110,700 \text { lbs. } \\
6,200 \text { lbs. } \\
5,400 \text { bxs. } \\
53,500 \text { lbs. } \\
2,300 \mathrm{dz} . \text { bun } \\
1,875 \text { lbs. } \\
50-75 \text { crts. }\end{array}$ & $\begin{array}{c}151 \text { crts. } \\
28,166 \text { lbs. } \\
7,750 \text { lbs. } \\
900 \text { bxs. } \\
1,163 \text { lbs. } \\
1,725 \text { dz.bun } \\
3,750 \text { lbs. } \\
200-250 \text { crts. }\end{array}$ & $\begin{array}{l}\$ 1.67 \\
.018 \\
.015 \\
.38 \\
.048 \\
.70 \\
.08 \\
.60\end{array}$ & $\begin{array}{r}\$ 252.17 \\
506.98 \\
116.25 \\
342.00 \\
55.82 \\
1,207.50 \\
300.00 \\
150.00\end{array}$ \\
\hline
\end{tabular}

The tables of production show the average secured in the survey. It is interesting to note a few specimen cases. While above the average, these show what it is possible to attain where the conditions are ideal and the best of care is given to the orchards.

Orchard No. 19, contained 30 acres of fruit, 25 acres being devoted to apples and 5 acres to pears. The total income in 1910 from this ranch was $\$ 23,528, \$ 22,545$ being from the orchard and garden. The total net profit, deducting expenses, was $\$ 17,813$. This ranch was purchased early in 1910 for $\$ 30,000$. The owner keeps very careful records, and the figures were compiled from his bank books and records.

Orchard No. 48, a small pear orchard, consisting of $7 \frac{1}{2}$ acres, produced $\$ 9,300$ worth of pears in 1910 , which left a net gain of $\$ 5,935$.

This section contains very large orchards as well as many small orchards. One of the largest orchards in the valley is Ranch No. 46 , containing 15 acres of Newtown apples, 10 acres of Ben Davis apples, 9 acres of Jonathan apples, and 119 acres of pears. The total sales from this ranch in 1910 were $\$ 81,946$, which left a net gain of $\$ 44,774$. A 40 acre block of pears on this ranch averaged $\$ 600$ per acre net for ten years from 1901 to 1911 .

\section{Willamette Valley Division.}

This is the largest horticultural division in the state, including ten counties. There is found in this valley a wide range of soil, elevation and climate, and as a result we find its horticulture to be diversified. This valley is the center of the dried prune industry of the state, of the culture of the Loganberry, the onion, the English walnut, and the sweet cherry. In addition large areas are devoted to small fruit production, garden truck, apples, pears, and peaches. Nearly all types of fruit are grown on the alluvial river bottoms, apples and pears on the clay loams, prunes and cherries on the red hills, while many of the table lands are adapted to nearly all types of deciduous fruits.

While there are certain centers of horticultural production in the valley, on the other hand every county produces varieties of all kinds of fruit commercially listed for this region. 
FRUIT-WILLAMETTE VALLEY, DIVISION-1910-11.

\begin{tabular}{|c|c|c|c|c|c|c|}
\hline & Reports. & Acres. & Total Crop. & Per Acre. & $\begin{array}{c}\text { Average } \\
\text { Price. }\end{array}$ & $\begin{array}{l}\text { Income } \\
\text { Per Acre. }\end{array}$ \\
\hline 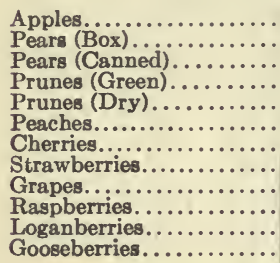 & $\begin{array}{r}176 \\
38 \\
38 \\
130 \\
130 \\
19 \\
77 \\
40 \\
12 \\
39 \\
2 \\
4\end{array}$ & $\begin{array}{r}290 \frac{1}{3} \\
15 \frac{1}{3} \\
35 \\
249 \frac{1}{3} \\
1,428 \\
117 \frac{1}{3} \\
51 \\
63 \frac{3}{4} \\
7 \frac{1}{3} \\
15 \frac{1}{3} \\
83 \frac{1}{2} \\
1\end{array}$ & $\begin{array}{r}56,390 \mathrm{bxs} . \\
3,390 \mathrm{bxs} . \\
55 \mathrm{~T} \text {. } \\
31,249 \mathrm{bu} . \\
3,023,100 \mathrm{lbs} . \\
24,541 \mathrm{bxs} . \\
194,200 \mathrm{lbs} . \\
10,681 \mathrm{crts} . \\
75,440 \mathrm{lbs} . \\
42,625 \mathrm{lbs} . \\
164\} \mathrm{T} . \\
4,700 \mathrm{lbs} .\end{array}$ & $\begin{array}{r}193 \mathrm{bxs} . \\
216 \mathrm{bxs} . \\
1.59 \mathrm{~T} . \\
125 \mathrm{bu} . \\
2,117 \mathrm{lbs} . \\
202.8 \mathrm{bxs} . \\
3,807 \mathrm{lbs} . \\
246 \mathrm{crts} . \\
10,058 \mathrm{lbs} . \\
2,750 \mathrm{lbs} . \\
2 \mathrm{~T} . \\
4,700 \mathrm{lbs} .\end{array}$ & $\begin{array}{c}\$ 0.85 \\
.86 \\
30.31 \\
.92 \\
.064 \\
.76 \\
.039 \\
1.32 \\
.038 \\
.04 \frac{1}{2} \\
82.15 \\
.05\end{array}$ & $\begin{array}{r}\$ 164.05 \\
185.76 \\
48.06 \\
115.00 \\
135.49 \\
154.12 \\
148.47 \\
324.72 \\
382.62 \\
123.75 \\
164.90 \\
235.00\end{array}$ \\
\hline
\end{tabular}

Note:-Loganberry yield is for young patches. Mature patches yield from 4 to 5 tons.

VEGETABLES-WILLAMETTE VALLEY DIVISION-1910-11.

\begin{tabular}{|c|c|c|c|c|c|c|}
\hline & Reports. & Acres. & Total Crop. & Per Acre. & $\begin{array}{c}\text { Average } \\
\text { Price. }\end{array}$ & $\begin{array}{l}\text { Income } \\
\text { Per Acre. }\end{array}$ \\
\hline 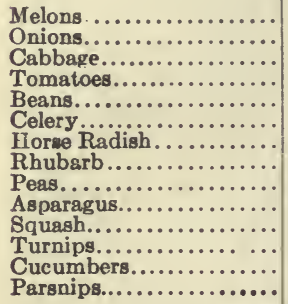 & $\begin{array}{r}2 \\
28 \\
12 \\
8 \\
1 \\
4 \\
1 \\
8 \\
2 \\
8 \\
5 \\
1 \\
3 \\
5\end{array}$ & $\begin{array}{c}4 \\
129 \frac{1}{4} \\
18 \\
3 \\
1 \\
10 \frac{1}{2} \\
16 \\
9 \\
5 \\
3 \\
3 \\
2 \\
2 \\
-\frac{1}{3} \\
\frac{1}{7}\end{array}$ & $\begin{array}{c}23 \mathrm{~T} . \\
38,426 \mathrm{sks} . \\
226 \mathrm{~T} . \\
2,123 \mathrm{bxs} . \\
200 \mathrm{bu} . \\
15,600 \mathrm{dz} . \mathrm{bun} \\
18 \mathrm{~T} . \\
192,000 \mathrm{lbs} . \\
10,000 \mathrm{lbs} . \\
6,350 \mathrm{lbs} . \\
301 \mathrm{~T} . \\
250 \mathrm{sks.} \\
20 \mathrm{bbl} . \\
14,100 \mathrm{lbs} .\end{array}$ & $\begin{array}{c}5 \mathrm{~T} \text { T. } \\
297.3 \mathrm{sks} . \\
12.5 \mathrm{~T} . \\
707.6 \mathrm{bxs} . \\
200 \mathrm{bu} . \\
1,486 \mathrm{dz} . \mathrm{bun} \\
3 \mathrm{~T} . \\
21,333 \mathrm{lbs} . \\
2,000 \mathrm{lbs} . \\
1,953 \mathrm{lbs} . \\
9.37 \mathrm{~T} . \\
125 \mathrm{sks} . \\
40 \mathrm{bbl} . \\
16,114 \mathrm{lbs} .\end{array}$ & $\begin{array}{c}\$ 21.50 \\
1.38 \\
13.66 \\
.50 \\
1.25 \\
.56 \\
140.00 \\
.018 \\
.04 \\
.08 \\
4.69 \\
1.00 \\
6.00 \\
.015\end{array}$ & $\begin{array}{r}\$ 123.62 \\
440.27 \\
170.75 \\
424.50 \\
250.00 \\
832.16 \\
420.00 \\
383.99 \\
80.00 \\
156.24 \\
43.80 \\
125.00 \\
240.00 \\
241.71\end{array}$ \\
\hline
\end{tabular}

The two tables of vegetables and fruits are typical of average conditions as found by the survey. To give an idea, however, of what is being done by some of the growers in this valley, the following figures are interesting:

Farm No. 45, contains 21 acres of apples, peaches and prunes. The income in 1910 from this farm was $\$ 6,900$.

Farm No. 27, contains 20 acres in bearing:-15 acres of apples, 3 acres of prunes, 2 acres of cherries, $-\frac{1}{4}$ acre of Loganberries and 15 pear trees. The income from this fruit for 1910 was $\$ 5,013.75$.

Farm No. 4, contains 37 acres in bearing:-3 acres apples, 21 acres peaches, 5 acres pears, and 7 acres of prunes. The total sales for 1910 were $\$ 14,750$.

Farm No. 1, is a typical large prune farm, containing 123 acres of prunes and 2 acres of cherries in bearing. Total income for 1910 from this orchard was $\$ 20,150$.

While the figures for prunes do not total as high as many fruits, it should be borne in mind that the cost of producing is relatively low.

Farm No. 2, contains 25 acres of Loganberries in full bearing. The total income from berries was $\$ 10,000$ in 1910 . In addition $\$ 3,750$ worth of young plants were sold. The net profit on this farm was $\$ 9,212$. 
Farm No. 56, contains $8 \frac{1}{2}$ acres of onions, from which 2,400 sacks were sold, which brought $\$ 4,200$. The net gain for this farm in 1910 was $\$ 3,363$.

Farm No. 39, contains 5 acres of onions, producing 1,600 sacks which sold for $\$ 2,700$.

Farm No. 57, consists of only 2 acres of celery, and a small patch of cabbage and corn, making a total sales of $\$ 1,550$, leaving a net gain of $\$ 842$.

\section{Columbia Basin Division.}

The Columbia Basin Division includes a number of widely separated fruit districts. These districts are quite dissimilar in many respects, such as climate, soil, and variety adaptability. In the table of incomes this district is shown to give a greater profit per acre than any of the other districts. The reasons for this are, from a horticultural point of view, due to the following conditions: First, the fruit farms are small. Second, they are farmed intensively. Third, the climatic and soil conditions allow for a wide diversity of crops. Fourth, irrigation is used supplementarily very successfully on many of the farms.

The districts included in the Columbia Basin Division are the Freewater Milton district, which is part of the Walla Walla valley. This region produces a wide range of fruits and vegetables. Probably no other region in the state is as diversified in a small area as this district. Prunes for shipping green, peaches, apples, berries, cherries, and garden truck are all grown on a commercial scale.

Irrigation is used quite extensively in this valley.

The Hermiston-Stanfield district is an irrigated district which has been developed in the past few years. Horticulturally it shows promise of producing early vegetables, lima beans, melons, peppers, peaches, table grapes, and Winesap apples.

The Dalles district is primarily a stone fruit district. Prunes, peaches, apricots and Royal Anne cherries are all grown commercially. The vinifera grapes also succeed in this district. In the valleys to the south apples and similar fruits are being produced successfully.

The Hood River and Mosier districts are devoted mostly to apple culture, Spitzenbergs and Yellow Newtowns being the leaders. Some pears and berries, especially strawberries, are also grown.

FRUIT-COLUMBIA BASIN DIVISION-1910-11.

\begin{tabular}{|c|c|c|c|c|c|c|}
\hline & Reports. & Acres. & Total Crop. & Per Acre. & $\begin{array}{c}\text { Average } \\
\text { Price. }\end{array}$ & $\begin{array}{l}\text { Income } \\
\text { Per Acre. }\end{array}$ \\
\hline 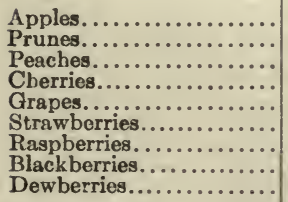 & $\begin{array}{r}58 \\
23 \\
36 \\
22 \\
8 \\
20 \\
2 \\
7 \\
3\end{array}$ & $\begin{array}{l}379 \\
28 \frac{1}{2} \\
95 \\
17 \frac{1}{4} \\
52 \frac{1}{2} \\
41 \\
7^{\frac{1}{2}} \\
4\end{array}$ & $\begin{array}{r}135,204 \text { bxs. } \\
487,500 \mathrm{lbs} . \\
48,851 \mathrm{bxs} . \\
102,410 \mathrm{lbs} . \\
33,360 \mathrm{crts} . \\
4,495 \mathrm{crts} . \\
182 \mathrm{crts} . \\
1,078 \mathrm{crts} . \\
457 \mathrm{crts} .\end{array}$ & $\begin{array}{r}359 \text { bxs. } \\
16,956 \text { lbs. } \\
514 \text { bxs. } \\
5,825 \text { lbs. } \\
635 \text { crts. } \\
109 \text { crts. } \\
364 \text { crts. } \\
168 \text { crts. } \\
114 \text { crts. }\end{array}$ & $\begin{array}{r}\$ 1.16 \\
.01 \frac{1}{3} \\
.738 \\
.04 \frac{8}{.605} \\
2.13 \\
1.95 \\
1.64 \\
2.00\end{array}$ & $\begin{array}{r}\$ 416.44 \\
254.34 \\
379.33 \\
277.97 \\
384.17 \\
232.17 \\
709.80 \\
275.52 \\
228.00\end{array}$ \\
\hline
\end{tabular}


VEGETABLES-COLUMBIA BASIN DIVISION-1910-11.

\begin{tabular}{|c|c|c|c|c|c|c|}
\hline 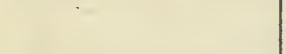 & Reports. & Acres. & Total Crop. & Per Acre. & $\begin{array}{c}\text { Average } \\
\text { Price. }\end{array}$ & $\begin{array}{l}\text { Income } \\
\text { Per Acre. }\end{array}$ \\
\hline 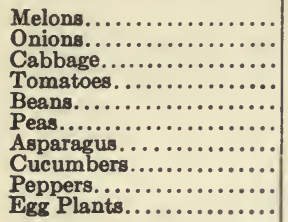 & $\begin{array}{r}2 \\
1 \\
3 \\
6 \\
10 \\
4 \\
4 \\
4 \\
1 \\
2\end{array}$ & $\begin{array}{l}4 \\
1 \\
5 \\
2 \frac{1}{2} \\
7 \\
4 \frac{1}{2} \\
5 \\
\frac{1}{2} \\
\frac{1}{3} \\
.62\end{array}$ & $\begin{array}{l}550 \text { crts. } \\
200 \text { sks. } \\
26 \text { tons. } \\
1,763 \text { bxs. } \\
38,167 \text { lbs. } \\
11,492 \text { los. } \\
496 \text { bxs. } \\
113 \text { crts. } \\
125 \text { bxs. } \\
200 \text { crts. }\end{array}$ & $\begin{array}{r}138 \text { crts. } \\
200 \text { sks. } \\
4.7 \text { tons. } \\
1,175 \text { bxs. } \\
5,452 \text { lbs. } \\
2,508 \text { lbs. } \\
99 \text { bxs. } \\
226 \text { crts. } \\
250 \text { bxs. } \\
322.6 \text { crts. }\end{array}$ & $\begin{array}{r}\$ 1.67 \\
1.60 \\
30.00 \\
.84 \\
.054 \\
.045 \\
.66 \\
.82 \\
.60 \\
1.00\end{array}$ & $\begin{array}{r}\$ 230.46 \\
320.00 \\
141.00 \\
987.00 \\
294.41 \\
112.86 \\
65.34 \\
185.32 \\
150.00 \\
322.60\end{array}$ \\
\hline
\end{tabular}

The tables show average conditions as brought out by the survey. However, one finds exceptional returns in such districts where diversified fruit culture is practiced. As examples of what has been done in these districts by men who have been skillful growers and who have had unexcelled facilities with which to work, the following is interesting.

Farm No. 27, contains 14 acres of large mature apple trees in first class condition. In 1910 this farm produced $\$ 31,364$ worth of apples or approximately $\$ 1,500$ per acre.

Farm No. 16, contains 9 acres of apple trees, which in 1910 produced 4,400 boxes of apples which sold for $\$ 6,223$.

Farm No. 28, contains 7 acres of apples, 3 acres of peaches, and $\frac{1}{2}$ acre of cherries. The total sales from the $10 \frac{1}{2}$ acres was $\$ 8,878.67$. The net gain from all sources on this farm was $\$ 5,121$.

Farm No. 23, contains only 5 acres, consisting of apples, strawberries, blackberries, dewberries, nectarines and plums. The total total sales amounted to $\$ 2,619$ in 1910 .

Farm No. 27, contains $8 \frac{1}{2}$ acres of strawberries, $\frac{1}{4}$ acre of red raspberries, and $\frac{1}{4}$ acre of phenomenal berries. The total sales amounted to $\$ 2,588.50$.

Farm No. 8, contains only 6 acres, being diversified among the following crops:-apples, peaches, prunes, strawberries, black raspberries, blackberries, canteloupes and potatoes. The total sales amounted to $\$ 3,000$.

Farm No. 17, contains 22 acres, consisting of 18 acres of apples, 1 acre of prunes, 2 acres of blackberries, $\frac{1}{2}$ acre of asparagus, and a mixed acreage containing peaches, pears, cherries, crabapples, potatoes, peas and squash. The total sales amounted to $\$ 7,764.42$. The net income from this farm was $\$ 6,183$.

\section{Blue Mountain Division.}

The Blue Mountain Division is found near the eastern border of the state, most of the fruit being grown above the elevation of 2,000 feet. There are a number of quite highly developed horticultural districts in this area. The Grande Ronde Valley is the largest fruit section. A considerable apple industry has been built up in this valley with such varieties as York Imperial, Gano, Rome Beauty, and Jonathan. In the vicinity of Cove, Bing cherries and 
Italian prunes are grown for shipping green to eastern markets. Eagle and Pine valleys in the vicinity of Baker are giving considerable attention to fruit production and in the vicinity of the Snake River a considerable area is to be found upon which almost any type of deciduous fruit can be grown.

FRUIT-BLUE MOUNTAIN DIVISION-1910-11.

\begin{tabular}{|c|c|c|c|c|c|c|}
\hline & Reports. & Acres. & Total Crop. & Per Acre. & $\begin{array}{c}\text { Average } \\
\text { Price. }\end{array}$ & $\begin{array}{l}\text { Income } \\
\text { Per Acre. }\end{array}$ \\
\hline 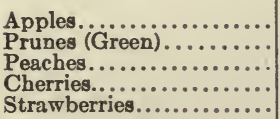 & $\begin{array}{r}23 \\
6 \\
5 \\
10 \\
6\end{array}$ & $\begin{array}{r}323 \frac{1}{2} \\
8 \frac{1}{4} \\
48 \\
17 \frac{3}{4} \\
4 \frac{1}{2}\end{array}$ & $\begin{array}{r}60,984 \text { bxs. } \\
95,523 \text { lbs. } \\
4,500 \text { bxs. } \\
159,000 \text { lbs. } \\
810 \text { crts. }\end{array}$ & $\begin{array}{cc}185 & \text { bxs. } \\
11,578 & \text { lbs. } \\
93.75 & \text { bxs. } \\
8,957 & \text { lbs } \\
180 & \text { crts. }\end{array}$ & $\begin{array}{l}\$ 0.97 \\
.009 \\
.86 \\
.06 \\
2.46\end{array}$ & $\begin{array}{r}\$ 178.89 \\
108.24 \\
80.63 \\
574.64 \\
443.33\end{array}$ \\
\hline
\end{tabular}

The above table has shown the average conditions of this district, but the showing of a few of the better farms is of interest.

Farm No. 42, contains $6 \frac{1}{2}$ acres of apples, $2 \frac{1}{2}$ acres of cherries, and a few scattering trees of prunes and peaches. It produced in 1910 $\$ 4,200$ worth of fruit. $\$ 400$ worth of produce was sold from this farm, leaving a total net gain of $\$ 2,727$.

Farm No. 18, contains 3 acres of strawberries and a few scattered peach and pear trees. The total income amounted to $\$ 1,506$.

Farm No. 8, contains 10 acres of bearing apple trees, 1 acre peaches, 2 acres cherries. Total sales, including poultry, bees, and dairy, amounted to $\$ 7,887.50$, leaving a total net gain of $\$ 5,453$.

\section{Central Oregon Division.}

This division contains a tremendous area of country in which is found a few valleys in which horticultural products are being grown successfully. In those regions which have good soil, ample rainfall or supplementary irrigation, coupled with freedom from frost, horticulture is found to be a very profitable industry. Wherever the canon breezes blow, good locations for fruit can generally be found.

Owing to the lack of transportation facilities in the earlier days this region produced fruit almost entirely for local consumption. While this region as a whole will never become a great horticultural region there are certain portions which can produce horticultural crops very profitably. The Ontario district has nearly the same conditions as are found in the famous Payette district of Idaho, and apples, prunes, melons, and similar crops should be grown in this region in large amounts successfully. The John Day Valley has been producing fruit for many years. One of the largest districts to be found in Central Oregon is near the Goose and Summer Lakes. There is a considerable area of land here of the very congenial soil, and the climatic conditions are favorable for the type of fruits such as apples, pears, peaches, prunes and vegetables, even such types as tomatoes and peppers. With the better transportation facilities which have recently been inaugurated in Eastern Oregon it is only a question of a short time before the favorable districts will develop a horticultural industry of considerable importance. 


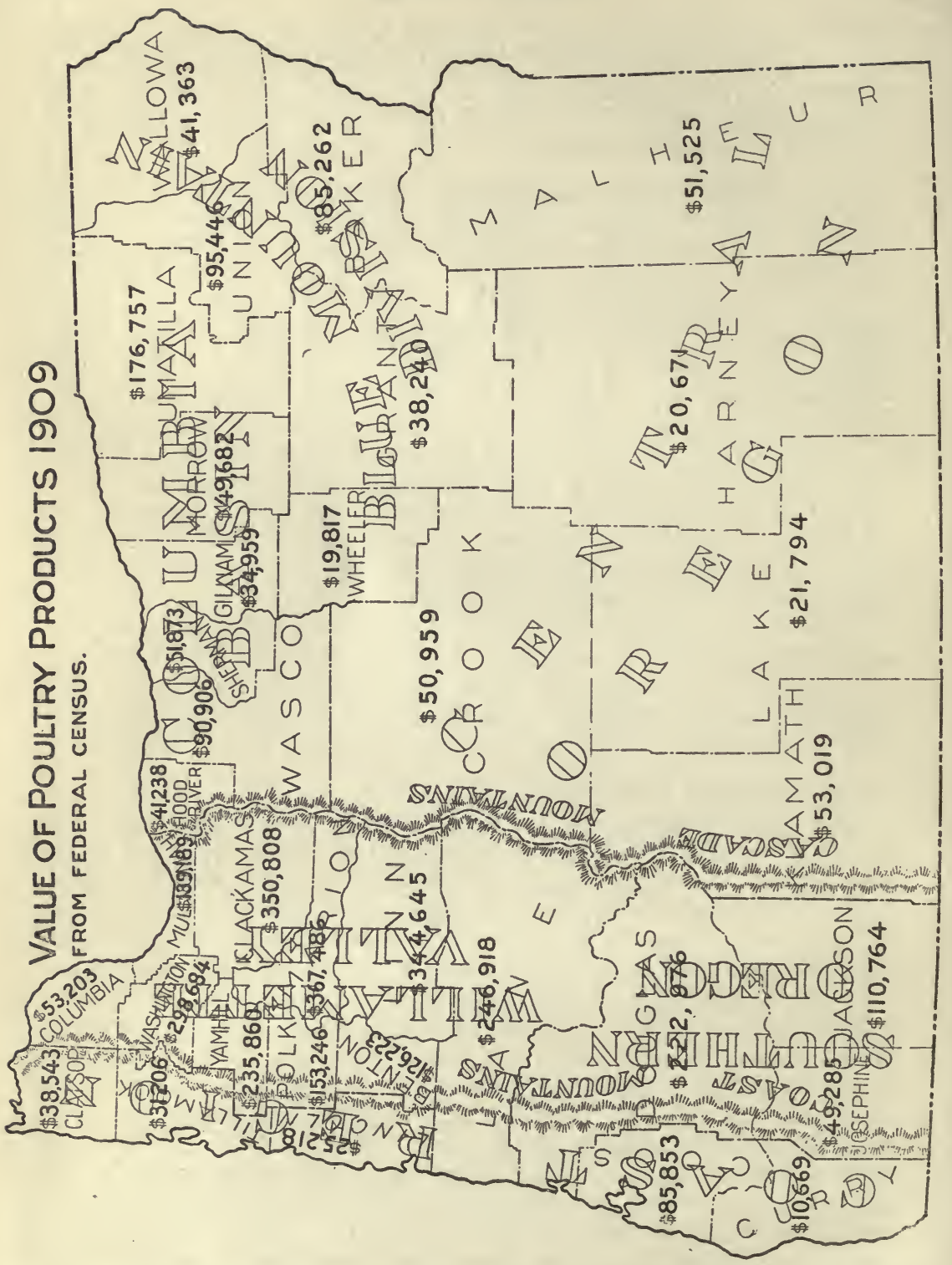

If anything were needed to prove that conditions are favorable in Oregon to the poultry industry it would be found in the ogg records that have been made by laying fowls at the Oregon Experiment Station at Corvallis. During 1912, egg records were secured that exceeded those msde in any other state, in the Union so far as authentic records are concerned. For the fiscal year, ending September 10, 1913, one hen at the Oregon Experiment Station broke the world's record by lajing 291 eggs in twelve months, the previous record being 282. The Oregon hen laid 99 eggs in 100 consecutive days in the Spring. 


\title{
THE POULTRY INDUSTRY IN OREGON.
}

\author{
By JAMES Dryden,
}

Professor of Poultry Husbandry.

\section{SEVEN OREGON FARMS, SHOWING DIFFERENT TYPES OF}

POULTRY KEEPING-1911-12.

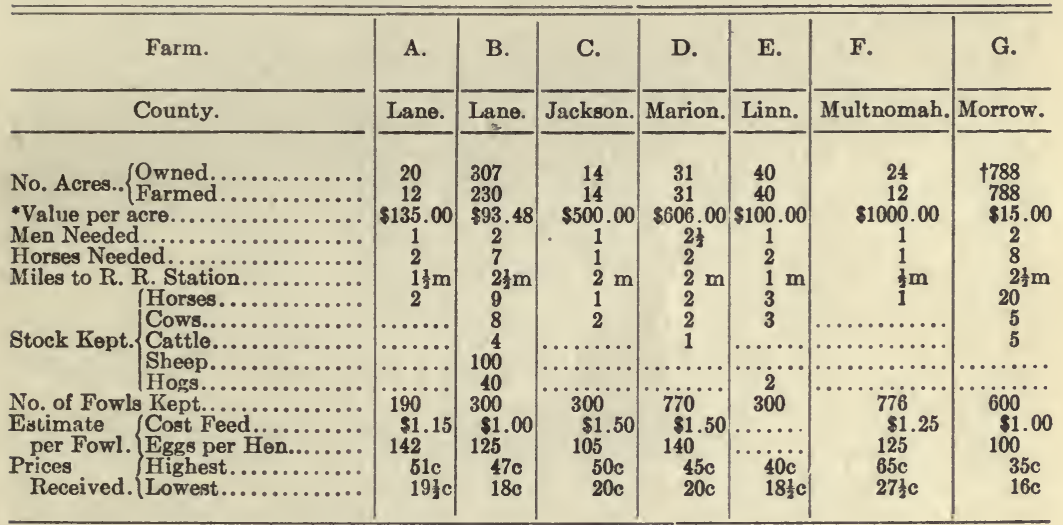

*This value does not include buildings.

tOwns 628 acres, rents 160 acres.

\begin{tabular}{|c|c|c|c|c|c|c|c|c|}
\hline & Farm & A. & B. & C. & D. & E. & F. & G. \\
\hline \multicolumn{2}{|c|}{$\begin{array}{l}\text { Hay and Field Crops. } \\
\text { Animal Husbandry... } \\
\text { Dairy............... } \\
\text { Orchard and Garden. }\end{array}$} & $\begin{array}{r}\$ 64.00 \\
\cdots \cdots \cdots \cdots \\
\cdots \cdots \cdots \cdots \\
\cdots \cdots\end{array}$ & $\begin{array}{r}\$ 1,381.20 \\
996.00 \\
300.00 \\
\ldots \ldots\end{array}$ & $\begin{array}{r}\$ 140.00 \\
1,750.00\end{array}$ & $\begin{array}{r}\$ 10.00 \\
50.00 \\
5,270.00\end{array}$ & $\begin{array}{r}835.00 \\
89.00 \\
3.00\end{array}$ & $\mid \begin{array}{l}\cdots \cdots \cdots \\
\cdots \cdots \cdots \\
\cdots \cdots \cdots \\
\cdots \cdots \cdots \\
\cdots \cdots\end{array}$ & $\begin{array}{r}\$ 555.00 \\
\because 63.00 \\
410.00\end{array}$ \\
\hline \multirow[t]{2}{*}{$\begin{array}{l}\text { Value of } \\
\text { Poultry } \\
\text { Sold. }\end{array}$} & $\left\{\begin{array}{l}\text { Chickens... } \\
\text { Turkeys.... } \\
\text { Ducks..... } \\
\text { Geese...... } \\
\text { Eggs........ }\end{array}\right.$ & $\begin{array}{l}\$ 32.50 \\
\ldots \ldots \\
\ldots \ldots\end{array}$ & $\begin{array}{r}\$ 100.00 \\
\cdots .7 \% 30 \\
15.30 \\
\text { D'ck14.00 } \\
710.00\end{array}$ & $\begin{array}{l}\$ 62.50 \\
\cdots \cdots \\
\cdots \cdots\end{array}$ & $\begin{array}{r}\$ 150.00 \\
\cdots \cdots \cdots \cdots \\
\cdots \cdots \cdots \\
\cdots \cdots \cdots\end{array}$ & $\begin{array}{r}\$ 60.00 \\
\cdots \cdots \cdots \cdots \\
\cdots \cdots \cdots\end{array}$ & $\begin{array}{r}\$ 380.00 \\
\cdots \cdots \cdots \cdots \\
\cdots \cdots \cdots \\
\cdots \cdots \cdots\end{array}$ & $\begin{array}{r}\$ 132.00 \\
400.00 \\
9.00 \\
105.00\end{array}$ \\
\hline & Total....... & $\$ 539.30$ & $\$ 839.30$ & $\$ 902.50$ & $\$ 2,715.00$ & $\$ 917.75$ & $\$ 2,708.00$ & $\$ 1,146.00$ \\
\hline \multicolumn{2}{|c|}{$\begin{array}{l}\text { Labor for others...... } \\
\text { Miscollaneous........ }\end{array}$} & $\begin{array}{r}\$ 50.00 \\
\ldots \ldots \ldots\end{array}$ & $\begin{array}{r}\$ 200.00 \\
50.00\end{array}$ & (n......... & a........... & n.......... & & 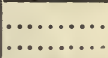 \\
\hline \multicolumn{2}{|c|}{ Total............ } & $\$ 653.30$ & $\$ 3,763.50$ & $\$ 2,792.50$ & $\$ 8,045.30$ & $\$ 1,094.75$ & $\$ 2,708.00$ & $\$ 2,576.00$ \\
\hline \multicolumn{2}{|c|}{$\begin{array}{l}\text { Net Receipts......... } \\
\text { Net Gain.......... } \\
\text { Per Cent Gain on } \\
\text { Investment......... }\end{array}$} & $\begin{array}{r}\$ 413.77 \\
584.77\end{array}$ & $\begin{array}{r}\$ 2,077.00 \\
2,944.00\end{array}$ & $\begin{array}{r}\$ 1,048.50 \\
1,545.50\end{array}$ & $\begin{array}{r}\$ 4,554.30 \\
5,379.30\end{array}$ & $\begin{array}{r}\$ 549.50 \\
-953.50 \\
-\quad 15 \% \\
15.4 \%\end{array}$ & $\begin{array}{r}8520.00 \\
1,420.00\end{array}$ & $\begin{array}{r}\$ 674.00 \\
1,579.00\end{array}$ \\
\hline
\end{tabular}


EXPENSES APRIL 1, 1911 TO APRIL 1, 1912.

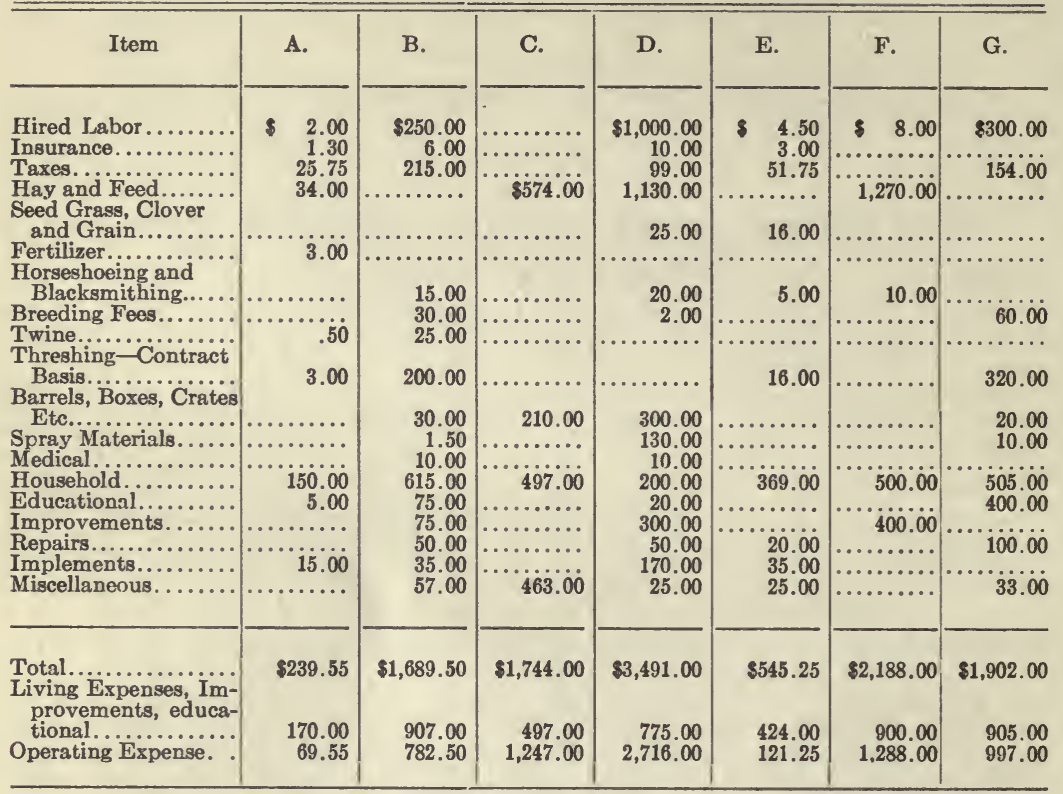

CAPITAL INVESTED.

\begin{tabular}{|c|c|c|c|c|c|c|c|}
\hline Farm & A. & B. & C. & D. & E. & F. & G. \\
\hline 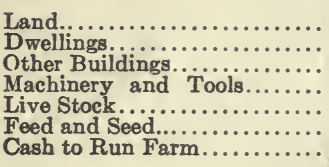 & $\begin{array}{r}\$ 2,700 \\
200 \\
100 \\
75 \\
300 \\
50 \\
200\end{array}$ & $\begin{array}{r}\$ 28,700 \\
1,500 \\
500 \\
200 \\
2,914 \\
100 \\
75\end{array}$ & $\begin{array}{r}\$ 7,000 \\
750 \\
250 \\
200 \\
520 \\
\cdots \cdots\end{array}$ & $\begin{array}{r}\$ 18,800 \\
2,000 \\
4,000 \\
500 \\
485 \\
50 \\
1,000\end{array}$ & $\begin{array}{r}\$ 4,000 \\
800 \\
350 \\
300 \\
460 \\
100 \\
\quad .\end{array}$ & $\begin{array}{r}\$ 24,000 \\
500 \\
800 \\
50 \\
670 \\
100 \\
400\end{array}$ & $\begin{array}{r}\$ 9,420 \\
1,500 \\
500 \\
400 \\
2,315 \\
400 \\
\ldots .\end{array}$ \\
\hline Total .................... & $\$ 3,625$ & $\$ 33,989$ & $\$ 8,720$ & $\$ 26,835$ & $\$ 6,010$ & $\$ 26,520$ & $\$ 14,535$ \\
\hline
\end{tabular}

$\mathfrak{T}$ HE reports of the statistical bureau show that 1,262 interviews were secured from farmers who kept poultry. Interviews were secured in every county of the state. There were reported on the 1,262 farms, 86,220 hens, with an average of 68 per farm. The least number of hens reported on any farm was 6 and the highest number 1,000 . The great majority of the interviews did not furnish enough accurate data to warrant drawing any important lessons. For instance, out of 1,262 farms reporting poultry, only 28 kept any 
actual account of the food consumed. A more or less accurate account of the number of eggs laid was kept by 449 farmers.

Eleven farms reported poultry as a specialty. Nine farms specialized in dairy and poultry. Nine farms specialized in fruit and poultry. Three farms in live stock and poultry. Four in grain growing and poultry. Two in general farming and poultry. Four in truck gardening and poultry. These were some of the farms that showed the most reliable statistics of production. In a great majority of interviews poultry-keeping is reported as a side line to general or mixed farming.

One fact is pretty strongly emphasized in all reports and that is that there is not much actual book-keeping done by the farmer. This is especially true in regard to the cost of feeding the fowls. On 28 farms exact records were kept. The average cost of food per fowl on those 28 farms was $\$ 1.27$ during the year. The figures vary from $\$ 2.00$ per fowl to $\$ 1.00$ as averages for the counties. In most of these cases the food, or a large percentage of it, was bought.

As to the number of eggs laid per fowl the figures at best are estimates. The average during the year on 449 farms was 111.24. To show the unreliability of the average estimates, it is sufficient to state that one farmer reported an average of 36 per fowl, which was the lowest. Another reported an average for his flock of 220 per fowl. It is safe to say that neither of them comes very near the truth. We probably come very near the actual truth, however, by taking the average of the whole 449 . This may show the value of an average though it does not represent the possibilities.

As already explained in another part of this book, it is possible that the reports do not represent the best obtainable data, but there are enough reports of a reliable character when analyzed carefully to indicate something of the status of the poultry industry of this state and of the possibilities in that line of production. It isn't fair to deal with averages in talking about possibilities. If we were to say that the poultry industry was a profitable industry in the United States we would not get very much support for this view from the federal census which deals in averages. According to that report the fowls of the United States average some six dozen eggs per hen. According to the same report the hens of Oregon are doing a little better, but in neither case do the figures represent a profitable industry. We must analyze individual cases if we are to get at the truth of the matter. The average of the 449 farms at the rate of 111 eggs per fowl represents a profitable business, but it dosn't fully represent the possibilities.

The reports show what has generally been known to be a fact, that the poultry industry is not a specialized business. By that I mean that it is not conducted as a separate or exclusive business to any extent. We may have specialists in poultry-keeping, but there should be a wider meaning to the word specialization than is usually given. A man may specialize in poultry-keeping and yet grow other 
crops. He may make poultry-keeping a leading feature of his farming and still conduct a mixed husbandry farm. He may specialize in other branches of agriculture and make poultry-keeping a side issue. In either case there are possibilities for profit. Whatever may be the future of the poultry industry the fact is that it is not a specialized business, so far as regards the production of market poultry and eggs. There are specialists, however, who make a business of raising improved breeding stock. That is a legitimate and necessary business, but the great bulk of poultry produced comes, and probably always will come, from a system of mixed husbandry in which poultry-keeping may be the leading feature or merely a side line to the other farm operations.

A study of the individual reports secured show that we have in Oregon a good poultry state. I have no doubt there are many other poultry producers who have not been interviewed who would give equally good reports, but we have enough, I think, to bring out the point that poultry-keeping is a profitable business here and that there is great encouragement for anyone to embark in that line of farm production if he goes at it in the right way.

\section{SEVEN TYPICAL FARMS.}

I have selected seven different farms located in different sections of the state to show under what conditions poultry is being raised and what results are being secured. They are numbered " $\mathrm{A}$ " to "G" inclusive.

"A" represents a small farm of 20 acres and of one-man power, in fact a bachelor. Practically the only income was from fowls, and the operating expenses, outside of the owner's labor, was little or nothing.

Farm "B" represents a typical mixed husbandry farm of 307 acres. The income was derived from four different branches, namely, field crops, live stock, dairy and poultry, with poultry a prominent feature.

Farm "C" is a small farm of 14 acres showing a combination of peach growing and poultry in a natural fruit district.

Farm "D" is a farm of 31 acres with fruit and poultry as the only two items of production, the orchard producing a diversity of fruits.

Farm "E" shows a different type of poultry farming. Here poultry is the leading feature, with some livestock, dairy and orchard products as subsidiary lines. This shows what may be done on a comparatively small farm in diversified farming with poultry as a specialty.

Farm "F" represents a special poultry farm. In this case poultry is the only business of the owner.

Farm "G" is another, though different, type of mixed husbandry farm, located in the eastern section of the state. In this case there is a large acreage of comparatively cheap land but a system of mixed husbandry prevails, with poultry as the leading feature. 
The statistical data has been summarized in concise form in the tables on pages 86 and 87 . Table A gives general information in regard to the seven farms. It will be noticed that the principal geographical sections of the state are represented in this list of farms. The Willamette Valley is represented by 5 farms, A, B, D, E, and F. Southern Oregon or the Rogue River Valley by "C" and Eastern Oregon by "G." This does not fully cover or represent the whole state so far as climatic conditions are concerned but the data from other sections were not accurate enough or complete enough to warrant extended consideration.

\section{Climatic Conditions.}

These seven farms, however, represent sections of various temperature and moisture conditions. In the Willamette Valley the climate is mild with an average minimum temperature of about 34 degrees above zero. That is, once during the winter, on the average, that temperature is reached. In fact there are but few days in the winter when the freezing temperature occurs. Occasionally a little snow falls but soon melts. The rainfall, however, is considerable in the winter. The winter climate, therefore, may be characterized as mild and humid. The summers are comparatively dry.

Southern Oregon, represented by "C" has a greater range of temperature, some snowfall and occasionally a few days of sleighing. The precipitation is about half that of the Willamette Valley. The altitude ranges at about 2,000 feet.

Eastern Oregon is represented by farm "G". Of course no one point can fully represent the immense territory embraced in this section of the state, but in general this farm will represent the climatic conditions for the larger part of Oregon which lies east of the Cascade range of mountains. The climate in this section is dry, both the rainfall and snowfall being light. It is in the midst of the great wheat and range country where dry farming prevails. For further information in regard to climate see page 67 of this book.

The importance of making the data cover the different sections of the state has been kept in mind. The main purpose, however, in making the selections of farms as they have been made, has been to show the possibilities of poultry farming under different systems of managenemnt.

\section{General Information.}

Table A on Page 86 is largely self-explanatory and the figures are based on reports that I believe to be thoroughly reliable. Other reports could have been given showing more striking results but their reliability or accuracy was not such that it was thought advisable to quote them. This table shows that the number of fowls kept on the different farms range from 190 on farm "A" to 776 on farm " $F$ ". The cost of feed per fowl ranges from $\$ 1.00$ to $\$ 1.50$ per year. The eggs laid per fowl from 100 to 142 . The prices received for the product were the regular market prices, that is, so much a dozen for eggs and 
so much a pound for chickens. There was no special or extra revenue derived from selling breeding stock or eggs and poultry for fancy prices. The highest price received was 65 cents a dozen from farm " $F$ " near Portland. The lowest on the same farm was $27 \frac{1}{2}$ cents. The private trade in this case took the product at a somewhat better price than the general market would pay. The lowest price received on any farm was 16 cents on farm " $G$ " in Eastern Oregon. This farm is 180 miles from Portland. The highest price received on the same farm was 35 cents. It will be noted that the minimum cost of feed was also shown on this farm. There are few sections in the United States, if any, where wheat is cheaper than in the section represented by this farm.

It will be noted that there is a great range in value of land per acre in the different sections. The seven farms are all close to shipping points.

\section{Capital.}

Table D on page 87 gives the estimate as to capital invested in each farm. In figuring the profit on the farm, of course the capital or interest on investment must be taken into account. During the past five years the reports show in most cases, that the land practically doubled in value.

\section{Receipts.}

Table B on page 86 gives the receipts of the different farms for the year April 1, 1911 to April 1, 1912. It is shown that on farm "A", the small place owned and operated by one man, the receipts amounted to $\$ 653$, all but $\$ 114$ being from poultry and eggs.

Farm "B" shows the results from a mixed husbandry farm. The largest item of receipts was from hay and field crops sold; the next from live stock sold; the next from poultry products, and the next dairy products. The total receipts from the farm were $\$ 3,766.50$.

Farm "C", a fruit and poultry farm shows receipts of $\$ 2,792.50$. The crop of peaches selling for $\$ 1,750$; poultry and eggs for $\$ 902.50$ and butter fat $\$ 140.00$.

Farm " $D$ " shows receipts of $\$ 10$ animal husbandry; $\$ 50$ dairy; $\$ 2,715$ poultry and $\$ 5,270$ fruit.

Farm "E" shows some mixed husbandry but the large item of receipts is from poultry, a total of $\$ 917.75$ for poultry and eggs and $\$ 177$ from other sources.

Farm "F" as a special poultry farm shows no other receipts than poultry, the total being $\$ 2,708$.

Farm "G" shows a wide variety of products, poultry being the leading feature, the receipts being $\$ 1,146$ for poultry; $\$ 555$ from field crops; $\$ 465$ from butter and $\$ 410$ from orchard and garden.

\section{Expenses.}

The expenses paid out on the several farms for the year 1911 are shown in table $\mathbf{C}$ on page 87 . It will be noted that there is little 
hired labor employed on any of the farms except "D", there being practically none on A, C, E, and F. On three of the farms money was paid out for feed. Most of the feed used on those farms was purchased, though a small quantity was raised, chiefly green food. On the other four farms no money was paid out for feed, the farm producing all that was fed. The table includes the amount paid out for household expenses. This amount varies in proportion to the size of family and other items. It is interesting to note that the household expenses on farm " $\mathrm{A}$ " were only $\$ 150$. In this case the owner was the only person on the farm. In addition to doing all the farm work he performed all the necessary duties of the household.

Farm "E" supported two persons, and the outlay was $\$ 369$. The household expenses do not include the amount of food produced on the farm such as garden truck, milk, etc. The money paid out on farms " $\mathrm{A}$ " and "E" show just how little a farmer has to purchase or bring onto the farm under certain conditions of diversification.

The total expenses on farm "A" were $\$ 239.55$, the total for farm "E" \$545.25. The total paid out for operating expenses for farm "A" was only $\$ 69.55$ and farm " $\mathrm{E}$ " $\$ 121.25$, showing that those two farms came very nearly being self-sustaining.

The table shows the net operating expenses after deducting the living expenses, improvements, and educational.

As to the profit on different farms, it is difficult to figure this out closely. The figures, however, are complete enough to get a general approximation. On farm " $\mathrm{A}$ " with a total capital of $\$ 3,625$ there was a profit, in other words a net gain, of $\$ 584.77$. This profit is arrived at by subtracting the operating expenses from the total receipts. If we include the living expenses, improvements and educational, there would be a net gain of $\$ 413.77$. In other words, after including everything paid out of whatever nature, the owner had $\$ 413.77$ to deposit in the bank, or to pay interest on investment.

Figuring in the same way farmer "B", with a capital of $\$ 33,989$ made a total net gain of $\$ 2,944$, or $\$ 2,077$ after deducting living expenses, etc.

Farmer "C" with a capital of $\$ 8,720$ shows $\$ 1,048.50$ gain after paying all operating expenses, household, improvements, etc.

Farmer "D" with a capital of $\$ 26,835$ is shown to have in cash $\$ 4,554.30$ after paying all operating expenses including household and improvements.

Farmer "E" with a capital of $\$ 6,010$ showed cash on hand at the end of the year of $\$ 549.50$ after paying all expenses of the farm and household for the year.

Farmer " $F$ " with a capital of $\$ 26,520$ showed net receipts or cash on hand of $\$ 520$.

Farmer " $G$ " with a capital of $\$ 14,535$ showed a cash gain of $\$ 674$, after paying all farm and living expenses. The per cent gain given in each case, shown at the bottom of table, is figured on the basis 
of total net gain. That is, the improvements and living expenses are included in the net gain.

In spite of a heavy valuation in some cases a very satisfactory showing is made on practically all of the farms. It is true that farmer " $\mathrm{F}$ " on the showing made would be money in the pocket if he could sell his place at the estimated capital and invest the money at interest. He shows good returns from the flock which he keeps, but his account shows that his capital investment is too high. The land is valued at $\$ 1,000$ an acre and to make interest on that valuation he must get a considerably larger revenue from his farm. But it shows what may be done on an acreage of that extent. It isn't necessary to invest so much money in land for poultry.

Farmer "G" with 788 acres has $\$ 12,000$ less investment than farmer " $F$ " on twelve acres, the difference being in the value of land. Farmer "G" with no pretence of running a special poultry farm is getting a larger net revenue from his farm than farmer " $F$ ". It might of course be possible for farmer " $F$ " to increase his flock to such an extent so that he could produce on the same acreage double the quantity of poultry and eggs shown in this table. So could farmer "G" produce double the quantity, and he could do it at very much less cost.

Farmer "E" on land valued at $\$ 100$ an acre is making very satisfactory returns on 40 acres. He did it in a modest way, caring for only 300 fowls, enough with a little live stock, to use up all the grain produced on the place. To increase his returns it would only be necessary to increase his flock and to grow more food on the farm, and on the right kind of land 40 acres could produce much more feed and more fowls.

The returns from farms "E" and "F" show a great margin for profit and loss, the net receipts being the same in each case, though there was over four times the amount of capital in one than the other.

Farm "E" shows something of the possibilities of practical poultrykeeping. This is a medium sized farm of 40 acres where poultry is the principal or practically the only source of revenue and where the food is all produced on the land. Farm "A" is also worthy of study in the same connection.

It is well known that the great bulk of poultry products is produced on general farms where poultry keeping is a part of a system of mixed husbandry.

The results from farm " $\mathrm{B}$ " indicate the possibilities of profit where the general farmer gives considerable attention to poultry-keeping without making it the leading feature of the farm. The average farm in Oregon has about 50 fowls. Farmer "B" kept 300 fowls and the returns from the 300 were nearly equal to the returns from field crops or live stock, and it would be an interesting point to learn the comparative value of the poultry compared with the other branches when their returns were figured up at the end of the year. On a farm of 300 acres where grain crops were raised and milk was pro- 
duced there would be little additional cost in keeping 300 fowls in place of 50, so that the profit in the poultry branch of the farm will be comparatively high.

\section{Poultry and Fruit.}

While some fruit was raised on the other farms no specialty was made of fruit raising. Farms "C" and "D" show what can be done where specialties are made of both fruit growing and poultry. In the case of farm "C", peach growing and poultry raising were both specialties, though the peaches were the principal source of revenue in 1911 , there being $\$ 1,750$ receipts from the peaches and $\$ 902.50$ from the poultry. The fowls were allowed to run in the orchard. Here we have a case of a double use of land, and the experience of this farmer fully justifies the practice of combining, under proper conditions, these two industries. Of the 14 acres, 12 are in peaches and the orchard is 16 years old. The owner says: "Lower half of orchard apparently greatly benefited by poultry, which have the run of it. Marked difference in color of foliage, length of new growth and size of fruit. Foliage darker green. New wood growth two-thirds times as much and fruit one-fourth larger." He says that he had a very good year for peaches in 1911. Another significant note is: "Most profitable crop, peaches; surest crop, eggs."

Farm " $D$ " is another poultry and fruit combination. This farm shows very satisfactory returns for the year in question. On 31 acres, with the labor of two regular men and another man half time, there were produced in poultry products and fruit a total of $\$ 8,045.30$. Deducting the operating expenses there was a total profit of $\$ 5,479.30$, without taking into account interest on investment. Deducting the living expenses and improvements there is a net cash gain of $\$ 4,554.30$. Of the total receipts, poultry and eggs furnished $\$ 2,715$. The number of laying hens was 770. There is a variety of fruit produced, but the largest single item is apples. The 31 acres are practically all in fruit of some kind. In addition to apples there is a considerable orchard of prunes and several acres of berry bushes, chiefly raspberries and Loganberries. All the green food for the chickens is produced on the place, a patch of kale being grown and vetch sometimes grown among the trees. This farm shows good management and care. The fowls are kept in colony houses and they have the range of the orchard, no fences being used except during the breeding season when some of the best of the flock are yarded for producing eggs for hatching. The colony houses have not been moved since they were built. The result of this has been that the berry bushes close to the houses show more vigorous growth and produce better than those at the other end of the patch where the chickens seldom range.

The sales from the fruit were nearly double those from the poultry. The following year, however, on account largely of a difference in the market for fruit, the receipts from the poultry exceeded those from the orchard. At the present time Mr. Jorgenson, the owner of this farm, has over a thousand laying hens on the place. 
No attempt has been made to produce fancy breeding stock and the amount received from the poultry was made wholly by selling the product at market prices, the price for eggs ranging from 45 cents a dozen to 20 cents. About $\$ 1,100$ worth of feed was purchased for the fowls so that the profit on the feed purchased was over $\$ 2.00$ per fowl. The exact figures of food cost cannot be given because a small quantity of feed was produced on the place. The owner's estimate is $\$ 1.50$.

The value of the poultry and eggs produced in Oregon in 1912 amounted to about $\$ 7,250,000$ which exceeded the values for fruit, oats, barley, potatoes, wool, or hops. In spite of this there were large importations of eggs from eastern states or from middle west states. In 1911 there were over 200 carloads of eggs shipped into Oregon. There has been great development of the poultry industry during the past few years, and it is estimated that the production now is between three and four million dollars greater than it was five or six years ago. Notwithstanding this great increase in production the prices remain about the same. In a few years there is no reason why Oregon should not produce $\$ 20,000,000$ worth of poultry and eggs a year, and it is doubtful, owing to the great increase of population on the Coast, whether with this increased production there would be much, if any, decrease in the prices received by the producers.

As has been explained in another part of this book, Oregon is a large state in area and the climatic conditions are varied. In fact most any kind of climate outside of a tropical climate may be found in Oregon. Table A on page 86 shows that the Willamette Valley produces a large proportion of the poultry and eggs in this state. This shows that this valley, with its mild, though rainy winters, is a good poultry section. It may not necessarily mean that the Willamette Valley is the best poultry district in the state. It is the oldest section of the state and being near to the Portland markets naturally the greatest development has taken place here. There are other valleys or sections in the state, I believe, that are equally adapted for profitable poultry-keeping.

To show something of the possibilities in egg production in Oregon I may mention that at the Oregon Experiment Station some of the highest egg yields in the United States have been secured. There is a regularly organized Poultry Department at the Agricultural College and I believe it has been fully demonstrated that Oregon is as good as any other state as a poultry section. Egg records as high as 259 in one year and 462 in the first two years of laying have been secured. The College is endeavoring to help the poultry-keepers of the state in various ways. It is furnishing farmers and poultry raisers breeding stock and eggs from fowls that have been bred from heavy producers for several generations. In another way it is helping the producers by publishing and distributing poultry bulletins dealing with different branches of the industry. Anyone wishing further information in regard to methods of poultry-keeping in this state should write to the Poultry Department of the Agricultural College and copies of these bulletins will be sent free on request. 


\section{BEE CULTURE IN OREGON.}

By H. F. Wilson,

Research Assistant in Entomology.

ชִ ITH such data as we have at hand, it would be impossible to estimate correctly the status of bee-keeping in Oregon. Many farmers keep from one to several stands for home use, and in all parts of the state one may find from a few to many colonies that not only furnish honey for the home but also give a market surplus.

In looking over the data secured in this survey, one might be led to infer that most of our honey is produced in Southern Oregon, but that inference is misleading. The division known as Central Oregon probably has the greater number of large commercial apiaries, with the Columbia Basin second and Southern Oregon third. These facts are not shown in the survey, for the reason that it was taken as a general farm survey, and of the five or six commercial apiaries in Southern Oregon, the largest happened to be recorded. In the survey of Central Oregon it so happened that out of a dozen or more commercial apiaries, only two, of medium size, were recorded. With these exceptions, other data at hand show that the average that was arrived at, is fairly representative of existing conditions According to the data in the accompanying table, 402 farms reported bees; a total of 1,637 farms were visited, so that on an average, one farm out of every four has bees.

C. The U. S. Census for 191.0 reports one farm in every five as having bees, but during the last two years the number of colonies has increased, both in the number of large apiaries and in the number on small farms. A considerable increase is due to the number secured by orchardists for pollenization purposes.

With data on hand and the figures from the U. S. Census Report for 1910 , a distribution map has been made which shows some very interesting facts. Each figure represents 1,000 colonies, showing an approximate total of 50,000 colonies with a value of $\$ 250,000.00$. The writer believes that with the present average prices, an average of five dollars per colony is not too high, although the census report gives the total valuation of 47,285 colonies at $\$ 150,164.00$.

Of the 50,000 colonies, less than 20,000 are found outside of the Willamette Valley and Coast Divisions. Apparently then, the honey industry is in Western Oregon, but in reality only about onehalf as much honey is produced in these two divisions as in the others. Many of the bees in the first two sections are barely self-supporting and their only value is in pollenizing the fruit blossoms. The surplus gained from the more thrifty colonies is generally small. The large number in these sections is due to the number of small farms with from one to thirty colonies.

Taking the state as a whole, individual apiaries produce from a few pounds to a carload (figured at about 40,000 pounds). The number of colonies owned by individual bee-keepers varies from a few, to six or seven hundred. 


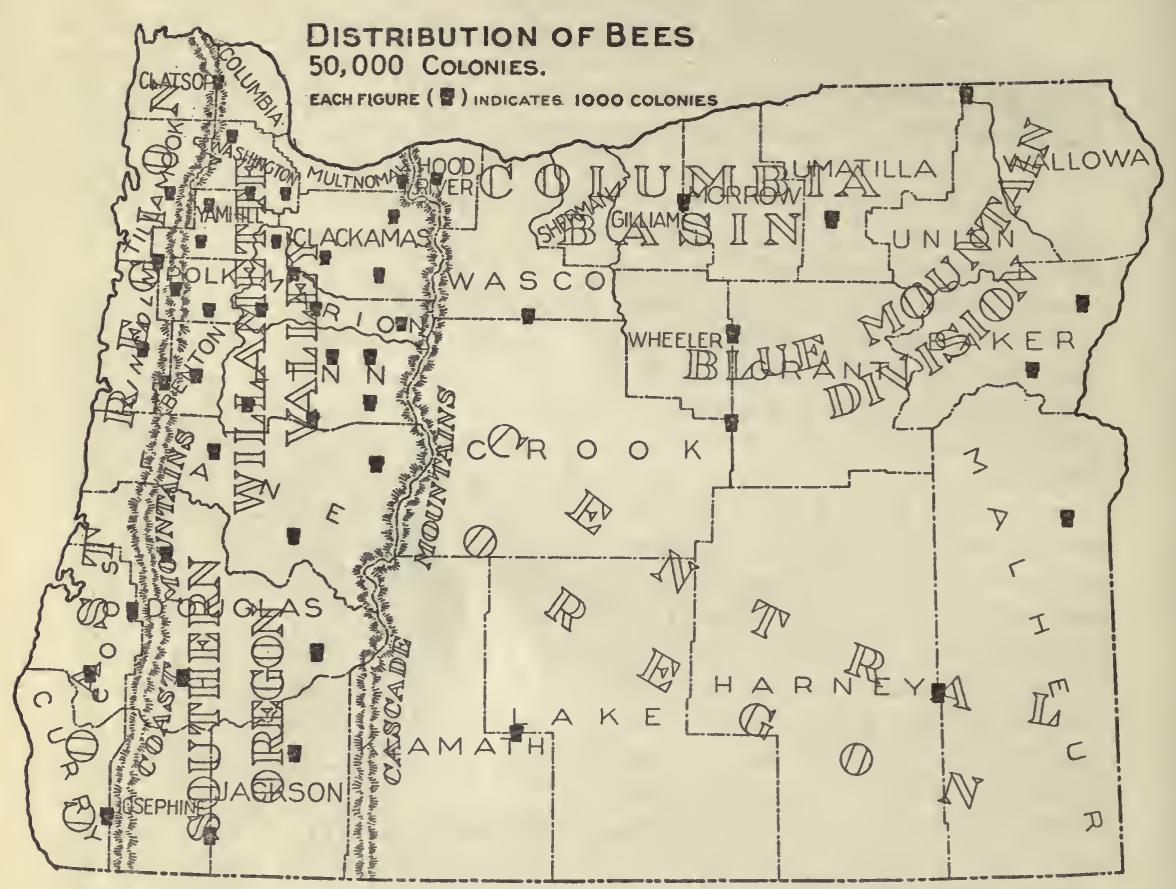

In addition to the honey producing apiaries, there are situated at different points in the state, queen and bee-rearing apiaries.

Discussing each region separately, we find that, in the coast division, some of the finest honey produced anywhere is secured from wild plants such as vine maple (Acer Circinatum), and a plant known as firewood (Epilobium spicatum). No large apiaries are found in this section and the average surplus is small. Section honey only is produced and only a small amount reaches outside markets, as the local demand is greater than the supply. In this section climatic conditions regulate to a great extent the amount of honey produced. Continued rains in the spring, during the blossoming period of fruit trees and other plants, often result in a decreased surplus.

In the Willamette Valley section, conditions are extremely variable. In the valley proper there are no commercial apiaries of any size, and in bad years many bees starve in the fall for lack of stores. Several men in this section have found that it is more desirable to produce extracted honey, as the bees seem to gather more honey in this way under adverse conditions. Alfalfa cannot be grown with success, 
and since there are not many flowering plants to be found after July first, except back in the hills, the surplus must be gathered in the spring. Continued spring rains are also a factor here and oftentimes the blossoming period of the principal honey-producing plants passes without the bees being able to spend more than a few days in gathering honey. Getting back onto the slopes of the Coast Range and the Cascade Mountains, more favorable conditions are found and a fair surplus can usually be secured from the more variable honey-producing plants in the later blooming season.

The division known as Southern Oregon, and comprising only three counties, is different from the other sections of the state in that the region, while not arid, does not have as much rain as the Willamette Valley and Coast divisions. In addition to several wild honey plants, which grow abundantly in this section, alfalfa is grown successfully and fruit bloom offers a fine pasturage while it lasts.

The other three divisions, Central Oregon, the Blue Mountain District, and Columbia Basin, have conditions which are practically the same so far as bee-keeping is concerned. That the bee-keeping industry of these sections is in its infancy can hardly be doubted by one taking a trip through those sections where alfalfa can be grown successfully. Here is also found a vast territory which at present is in sage brush, but may some day be planted to alfalfa, when it will give increased area for bee pasturage. In the vicinity of Ontario and Vale, a large alfalfa district, one can find some of the state's largest"and most productive apiaries. Much of the alfalfa is grown for seed, and with the sweet clover which grows in waste places gives an ideal pasturage for bees. There are many fine apiary locations in different sections of the state, but all of these should be thoroughly investigated before an attempt is made to start an apiary in any one of them.

STATISTICS ON BEE CULTURE.

Based on 402 Reports.

\begin{tabular}{|c|c|c|c|c|c|c|c|c|c|}
\hline \multirow{2}{*}{ Division. } & \multirow{2}{*}{ 要 } & \multirow{2}{*}{ 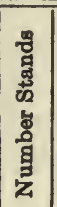 } & \multicolumn{2}{|c|}{$\begin{array}{l}\text { Beekeeping } \\
\text { Successful. }\end{array}$} & \multicolumn{2}{|c|}{$\begin{array}{c}\text { Colonies } \\
\text { Profitable. }\end{array}$} & \multicolumn{2}{|c|}{$\begin{array}{l}\text { Average Price } \\
\text { of Honey. }\end{array}$} & \multirow{2}{*}{$\begin{array}{l}\text { Total } \\
\text { Sales. }\end{array}$} \\
\hline & & & Yes. & No. & Yes. & No. & Comb. & Ex'ctd. & \\
\hline 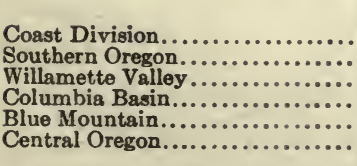 & \begin{tabular}{r|}
75 \\
70 \\
158 \\
47 \\
19 \\
33
\end{tabular} & $\begin{array}{l}570 \\
962 \\
833 \\
994 \\
407 \\
839\end{array}$ & $\begin{array}{r}67 \\
55 \\
123 \\
44 \\
17 \\
33\end{array}$ & $\begin{array}{r}8 \\
15 \\
35 \\
3 \\
2 \\
2 \\
\cdots\end{array}$ & $\begin{array}{l}472 \\
829 \\
657 \\
987 \\
370 \\
839\end{array}$ & $\begin{array}{r}90 \\
133 \\
176 \\
7 \\
37 \\
\cdots\end{array}$ & $\left|\begin{array}{l}\text { Per lob. } \\
12,-20 c \\
123-20 c \\
12-20 c \\
123-20 c \\
12,-15 c \\
12\}-15 c\end{array}\right|$ & $\mid \begin{array}{l}\text { Per } 1 \mathrm{~b} . \\
7 \text { to } 15 \mathrm{c} \\
7 \text { to } 15 \mathrm{c} \\
7 \text { to } 15 \mathrm{c} \\
7 \text { to } 10 \mathrm{c} \\
7 \text { to } 10 \mathrm{c} \\
7 \text { to } 10 \mathrm{c}\end{array}$ & $\begin{array}{l}\mathbf{5} 570.50 \\
2,977.75 \\
679.45 \\
2,367.50 \\
1,009.50 \\
1,605.00\end{array}$ \\
\hline State $\ldots \ldots \ldots \ldots \ldots \ldots$ & 402 & 4605 & 339 & 63 & 4154 & 451 & $\mid 12\}-20 c \mid$ & 7 to $15 c$ & $\$ 9,209.70$ \\
\hline
\end{tabular}



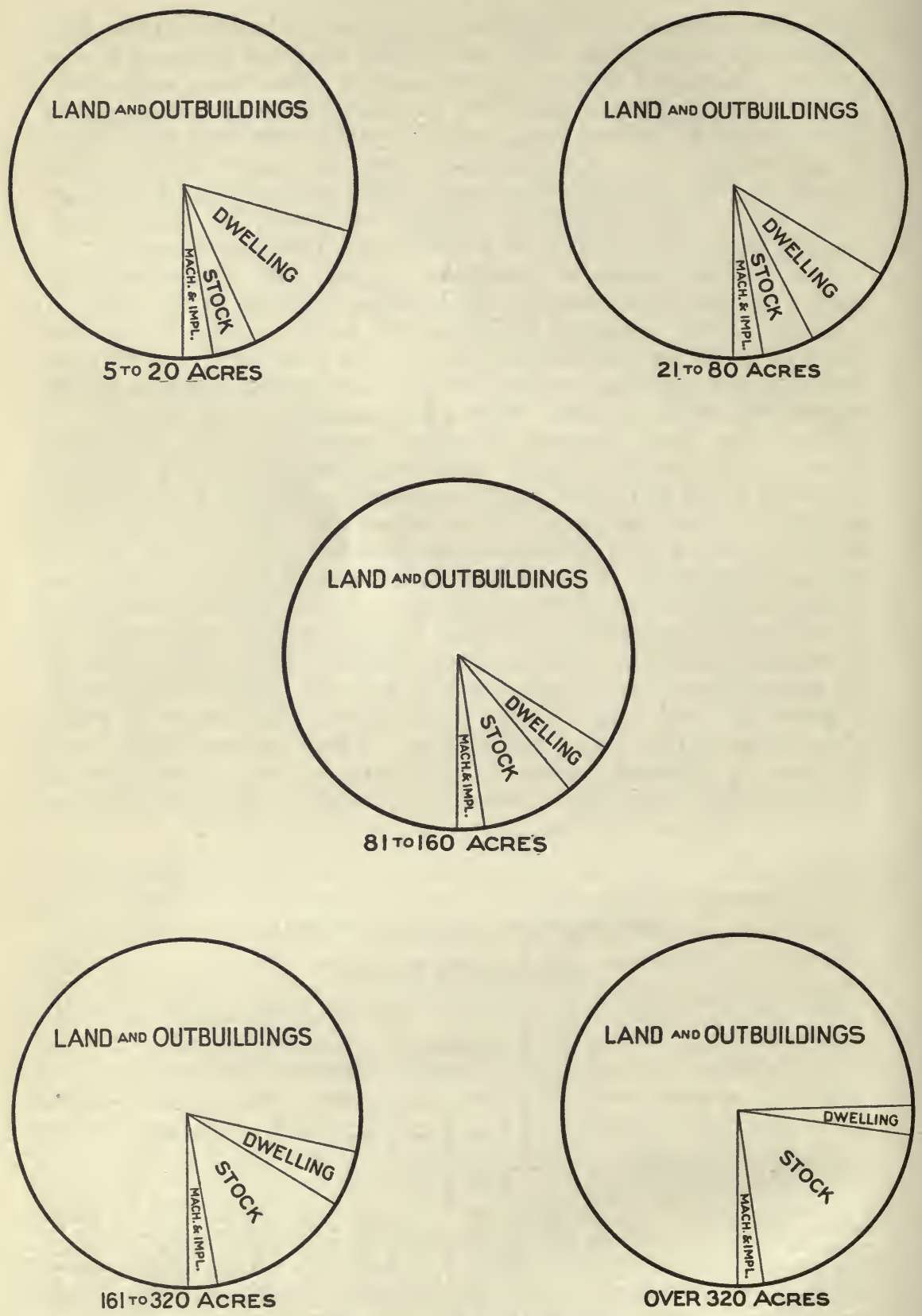

Percentages of Investment. 


\title{
FARM FINANCE.
}

\author{
By J. A. Bexell
}

Dean School of Commerce.

29.

HAT can I do in Oregon with a given capital? How much is required to stock a farm in a given county? What income can be expected on a given investment in a given locality?

These are questions of first importance to the prospective settler. In this survey an attempt was made to find accurate answers to these and many other questions regarding farm finance. The results are found on pages 99 to 106 . It should be remembered that all the tables of results which follow are from the reports of average farmers with average experience of about 12 years in their respective localities. As explained on page 5, the aim of the survey was to secure reports from farmers in average circumstances, and working under average conditions in order that the results might show, not only what can be done, but what are usual results on Oregon farms.

AVERAGE ACREAGE 1911-12.

\begin{tabular}{|c|c|c|c|c|c|c|c|c|c|c|}
\hline Division. & 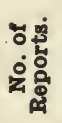 & 路 & 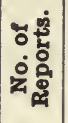 & 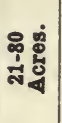 & 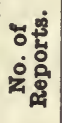 & 递 & 농 & 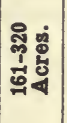 & \%ั & 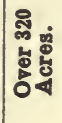 \\
\hline 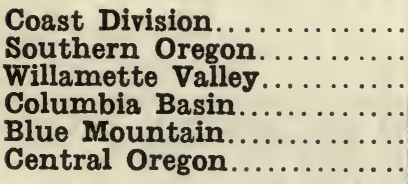 & $\begin{array}{r}3 \\
36 \\
35 \\
26 \\
10 \\
3\end{array}$ & $\begin{array}{l}20 \\
11 \\
15 \\
13 \\
12 \\
13\end{array}$ & $\begin{array}{r}25 \\
57 \\
151 \\
37 \\
10 \\
15\end{array}$ & $\begin{array}{l}61 \\
51 \\
52 \\
45 \\
39 \\
67\end{array}$ & $\begin{array}{r}56 \\
44 \\
135 \\
28 \\
15 \\
39\end{array}$ & $\begin{array}{l}134 \\
133 \\
120 \\
140 \\
141 \\
146\end{array}$ & \begin{tabular}{r|}
54 \\
46 \\
129 \\
22 \\
35 \\
47
\end{tabular} & $\begin{array}{l}245 \\
235 \\
241 \\
255 \\
225 \\
278\end{array}$ & \begin{tabular}{r|}
34 \\
42 \\
100 \\
146 \\
116 \\
94
\end{tabular} & $\begin{array}{r}602 \\
812 \\
549 \\
2137 \\
2327 \\
1343\end{array}$ \\
\hline State.. & 113 & 13 & 295 & 52 & 317 & 131 & 333 & 248 & 532 & 1538 \\
\hline
\end{tabular}

\section{Average Acreage of Farms Reporting.}

In tabulating the financial data, the farms were divided into five groups, as follows: $5-20$ acres, 21 to 80 acres, 81 to 160 acres, 161 to 320 acres, and over 321 acres. All the land owned is included in the averages. The average acreage in each group is shown in the above table and it should be remembered, in reading the several financial tables, that the results are based on the average acreage given under each division. Thus the Coast Division averages are based on 13, 52, 131, 248 and 1,537 acre farms. The common claim that the small farm is the most profitable is borne out by the table on page 104 . 
AVERAGE VALUG OF DWELIING 1911-1912.

\begin{tabular}{|c|c|c|c|c|c|c|c|c|c|c|}
\hline Division. & 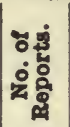 & ఫึ: & 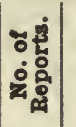 & ఫొ & 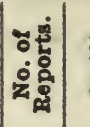 & 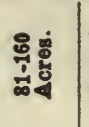 & 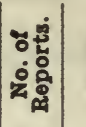 & 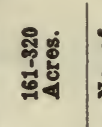 & 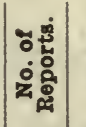 & 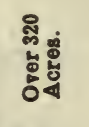 \\
\hline $\begin{array}{l}\text { Coast Division..... } \\
\text { Southern Oregon. } \\
\text { Willamette Valley. } \\
\text { Columbia Basin.. } \\
\text { Blue Mountains. } \\
\text { Central Oregon... }\end{array}$ & $\begin{array}{r}3 \\
32 \\
35 \\
23 \\
10 \\
3\end{array}$ & $\begin{array}{r}700 \\
1247 \\
1149 \\
1331 \\
1320 \\
633\end{array}$ & $\begin{array}{r}25 \\
56 \\
155 \\
33 \\
9 \\
14\end{array}$ & $\begin{array}{r}994 \\
1177 \\
1216 \\
2096 \\
1037 \\
691\end{array}$ & $\begin{array}{r}54 \\
44 \\
130 \\
28 \\
11 \\
37\end{array}$ & $\begin{array}{r}1289 \\
1724 \\
1076 \\
1183 \\
1073 \\
629\end{array}$ & $\begin{array}{r}50 \\
45 \\
123 \\
22 \\
30 \\
45\end{array}$ & $\begin{array}{r}\$ 1038 \\
1666 \\
1509 \\
1046 \\
1472 \\
589\end{array}$ & $\begin{array}{r}33 \\
42 \\
99 \\
143 \\
96 \\
87\end{array}$ & $\begin{array}{r}\$ 1123 \\
1659 \\
1754 \\
1461 \\
1804 \\
1289\end{array}$ \\
\hline State.. & 106 & $\$ 1204$ & 282 & $\$ 1303$ & 304 & 1176 & $315 \$$ & $\$ 1240$ & $500 \$$ & $\$ 1549$ \\
\hline
\end{tabular}

\section{Average Value of Dwelling.}

The average value of the dwelling in different parts of the state is of interest chiefly because it indicates largely the state of develcpment in the different sections, and also what will probably be required of the prospective settler in the different localities. In the state averages, it does not appear that the size of the farm has much effect on the value of the dwelling, the average being $\$ 1,204, \$ 1,303, \$ 1,176$, $\$ 1,240$, and $\$ 1,549$ in the different sizes of farms. The variation is considerable in the various divisions of the state, ranging from $\$ 533$ in Central Oregon to $\$ 2,096$ in the Columbia Basin.

AVERAGE VAIUE OF IIVG STOCK 1911-12.

\begin{tabular}{|c|c|c|c|c|c|c|c|c|c|c|}
\hline Division. & 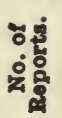 & 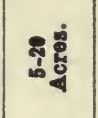 & 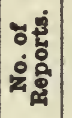 & ণิ & 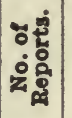 & 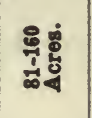 & 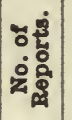 & 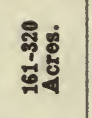 & 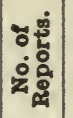 & 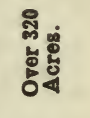 \\
\hline $\begin{array}{l}\text { Coast Division. ... } \\
\text { Southern Oregon. } \\
\text { Willamette Valley. } \\
\text { Columbia Basin.. } \\
\text { Blue Mountain. . } \\
\text { Central Oregon. . }\end{array}$ & $\begin{array}{r}3 \\
26 \\
35 \\
35 \\
\cdots 3\end{array}$ & \begin{tabular}{|r|}
$\$$ \\
771 \\
271 \\
400 \\
298 \\
$\cdots 333$
\end{tabular} & $\begin{array}{r}35 \\
56 \\
138 \\
45 \\
14 \\
14\end{array}$ & $\begin{array}{r}\$ 1369 \\
747 \\
863 \\
697 \\
76 \ddot{6} \\
79\end{array}$ & $\begin{array}{r}66 \\
43 \\
121 \\
32 \\
10 \\
38\end{array}$ & $\begin{array}{r}\$ 2187 \\
1594 \\
1597 \\
1603 \\
4591 \\
2152\end{array}$ & $\begin{array}{r}62 \\
45 \\
112 \\
30 \\
26 \\
47\end{array}$ & $\begin{array}{r}\$ 2281 \\
1958 \\
2195 \\
1637 \\
2888 \\
2675\end{array}$ & $\begin{array}{r}44 \\
40 \\
90 \\
158 \\
94 \\
90\end{array}$ & $\begin{array}{r}\$ 4141 \\
3039 \\
3699 \\
6551 \\
14007 \\
12836\end{array}$ \\
\hline State.. & 102 & $\$ 341$ & 288 & 878 & 310 & $\$ 1887$ & 322 & $\$ 2255$ & 516 & $\$ 8030$ \\
\hline
\end{tabular}

Value of Live Stock.

The live stock industry is one of the most important in Oregon. Its general aspects are fully discussed by Professor Potter on page 15; the dairy industry by Professor Kent on page 25; and poultry husbandry on page 85 by Professor Dryden.

The above table shows the value of live stock on the several sized farms. The state averages are $\$ 341, \$ 878, \$ 1,887, \$ 2,255$, and $\$ 8,030$, according to the several sizes of farms. These amounts are $3.6 \%, 4.7 \%, 8.2 \%, 8.1 \%$ and $14.9 \%$ of the respective total investments, as shown in the table on page 108. When it is remembered that the large farms greatly predominate, these rates are confirmed 
by the last census, which places the state average of live stock at 11.3 per cent. of the total value of farm property.

AVERAGE VALUEE OF IMPLEMENTS AND MACHINERY 1911-12.

\begin{tabular}{|c|c|c|c|c|c|c|c|c|c|c|}
\hline Division. & 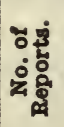 & 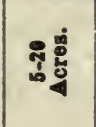 & 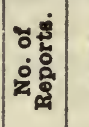 & \$ి & 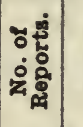 & 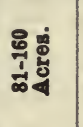 & 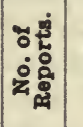 & 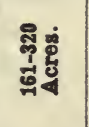 & 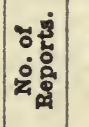 & 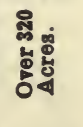 \\
\hline $\begin{array}{l}\text { Coast Division.... } \\
\text { Southern Oregon } \\
\text { Willamette Valleg. } \\
\text { Columbia Basin. } \\
\text { Blue Mountain... } \\
\text { Central Oregon... }\end{array}$ & $\begin{array}{r}2 \\
34 \\
35 \\
22 \\
10 \\
3\end{array}$ & $\begin{array}{r}100 \\
216 \\
220 \\
265 \\
200 \\
200\end{array}$ & $\begin{array}{r}25 \\
56 \\
149 \\
33 \\
9 \\
11\end{array}$ & $\begin{array}{l}287 \\
379 \\
443 \\
828 \\
359 \\
249\end{array}$ & $\begin{array}{r}56 \\
43 \\
131 \\
28 \\
11 \\
35\end{array}$ & $\begin{array}{l}437 \\
507 \\
554 \\
613 \\
678 \\
491\end{array}$ & $\begin{array}{r}52 \\
44 \\
126 \\
21 \\
32 \\
45\end{array}$ & $\begin{array}{r}\$ 425 \\
853 \\
826 \\
459 \\
394 \\
583\end{array}$ & $\begin{array}{r}34 \\
40 \\
99 \\
145 \\
101 \\
89\end{array}$ & $\begin{array}{r}532 \\
721 \\
1127 \\
1641 \\
840 \\
1227\end{array}$ \\
\hline State. & 106 & $\$ 223$ & $285 \$$ & 448 & $304 \$$ & 529 & $320 \$$ & $\$ 663$ & $608 \$$ & $\$ 1163$ \\
\hline
\end{tabular}

Value of Implements and Machinery.

A full discussion of farm management is found on page 33 by Professor Scudder. In this connection, however, it is interesting to note the report of the last census. On the subject of farm property we read: "The total wealth of the state in form of farm property is 528 million dollars of which 86.2 per cent is represented in land and buildings, 11.3 per cent by live stock, and 2.5 per cent by implements and machinery." The percentage of implements and machinery is remarkably close to those found in this survey on the different sized farms. The state average in tables on pages 101 and 103 are as follows: On a 5 to 20 acre farm the implements and machinery are 2.4 per cent. of the total capital; on 21 to 80 acres, 2.4 per cent; 81 to 160 acres, 2.3 per cent; 161 to 320 acres, 2.4 per cent; and above 320 acres, 2.1 per cent. The averages are fairly uniform in the several divisions of the state. The variations in the values of machinery are, doubtless, due mainly to the different types of farming; and to the variations in estimating value by the different farmers. The state averages are $\$ 223, \$ 448, \$ 529, \$ 663$, and $\$ 1,163$, according to the size of the farm, as shown in the above table.

AVERAGE GROSS INCOME 1911-12.

\begin{tabular}{|c|c|c|c|c|c|c|c|c|c|c|}
\hline Division. & 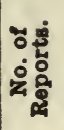 & 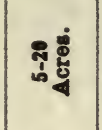 & 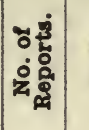 & 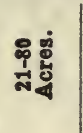 & 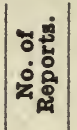 & 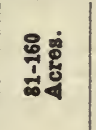 & 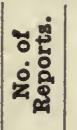 & 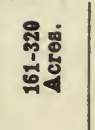 & 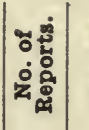 & 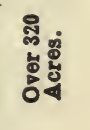 \\
\hline $\begin{array}{l}\text { Coast Division..... } \\
\text { Southern Oregon. } \\
\text { Willamette Valles. } \\
\text { Golumbia Basin... } \\
\text { Blue Mountain ... } \\
\text { Central Oregon... }\end{array}$ & $\begin{array}{r}3 \\
35 \\
35 \\
25 \\
10 \\
3\end{array}$ & $\begin{array}{r}786 \\
1419 \\
1451 \\
2399 \\
2580 \\
1517\end{array}$ & $\begin{array}{r}25 \\
57 \\
150 \\
33 \\
9 \\
14\end{array}$ & $\begin{array}{r}1743 \\
1880 \\
2474 \\
5656 \\
3600 \\
1462\end{array}$ & $\begin{array}{r}56 \\
43 \\
131 \\
29 \\
14 \\
34\end{array}$ & $\begin{array}{r}\$ 2176 \\
3076 \\
2970 \\
3318 \\
2913 \\
1891\end{array}$ & $\begin{array}{r}54 \\
46 \\
125 \\
22 \\
29 \\
45\end{array}$ & $\begin{array}{r}\$ 2163 \\
3991 \\
3487 \\
5996 \\
3638 \\
1940\end{array}$ & $\begin{array}{r}35 \\
41 \\
101 \\
146 \\
102 \\
90\end{array}$ & $\begin{array}{r}\$ 2665 \\
5893 \\
7800 \\
7674 \\
7829 \\
6133\end{array}$ \\
\hline State.. & 111 & $\$ 1738$ & $290 \$$ & 2625 & 307 & $\$ 2751$ & 321 & $\$ 3295$ & $615 \$$ & $\$ 6978$ \\
\hline
\end{tabular}




\section{Average Gross Cash Income.}

The average gross income on the different sized farms is found in the foregoing table. It is based on 1,544 reports. The smallest farm averaging 13 acres, shows a cash income of $\$ 1,738.00$, and the largest, 532 acres, $\$ 6,938.00$. The last average is based on the larger number of reports, and may, therefore, be regarded as the most reliable. The gross income includes only cash sales of products, and, in a few instances, returns for outside labor. No account was taken of the products used by the family, and sales of land and other capital goods were excluded.

AVERAGE CAPITAL INVESTED 1911-12.

\begin{tabular}{|c|c|c|c|c|c|c|c|c|c|c|}
\hline Division. & 范 & 옹ํํ & 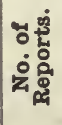 & 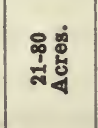 & 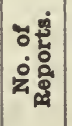 & 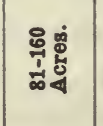 & 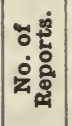 & 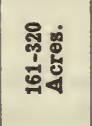 & 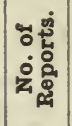 & 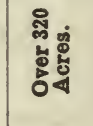 \\
\hline $\begin{array}{l}\text { Coast Division.... } \\
\text { Southern Oregon. } \\
\text { Willamette Valley. } \\
\text { Columbia Basin... } \\
\text { Blue Mountain... } \\
\text { Central Oregon... }\end{array}$ & $\begin{array}{r}3 \\
36 \\
35 \\
25 \\
10 \\
3\end{array}$ & \begin{tabular}{|r|}
$\$ 7471$ \\
8391 \\
8774 \\
11590 \\
11060 \\
7150
\end{tabular} & $\begin{array}{r}25 \\
56 \\
150 \\
35 \\
9 \\
14\end{array}$ & $\begin{array}{r}\$ 18976 \\
14005 \\
16479 \\
37740 \\
21058 \\
10595\end{array}$ & $\begin{array}{r}55 \\
44 \\
134 \\
28 \\
11 \\
37\end{array}$ & $\begin{array}{r}\$ 20776 \\
22807 \\
24607 \\
29789 \\
32116 \\
12827\end{array}$ & $\begin{array}{r}53 \\
45 \\
126 \\
22 \\
30 \\
47\end{array}$ & $\begin{array}{r}\$ 25357 \\
40087 \\
31864 \\
25504 \\
18677 \\
15893\end{array}$ & $\begin{array}{r}34 \\
40 \\
99 \\
147 \\
99 \\
90\end{array}$ & $\begin{array}{l}\$ 25323 \\
47254 \\
59922 \\
53154 \\
44153 \\
57156\end{array}$ \\
\hline State. & 112 & $\$ 9405$ & 289 & $\$ 18648$ & 309 & $\$ 23012$ & 323 & $\$ 27960$ & 509 & $\$ 53561$ \\
\hline
\end{tabular}

Average Investment.

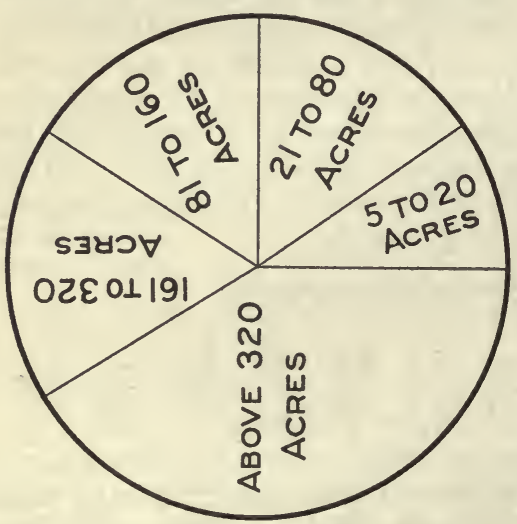

In the capital invested is included land, buildings, live stock, implements, and a moderate cash balance. Household goods, automobiles, and personal property not connected with the business end of farming are excluded. When the dwelling was reported above a fair proportion of the total investment, the excess was deducted, since only a reasonable amount should be charged to the business. This often happened on the small farms, where a $\$ 3,000$ to $\$ 5,000$ dwelling is not uncommon in some parts of the state. As will be seen from above table, by far the greater part of the capital is invested in land. As would be expected, this varies almost directly as the size of the farm increases, even in spite of the high valuation of the land in the small acreage farms. 
AVERAGE FAMILY EXPENSES 1911-12.

\begin{tabular}{|c|c|c|c|c|c|c|c|c|c|c|}
\hline Division. & 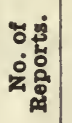 & శิํㅎㅇ & 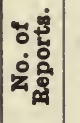 & 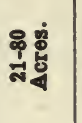 & 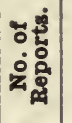 & 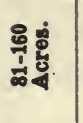 & 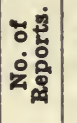 & 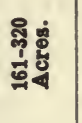 & 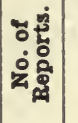 & 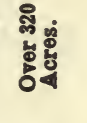 \\
\hline $\begin{array}{l}\text { lue Mountai } \\
\text { entral Orego }\end{array}$ & $\begin{array}{r}3 \\
37 \\
33 \\
24 \\
10 \\
2\end{array}$ & $\begin{array}{l}267 \\
448 \\
337 \\
439 \\
319 \\
425\end{array}$ & $\begin{array}{r}22 \\
57 \\
129 \\
31 \\
8 \\
17\end{array}$ & $\begin{array}{l}435 \\
483 \\
382 \\
444 \\
353 \\
214\end{array}$ & $\begin{array}{r}47 \\
44 \\
117 \\
25 \\
8 \\
42\end{array}$ & $\begin{array}{l}423 \\
578 \\
357 \\
433 \\
550 \\
320\end{array}$ & $\begin{array}{r}50 \\
46 \\
103 \\
21 \\
27 \\
45\end{array}$ & \begin{tabular}{l|}
374 \\
588 \\
441 \\
478 \\
566 \\
323
\end{tabular} & $\begin{array}{r}33 \\
42 \\
83 \\
141 \\
86 \\
89\end{array}$ & 60 \\
\hline & & 394 & $264 \$$ & 393 & 283 & 409 & $292 \$$ & 452 & 474 & \\
\hline
\end{tabular}

Average Family Expenses.

The family expenses include all items of cash outlay commonly regarded as living expenses. The principal items were groceries and clothing. A maximum of $\$ 50$ was allowed for each of the following

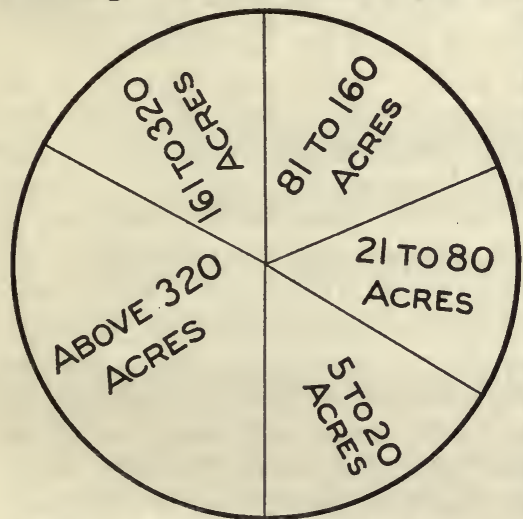
classes of expenditures, if reported at all: medical; recreation, including traveling, and educational expenses. Very much larger amounts were reported in some cases for this class of expenses, but they were regarded extraordinary and consequently reduced. In the majority of cases, the amounts reported were less than $\$ 50$ under each class. There appears to be a very slight difference between the family expenses on the different sized farms below 160 acres. The state average of the next two large classes of farms is $\$ 552$ to $\$ 635$ respectively. The above table gives a complete summary of the reports.

AVERAGE FAMILY INCOME 1911-12.

\begin{tabular}{|c|c|c|c|c|c|c|c|c|c|c|}
\hline Division. & 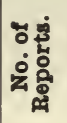 & 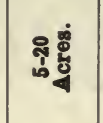 & 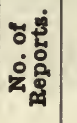 & 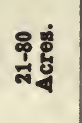 & 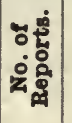 & 윰형 & 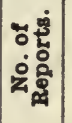 & 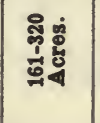 & 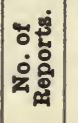 & 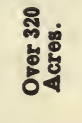 \\
\hline $\begin{array}{l}\text { Coast Division.... } \\
\text { Southern Oregon. } \\
\text { Willamette Valley. } \\
\text { Columbia Basin... } \\
\text { Blue Mountain. . } \\
\text { Central Oregon... }\end{array}$ & $\begin{array}{r}3 \\
24 \\
28 \\
22 \\
9 \\
\end{array}$ & $\begin{array}{r}\$ 358 \\
891 \\
852 \\
1709 \\
1487 \\
\ldots \ldots\end{array}$ & $\begin{array}{r}25 \\
40 \\
133 \\
31 \\
11 \\
9\end{array}$ & $\begin{array}{r}857 \\
1134 \\
1511 \\
3751 \\
2138 \\
780\end{array}$ & $\begin{array}{r}53 \\
29 \\
119 \\
23 \\
14 \\
30\end{array}$ & $\begin{array}{r}\$ 1179 \\
1528 \\
1762 \\
1658 \\
1504 \\
1088\end{array}$ & $\begin{array}{r}51 \\
37 \\
119 \\
20 \\
28 \\
32\end{array}$ & \begin{tabular}{|r|}
$\$ 1131$ \\
1959 \\
1908 \\
2373 \\
1358 \\
901
\end{tabular} & $\begin{array}{r}31 \\
34 \\
87 \\
133 \\
94 \\
75\end{array}$ & $\begin{array}{l}\$ 1313 \\
3447 \\
4307 \\
3841 \\
4193 \\
2834\end{array}$ \\
\hline State.... & 86 & $\$ 1132$ & 249 & 1665 & 268 & $\$ 1524$ & 28 & 1644 & 454 & 3642 \\
\hline
\end{tabular}




\section{Average Family Income.}

The family incomes as shown in the table were obtained as follows: From the net income, or the amount remaining after the business

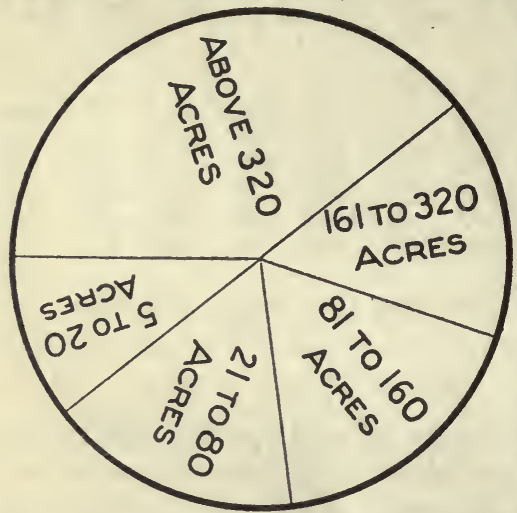
expenses were deducted from the gross income, was deducted the the total living expenses, the remainder being the net family income. The total family expenses were taken just as given by the farmer, except that not more than $\$ 50$ was allowed for each of the following: education, recreation, and doctor bills. Expressed in another way, the farmer was allowed the living of himself and family except that a limit of $\$ 50$ was placed on recreation, education and medical bills. No limit was placed on clothing or household bills. Thus the family income includes the interest on the capital invested and wages for the family labor.

In every case the per cent of net profit or loss was figured on the value as given by the farmer; and in nearly every case the value was about one-half greater than the value five years ago. In the case of stock farms, a report often showed a large receipt for stock sold; or a large payment for stock bought. In the absence of inventories at the beginning and end of the year, it was impossible to tell what part of the receipts from a sale was a profit and what part original cost. For instance, a man could sell all his stock and show large receipts, increasing the per cent gain for the year. But he would be making an alleged profit by reducing his capital. It was considered that for all persons interviewed, the total stock owned by them would be constant, or about the same at the beginning as at the end of the year. Also that the total sales less the total purchases would leave the total net profit on the stock bought and sold by the stock raisers. It is believed that the number averaged were sufficient to offset possible errors in such cases.

AVERAGE RATE OF PROFIT, INCLODING FAMILY LABOR 1911-12.

\begin{tabular}{|c|c|c|c|c|c|c|c|c|c|c|}
\hline Division. & 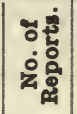 & 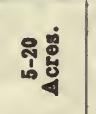 & 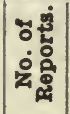 & 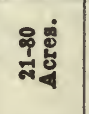 & 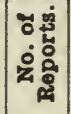 & 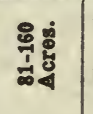 & 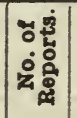 & 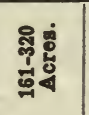 & 范 & 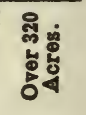 \\
\hline & \begin{tabular}{r|}
3 \\
23 \\
28 \\
22 \\
9
\end{tabular} & $\begin{array}{r}\% \\
4.37 \\
7.70 \\
7.37 \\
10.22 \\
14.28\end{array}$ & \begin{tabular}{|r|}
25 \\
40 \\
132 \\
32 \\
10 \\
9
\end{tabular} & $\begin{array}{l}\% \\
4.92 \\
8.41 \\
8.36 \\
7.97 \\
8.89 \\
7.04\end{array}$ & \begin{tabular}{|r|}
52 \\
29 \\
117 \\
22 \\
13 \\
27 \\
\end{tabular} & & \begin{tabular}{|r}
50 \\
37 \\
116 \\
19 \\
28 \\
31
\end{tabular} & $\begin{array}{l}\% \\
5.95 \\
5.07 \\
6.80 \\
9.90 \\
6.68 \\
6.49\end{array}$ & $\begin{array}{r}31 \\
34 \\
84 \\
132 \\
92 \\
71\end{array}$ & \\
\hline & & & & & & & & & & \\
\hline
\end{tabular}




\section{Average Rate of Profit and Family Labor.}

The Oregon farmer is prosperous. He is making a good living and a reasonable rate of interest on his investment. This is the central fact which appears from the table herewith. It does not matter which division is showing the largest rate of profit. That depends largely on the valuation placed on the land, but the important fact which appears evident is that in every section of the state, well managed farms are returning a satisfactory profit on the capital invested.

It may be objected that since the rates given include the family labor, in many cases, the rate of profit would be reduced to a minus quantity were the family labor paid a reasonable wage. This would doubtless be true in some instances, but would not hold as an average of a large number of farms. The value of a comfortable living, including dwelling, clothing, food, schooling, doctor bills and many luxuries, and a fair allowance for recreation, is more than the average mechanic enjoys in town, to say nothing of a steady increase in land values. The last census shows a rise in land values of considerably over $200 \%$ in every section of the state. (See table on page 107).

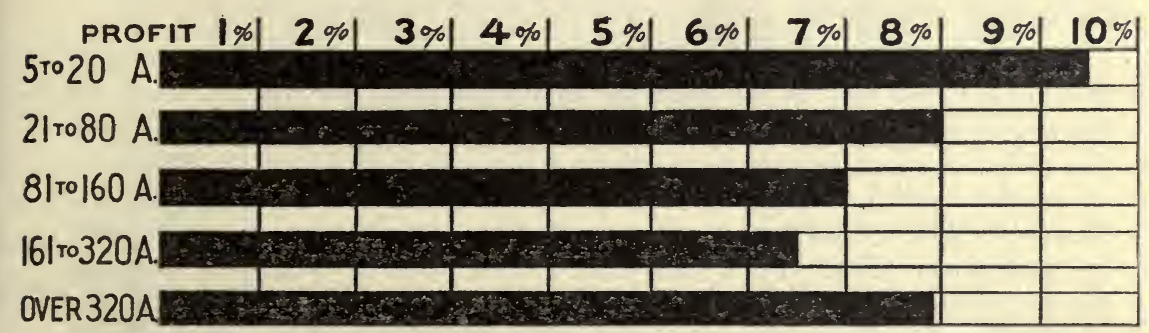

The average value of the dwelling, as shown in the table on page 100 , would be more than double added. Ordinary driving vehicles and horses, and many items of capital were included which no one would think of charging to the operating expenses of any other kind of business. To rent as good a home and save as much as the average Oregon farmer has saved would require an income far in excess of the wages of an ordinary mechanic or small trader. Add to this the joy of an independent vocation, and it must be admitted that the average farm offers far greater advantages than most other vocations.

It is not my purpose to enter into a discussion of the results found in the different sections. The results are, of course, only close approximations. One thing stands out clearly, and that is, the small farm is the most profitable in many parts of the state while the larger farm is the profitable unit in Eastern and Central Oregon.

Only one rate requires special explanation. I refer to the prefit of over fourteen per cent on the small farms in the Columbia Basin. This must be due largely to a number of highly productive irrigated farms in the Freewater, Milton, Cove, and Hood River districts. 
This is more fully explained under the horticultural section, page 71 . The principal reason for the high rate of profit on the small farms in this section is, doubtless, due principally to irrigation, and to the variety of many crops found on most of these small farms. On page 82 , is described two of these farms which illustrate this point.

For a graphical representation of the state averages, see table page 104.

STATISTICS ON BUSINESS METHODS 1911-12.

\begin{tabular}{|c|c|c|c|c|}
\hline \multirow{2}{*}{ Division. } & \multicolumn{2}{|c|}{$\begin{array}{l}\text { Reports showing } \\
\text { Bank Account. }\end{array}$} & \multicolumn{2}{|c|}{$\begin{array}{l}\text { Reports showing } \\
\text { Records Kept. }\end{array}$} \\
\hline & $\begin{array}{c}\text { No. } \\
\text { Reports. }\end{array}$ & $\begin{array}{l}\text { Per } \\
\text { Cent. }\end{array}$ & $\begin{array}{c}\text { No. } \\
\text { Reports. }\end{array}$ & $\begin{array}{l}\text { Per } \\
\text { Cent. }\end{array}$ \\
\hline $\begin{array}{l}\text { Coast Division ......... } \\
\text { Southern Oregon...... } \\
\text { Willamette Valley....... } \\
\text { Columbia Basin ........ } \\
\text { Blue Mountain .......... } \\
\text { Central Oregon........ }\end{array}$ & $\begin{array}{l}174 \\
187 \\
538 \\
251 \\
175 \\
196\end{array}$ & $\begin{array}{l}89 \\
95 \\
94 \\
95 \\
95 \\
89\end{array}$ & $\begin{array}{l}174 \\
174 \\
528 \\
246 \\
180 \\
194\end{array}$ & $\begin{array}{l}42 \\
77 \\
38 \\
30 \\
30 \\
33\end{array}$ \\
\hline State....... & 1,521 & 93 & 1,496 & 48 \\
\hline
\end{tabular}

\section{Business Methods.}

The claim that the farmer is more careless regarding his business methods than any other class of business men was doubtless once true, but there are indications that this condition is rapidly changing. No other subject has received more attention in the last few years by educators and economists throughout the United States than the Business Side of Farming. Farm Credit and Finance have become international issues; marketing and distribution of farm products are receiving increased attention. Every educational institution from the Agricultural College down to the cross road school is emphasizing this important subject.

Two questions were asked in the survey for the purpose of ascertaining the business methods of the Oregon farmer, and the reports were truly surprising. The questions were: (1). Do you keep permanent records of your business transactions? and (2) Do you keep a bank account? Nearly 1,500 answers were secured to the first question and 1,521 to the second. In the above table it appears that 93 out of every 100 farmers interviewed keep a bank account, and that 48 out of every 100 keep some kind of financial records. This is a showing of which Oregon may be justly proud; since it reflects in a large measure the intelligence and character of the farming population. Professor Warren, in his survey of Tompkins County, New York, estimates that 45 per cent of the farmers in that county keep records - a rather remarkable similarity of results as compared with this survey.

This table also shows remarkable uniformity throughout the state, especially in regard to banking practice, two divisions showing $95 \%$, one $94 \%$ and two $89 \%$. Southern Oregon shows a decided lead in regard to record keeping. 


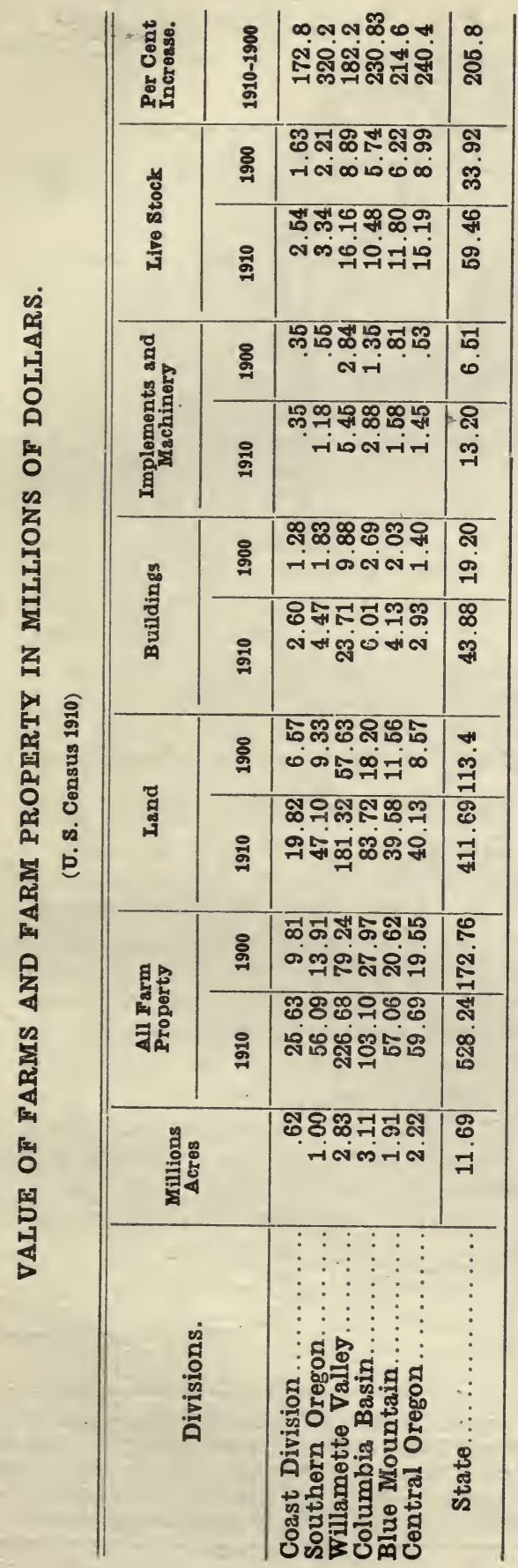

సే

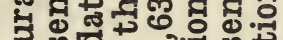

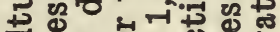

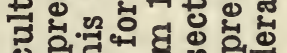

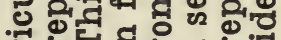

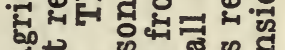

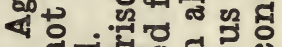

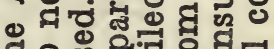

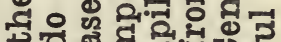
फ न

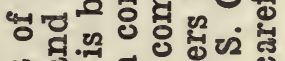
$\uparrow$ ๙ु.

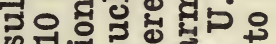

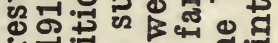

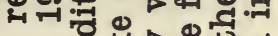
엉 녕용ㅎㅀ 건에 v2 겅 ๒ै द्व t낭 엉ㅇㅇㅇㅝ 이요

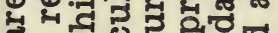
సै ध o 5 舟

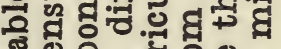
† कo थ

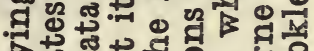

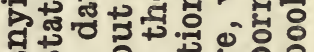

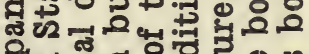

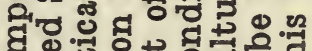

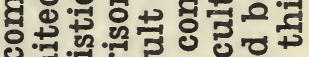
을 웍

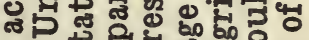
0 ข

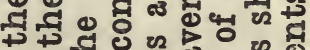

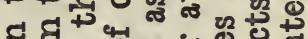

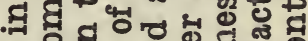
언.न

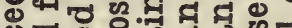

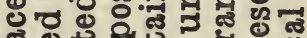

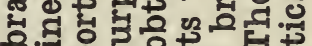
다웡

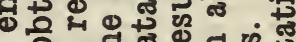
ช 응 연 언 응 . ॠ †

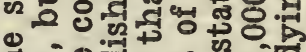

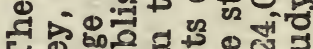
- 0 क दै

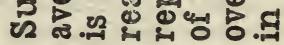




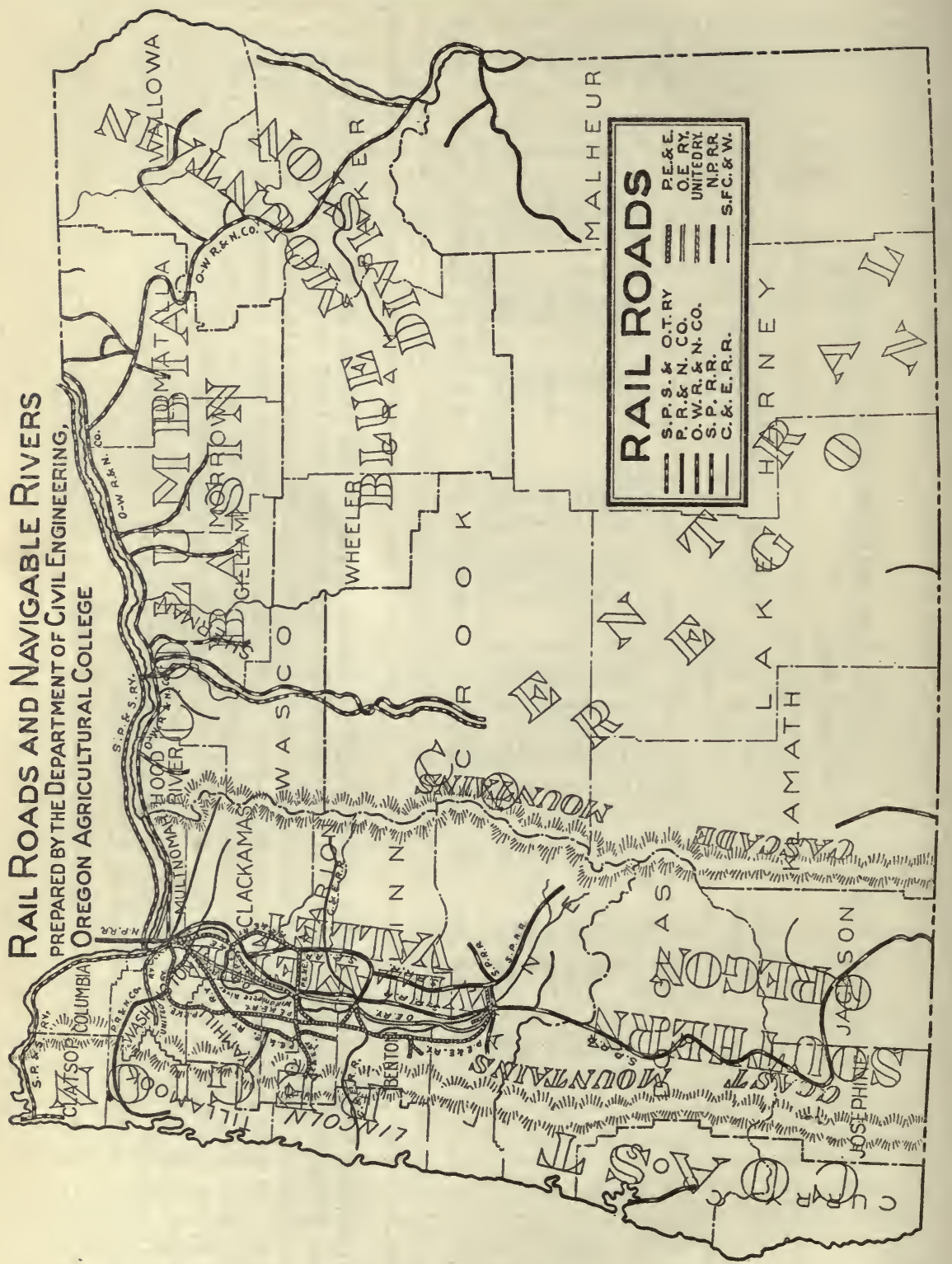

Fvery rallroad company doing business in Oregon pays special attention to the development of the agricultural industry in the State and works through all possible channels for its encouragement. Evory transportation company has exceptional opportunities for the small farmer. They make liberal provision for handling the products between railroad stations and consumers of the products in the eities. 


\section{COUNTRY LIFE IN OREGON.}

By Hector Macpherson,

Professor of Economics.

$7(\mathrm{~N}$ the tables accompanying this chapter, we have condensed the 5 main social facts brought out by the Preliminary Rural Survey of our state. The critical student will see at a glance that the material is too scanty to afford the basis for a very satisfactory discussion of country life. In fact, life in either country or city, in Oregon as elsewhere, is too big and too complex to be reduced to such simple statistical form. Valuable material may be so expressed; but the collection of adequate statist: ral information on country life would entail an investigation much broader in scope and more minute in detail than the Oregon Statistical Bureau was able to undertake in this preliminary survey.

However, every field man was required to write up a general report on each neighborhood visited; and, while the information contained in these reports is not of a nature which admits of tabulation, it contains many interesting side-lights on country life in all parts of the state.

Besides, the writer has freely used such material as was available from the recently published Oregon Almanac, advance sheets of the 1910 Census, Histories of Oregon, and personal interviews with men familiar with country life in all parts of the state.

\section{The People and Their Heritage.}

The essential factors in the upbuilding of a high type of rural civilization are two: the environment and the people. Both these factors are equally important. In a harsh, barren and unproductive country, the finest human type cannot be developed in sufficient numbers to make social progress possible. On the other hand, the most bountiful natural resources, may go to waste for ages under the control of an unprogressive population.

In both the elements essential to progress, Oregon is already richly endowed. In natural resources, she has a splendid heritage. Of her immense area of 97,699 square miles, it is estimated that there are about 23,000,000 acres suited to agriculture. A glance at the accompanying diagram and explanatory key will show the present distribution of Oregon's land area.

In all probability, the time will come when half of this $61,000,000$ acres will be carefully cultivated. At least, when one thinks of the beautifully terraced hillsides in the mountain districts of Italy, Switzerland, 'France, and Germany, one cannot but have a vision of our Western Oregon foothills clothed in fruitful trees, vines and shrubs; and imagine he hears the mountains ringing with the shouts and laughter of a healthy, freedom loving, population.

But with $23,000,000$ acres of arable land to till, we shall have little reason to resort to terraced hill-sides for many years to come. On an 


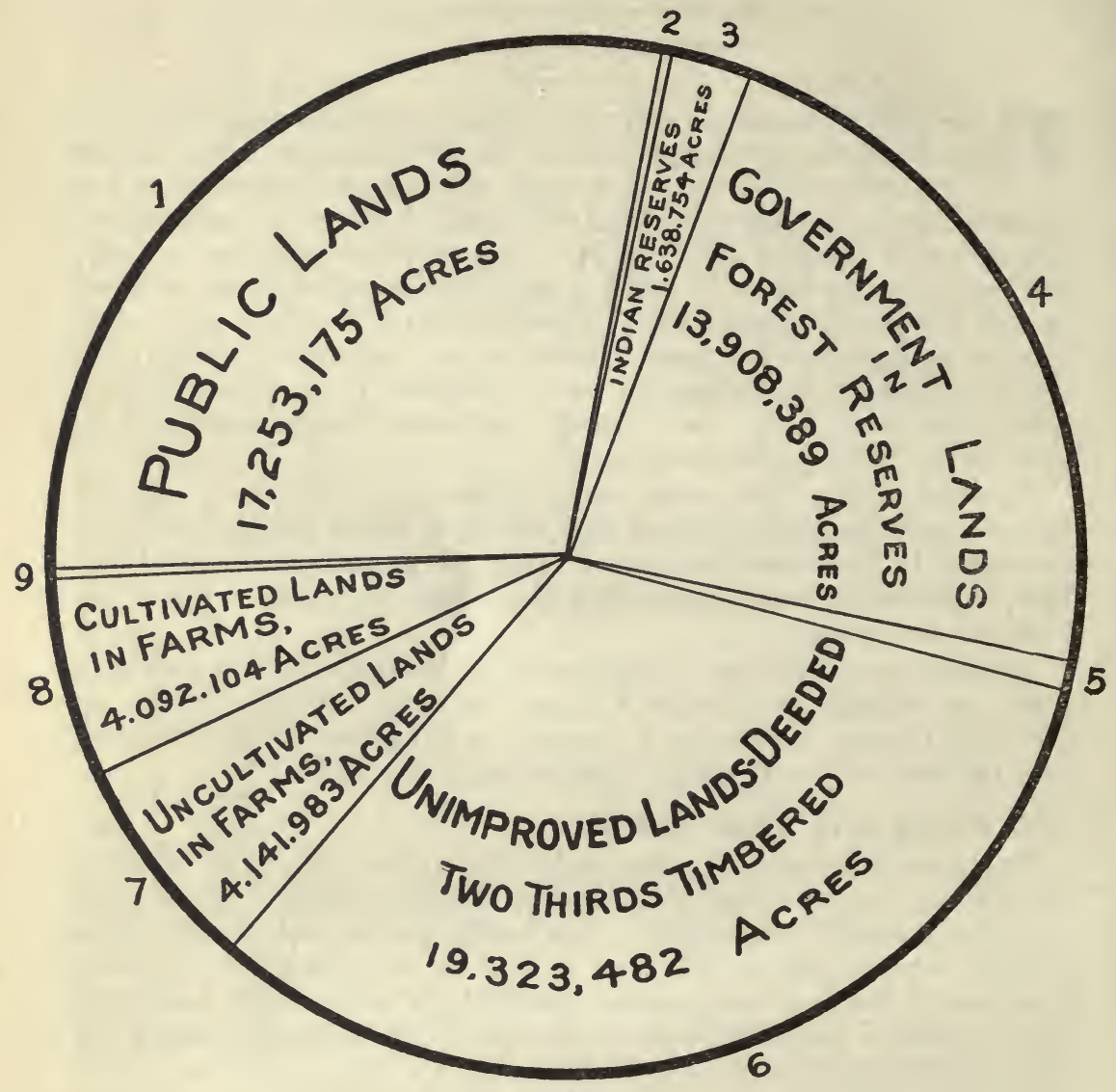

area of less than $10,000,000$ acres of much poorer land Denmark has built up one of the most prosperous nations in the world, with a population four times as great as we now have in Oregon. But the reader who has weighed the facts of the preceding chapters, will have been convinced that Oregon is capable of supporting ten times its present population, without at all crowding its splendid natural resources.

Possessing one-fifth of the standing timber of the United States, with fisheries returning over $\$ 6,000,000$ last year, with mineral resources of undoubted value though largely unexplored, and having streams with $3,300,000$ electrical horse power waiting to be harnessed, surely Oregon's agriculture ought to be well supported by other industries giving encouragement to the fullest utilization of her agricultural resources by markets right at home. 


\section{Climate.}

Along with her fertile soil and abundant natural resources, the climate of Oregon is an attraction to people of the East. Those who have breasted the cyclone, braved the flood, hibernated through frigid winters, and panted in the shade through sweltering summers, are sure to welcome a change to the genial winters and cool bracing summers of Oregon. To be sure, some complain of the rainy months of the Western Oregon winter. Some even return after the first year to their old home in the East; but in nine cases out of ten, they find their former haunts have lost their charm, and they return to Oregon poorer but wiser men.

Let them but remain a couple of winters, until the proverbial web has begun to unite the toes of each foot into a congenial group, then they will never be anything else but Western Oregonians. They turn blue under two degrees of frost, shiver at the thought of an Eastern winter, and blossom out in rosy cheeks during the steady rains of December and January. In fact, we are all agreed out here that rain suits us much better than snow. It makes the kale heads large and succulent for our poultry and dairy cows. It keeps the grass on our hillsides fresh and green to delight the eye, and feed our flocks of sheep and Angora goats. Should anyone, however, wish to escape the winter rains, he has but to cross the Cascades. Here he will find a climate combining the best features of the East, but free alike from its sweltering heat and benumbing cold.

Another feature of the Oregon climate which appeals to most Eastern people is its freedom from dangerous or damaging storms. The man who has braved the tornado and breasted the flood, will find here a haven where even severe electrical storms seldom or never occur.

No better commentary could be required on the climate of Oregon than is afforded by the health statistics of her population. According to the report of Dr. Calvin S. White, Secretary Oregon State Board of Health, "Oregon ranks highest among the states of the Union in the low rate of mortality, the annual death rate for the year 1911, for Portland, where the official record is kept, being 9.47 per 1000 of population". Again he says: "Our infant mortality is almost incredibly low, and the boy or girl born into Oregon has every likelihood of attaining a ripe old age."

\section{The People of Oregon.}

It has been said that there is no other western state in which the Easterner feels so much at home as he does in Oregon. Such a statement contains both truth and falsehood. It is true that the wildness and wooliness of the frontier, which has left certain marks of its crudity upon a large part of our American West, made little or no impression on Oregon. It is also noteworthy that in the serious moral tone of its inhabitants, Oregon compares favorably with the most straight-laced sections of the East. 
But when we come to sound the undercurrents of Oregon life, we find that it parts company radically with life in the East. Oregon people are just as moral as those of the older Eastern states; but have less of prudishness. They are more courteous, on the average, but less snobbish. They support what is best in the institutions of the East, but refuse to be enslaved by the machinery of those institutions. Oregonians are fairly conservative; but they never bar progress by a reverence for what is old merely because it is old. Nor do they condemn the new for no other reason than that it is new.

In brief, we may say that when an institution or a law is honestly framed to blaze out new trails for the pathway of progress, it will look long ere it finds more sympathetic and intelligent consideration than it will receive from the people of Oregon.

To realize the truth of these bald statements, it will be necessary to recall a few facts of Oregon history. First of all, we must remember that, paradoxical as it may seem, Oregon is an old new state. Six years before the discovery of gold had started the indiscriminate throngs of fortune hunters on their mad race for California, the basis for Oregon's population was being laid under much more favorable circumstances.

The latter thirties and earlier forties, saw the rapid settlement of the Middle West and South West which followed the opening of the Erie Canal, and the development of steam navigation on the Mississippi. It was an era of scant markets and an oversupply of agricultural products. The people were restless; and the westward impulse was strong in every breast. Glowing accounts of lands nearer the setting sun, and especially of the almost unknown Oregon country, stirred impulse into action.

Moved as by a common instinct, there assembled in the spring of 1843 , at Independence, Missouri, a band of about 875 men, women, and children, eager to set out for the land beyond the mountains. They began their journey May 20,1843, and in the fall of that year the advance guards descended upon their land of promise, the Willamette Valley.

Although stragglers and small groups had settled in Oregon previous to this migration, the influx of 1843 marks the real beginning of the American occupations of the territory then under dispute between Great Britain and the United States. The year 1844 saw about 1400 more Americans added to their ranks; and the following year, they were joined by a new influx of about 3,000 men, women and children.

Whatever may be our convictions on some of the much disputed points of this period of our history, it seems to me that we must acknowledge this tide of immigration to have been an element in settling this question of ownership of the Oregon country. But apart from whatever influence it may have had in determining the 
question of the flags, this immigration was a momentous occurrence in moulding the future of the North West and especially of Oregon.

It provided the ancestry for a large proportion of our present population. It laid the foundation for that serious moral purposefulness which is one of the distinctive characteristics of Oregonian character.

On this foundation stock for the Oregon breed of men and women, F. V. Holman, in his "Dr. John McLoughlin", (p. 84), writes as follows: "A great majority of the immigrants to Oregon from 1843 to 1846 , inclusive, and some of the later immigrants, were from the Southern States. They, and their ancestors for many generations, had been born and brought up in the South. Most of them had the good qualities and were of the high type of American citizenship characteristic of the white people of the South. They were mostly plain people, but they and their ancestry were of good class. Theirs was an inheritance of indomitable will, high courage and noble purposes. Their ancestors had conquered, settled, and upbuilded the country from the seaboards of Virginia and the Carolinas to the Mississippi River. Oregon was another land to conquer, to settle and to upbuild".

These earliest settlers took their choice of the best lands, and their descendants now form a large percentage of the wealthier, more conservative elements in our population. They have prospered and multiplied, until, their children and children's children are to be found in every walk of life. Although many of the younger generation have a!ligned themselves with the progressive forces of the state, we are inclined to give much of the credit for Oregon's aggressive application of the principles of democracy to the newer elements of our population.

After almost a half century of comparative neglect, Oregon has within the past ten or fifteen years, begun again to attract the attention of homeseekers. It is putting it conservatively, I think, to assert that she has been getting an exceptionally large proportion of the most desirable citizens. Business men, professional men, and college graduates, from far and near, have been buying land and settling down to build for themselves country homes in Oregon. Many of them, to be sure, have been deluded into false hopes by the exaggerated claims of speculating land companies. But even these, after the first revulsion of feeling, have frankly recognized the solid worth of the state. They have brought their education and business training to bear upon the problems of our rural life in a way which will ultimately place the progress of Oregon on a much firmer basis than would have bcen possible in any such get-rich-easy Utopia as the land speculators depicted.

The greatest need of Oregon today is for a denser rural population. With an estimated arable area of $23,000,000$ acres, we have, as indicated by the accompanying diagram, a total rural population of only 337,000 , an average of 3.6 persons to the square mile for the whole 


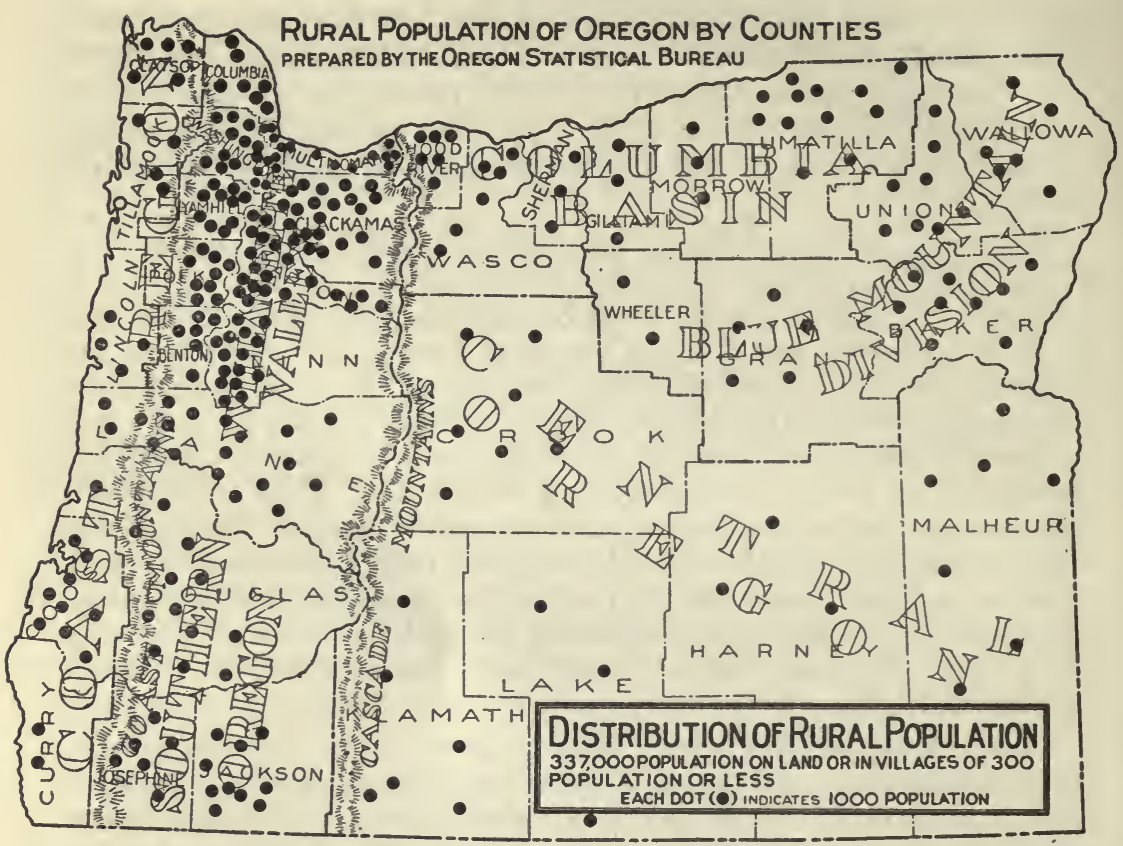

state, including those living in villages of 300 inhabitants or under. But even this does not tell the whole story. Referring again to the statistical map of rural population, we_notice that the majority
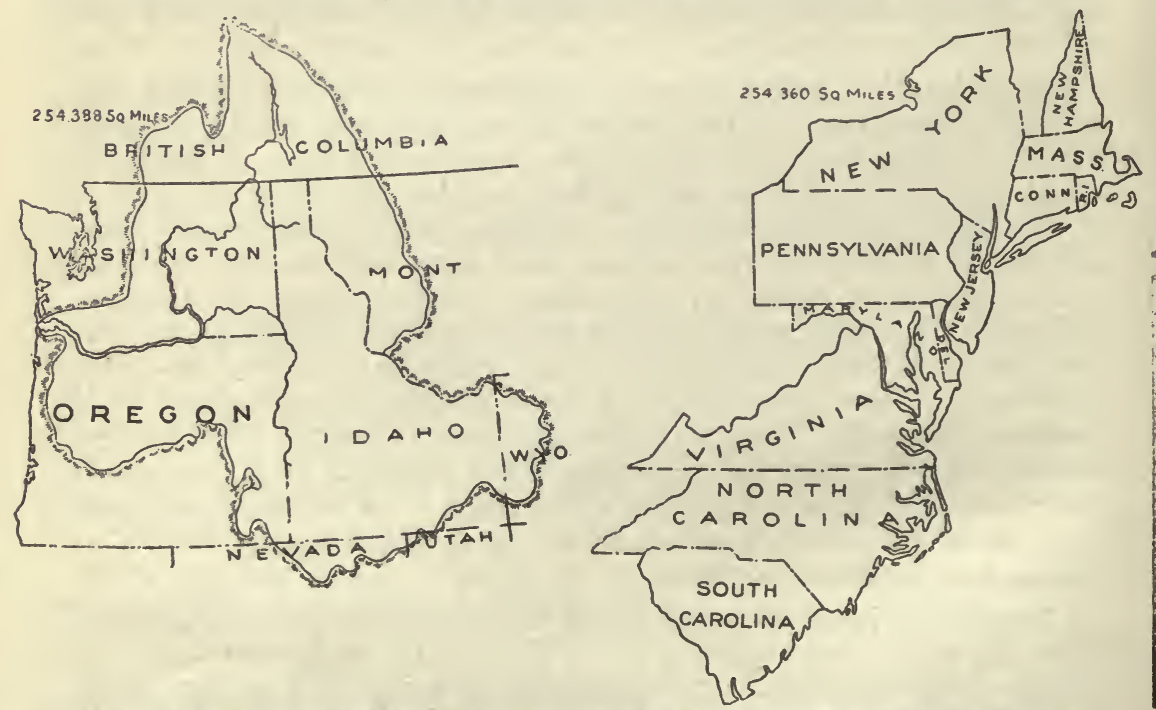

Columbia River drainage area larger than the thirteen original states, except Georgia. 
of our rural dwellers are located in a comparatively small section of the state. This means a still greater sparsity of population over most of our rural area.

These facts about our population must be constantly borne in mind as we proceed to treat the other factors which enter into the make-up of our rural life.

\section{Communication and Transportation.}

At the foundation of the systems of communication and trans$r$. rtation of any country lies its public highways. This is a fact which has as yet taken hold of the people in but a very small percentage of our American states. At this very moment the Chicago newspapers are carrying on a campaign for better roads in Cook County. Cartoonists are depicting horses mired, and vehicles up the axles in mud. We assure the truck gardener from around Chicago, that if he should cast his lot with us on the Pacific Coast he will be able to find some pieces of road in Oregon just as bad as those of Cook County. Should he become very homesick he might drive through one of our worst pieces. He'll have no difficulty in imagining that home and mother are waiting for him at the other end of the haul, as so often happened near Chicago.

Highway construction in Oregon has its difficulties to contend with. But it also has certain advantages. The hilly nature of the country through the coastal range and other mountainous sections presents the difficulty of steep grades to overcome. On the other hand, the slopes give a natural drainage which prevents the mountain roads from becoming wallowing quagmires such as frequently occur in the valleys and on the plains. Then, too, there are few parts of Oregon which have not fairly easy access to materials for road building.

The good roads movement is gaining ground in Oregon, as it is in every other state. The chief obstacles to be overcome are, lack of interest in the older sections, and sparseness of population in newer districts. At present, practically all the settlements of the state are reached by public highways of some sort; while many of the more progressive and thickly settled rural communities have macadamized their principal highways. The foremost men in the new rural life movement see the necessity of some unified scheme of highway improvement for the whole state, and are working toward that end. The Oregon Almanac gives the amount spent in highway improvement for the whole state, at approximately $\$ 11,754,757$ for for the six year period, 1906-1912.

The map on page 108 shows at a glance the present railway situation in Oregon. As indicated, large areas of the state are still in their stage coach days, while the Willamette Valley is fairly laced with railways.

The old adage, "it never rains but it pours" is well illustrated here as well as in the northern part of the state. Those sections which 
are best provided with railways have also abundant facilities for transportation by water. The Columbia is navigable throughout the year as far as The Dalles, and the Willamette to Salem. Except for the period of low water, both rivers have regular service for much longer distances. For about nine months of the year the Columbia is navigable to Priest Rapids, Washington, and to Iewiston, Idaho; while the regular service of the Willamette reaches Corvallis, except during low water.

However, the best settled sections of the state have regular transportation facilities for agricultural products by either rail or water; and as fast as other areas are sufficiently developed, present lines are being extended and new ones built.

\section{Postal Service and Telephone.}

SOCIAI STATISTICS-A.

\begin{tabular}{|c|c|c|c|c|c|c|c|c|c|c|c|c|}
\hline \multirow[b]{2}{*}{ Division. } & \multicolumn{3}{|c|}{ Nationality. } & \multicolumn{3}{|c|}{$\begin{array}{c}\text { Rurai Free } \\
\text { Delivery. }\end{array}$} & \multicolumn{3}{|c|}{ Telephone. } & \multicolumn{3}{|c|}{$\begin{array}{l}\text { Buttermaking by } \\
\text { Women at Home. }\end{array}$} \\
\hline & $\begin{array}{l}\text { No. of } \\
\text { Reports. }\end{array}$ & Am. & For. & $\begin{array}{l}\text { No. of } \\
\text { Reports. }\end{array}$ & Yes & No & $\begin{array}{l}\text { No. of } \\
\text { Reports. }\end{array}$ & Yes & No & $\begin{array}{l}\text { No. of } \\
\text { Roports. }\end{array}$ & Yes & No \\
\hline $\begin{array}{l}\text { Coast Division... } \\
\text { Southern Oregon. } \\
\text { Willamette Valley } \\
\text { Columbia Basin.. } \\
\text { Blue Mountain... } \\
\text { Central Oregon... }\end{array}$ & $\begin{array}{l}172 \\
207 \\
491 \\
242 \\
162 \\
209\end{array}$ & $\begin{array}{l}123 \\
169 \\
366 \\
219 \\
141 \\
165\end{array}$ & $\begin{array}{r}49 \\
38 \\
125 \\
23 \\
21 \\
44\end{array}$ & $\begin{array}{l}176 \\
238 \\
494 \\
203 \\
189 \\
169\end{array}$ & $\begin{array}{r}87 \\
134 \\
399 \\
80 \\
77 \\
56\end{array}$ & $\begin{array}{r}89 \\
104 \\
95 \\
123 \\
112 \\
113\end{array}$ & $\begin{array}{l}175 \\
246 \\
546 \\
204 \\
183 \\
186\end{array}$ & $\begin{array}{l}137 \\
201 \\
500 \\
168 \\
153 \\
102\end{array}$ & $\begin{array}{l}38 \\
45 \\
46 \\
36 \\
30 \\
84\end{array}$ & $\begin{array}{l}125 \\
329 \\
513 \\
191 \\
115 \\
179\end{array}$ & $\begin{array}{r}62 \\
164 \\
429 \\
150 \\
99 \\
126\end{array}$ & $\begin{array}{l}63 \\
65 \\
84 \\
41 \\
16 \\
53\end{array}$ \\
\hline State............. & 1483 & 1183 & 300 & 1469 & 833 & 636 & 1540 & 1261 & 279 & 1352 & 1030 & 322 \\
\hline
\end{tabular}

The eagerness with which Oregon farmers improve their means of communication is well illustrated by the above statistics on the use of the rural telephone and Rural Free Delivery. It is interesting to note the large number of farms visited in all parts of the state which make use of the rural telephone. Even in the most sparsely settled divisions of the state, a large percentage of the farmers are in actual speaking contact with the outside world. Roads may be bad, and distances too great to admit of postal rural free delivery of mail; but along the lines of privately or mutually owned telephones, the news of the outside world penetrates the remotest neighborhoods. The farmer and his family are often alive to the topics of the day long before the information could reach him by the slower method of the local post office.

In but few sections of Oregon, need the settler long face the deadening isolation which formerly confronted the pioneer. Into all parts of the state the rural telephone is carrying its message of cheer and social unity. Following it is the rural free delivery with its parcel post service which further cements the farmer to the world of thought and industry of which he forms a part. A "study of the above table in connection with the Division Map of the state, page 7, tells the story more eloquently than it could be expressed in words. 


\section{Educational Facilities.}

SOCIAL STATISTICS-B.

\begin{tabular}{|c|c|c|c|c|c|c|c|c|c|c|c|c|}
\hline \multirow[t]{2}{*}{ Division. } & \multicolumn{3}{|c|}{$\begin{array}{l}\text { Access to } \\
\text { Iibrary. }\end{array}$} & \multicolumn{3}{|c|}{$\begin{array}{c}\text { Access to } \\
\text { High School. }\end{array}$} & \multicolumn{3}{|c|}{$\begin{array}{c}\text { Agriculture } \\
\text { Taught. }\end{array}$} & \multicolumn{3}{|c|}{$\begin{array}{l}\text { Influence of } \\
\text { Church Increating. }\end{array}$} \\
\hline & $\begin{array}{l}\text { No. of } \\
\text { Reports. }\end{array}$ & Yes & No & $\begin{array}{l}\text { No. of } \\
\text { Reports. }\end{array}$ & Yes & No & $\begin{array}{l}\text { No. of } \\
\text { Reports. }\end{array}$ & Yes & No & $\begin{array}{c}\text { No. of } \\
\text { Reports. }\end{array}$ & Yes & No \\
\hline $\begin{array}{l}\text { Coast Division.... } \\
\text { Southern Oregon. } \\
\text { Willamette Valley } \\
\text { Columbia Basin.. } \\
\text { Blue Mountain... } \\
\text { Central Oregon... }\end{array}$ & $\begin{array}{r}96 \\
119 \\
462 \\
197 \\
149 \\
195\end{array}$ & $\begin{array}{r}60 \\
61 \\
379 \\
108 \\
105 \\
169\end{array}$ & $\begin{array}{l}36 \\
58 \\
83 \\
89 \\
44 \\
26\end{array}$ & $\begin{array}{l}158 \\
177 \\
468 \\
235 \\
143 \\
187\end{array}$ & $\begin{array}{r}72 \\
96 \\
321 \\
161 \\
99 \\
76\end{array}$ & \begin{tabular}{r|}
86 \\
81 \\
147 \\
74 \\
44 \\
111
\end{tabular} & $\begin{array}{r}88 \\
75 \\
244 \\
179 \\
76 \\
159\end{array}$ & $\begin{array}{r}40 \\
7 \\
64 \\
74 \\
13 \\
43\end{array}$ & $\begin{array}{r}48 \\
68 \\
180 \\
105 \\
63 \\
116\end{array}$ & $\begin{array}{r}64 \\
105 \\
322 \\
105 \\
87 \\
111\end{array}$ & $\begin{array}{r}42 \\
95 \\
284 \\
81 \\
72 \\
89\end{array}$ & $\begin{array}{l}22 \\
10 \\
38 \\
24 \\
15 \\
22\end{array}$ \\
\hline State... & 1218 & 882 & 336 & 1368 & 825 & 543 & 869 & 241 & 628 & 794 & 663 & 131 \\
\hline
\end{tabular}

There is little excuse for any child's growing up illiterate in Oregon. A little work among the figures of the Thirteenth Census will show that she ranks high among the states of the Union, both in the number of her teachers and in her annual expenditures for education, in proportion to her population. As the "Oregon Almanac" puts it: "Oregon, ranking thirty-fifth in population, ranks twenty-third in amount of salaries paid to teachers, and twenty-first in the total expenditures for public school purposes, in the latter respect ranking ahead of the great states of Alabama, Arkansas, Florida, Georgia, Maine, Mississippi, North Carolina, North Dakota, and South Dakota, each of which contains a much larger population." For the year 1911, Oregon employed 4,969 teachers, spent $\$ 2,659,727$ in salaries, and made a total expenditure for educational purposes of $\$ 5,731,902$.

The standard of the common schools is being raised every year, a more thorough training is being demanded of our teachers, and efforts are being made as never before to correlate education and life work. Of the high schools, more are offering a full four year course; and each year sees a larger number of them offering scientific agriculture as a part of their regular work.

Referring to "Social Statistics" B, above, we notice that, of 1,368 families reporting, 825 had access to a high school; and of these, 241 reported agriculture as one of the regular subjects taught.

Higher education in Oregon is amply provided for in its State University at Eugene, and the Agricultural College at Corvallis. Both of these schools are progressive, and are working on the Wisconsin plan of carrying education right to the homes of the people. An Extension Educational Bill, passed by the last session of the Legislature, the provisions of which are carried out jointly by the State Department of Education and the Agricultural College, places Oregon in the front rank among the states in the democratization of education. It is so planned as to reach practically every man, woman, and child in the state.

Besides, Oregon possesses in Reed College of Portland a richly endowed independent school of liberal arts, which aims at the very highest standards, and is already having an appreciable influence on the educational policy of the state. Then, for those who prefer to send their children to a denominational school, Oregon can supply 


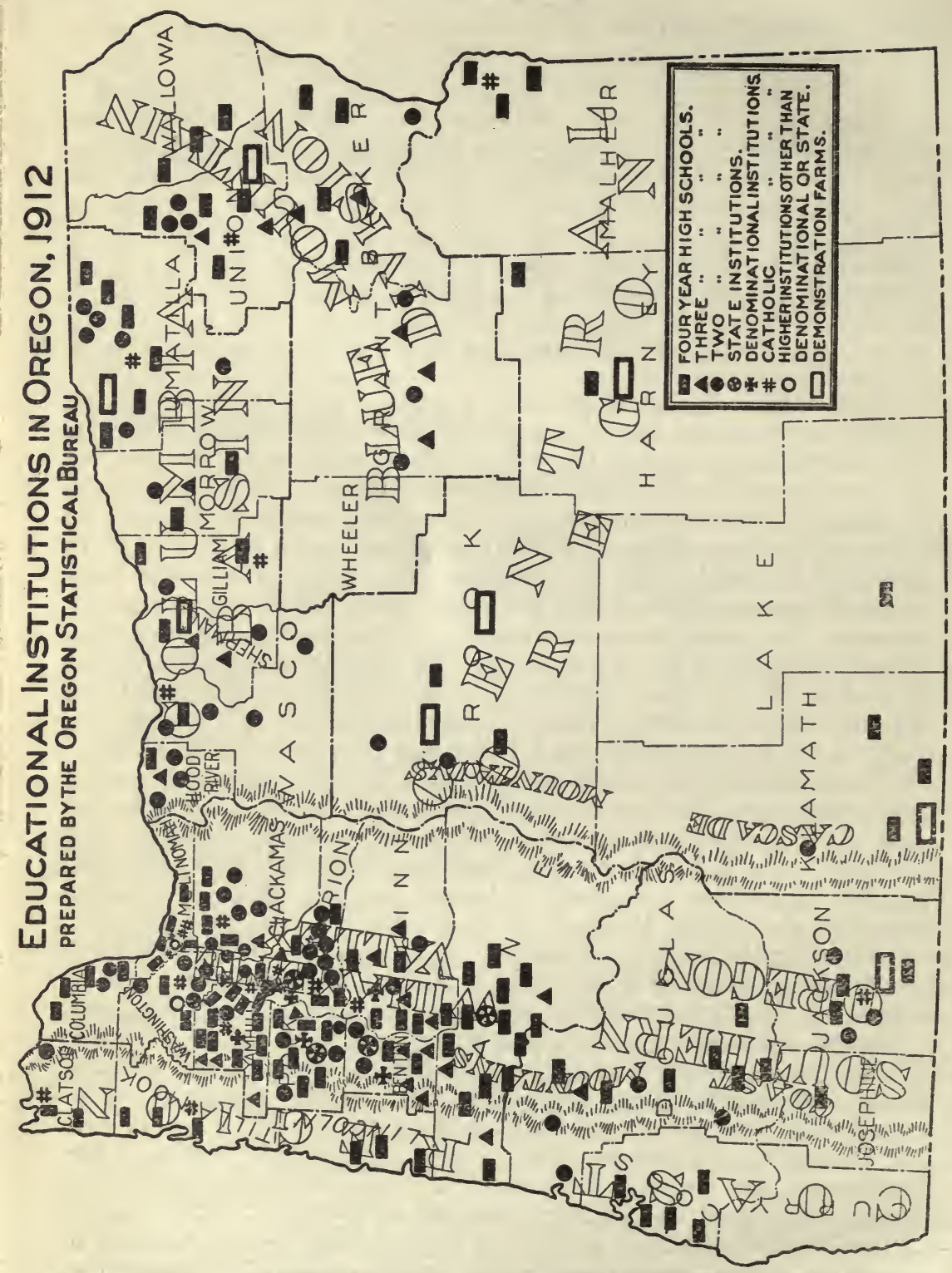

Oregon's educational system offers an opportunity for every class, from the kindergarten to the education that stands for culture. Co-ordinate with the system of the three R's are the manual training and trade schools of the larger cities. The crowning feature of its industrial education is the Oregon Agricultural College. It stands for the highest development of the rich agricultural resources of the state through an educated hand and head. It offers educational opportunities to all workers. 
them with almost any brand they like to name. In fact, I think one would have to look around a good deal in order to find a section of country more thickly dotted with denominational colleges than is the Willamette Valley. A study of the following chart of educational Institutions in Oregon will make this clear, besides setting forth a bird's eye view of educational conditions throughout the state.

\section{The Influence of The Church.}

Turning again to the table, "Social Statistics" (B) (table, page 117), we notice the astounding fact that of 794 reports on the influence of the rural church in Oregon, 663 , or 86 per cent claim that the church is gaining ground in its influence upon rural life.

There are several reasons for this favorable report. In the first place, rural Oregon has never been subjected to anything like the amount of duplication of churches which disgraces the very name of Christianity in many of the older states. In the second place, there are few states where the average intelligence is higher. People in Oregon are more prone to subject their convictions to the scrutiny of reason, rather than take them ready made from others. Hence, the religious crank with his manifold brands of salvation, like the political spellbinder, the eloquent mouthpiece of the machine, has never been taken so seriously in Oregon as in other states.

In fact, we believe there is enough independence and intelligence in Oregon to blaze the way for a new rural church. It shall be a church in which service shall count instead of dogma, a church which shall find in living problems an inspiration and a dynamic force which stories of a dead past have long ceased to supply.

Some beginnings of the new era are already to be discerned. One of the most notable is the federation of three of the old time denominations of the small town of Independence in a single church corporation. Three weak competing churches united their forces, and hired a good man to be their spiritual leader in a capacity which is impossible for any paid advocate of a sect or creed. What Independence has accomplished other rural communities can also do. Few other movements could accomplish more for rural life than church federation.

SOCIAL STATISTICS-C.

\begin{tabular}{|c|c|c|c|c|c|c|c|c|c|c|c|c|}
\hline \multirow[t]{2}{*}{ Division. } & \multicolumn{3}{|c|}{$\begin{array}{l}\text { Societies for } \\
\text { Women. }\end{array}$} & \multicolumn{3}{|c|}{$\begin{array}{c}\text { Organizations for } \\
\text { Material } \\
\text { Improvement. }\end{array}$} & \multicolumn{3}{|c|}{$\begin{array}{l}\text { Associations for } \\
\text { Social } \\
\text { Entertainment. }\end{array}$} & \multicolumn{3}{|c|}{$\begin{array}{c}\text { Societies for } \\
\text { Social } \\
\text { Intercourse. }\end{array}$} \\
\hline & $\begin{array}{c}\text { No. of } \\
\text { Reports. }\end{array}$ & Yes & No & $\begin{array}{l}\text { No. of } \\
\text { Reports. }\end{array}$ & Yes & No & $\begin{array}{l}\text { No. of } \\
\text { Reports. }\end{array}$ & Yes & No & $\begin{array}{l}\text { No. of } \\
\text { Reports. }\end{array}$ & Yes & No \\
\hline $\begin{array}{l}\text { Coast Division... } \\
\text { Southern Oregon. } \\
\text { Willamette Valley } \\
\text { Columbia Basin.. } \\
\text { Blue Mountain... } \\
\text { Central Oregon... }\end{array}$ & $\begin{array}{l}134 \\
200 \\
468 \\
215 \\
168 \\
172\end{array}$ & $\begin{array}{r}35 \\
79 \\
307 \\
109 \\
60 \\
65\end{array}$ & \begin{tabular}{r|}
99 \\
121 \\
161 \\
106 \\
108 \\
107
\end{tabular} & $\begin{array}{l}165 \\
201 \\
493 \\
222 \\
182 \\
142\end{array}$ & $\begin{array}{r}105 \\
127 \\
354 \\
175 \\
87 \\
56\end{array}$ & $\begin{array}{r}60 \\
74 \\
139 \\
47 \\
95 \\
86\end{array}$ & $\begin{array}{r}88 \\
92 \\
335 \\
156 \\
58 \\
179\end{array}$ & $\begin{array}{r}62 \\
68 \\
276 \\
93 \\
45 \\
108\end{array}$ & $\begin{array}{l}26 \\
24 \\
59 \\
63 \\
13 \\
71\end{array}$ & $\begin{array}{r}83 \\
50 \\
335 \\
156 \\
63 \\
169\end{array}$ & \begin{tabular}{r|}
67 \\
38 \\
284 \\
92 \\
52 \\
114
\end{tabular} & $\begin{array}{l}16 \\
12 \\
51 \\
64 \\
11 \\
55\end{array}$ \\
\hline State............. & 1357 & 655 & 702 & 1405 & 904 & 501 & 908 & 652 & 256 & 956 & 647 & 207 \\
\hline
\end{tabular}




\section{Other Rural Organizations.}

Besides the church with its women's auxiliaries, and other subsidiary organizations, Oregon has quite a variety of clubs, societies, and fraternities, which profess to be grappling with the problems of the farmer.

In the table, "Social Statistics" (B), (page 117), we have condensed a summary of the chief facts concerning such organizations. In the column headed "yes" are indicated the families whose members are affiliated with some such association; while under "no" we have the number of families where no such affiliation exists. An analysis of the figures shows that a large percentage of the families are united with associations for material and mental improvement or social intercourse.

The dominant rural organizations are the Grange and The Farmer's Educational and Co-operative Union. The former claims upwards of 10,000 members, and the latter about 5,000 members in the state. Both claim economic functions as well as educational activities. In practice, however, the Grange specializes more in educational programs, and meetings for social intercourse; while the Union is predominantly a business organization. Both associations admit women to membership as well as men; and through their harmonious legislative policy, they are coming to be a power in advancing the rural interests of the state.

Without further description of farmer's organizations, we may close by warning farmers against division in their ranks. If we are to have a strong, progressive rural policy in Oregon, we must have a harmoniously organized rural population. They must stand together as one man for better farming, better business, better rural education.

\section{Summary.}

In Oregon, then, we find conditions varying all the way from the $\log$ hut of the pioneer to the modern farm dwelling which would grace the best residence districts of our cities. Everywhere, we find a sturdy population, above the average in intelligence, and strongly supporting American standards of life and the best American ideals.

In the furtherance of those ideals, we find them progressive to a degree. Oregon has woman suffrage, and is the home of direct legislation, the initiative, referendum and recall. The progressive spirit of her citizens is further shown in the readiness of Oregon farmers to unite and work together for their mutual improvement, politically, socially, economically, and intellectually.

Finally, Oregon's population does not lack elbow room in any sense of the word. They have as yet scarcely explored their wonderful natural resources; and they have a climate which neither benumbs by its cold, ennervates by its heat, nor terrifies by earthquake, storm, or flood. 


\title{
THE OREGON RURAL HOME.
}

\author{
By Henrietta W. Calvin, \\ Dean School of Domestic Science and Art.
}

7 $\mathrm{T}$ the time at which this preliminary Agricultural Survey was started it was not intended to include any special data in regard to the Oregon rural home. Therefore our statistics are rather meager and much of that which will herein follow is based upon observation personally made in the various parts of the state rather than on the statistics.

There are a number of conditions essential to the contentment and welfare in rural homes; comfortable and sanitary houses equipped as far as possible with modern conveniences; possibilities for the women of the household to meet other women who are similarly located; organizations for social and intellectual betterment; opportunities for the members of the household to be able to converse and receive information over telephones and daily receive news from the outside world; possibilities for the children to acquire a good fundamental education without leaving home and for all members of the family to have the opportunity of social intercourse with their families; and that, arrangements by which the manual labor be so provided for that no member of the household shall be exhausted physically or so constantly occupied that there is not time for intellectual or social improvement.

The country houses represent very naturally three stages in their evolution. The first dwelling of the new settler, in any community, is of the smallest and most temporary type that will protect him and his family from the elements. It is usually quickly constructed, located near to the road and often the proximity to a known water supply is the most essential matter to be considered. The first home is not always convenient but often represents both hope and happiness because it is recognized as a symbol of the first beginning of a new life which offers great opportunities.

The average cost of dwelling, as exhibited in chart in financial report of this volume, is but $\$ 533.00$ in Central Oregon. This portion of the state is of the most recent development and these homes are often in their first stages of evolution. There is another reason for the low cost of these dwellings which is that they are constructed from local building materials which can be purchased cheaply or prepared on the homestead.

After a few years, more rooms are added to the first small structure and there is a gradual betterment and general improvement of surroundings. This enlarged country home is comfortable. Though it may not be particularly convenient it often meets the more pressing needs of the family and many of the really important events of the family take place within its walls. It so thoroughly represents to all of the family the real home that it is not strange that this second 
dwelling remains long after the land owner is financially able to replace it by a better type of dwelling. In the interim between the second form of farm home and the permanent one there is a marked improvement in the barns, granaries, machine sheds and other farm structures so that the houses seem over-shadowed by the fine barns.

By the exhibit before referred to, it will be seen that the average value of the rural dwelling is from $\$ 1,204.00$ to $\$ 1,549.00$. The cost of the dwelling increasing slightly with the increased acreage of of the homestead. Those homes are in the second stage of development.

In many parts of Oregon this second form of dwelling predominates because the state is still new, but in all localities the third type, the permanent dwelling, is making its appearance.

The $\$ 3,000.00$ to $\$ 5,000.00$ farm dwelling is a not infrequent sight in all parts of the state, especially in those portions which have been longest settled.

In no other part of the country can modern, convenient and upto-date houses be more cheaply erected. There is a large part of the state of so mild a climate that the houses do not have to be warmly constructed. In most parts of the Willamette Valley and Southern Oregon districts, it is possible to introduce running water through the house by the mere diversion of mountain streams. It is even more easy in the homes of the Coast region than for those in any other part of the state to thus introduce water through the house. In many parts of Central Oregon the water rises within four feet of the top of the ground, and where it is necessary in such localities to elevate the water, this elevation can be done by windmills which method is neither difficult nor excessively expensive. Special emphasis is here placed on introducing the essential city conveniences in the rural house, because it is an accepted fact, that often families leave the farm and take up urban residences because of the desire of the women of the household for the same household comforts which are obtainable for her city sister. With the abundance of water power in all parts of Oregon, it is but a question of a few years when cooperative organizations of thefarmers will utilize this power for the introduction of electricity in their homes. With the well constructed houses which are becoming increasingly numerous in all parts of the state, with these houses supplied with running water, baths, furnaces, and good artificial light, the first essential condition of the satisfactory rural home will have been met.

It will be observed that from the statistics as set forth in the following portion of this report, $25 \%$ of the women of the Coast division belong to women's clubs or associations for women, $39 \%$ of those in Southern Oregon and $63 \%$ of those in the Willamette Valley have similar affiliations. Fifty per cent of the women in the Columbia Basin, $38 \%$ in the Blue Mountain region, 37\% in Central Oregon, belong to women's organizations, while a much higher percentage belong to societies in which both men and women take part. The 
newness of Central Oregon and the large size of the ranches account in no small degree for the comparatively low percentage of women who are able to belong to social organizations. With the rapid increase of settlement in that region, it is predicted that within a few years these organizations will multiply rapidly. Many more women could belong to these clubs if their interest were once awakened. Women are naturally conservative and they permit family duties to so engross them that they may neglect neighborly associations. That $75 \%$ of all the women thus represented in these statistics have access to libraries, that $61 \%$ of those families are accessible to high schools, while $56 \%$ receive daily deliveries of mail, and $80 \%$ have telephones, all goes to show that the Oregon homes are not isolated from the world.

There are almost no statistics indicating the type of occupation in these houses. It is safe to conclude that much of the poultry raising is done by women and that there is much farm dairying practiced. The making of the butter on the farm is always a preliminary condition to the establishment of creameries, so that within a few years the farm woman will be relieved of the butter making, and the cream will be handled in local creameries or sent to the cities.

Poultry raising is generally proving profitable and men are beginning to appreciate this "farm crop." Soon the burden of the care of the poultry will in part at least, pass to the men on the farm and the women be relieved of much of this labor.

That the families living on large farms live better, is to be doubted, though the table elsewhere given might be taken to indicate this. The higher expenses of the family on the homestead is accounted for in one of several ways. The small farm often produces much of its own food supplies while the large ranches are often specialized to the production of stock. It is possible also that the owner of the large ranch more often entertains outsiders than does the owner of the small homestead.

The charts indicate that but an average of $\$ 50.00$ per family was spent for recreation, medicine, etc. It is probable that the greater portion of this was expended for other purposes than medicine. The climatic conditions are so favorable for health that it would not be expected that much would be devoted to medical attendance.

It is so easy for families to spend delightful vacations in the mountains or by the sea shore that it is not strange that every one does some inexpensive camping each year.

The conclusion is that the conditions are all favorable for satisfactory rural homes being established in all parts of Oregon.

To find out what success the ordinary farmer has attained, study these statistics. What the ordinary man has done on an average, is a safe guide as to what the average, industrious newcomer can accomplish. Here are the unvarnished facts. Scrutinize them closely. 


\section{TYPICAL SUCCESSFUL FARMS.}

By E. B. Lemon,

Assistant Statistician.

\section{$\mathfrak{C}$}

HE State of Oregon contains 96,699 square miles or approximately 62,000,000 acres. It embraces a larger territory than the combined area of the six New England states, Maryland and New Jersey. The two largest of its thirty-four counties cover an area equal to the States of Maryland and Vermont, while its smallest county is nearly one-half as large as Rhode Island. According to the Census of 1910, the average size Oregon farm is 255 acres, although the state has a single farm one-fourth the area of Rhode Island and a large number ranging in size from one-thirtieth to one-fifteenth of that entire state.

In this vast area within the Oregon boundary, physical and climatic conditions vary considerably. To describe farms typical of all these divisions and conditions would require a book of itself. However, as indicated on page 7 , the state naturally falls into six divisions as far as topography is concerned. Even in these divisions conditions are diversified, but it is possible to find a large number of farms which are typical of the general characteristics of numerous successful farms of the respective localities. It is, therefore, the purpose of this article to briefly describe one farm of this type in each of the six divisions mentioned above.

The Coast Division, which extends across the entire western portion of the state, is devoted largely to the dairying industry. General farming is engaged in to some extent, and farms devoted to stock raising exclusively are not uncommon. Some localities are also giving considerable attention to fruit growing. The latter industries, however, give way to the first mentioned in importance, for the coast region is admirably adapted to dairying.

\section{Coast Division.}

The survey of the Coast Division indicates that the leading farms contain about 160 acres. In all, 176 farms were visited and of this number 56 contain between 81 and 160 acres and 55 between 161 and 320 acres. It is also interesting to note that it is these farms which are paying the highest rate of interest on the capital invested. This being the case, and also since dairying is the leading industry in the Coast Region, farm Number Three will be described as being typical of this division.

Farm Number Three contains 150 acres of which 50 are in cultivation, 25 in meadow, and 75 in pasture. The pasture is mostly billy, while the portion in cultivation is bottom land, the soil being clay loam. The average market value of this land, including a $\$ 1,200$ dwelling and an equal amount invested in other buildings, was estimated by the owner to be $\$ 175$ an acre, making a total real estate investment of $\$ 26,250$. However, the principal source of profit is a 
herd of 23 grade cows, headed by a pure bred Jersey sire. During the year covered by the survey the milk produced by this herd returned $\$ 2,070$. This is a greater return per cow than the average of the community, but is doubtless due to the fact that the product is manufactured into cheese on the farm and shipped direct to the Portland markets. The male calves were killed as soon as dropped, but eleven heifers were added to the herd, and at the end of the year were valued at $\$ 30$ each, or a total of $\$ 330$. This increased the gross income to $\$ 2,400$ from a herd valued at $\$ 1,685$.

Fifteen head of other cattle were disposed of for $\$ 750$. Fifteen hogs were also marketed for which $\$ 230$ was received. These hogs were raised and fattened almost entirely on pasture, artichokes and by-products of the dairy, only about $\$ 40$ worth of other feed being used in preparing them for the market.

Practically all the field crops raised are used for feed. In the year which we are considering, 25 acres of clover meadow yielded an average of two and one-half tons per acre; three acres of oat hay yielded three and one-half tons per acre; the two acres planted to kale returned forty tons, and one-half acre of potatoes yielded 100 bushels, of which 50 bushels were marketed at the rate of one and one-fourth cents per pound. The average yield of potatoes in this section, however, is about 300 bushels per acre. An interesting experiment is being carried on with artichokes and the results obtained thus far indicate that they will prove most successful. Although the acreage planted has been small, the yield has been exceptionally heavy, and good results have been obtained by feeding the green stocks to the dairy cows and then letting the hogs harvest the tubers.

The home garden supplies the family with all of the vegetables desired, but no attempt is made to grow any for the market. A few small fruits are grown quite successfully, but very little attention is given to this phase of the farm. The same is true of the poultry department. About thirty Plymouth Rock hens are kept, all produce being consumed by the family.

After considering the sources of profit and the results, it is now time to turn our attention to the cost of production. Two men, two horses, and implements and machinery valued at $\$ 1,000$ are required to operate Farm Number Three. The capital invested, including land and buildings, $\$ 26,250$, live stock $\$ 2,519$, and machinery $\$ 1,000$, is $\$ 29,769$. As would naturally be expected, the largest item of expense is for hired labor, $\$ 500$ being required for this purpose. Other expenditures in order of importance are as follows: Household $\$ 420$; taxes $\$ 135$; feed purchased $\$ 130$; and miscellaneous items $\$ 80$; making the total cost of production, irrespective of family labor, $\$ 1,265$. Subtracting this amount from $\$ 3,087.50$, the total receipts, a net balance of $\$ 1,822.50$ remains, or in other words, a return of over six per cent, on the capital invested.

Summarizing these results, then, we find that in 1911, Farm Number Three represented an invested capital of $\$ 26,250$; gross 
receipts $\$ 3,087.50$; total expenditures $\$ 1,265.00$; family income $\$ 1,822.50$, or a return of 6.1 per cent on the capital invested.

\section{Willamette Valley.}

The Willamette Valley presents conditions even more diversified, for nearly every agricultural industry of importance in the state can be found to some extent, at least, in this division. Although there is an apparent growing tendency to specialize along certain lines, the general farms still predominate. These vary in size from five to one thousand acres, and a few are even larger than the latter class. However, the figures obtained during the survey indicate that the average size valley farm comprises between two hundred and three hundred acres.

Farm Number Ten, located in Benton County, is typical of the successful Willamette Valley farms. It represents an investment of $\$ 17,285$ which comprises 250 acres of land valued at $\$ 50$ per acre; live stock valued at $\$ 3,785$, and implements and machinery $\$ 1,000$. The land value includes a $\$ 700$ dwelling and $\$ 600$ in other buildings. The soil is sandy loam with some gravel, and 160 acres are in cultivation while the balance affords excellent pasture.

Field crops, dairy products, live stock, and poultry were the various sources of profit in 1911. Eighty acres of spring wheat yielded 17 bushels per acre and forty acres of oats yielded 30 bushels per acre. Both of these crops, however, were probably at least 25 per cent below the average yearly yield. Twelve hundred bushels of wheat were marketed at 75 cents per bushel, and 900 bushels of oats at 40 cents per bushel. One acre of potatoes yielded 200 bushels, and of this amount $\$ 115$ worth were marketed, making the total sales from field crops $\$ 1,363$. The crops consumed on the place included 40 tons of vetch hay grown on 20 acres; 21 tons of grain hay from 14 acres, and one acre of kale.

The farm dairy consists of 13 grade Jersey cows valued at $\$ 50$ each. The sum of six hundred dollars was received for cream sold at an average price of 27 cents per pound. Nine veal calves netted $\$ 81$.

Besides the dairy animals, the farm is stocked with seven head of work horses, seven colts under three years old, 150 head of sheep, 130 goats and 30 swine. One four-year-old horse was sold for $\$ 225$ and two cows for $\$ 45$ each. No other animal husbandry sales were made during the year.

The poultry department is conducted principally for the family use, but nevertheless the produce returns are usually a noticeable item in the profit column. It was $\$ 175$ for the year we are considering. About 150 hens are kept, these being a mixed breed, the Rhode Island Red strain predominating.

Nine stands of bees produced a sufficient amount of honey for home use but none was marketed. The home orchard and garden receives very little attention from a commercial point of view although practically all of the fruit and vegetables desired by the family are 
raised successfully. A two-year orchard consisting of 100 peach trees, 50 pear trees and nine cherry trees is thriving exceptionally well.

The total expenditures for the year were $\$ 1,310.70$, the largest single item being $\$ 500$ for the household, which is above the average, but we must take into consideration that there are eight members of this family. The cost of hired labor was $\$ 250$. Two boys attending high school are available during the busy seasons, consequently the labor cost rarely exceeds the amount stated. All other expenditures can be considered under three heads; namely, threshing and twine, $\$ 187$; taxes, $\$ 185$, and miscellaneous, $\$ 188.70$.

Since the gross income amounted to $\$ 2,534.00$, and the total expenses to $\$ 1,310.70$, the net family income was $\$ 1,223.30$, or an amount equal to a return of slightly over seven per cent. on the capital investment- $\$ 17,285$.

\section{Southern Oregon Division.}

The Southern Oregon Division embraces the Umpqua and Rogue River Valleys and numerous smaller tributaries, famous for their production of fruit, vegetables, and other agricultural products. Like the Willamette Valley, the Southern Oregon Division presents conditions extremely diversified, and is adapted to almost every phase of agricultural development. However, the rich and fertile valleys have attracted the attention of scores of horticulturists and as a result fruit raising has become a paramount industry.

The survey of this district covered every locality, and farms of all classes are included in the results. Reports were secured from 231 farms and of this number, 38 contain less than 20 acres; 59 between 21 and 80 acres; 45 between 81 and 160 acres; 46 varied from 161 to 320 acres; and 43 contained over 320 acres. The general tendency seems to favor the smaller farms. Most especially is this true of the more developed fruit and garden districts. According to the figures obtained, the smaller farms are also paying a considerably larger rate of profit on the capital invested.

A good example of the smaller class is Farm Number Forty-five in Jackson County. This farm contains 13 acres which is the state average for farms under 20 acres. It is devoted exclusively to the growing of pears, and in 1911 the gross sales reached the sum of $\$ 6,909$. Others are giving attention to apples or other kind or kinds of fruit with like results. The present owner purchased Farm Number Forty-five in 1909 at $\$ 2,000$ per acre. The improvements at that time included a $\$ 5,000$ dwelling and other buildings valued at $\$ 1,000$.

The soil is a medium sticky black loam and averages about six feet to gravel. It is all under irrigation, the water for this purpose being obtained from a large well by means of an electric pump. The orchard occupies twelve of the thirteen acres and consists of 895 trees, representing three different varieties. Ninety of these trees are the Bartletts, 490 are Howells, and 315 D'Anjous. The total 
yield in 1911 was 3,000 boxes or an average of 3.35 boxes per tree. This crop was marketed at an average of $\$ 2.30$ per box; a return of $\$ 7.72$ per tree, or $\$ 576$ per acre.

The home garden supplies the family, but the pear crop constitutes the only source of profit. One cow, three hogs, and eight stands of bees are kept, the produce being utilized entirely for home consumption.

Two men and two teams are required to operate this farm. Only one team, however, is necessary, except for a short time during the busy season. The value of all live stock kept was fixed at $\$ 934$. The implements and machinery used, including a gas spray and an electric pump, is approximately $\$ 1,000$. The total capital invested then is $\$ 33,934$. The total expenditures for 1911 were $\$ 3,853.22$, which, when taken from the receipts, left a family income of $\$ 3,056$. This is a payment of nine per cent on the capital invested.

As all of the work in 1911 was done by hired labor, that account heads the list of expenditures, and including the cost of picking, reached the sum of $\$ 1,500$. The crop was packed and marketed by a local association, the cost of preparing for market being 27 cents per box, amounting to $\$ 810$; the marketing commission was eight per cent, or $\$ 552.72$.

As no feed of any kind is raised it was necessary to purchase both hay and grain at a cost of $\$ 328.50$. Other expenses were as follows: boxes $\$ 125$; household $\$ 497$; and misccllaneous items $\$ 40$.

\section{Columbia Basin.}

The remaining three divisions of the state comprise what is known as Eastern Oregon, and aggregate about 60,000 square miles. This region consists largely of high tablelands and rolling plains, vastly different from those sections of Oregon in which the farms already described are located. The farms of Eastern Oregon are, therefore, also, of an entirely different character, and must be described from a different point of view. Wheat and stock raising are the principal industries and the farms, as a general rule, are unusually large.

The northern portion of this vast area bordering on the Columbia River is principally rolling hills traversed by a few narrow valleys and constitutes the Columbia Basin. Some of these valleys are adapted to fruit growing, but the larger area is a stock and grain district. There are two notable exceptions, however; the famous Hood River Valley and the Freewater-Milton district, known the country over for their fruit production. The former is located in the county whose name it bears, and the latter is in Umatilla County. A few other localities are also coming into prominence as fruit sections. Of the 309 farms visited in the Columbia Basin, considerably over half of that number fall within the division of over 320 acres and average 2,137 acres to the farm. There are, however, many farms which are much smaller but just as successful, although at the present time the larger ones are most typical of the division. 
Farm Number Thirty-five, in Gilliam County, is a fair average of this class. From a financial point of view this farm may briefly be described as follows: Capital invested $\$ 41,740$; gross income $\$ 7,718$; expenditures $\$ 3,824$; family income $\$ 3,894$; and rate of profit 9.3 per cent. This rate is slightly above the state average, but is nearer the average rate of the division.

Farm Number Thirty-five contains 1,680 acres. Of this amount 480 are rented and, therefore, are not counted in the capital invested. The average value is $\$ 30$ per acre. The soil of about 1,200 acres is deep and of the silt loam type. The balance of the acreage is more or less rocky and is not under cultivation but affords very good pasture. The buildings are valued at $\$ 1,000$ and an equal amount is invested in implements and machinery. Three men and eighteen horses are required to operate this farm.

Throughout the Columbia Basin it is customary to summer-fallow cultivated land every other year, consequently only about one-half of the acreage is sown in any one season. In the year of the survey 685 acres of Farm Number Thirty-five were in crop. Eighty-five acres of grain hay produced one and one-half tons per acre, and 600 acres of fall wheat yielded 18 bushels per acre. Of the total yield, 10,800 bushels, 9,640 were marketed at 70 cents per bushel, returning $\$ 6,748.00$. There is no orchard on the place, but a small garden is cultivated for home use. The animal husbandry department was the other leading source of profit, $\$ 920$ being the amount of sales. Four grade Shire horses were sold for $\$ 760$; one cow and two calves for $\$ 60$, and four Duroc Jersey hogs for $\$ 100$. At the time this inventory was taken, the farm was stocked with 21 head of horses, 11 mule colts under three years old, two cows, one calf, and 85 hogs, the total value being $\$ 3,740$. Fifty dollars were received from miscellaneous sales of poultry. Both chickens and turkeys are kept but mainly for home consumption.

The \$3,\$24 expended may be classified as follows: hired labor $\$ 1,000$; rent $\$ 600$; threshing, sacks and twine $\$ 1,076$; household $\$ 625$; taxes $\$ 145$, and miscellaneous items $\$ 382$.

\section{Blue Mountain Division.}

The Blue Mountain Division is the most diversified section of Eastern Oregon, but owing to inadequate transportation facilities, many localities remain undeveloped and stock raising is the principal industry. There are exceptions to this general condition, however. Especially is this true of Union and Baker Counties, where fruit growing and dairying are receiving considerable attention. Nevertheless, stock raising still ranks first, in order of importance, in the division as a whole, with sheep and cattle farms leading in numbers.

Farm Number Sixteen, in Grant County, is typical of the successful cattle ranches. It represents an investment of nearly $\$ 40,000$, of which $\$ 22,800$ is real estate and machinery, and $\$ 17,100$ the value of live stock. The farm contains 500 acres and in addition to this 1,280 acres of pasture land are rented. $\_$About 250 acres are culti- 
vated and under irrigation. This produces all of the hay and grain required for winter feed, and with the number of stock above mentioned, sales returned $\$ 1,340$. About 180 acres is wild hay which yields an average of approximately 400 tons yearly. Wheat, oats, barley and rye are raised on the remainder of the cultivated land and yield exceptionally well.

The receipts from cattle sales for 1911 netted $\$ 4,600$ for 105 head. All cattle raised are grade Herefords and Durhams, but pure bred sires are always kept. At the time this farm was visited, it was stocked with 100 head of beef cattle, 300 head of stock cattle, 20 head of horses, and 10 swine. No special dairy cows are kept, but enough stock cows are milked to supply the farm. Poultry is also kept only for home use.

A small orchard consisting of apples, pears, plums, and cherries produces well during ordinary seasons, but cannot be depended upon in this particular locality. No fruit is marketed.

Five men and ten horses are necessary to handle the ordinary farm work. The cost of hired labor for 1911 was $\$ 1,500$. This item would be greater if it were not for the fact that two men are operating this farm. Other expenditures were household $\$ 600$; rent $\$ 200$; taxes $\$ 300$; and miscellaneous items $\$ 150$; a total of $\$ 2,750$.

Summarizing these results we find a capital of $\$ 39,900$; gross income $\$ 5,940$; expenditures, $\$ 2,750$; family income $\$ 3,190$; rate of profit 8 per cent.

\section{Central Oregon.}

Five of the largest counties in the state, or an area of 41,513 square miles, comprise the Central Oregon Division. This vast plateau region is still comparatively undeveloped. Until the intervention of railroad activities only recently, these thousands of acres were partially utilized by stockmen for grazing purposes. There are still many large farms, several containing as much as 50,000 acres. But a change is rapidly taking place and already many small diversified farms are thriving. Such a farm is Number Seven, located in Crook County, and this is the class we must now describe as typical of the division instead of one of the extensive stock farms which formerly predominated.

Five years ago the owner of Farm Number Seven acquired an eighty-acre tract and immediately began to develop a diversified farm. Later an additional 80 -acre tract was rented and he is now controlling 160 acres. About 140 acres are in cultivation. The soil is silt loam and averages about ten feet to rock or gravel. Four hundred dollars have been invested in improvements and the place is now valued at $\$ 60$ per acre.

Alfalfa is the leading field crop, 60 acres yielding an average of three and one-half tons per acre. Ten tons were sold at $\$ 10$ per ton. Fifteen tons of grain hay were marketed at $\$ 8.50$ per ton. The balance of these crops was used for feed. 
Thus far dairying has been the principal source of profit. The dairy herd consists of 12 grade Jersey cows valued at $\$ 100$ each, and is headed by a pure bred Jersey sire. The produce from this herd returned $\$ 762$. One cow was sold for $\$ 75$; five veal calves and five yearlings netted $\$ 305$; and a horse was sold for $\$ 100$, making the total of live stock sales $\$ 480$.

Geese, ducks, and Brown Leghorn chickens were found in the poultry department. During the year two dozen chickens were sold for 50 cents each; 40 ducks at 75 cents each; and 720 dozen eggs at an average of 30 cents per dozen; aggregating $\$ 250$ for this department.

Two hundred dollars were expended for hired labor during the hay harvest, but the amount was returned by work with teams done for others during less busy seasons. The household expenses amounted to $\$ 875.00$. There are six members of the family, four under fifteen years of age. Taxes amounted to $\$ 62.50$ and miscellaneous items to $\$ 135.50$.

The inventory showed the following resources; real estate, $\$ 4,800$; implements and machinery, $\$ 500$; live stock, including 15 head of horses, 17 head of cattle, and 6 swine, valued at $\$ 3,215$, and $\$ 500$ in cash for operating expenses. The total capital invested is then $\$ 9,015$. The gross receipts, including $\$ 200$ labor for others were $\$ 1,919.00$. The total expenditures, including $\$ 200$ for hired labor, were $\$ 1,273.00$. This leaves a family income of $\$ 646$, or an amount equal to 7.16 per cent on the capital invested.

The 1910 Census shows that there were 45,502 farms in Oregon on that date. There are more now. The farms described above are by no means representative of this number nor do they represent all of the agricultural conditions and industries of the state. There are many farms paying a much larger rate of interest, and of course there are others, which are not so successfully managed, paying much less. They are, however, typical of certain general farms and industries of their respective localities.

\section{GOOD DEMAND FOR FARM IABOR}

The laboring man can readily get a start in Oregon if he is willing to go into the country. There, high wages are paid for milkers, ranch hands and farm workers. The supply of labor in the country districts does not meet the demand. The wages paid for farm work are practically all clear gain, and if saved and put into a piece of land will soon enable the laborer to become a home owner and independent citizen. 


\section{INDEX.}

Adobo Solls-Composition and description of ............................... 46-49

\section{Agriculturo-}

Agricultural Statistics-

Average Farm Acreage, Price, Yield and Value each of Chief Crops in Different Regions of Oregon-as Grown on Representative Farms-1911.

Climate, Soil, Topography, Transportation Facilities, Market Conditions, Price of Land, in Relation to..

Counties Leading in Production Field Crnps..

Farming Conditions in Oregon(Miscellaneous Data)...

Farm Crops of Öregon................... $52-54$ Oregon and Other States............... 53-5 Oregon Crop Production by Regions........ 55 Oregon Yields and Prices Compared with Leading States.

Farming in Oregon-Types of ............... 33

Field Crops Adopted to Different Districts:

For Cash Field Crops.

For Dairy Cows...

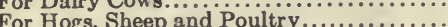

Field Crops not Grown in Oregon

Hay and Forage, by Divisions. $1909 \ldots \ldots \ldots \ldots .55$

Hop Production-Oregon Compared with Other States.

Irrigation Statistics.................... 44

Miscellaneous Crops. Grown Only in Certain Regions (Table).

Opportunities of in Öregon (Ärticle).............13-14

Present Occupation of Lands..............43-44

Production and Acreage of Chief Field Crops,

by Divisions. for 1909 .

Products in Oregon in 1912

Rotation and Cropping Systems of Oregon. .62-fi3

Selecting a Farm in Oregon................ 35

Soils of Oregon.......................46-47 Chief Soil Types....................... 46

Composition Silt Loams.................46-47

Composition Sandy Loams............... 46-48

Composition Marsh Soils...............46-49

Composition Adobe Soils.............46-49

Composition Granitic Soils..............46-50

Composition Pumice Soils................46-51

Composition Alkali Soils. ...........46-51

Survey of Representative Farms-Tabulated 44

Typical Successful Farms-A Summary...124-131

Wealth of in Oregon, Derived from.......... 33

Examining the Prospective purchase.......39-42

Alkali solls - Composition and Description of.46-51

Alfalf a -(See Farm Crops)................52-63

Apiaries-(See Bee Culture).............. 97-99

Apricots-Industry in Oregon . ............ 71-73

Associstions for Social Conditions.......... 120

Average size of Farms.................13-14

Blackborries-Industry in Oregon-(See Fruits and Vegetables)

Barley -(See Farm Crops)................52-63

Blacksmith -Opportunities for Work........ 13

Bee Culture-(Article On)................97-99

Colonies, Number and Value of in State, U.S. Census, 1910.

Distribution of Bees in State (Map)........... 98

Honey, Principal Producing Centers of in State.

Industry Described-by Divisions.............98-99

Statistics on-by Divisions:

Number of Reports; Number of Stands; Bee

Keeping Successful; Colonies Profitable;

Average Price of Honey; Total Sales........ 99

Beef-Distribution of (Map)................ 15

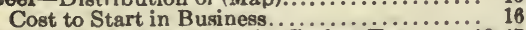

Effects of Feeding Alfalfa, Grains, Etc.........16-17

Feeding-Kind and Amounts of Food .......16-17

Grasing-Rance and Winter................ 16

Industry - how Divided ................... 15
Page

Land Necessary\{ or .................... 16

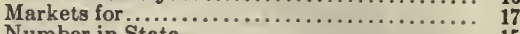

Number in State........................... 15

Pure Bred Industry..................... 16

Statistics On ........................ 15

Bureau of Statistics-

Composed of .......................... 5

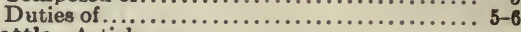

Cattlo-Article on

Beef............................... 15

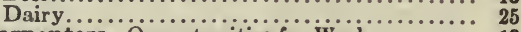

Carpenters - Opportunities for Work............ 13

Cheeso-

Products for 22 factories for year 1912-

Pounds of Milk Received; Pounds of Milk Sold: Amount Received for Cheese Sold: A vverage Price per Pound of Cheese, and Pounds of Cheese per 100 Pounds Milk....

Tillamook County as Producing Center......

Cherries - Industry in Oregon................

By-Products of ........................... 73

State A verage in Prorluction of ................. 71

Chief Types of Soil-Composition and Description of 46-52 Classification of Lands in Stato-Diagram). 112 Clearing Land-A verage Cost of ........... 39

Climate-Article on ........................65-70

As an Attraction.................................

Conditions - in Relation to Poultry Industry

In Relation to Farming. Generally-by Di-

visions..................... 78

Considerations and Changes in Relation to Soils and Farm Crops..................... 38

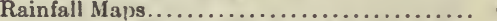

Summary of Normal Climatological Data for

Oregon-by Divisions.................. 6

Temperature and Rainfall Diagram ............. 69

Clover-(See Farm Crons). ...............52-63

Communication and Transportation........ 117

Postal Service and Telephnne............... 119

Railroads and Navigable Streams (Map)...... 118

Contents - Table of ..................... 2

Corn-Total Production and Acreage-by $\mathrm{Di}$ -

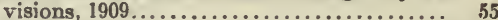

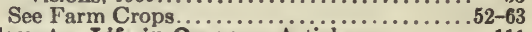

Country Life in Oregon-Article on.......... 111

Moral Tone of People..................... 114

Land Classification-Diagram...................... 112

Oregon-Conditions in as Compared to Other

Countries....................111-112

Social Statistics-

Educational Facilities.................. 120

Postal Service and Telephone................ 119

Rural Organizations....................... 123

Cranberries -Industry in Oregon.............

Dairy Cattle-(See Dairy Industry)............. 25

Dairy Industry - (Article on) ................ 25

Annual Imports of Dairy Products ........... 28

Average Income per Head in State...........27-28

Comparison of Average Income by Counties............................ 28-29 Some Examples................................ 28

Breeds of Dairy Cattle in State.......... 30

Butterfat Prices Paid in Orezon for Years 1009 to 1912 , inclusive, by months..........

Cheese-Industry in Tillamook County-

Statisties, etc..........................

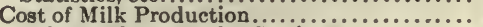

Labor and Wages-by Sections................. 29

Systems of Labor Emplnyment............... 29

Crop Production by Divisions.. ..............52-58

Diversified Dairy Farming - by Diviaions.... 34

Diversified Livestock Farming-Truck and Small Fruits

Farms Reporting Income from Cows............... ${ }_{27}^{34}$

Feeding-Kinds and Cost of Fonds .........29-32

Climate and Relation to Low Food Cost...... 3

Concentrated Foed Stuffs vs. Forage Crops. $3^{2}$ 


\section{INDEX-Continued.}

Kale-Its Value as a Winter Food Page

Long Growing Season and Abundance of Feed Throughout the Winter.

Prices of Feed Stuffs in Oregon as Compared to Middle West States...................

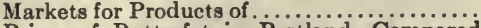

Prices of Butterfat in Portland, Compared to Eastern Cities.

Compared to San Francisco

Number of Cows and Distribution of-by Counties.

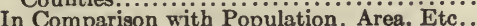

In Comparison with Other States.

Number and Value of Cows and Heifers.....26-27

Comparison of Values-by Sections.........26-27

Market for Surplus Stock................... 32

Number and Kinds of Cream Separators in

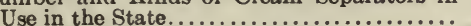

Importance of to Dairy Industry.............. 31

Over-Production-no Danger of ................. 26

Pounds of Milk Received; Pounds of Cheese made: Amount Received for Cheese sold; Average Price per Pound: Pounds of Cheese per 10i Pounds Milk..

Size of Herds and A verage Value per Cowby Sections........................ 27 Typical Successful Farms-a Summary..............

Dewberries-See Fruits and Vegetables....71-85

Diversified Farming-

Diversified Crop and Livestock, by Divisions; Diversified Dairy Farming, by Divisions; Diversified Field Crop Farming. by Divisions: Diversified Livestock Farming, by Divisions ...........................36-37

Editing Committee-Composed of .............. 6

Farm Labor-Gond Demand for............. 131 Farms and Farming-

A_ricultural Opportunities...............13-14

Agricultural Products in Oregon. 1912......... 33

A verage Wages-With and Without Board.... 45

Climate-Article on.................... 65

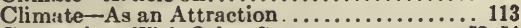

Comparison With Other States...............

Farm Crops of Oregon....................52-54

Financing a Farm .................... $88-107$ Average Capital İnvested....................... 104 Average Family Expenses. . . . . . . . . . . . 105 Average Family Income..............105-106 Average Gross Income...................103-104 Average Rate of Profit................106-107 Average Value of Dwellings............... 102 Average Value of Livestock.............102-103 Average Value Implements and Machinery. 103

Fruit and Vegetable Farming ..............71-83

IIon Produrtion...................... 54

Land Statistics, Total Ärea, etc.

Miscellaneous Data (Statistical); Average Rental; Clearing Cost; Depth of Wells; Average Number Work Horses; Average Acres Irrigated; Average Perrent Using Irrigation; Average Percent Using Rotation; Average Amount Manure Used; Average Crop Sales per Acre.............

Selecting a Farm in Oregon-the Type and

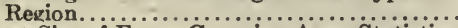

Best Size of Farm, Cropping Area, Statistics,

etc............................. 37

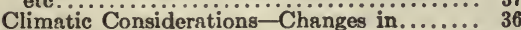

Examining Prosnective Purchaso...........38-42

Getting Started Right.................... 37

Miscellaneous Data on Farming..............44-45

Occupation of Lands. Farming..............4 43

Snils of Oregon .............................. 46

Chief Types of $\ldots \ldots \ldots \ldots \ldots \ldots \ldots \ldots \ldots \ldots \ldots, 46$

Composition of

Statistics on Business Methods............... 108 Different Types of Farms-Percentage of

Examined in the Survey ...............11-98

General Farm Statistics................13-14-14
Page

Value of Farms and Farm Property..... 109

Total Production and Acreage of Chief Field Crops-by Divisions ....................

Typical Successful Farms................124-131 Survey-Agricultural-Cost of ............... 6 Accuracy of Information................ 9

Appropriation for $\ldots \ldots \ldots \ldots \ldots \ldots \ldots \ldots \ldots, 5$

Authority for........................ 5

Classification of Reports....................

Different Types of Farms Examined....... 9

Preparation for....................... 6

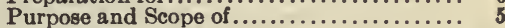

Questions to Farmers.................... 10

Tabulation of Data.................. 6-8

\section{Farm Statistics-}

Average Acreage Operated; Average Depth of

Wells: Average Years on Farm; Number of

Rural Phones; Opportunities for Work; Re-

quired to Operate, Men, Horses; Years Ex-

perience as Farmers....................

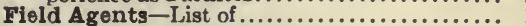

Assignments of Territory to................... 11

Fixpenses and Reports of ................... 10

Instructions to ........................

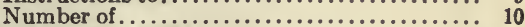

Fruit By-Products................... 73

Fruit Growing - by Divisions.................36-37

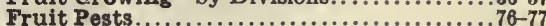

Fruits and Vegetables-Article on.........71-83

Fruit, State Average 1910-1911-Table........ 71

Apples, Pears, Prunes, Cherries............. 72

By-Products of Cherries................ 73

Cranberry Culture..................... 77

District Reports on ........................

Fruit-by Divisions-Statistical and descriptive........................ Industry Combined with Other Crops...... 76 Land Prices in Oregon.................. 75

Loganberries, Peaches and Other Fruits.... 73

Nursery Business...................... 75

Pests and How Combated.................76-77

Thinning, Grading, Packing and Shipping.. 77

Varieties to Plant...................... 76

Vegetables-Statistical and Descriptive......71-83

Typical Successful Farms................124-131

Vegetables (See Fruit and Vegetables)........71-83

Central Oregon Division. .............. 83

Coast Division..................... 77

Columbia Basin Division................ 81

Blue Mountain Division.................. 82

Southern Oregon Division............... 78

Willamette Valley Division................ 79

Geographical Divisions of Stat9............ 8

Goats-

Land Value Increased by Pasturing; Income from Fleece; Rank of Oregon in Quality; Valuable as Land Clearers; Willamette Valley Ideal for.......................... 2

Gooseberries-(See Fruits and Vegetables)..71-85

Grains, Hays. Itc-

Average Acreage, Price, Yield and Value of Each of Chief Field Crops-by Sertions. .57-6í

Counties Leading in Total Production..... 56 Crop Production by Region............... 52 Oregon Yields and Prices of Field Crops Compared with other States..............53-54

Total Production and Acreage of Chief Field Crops-by Divisions (1909)............... 55

Granitic Solls-Composition and Description of............................

Grapes-(See Fruits and Vegetables).........71-85

Greenhouse Business in Oregon.......... 74

Hay and Forage-Total Production and Acreage-by Divisions $-1909 \ldots \ldots \ldots \ldots \ldots \ldots .55$

Rank of Counties in Production of ........... 56

See Farm Crops....................... $52-63$

Honey-(See Bee Culture) . . . . . . . . . . . . . . .97-99

A verage Price of .................... 98 


\section{INDEX-Continuod.}

\section{Hogs-(Swine)}

Average Number of Pigs per Litter......... 17-18

Breeding of Pure Bred Hogs; Growth of; Willamette Valley Excels in.................. 19

Climate and its Effect on Hog Diseases....... 19

Distribution of in State (Map) ............ 17

Forage as a Food Product................ 18

Gains in Flesh on Various Foods.............. 18

Grains Used as Foods...................... 18

Number of in State................... 17

Proportion of Hogs Consumed in Oregon Produced in States.

Results of Food Tests by Oregon Experiment

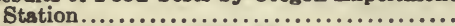

Soope of Industry $(1910-1912) \ldots \ldots \ldots \ldots \ldots \ldots$

Skim Milk as a Food.....................

Statistics on $. . . \ldots \ldots \ldots \ldots \ldots \ldots \ldots \ldots \ldots \ldots, 17$

Wheat and Barley vs. Corn ............... 18

\section{Borses-}

Average Number of per Farm-by Divisions.

Colts as Source of Income................. 20

Cost of Production-Range vs. Feeding........ 20

Distribution of in State.

Draft Horses, most Popular Breeds.........20-21

Mules-(See Mules in Index)

Number and Value of in State............. 19

Number Required to Operate Farms........... 13

Percent of Pure Bred Stallions in Oregon and

United States.

Percent of Pure Bred Draft Stalions in the State............................. 21

Production of Horses in State.............. 20

Production of Draft Horses in State-Growth of Industry $\ldots \ldots \ldots \ldots \ldots \ldots \ldots \ldots \ldots \ldots \ldots, 20$

Pure Bred Horses in State.................. 21

Growth of Popularity of Same............. 21

Statistics on........................ 18 Work Horses-A verage Number of per Farm -by Divisions...................... 4

Immigration Agent, Stato. (Inside Back Cover) Immigration Commission-Personnel of

....................... (Inside Back Cover)

Introduction-Object and Scope of Survey.. 5

Investments in Farms and Improvements.. 14

Irrigation-

A verage Acres Irrigated.

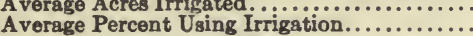

Kale-Its Value as a Forage, Crop-

Districts Where Grown; Average Acreage per

Farm; Price, Yield, and Value per Acre,

Etc.............................61-63

\section{Labor and Wages-}

Average on Farms, with and Without Board. . 45

Clearing Cost-Average-by Divisions........ 44

Farm Labor-Demand for.................... 131

In Dairy Industry . ................... 29

Manure-Average Amount Üsed............... 4

Men-Average Number Roquired to Operate

Farms..............................

Rental-A verage General Farms................

Rotation of Crops-Average Percent Üsingby Divisions.

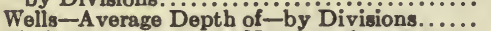

Work Horses-Average Number of per Farm-

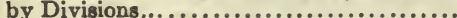
Number Required to Operate Farms.........

\section{Lands-}

Area of-Classified

Soils, Types and Composition of.............. $46-52$

Average Acreage per Farm; A verage Income in Value, 1900-1911; A verage Value Land per per Acre; Cultivated Land; Irrigable Acreage; Land Occupation Dats; Land Occupation Statistics; Now Irrigated; Number of Farms; Tillable Land Uncultivated: Tillable Public Land Open to Entry; Total Land Area ..........................43-44
Letters-Circular to Citizens............... Page

Of Instructions to Agents..................

Iivestock Industry -

Beef Cattlo........................ 15

Alfalfa as a Fattening Product.............. 16

Classification of......................... is

Cost of Starting Industry................. 16

Grain and Hay Feeding................... 16

Map Showing Distribution of ............. 15

Ranging in Eastern Oregon.............. 16

Statistics on Cattle; Percent Increase;

Acres per Head; Value per Acre......... 15

Dairy Cattlo-(See Dairying Industry)..... 30 Breeds of Dairying Cattle.

\section{Goats-}

Mohair-Weight and Value of Fleece....... 24

Rank of State in Number and Quality...... 24

Valuation as Land Clearers................. 24

Western Oregon Conditions Ideal for........ 24

Hogs-

Breeding of Pure Bred Hogs............... 18

Diseases of in Oregon.................... 19

Distribution of in State (Map).............. 17

Foods and Results; Skim Milk, Grains and

Forage Crops .........................

Markets for-Portion of State Consumption

Supplied by Home Products.............

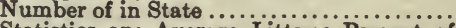

Statistics on; Average Litters; Percent of Two Litters; Percent of One Litter-by Divisions.........................17-18

Borses-

Breeding of-Growing Popularity of Draft Horses............................

Comparion of Conditions and Prices Betweon Eastern and Western Oregon....

Distribution of in State (Map)...............

Methods of Feeding by Districts..............

Number and Value of in State...............

Profits in Colt Raising.......................

Rate of Increase.......................

Stallions-Percentage of Pure Bred in

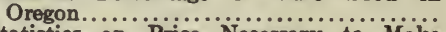

Statistics on-Price Necessary to Make Profit on a 4 -year-old Horse.............. Mulos-

Good Market for Surplus Stock........... 21

Most Popular in Eastern and Central Oregon...........................

\section{Shoep-}

Cost of Feeding Small................... 2

Distribution of in State (Map)..................

Industry Classified by Divisions..............

Oregon Famous as a Breeding Ground......

Pure Bred Sheep Industry...................

Ranging in Eastern Oregon- on Govern-

ment Roserves ....................22-23

Spring Lamb Industry in Western Oregon... 23

Marketing of Spring Lambs.............. 23

Statistics on-Percent Increase; $\mathrm{L}$. Wild Animals; Average Wool Clip; Cost of Wintering; Pasture per Head; Value of Land per Acre; Age Ewes are Sold-by Divisions........................... 21

Wool-Average Clip per Hesd and Cost of Production.......................... Oregon as Compared to Ünited States....

Log anberries - Growing of in Oregon........ 72 State A verage in Production, $1910-1911 . . . . .77$ Maps, Charts, Dlagrams, Etc-(Index)...... Marsh Solls - Composition and Description of.46-49 Masons-Opportunities for Work............. 13 Miscellaneous Data-(Statistical) ........... 41-45 Mules-

Not Popular in Western Oregon............ 21

Production in the State................... 21

Production of in Central Oregon............ 21

Production of in Blue Mountain Section...... 21

Surplus and Exportation of ................ 21 


\section{INDEX-Continued.}

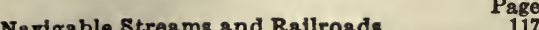
Map of ............................... 118 Occupation of Lands

Land Statistics-Total Area; Cultivated Land; Tillable Land Uncultivated; Tillable Public Land Open to Entry; Total Irrigable Acreage; Acreage now Irrigated; Total Number of Farms; Average Acres per Farm; A verage Value Land per Acre; Average Increased Value-1900-1911

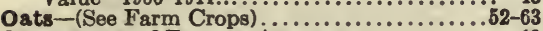

Occupancy of Farms-A verage.............. 13

Miscellaneous Data-Statistical............ 44

People of Oregon....................114-117

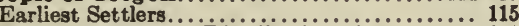

Rural Population-Distribution of......... 116

Their Heritage...................... 111

Peaches-(See Fruits and Vegetables)........71-85

Pears - (See Fruits and Vegetables)...........71-85

Peas-(Field) - Oregon Yield and Prices (1909)

- Compared with Other States............ 54

Population-

Need for Denser.

Rural-Distribution of . . . . . . . . . . . . . . . 116

The People of Oregon ..........................

Potatoes-Yield in Bushels, 10 Year Average and for 1912, as compared with Other States.

Poultry Industry-Article on............... Different Types of Poultry Keeping.......... 87

Poultry and Fruit..................... 94

Seven Oregon Farms-Receipts, Expenses and Capital Invested...............87-88-91

Climatic Conditions..................... 90

Description of ..........................

General Information and Analysis of Stat-

istics...........................80-93

Typical Successful Farms...................124-131

Value Poultry Products (Map).................. 96

Poultry Farming - by Divisions.............36-37

Prunes-(See Fruits and Vegetables) ...........71-85

Publications-List of Issued by the Öregon

State Immigration Commission

................................... Cover)

Pumice Soil-Composition and Description

of ..................... 46-51

Raspberries - (See Fruits and Vegetables).....71-85

Rural Eomes of Oregon-Article on.......125-127

Cost of Dwellings.

Railroads and Navigabie streams (Map)........... 118

Transportation and Communication........117-119

Roports from Farmers-

Number of From Each County............ 11

Sandy Loam Soll-Composition and Description of

selecting th.........................46-48

Selecting a Farm in Orogon............... 35

Best Size of Farm-Cropping Area.......... 37

Examining Prospective Purchase............ 38

Fences, Family Orchards, Etc........... 42

Healthfulness, Marketing Conditions, Libor Supply, Water, Community Conditions...

Physical Character, Climatic Conditions,

Etc...................... 40

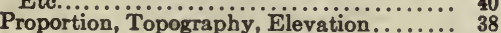

Soils, Natural Vegetation, Etc. ........ 40-48

Valuations, Homestead Lands, Etc....... 43

The Ty pe, Region, Climate, Size, Etc.........35-41

\section{Sheop-}

Average Cost of Wintering

Average Size of Band per Employee......... 23

Cost of Starting into Business............... 23

Distribution of in State $\ldots \ldots \ldots \ldots \ldots \ldots \ldots . . . . .22$

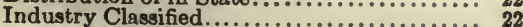

Lambs-What to Feed...................... 23

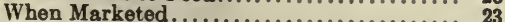

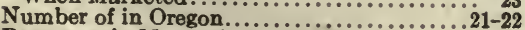

Pasturage in Mountains and Valleys......... 23

Principal Breeds in State.................. 24
Page

Principal Growing Centera.................. 24

Range on National Forest Reserves........... 23

Scope of Range Sheep Industry; A verage

Wool Clip per Head; Cost of Production;

Percent of Increase.................... 22

Spring Lambing in Western Oregon.......... 23

Statistics on ........................ 21

Willamette Valley a Famous Breeding Section. 24

silt Loams-Composition and Description of .46-17

Size of Farms ...................... 75

Social statistics-

Churches and their Influence............. 122

Educational Facilities................... 120

Educational Institutions, Location of (Map).. 121

Postal Service and Telephone.............. 119

Railroads and Navigable Streams (Map)..... 118

Rural Organizations...................... 123

Summary........................... 123

Solls of Oregon ......................46-52

Chief Types of .......................... 46

Chemical and Physical Analyse of ...........40-46

Climate and Relation to................41-42

Judging Fertility of ..................... $39-40$

Examining for Fertility................... 40

Relation of to Farm Value..............39-41

Composition and Deseription of "Adobe","

"Alkali" "Granitic" "Pumice", "Marsh"

"Sandy" and "Silt" soils and loams-46-52

State Immigration Office-Address of .

St..................... (Inside Back Cover)

Of Book Based on Averages.

Statistical Data

Acreage, Average of Farms Reporting......... 99

Alfalfa, Average Acreage, Price, Yield, Value,

Etc.-by Divisions.

Agricultural Products in Oregon, year 1012.. 33

Agriculture Taught in Schools.............. 118

Associations for Social Conditions.......... 120

Average Acres Irrigated $. . \ldots \ldots \ldots \ldots \ldots \ldots, \ldots$

Average Amount Manure Used............... 4

Average Cost of Clearing Land............ 44

Average Crop Sales per Acre............... 44

Average Depth of Wells................. 44

Average Number of Work Horses per farm.... 4

Average Percent Using Irrigation............ 44

Average Percent Using Rotation............. 4

A verage Rental for General Farms............ 4

Average Wages Farm Labor............... 45

Bank Accounts............................ 108

Barley-Average Acreage, Price, Yield, V̌lue.

Etc. - by Divisions...................... 67

Bee Oulture.............................. 97

Best Size of Farm-C̈ropping Area, for Diffor-

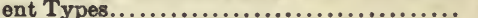

Business Methods-Reports Showing Bank Accounts; Records Kept, Etc.............. 106

Butter Making, by Women at Home......... 116

Capital Invested, Average.................. 102

Cattlo-by Divisions...................... 15

Breeds of-by Divisions

Churches, Influence of Increasing........... 117

Classification of Reports.....................

Climatological Data, Summary of for a Period

of Years........................... 68

Elevation, Precipitation, Evaporation, $\mathrm{Hu}$ midity, Frost (A verage Date of), Growing Seasons, Temperatures, Wind Velo-

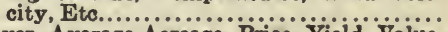

Clover, Average Acreage, Price, Yiold, Value,

Etc.-by Divisions.....................

Crope-Counties Leading in Production of

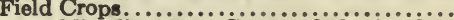

Crops-Miscellaneous, Grown Only in Certain Regions. ............................. 61

Crops-Oregon Yieïd and Prices Compared s

with Other States.....................53-54 


\section{INDEX-Continued.}

Crops-Total Production and Acreage- Pago Divisions $-1909 \ldots \ldots \ldots \ldots \ldots \ldots \ldots \ldots . .65$ Dairy Cows-Number of in Proportion to Population and Area of State............. 25 Breeds of Cattle...................... 30 Butter Fat Prices........................ 32 Compared With Other Dairy States....... 26 Cream Separators-Number and Kind ofby Divisions.

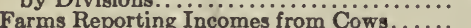

Labor and Wages................ 29

Number and Value of Cows and Heifersby Divisions.

Size of Herds and A verage Value per Cow.

.

ruits and Vegetables-State Averages in Production, Yield, Price and Income per Acre 71-74-78-79-80-81-82-83

General Statistics on Agriculture by Divisions - Number of Reports; Average Years on Farms; Years Experience as Farmers; Average Acreage Operated; Men and Horses Required to Operate Farms; Opportunities for Work, by Classification of Labor; Average Depth of Wells; Number of Rural Telephones.

Grain-Average Acreage, Price, Yield, Value, Etc-by Divisions

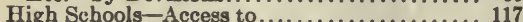

High Schools-Location of (Map).............. 117

Hogs-by Divisions........................ 17

Hogs-Production.......................... 54

Horses-by Divisions................... 19

Implements and Machinery-Average Value

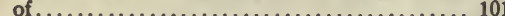

Income-Average Gross. .................. 101

Income-Average Family.................... 103

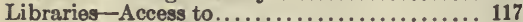

Livestock-Average Value of ............... 100

Miscellaneous Data (Statistical) ............. 41-45

Oats-Average Acreage, Price, Yield, Value, Etc.-by Divisions.

Occupation of Lands in Ö....................... 43

Organizations for Material Improvements..... 120

Percentage of Different Types of Farms Examined in the Agricultural Survey........... \&

Potatoes-Average Acreage, Price, Yield, Value, Etc.-by Divisions. ............ 57

Poultry Industry - Seven Oregon Farms, Showing Different Types.

Recoipts, Expenses, Capital Invested E..... $85-80$

Profit-Average Rate of, Including Family

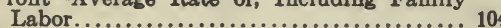

Profit-Percent of ............................... 105
Pecorls Kept........................ Page

Rural Free Delivery........................ 116

Sheop-by Divisions......................... 21

Societies for Social Intercourse $\ldots \ldots \ldots \ldots \ldots, 120$

Societies for Women........................ 120

Social Statistıcs. . .....................116-120

Butter Making by Women at Home, Nationality, Rural Free Delivery, Rural Telephones.

Soil Types-Composition of .................... 46

Soil Types, of Oregon....................... 46

Statistics Based on A versges................... 12

Telephones-Rural .................... 116

Temperature and Rainfall-Mean Monthly-

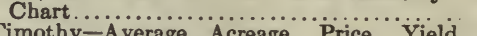

Timothy-A verage Acreage, Price, Yield,
Value, Etc - by Divisions

Typical Sucressful Farm (a Summary)......124-131

Value of Farms and Farm Property........ 107

Wheat-Srring, A verage Acreage, Price, Yield, Value, Etc - by Divisions.

Wheat-Winter, Average Acreage, Price, Yield, Value, Etc - by Divisions.

Wild Hay-Average Acreage, Price, Yield, Value, Etc. - by Divisions.................

Study This Book.

Telephone, Rural-by Divisions.................... 13 Topography-Map of State.................. Transportation and Communication....... 11,

Railroads and Navigable Streams (Map)....... 118 Truck Gardening in Oregon $\ldots \ldots \ldots \ldots . .7$ t Truck and Small Fruit FarmingBy Divisiuns. ...................... Types of Solls-Composition and Description of.

46-51

Typical Successful Farms-(Article on)..124-131

Blue Mountain Division.................. 129

Central Uregon................................ 130

Coast Division

Columbia Basin ........................... 128

Southern Oregon Division.................... 127

Willamette Valley

Value and Price of Farm Iands........ 43-74-75 Vegetables-

State Average in Production, Value,Etc..... 74

Wages and Labor-With and Without Buard-

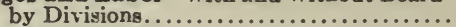

On Dairy Farms ........................ 44

Crop Sales, A verage-by Divisions........... 44

Farm Labor-Demand for ................ 131

Walnuts-Growing of in Oregon................. 73

Wolls-A verage Depth in State-by Divisions. 13-44 Wheat-(See Farm Crops)...............52-63 Work-Opportunities for-Carpenters, Blacksmiths and Masons.

\section{READ and STUDY the Subject Matter.}

The subject matter of this bulletin is not intended for hurried or careless reading. The idea of the writers throughout has been to compress the greatest possible amount of information into the smallest possible space. Every sentence carries an important fact for the guidance of the newcomer seeking accurate information regarding Oregon from the agricultural standpoint. Every statement is a conclusion, "boiled down", drawn from the observation and experience of men who have made a long study of their special lines and know the agricultural conditions and possibilities of Oregon in detail. It has boen their effort to make their statements conservative. They have not attempted to tell the newcomer how to farm his lands; but, rather, to give him facts relative to the present production in the state and information such as will aid him in GETTING STARTED RIGHT, so that he may aroid making mistakes in selecting his field for work and have the best opportunity for success. The reader who is truly interested in "Oregon's Opportunity" should not merely READ these discussions, but should STUDY them if he wishes to more clearly understand the facts contained herein. 


\section{OREGON STATE IMMIGRATION}

COIMMISSION:

THOMAS C. BURKE, President

MARSHALL N. DANA, Secretary

JOHN M. SCOTT

W. E. COMAN

F. W. LONEGREN

STATE IMIMIGRATION AGENT:

C. C. CHAPMAN

For further information address:

Oregon State Immigration Office

Commercial Club Building

Portland, Oregon 


\section{THE OREGON FARMER}

WHAT HE HAS ACCOMPLISHED IN EVERY PART OF THE STATE

A Preliminary Agricultural Survey Under the Direction of an Advisory Committee

From the Faculty of

Oregon Agricultural College CORVALLIS

Conducted by

Oregon Statistical Bureau

J. A. BEXELL, Director

E. B. Lemon, Assistant Statistician

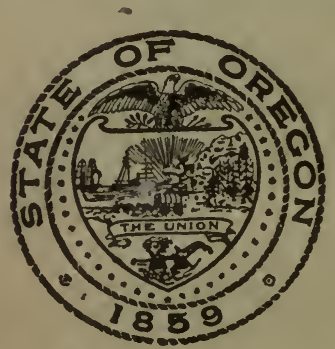

1913

Published by

Oregon State Immigration Commission

C. C. CHAPMAN

State Immigration Agent

PORTLAND, OREGON 


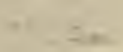

3 


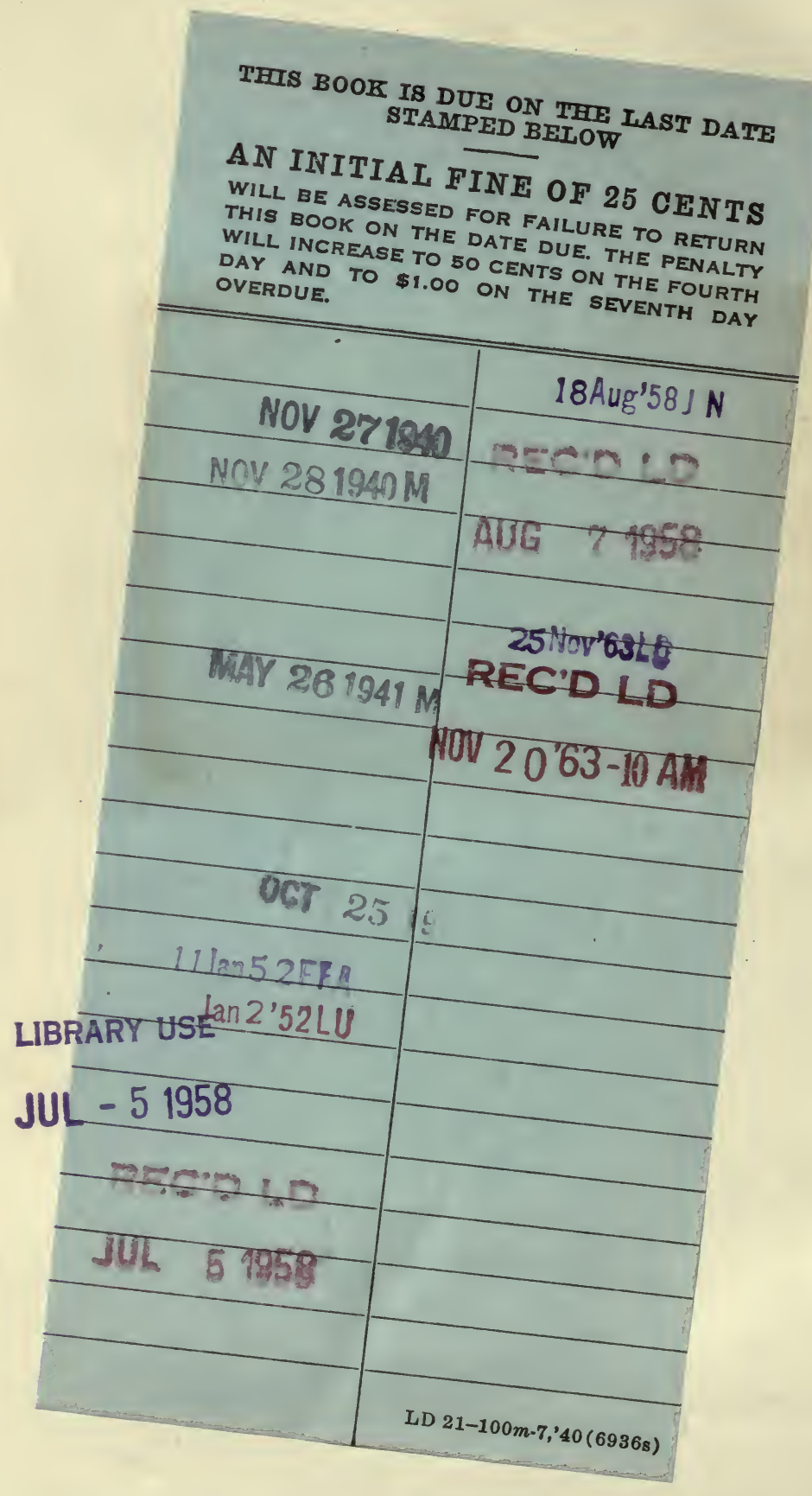




\section{YC 67764}

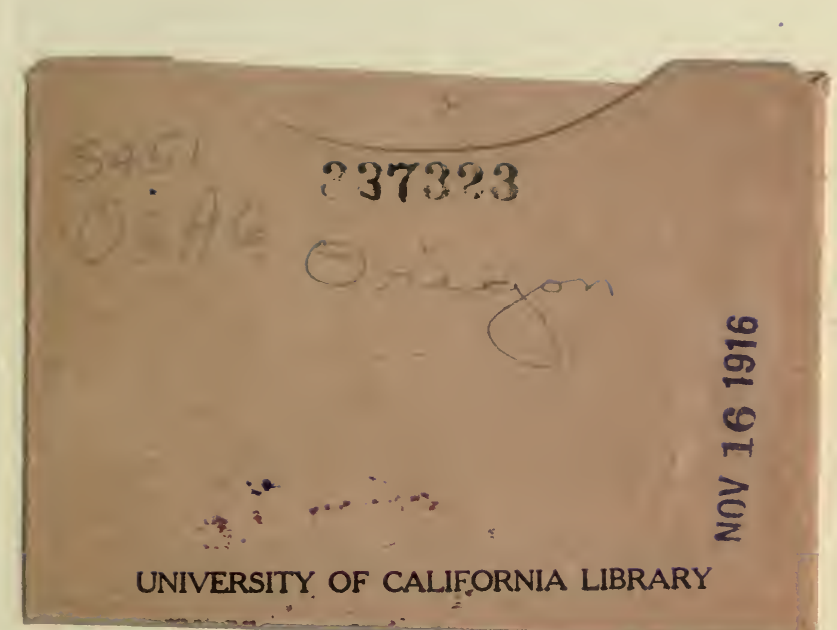

\section{UNIVERSITY OF CALIF,ORNIA LIBRARY}


